\title{
POWDER RIVER BASIN COALBED Methane DeVELOPMENT AND ProducEd WATER MANAGEMENT STUdY
}

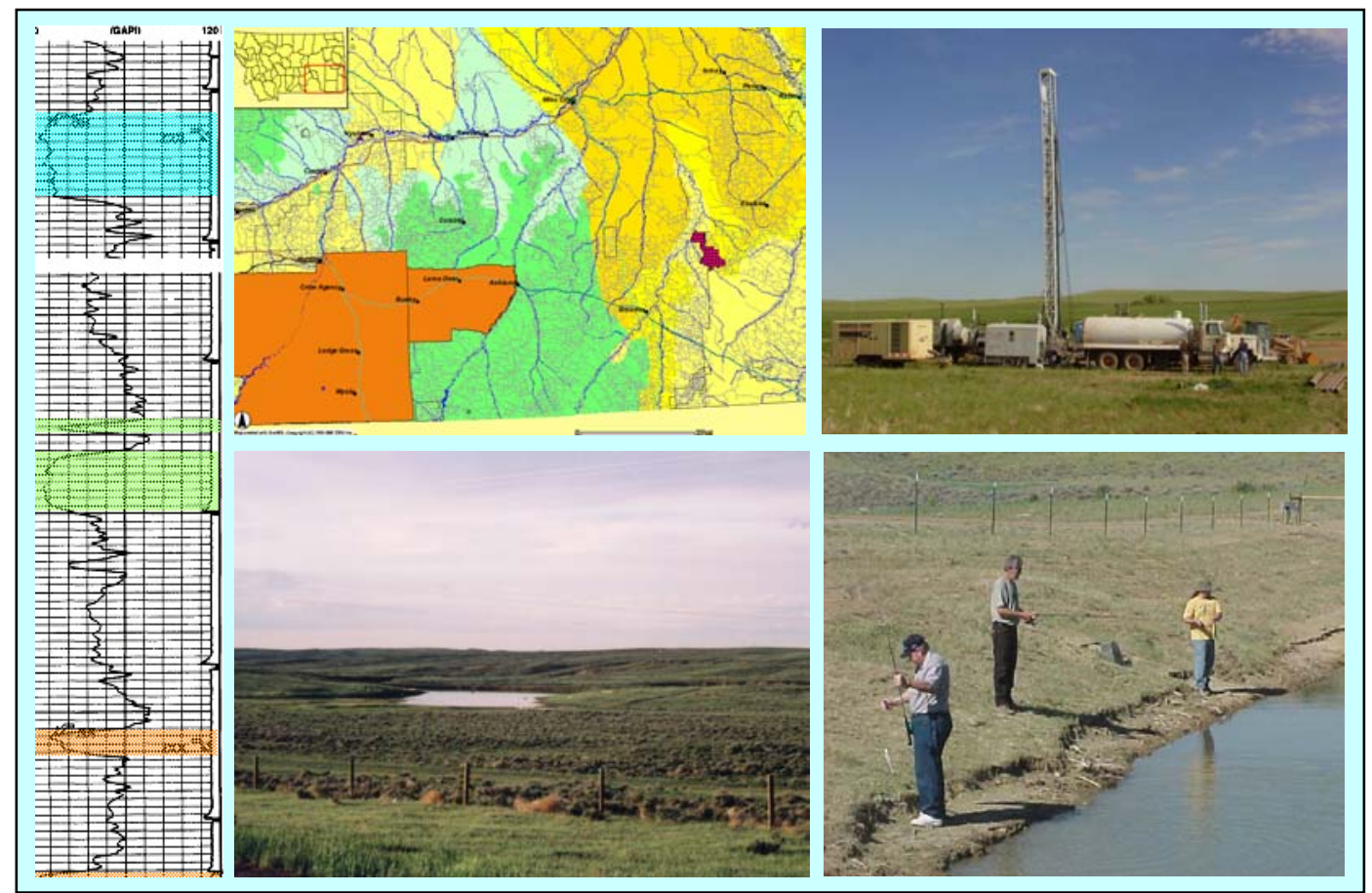

\section{U.S. Department of Energy}

\section{Office of Fossil Energy}

$$
\text { and }
$$




\section{DISCLAIMER}

This report was prepared as an account of work sponsored by an agency of the United States Government. Neither the United States Government nor any agency thereof, nor any of their employees, makes any warranty, express or implied, or assumes any legal liability or responsibility for the accuracy, completeness, or usefulness of any information, apparatus, product, or process disclosed, or represents that its use would not infringe privately owned rights. Reference therein to any specific commercial product, process, or service by trade name, trademark, manufacturer, or otherwise does not necessarily constitute or imply its endorsement, recommendation, or favoring by the United States Government or any agency thereof. The views and opinions of authors expressed therein do not necessarily state or reflect those of the United States Government or any agency thereof. 


\section{Powder River Basin Coalbed Methane Development and Produced Water Management Study}

Prepared for:

U.S. Department of Energy

Office of Fossil Energy and

National Energy Technology Laboratory

Prepared by:

Advanced Resources International, Inc.

November 2002 



\section{DEPARTMENT OF ENERGY}

\section{FOREWORD}

The President's National Energy Policy Plan estimates that over the next 20 years annual natural gas consumption will increase by 50 percent, from approximately 20 to 31 trillion cubic feet (Tcf). To meet this growing demand for natural gas, the Plan concludes that we will have to fully develop, in an environmentally sensitive manner, our nation's economically recoverable natural gas resources.

Natural gas produced from coal, commonly referred to as coalbed methane (CBM), constitutes 7.5 percent of total annual domestic natural gas production. In 2000, about 1.4 Tcf of coalbed methane was produced in the United States. The Powder River Basin, located in northeastern Wyoming and southeastern Montana, is the nation's fastest growing source of coalbed methane.

In the next 10 years, natural gas development in the Powder River Basin is expected to increase dramatically. As many as 39,000 additional wells will be drilled with 23,900 of these being on Federal lands. Because of this increased drilling activity, the Department of the Interior, Bureau of Land Management (BLM), must prepare Environmental Impact Statements (EIS's) evaluating the environmental impacts associated with drilling activities in the region. BLM issued draft Wyoming and Montana EIS's for comment in January and February, 2002, and expects to have both EIS's completed in February, 2003. In a related matter, the U.S. Environmental Protection Agency (EPA Region 8) is conducting a study of Best Professional Judgment (BPJ) general permit requirements for produced water on Native American lands in the region. This study will be completed in December, 2002.

The BLM EIS's and the EPA Region 8 BPJ study (and possible follow-on actions) will have a significant impact on the development of natural gas resources in the Powder River Basin. Recognizing this, in April, 2002, the U.S. Department of Energy (DOE), Office of Fossil Energy, through its National Energy Technology Laboratory, contracted with Advanced Resources International, Inc. to analyze the basin's geology and underlying coalbed methane resources, estimate water production rates associated with coalbed methane development, and evaluate the costs, feasibility, and impacts of coalbed methane produced water disposal practices. BLM and EPA cooperated with DOE on this study, realizing that this information would be useful to them in their efforts to develop environmental policies and procedures that promote Powder River Basin coalbed methane development while protecting the basin's unique ecosystem.

The present study, Powder River Basin Coalbed Methane Development and Produced Water Management Study, projects that the Powder River Basin contains a considerably larger volume of coalbed methane resources than previously estimated. There is currently a range of resource 
estimates for the Powder River Basin from Federal, State, and industry organizations, varying by almost a factor of five. For example, DOE, BLM, and the U.S. Geological Survey all have current estimates for the amount of recoverable coalbed methane in this basin ranging from 8 Tcf to 39 Tcf. The differences stem from employing alternative methodologies, different geologic models, and different assumptions. When calculating a quantity as uncertain as undiscovered recoverable natural gas resources, such differences are to be expected and even encouraged, as they lead to further scientific investigation and interagency cooperation that increases the state of knowledge about our Nation's energy resources. In addition, each source develops its estimates for different purposes, and this also leads to the use of different approaches. Federal agencies are working together to refine our understanding of the coal bed methane resources of this Basin, and we expect, therefore, that estimates of recoverable natural gas resources in the Powder River Basin will continue to change over time.

In addition, the study projects that recovering these resources will require fewer wells than those projected in the BLM EIS's. The study also reveals that the amount of water associated with coalbed methane production in the Powder River Basin is substantially less than previously estimated. Nevertheless, the study concludes that development of the basin's coalbed methane resources will be significantly impacted by the costs and economic feasibility of produced water management practices and requirements. The study outlines alternative water disposal options, clearly identifies their costs, and makes a compelling argument that requiring more costly methods of produced water management will substantially reduce the amount of economically recoverable Powder River Basin coalbed methane.

Review comments on the study by representatives of BLM, EPA, and State officials from Wyoming and Montana have been overwhelmingly positive. The reviewers expressed their appreciation for DOE support and indicated data contained in the study will be of great value in their efforts to promote responsible, environmentally sound development of the Powder River Basin's coalbed methane resources.

The present study is one of a number of studies sponsored by DOE that examine the issues surrounding coalbed methane development. These include development of best management practices, electronic mapping of environmental and well data, a CBM primer for the public, a handbook for the development and review of environmental documents required for CBM projects, analysis of the options for beneficial use of CBM produced water, and research on technologies for produced water treatment. DOE believes that CBM produced water represents a valuable resource in the Powder River Basin and elsewhere in the arid Western U.S., and that it can be, and is, managed with no significant adverse environmental impacts. Currently, this water is used for livestock and wildlife watering, irrigation, to maintain stream flows, and in municipal aquifer recharge. All discharges of this water are permitted and meet State and Federal standards. Additional beneficial uses are being studied.

For more information about DOE oil and natural gas environmental projects visit the Office of Fossil Energy website at www.fe.doe.gov/oil_gas/environment or contact Peter Lagiovane at: 202-586-8116. 


\section{ACKNOWLEDGMENTS}

This study was conducted by Advanced Resources International, Inc. (ARI), located in Arlington, Virginia, for the U.S. Department of Energy (DOE) Office of Fossil Energy, located in Washington, D.C., and the National Energy Technology Laboratory (NETL), with locations in Morgantown, West Virginia, Pittsburgh, Pennsylvania, and Tulsa, Oklahoma. The principal investigator at ARI was Vello Kuuskraa. Other ARI staff contributing to this effort included A. David Decker, Brian T. Kuck, Greg J. Bank and Joyce A. Frank. The contractor's effort was overseen by NETL's Strategic Center for Natural Gas. The Center's mission includes strategic planning and policy support, focused on creating a balanced portfolio of DOE natural gas research and development initiatives and policy analyses to support more informed government decision making. The Strategic Center for Natural Gas project manager for this analysis was John Duda. Other DOE staff contributing to the effort included H. William Hochheiser and Peter Lagiovane of the Office of Fossil Energy, Office of Natural Gas and Petroleum Technology, and William Lawson and John Ford of the National Petroleum Technology Office. The Department extends its appreciation to those companies operating in the Powder River Basin, and staff of the Department of the Interior, Environmental Protection Agency, and Wyoming and Montana State agencies who provided the technical input and assistance that enabled DOE to improve the scope and quality of the analysis. 



\section{TECHNICAL PREFACE}

Coalbed methane resources throughout the entire Powder River Basin were reviewed in this analysis. The study was conducted at the township level, and as with all assessments conducted at such a broad level, readers must recognize and understand the limitations and appropriate use of the results. Raw and derived data provided in this report will not generally apply to any specific location. The coal geology in the basin is complex, which makes correlation with individual seams difficult at times.

Although more than 12,000 wells have been drilled to date, large areas of the Powder River Basin remain relatively undeveloped. The lack of data obviously introduces uncertainty and increases variability. Proxies and analogs were used in the analysis out of necessity, though these were always based on sound reasoning. Future development in the basin will make new data and interpretations available, which will lead to a more complete description of the coals and their fluid flow properties, and refined estimates of natural gas and water production rates and cumulative recoveries.

Throughout the course of the study, critical data assumptions and relationships regarding gas content, methane adsorption isotherms, and reservoir pressure were the topics of much discussion with reviewers. A summary of these discussion topics is provided as an appendix. Water influx was not modeled although it is acknowledged that this phenomenon may occur in some settings.

As with any resource assessment, technical and economic results are the product of the assumptions and methodology used. In this study, key assumptions as well as cost and price data, and economic parameters are presented to fully inform readers. Note that many quantities shown in various tables have been subject to rounding; therefore, aggregation of basic and intermediate quantities may differ from the values shown. 



\section{TABLE OF CONTENTS}

$\underline{\text { Page }}$

1.0 STUDY PURPOSE, APPROACH AND FINDINGS $\ldots \ldots \ldots \ldots \ldots \ldots \ldots \ldots .1-1$

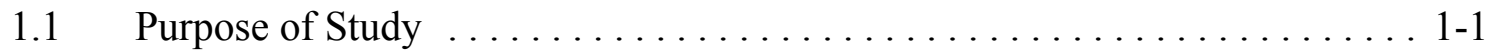

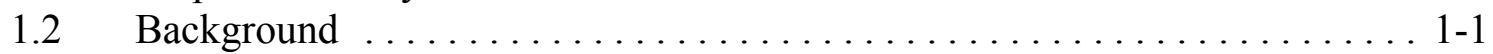

1.3 Partitioning the Powder River Basin $\ldots \ldots \ldots \ldots \ldots \ldots \ldots \ldots \ldots \ldots . . \ldots \ldots$

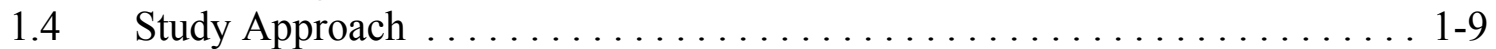

1.5 Summary of Findings and Impacts $\ldots \ldots \ldots \ldots \ldots \ldots \ldots \ldots \ldots \ldots \ldots \ldots \ldots \ldots$

2.0 GEOLOGIC SETTING AND RESERVOIR PROPERTIES $\ldots \ldots \ldots \ldots \ldots \ldots .2-1$

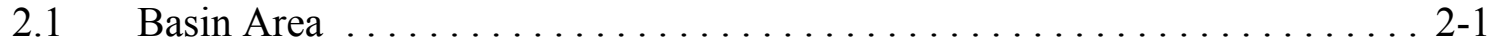

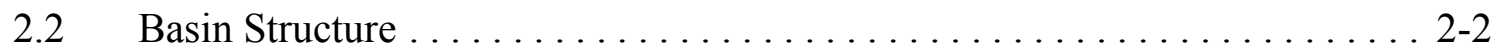

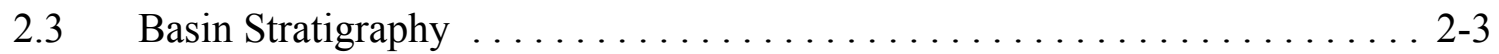

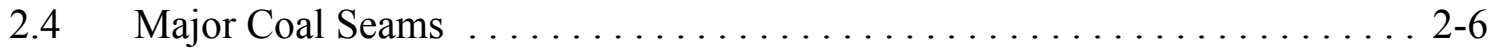

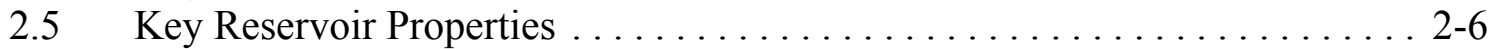

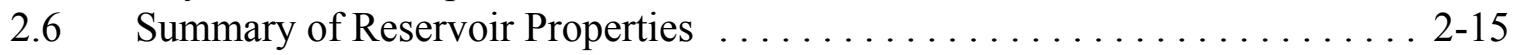

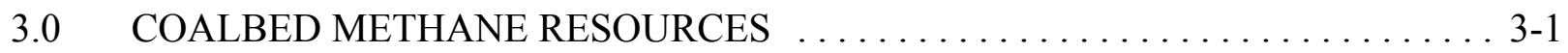

$3.1 \quad$ Summary $\ldots \ldots \ldots \ldots \ldots \ldots \ldots \ldots \ldots \ldots \ldots \ldots \ldots \ldots \ldots \ldots \ldots \ldots \ldots \ldots, 1$

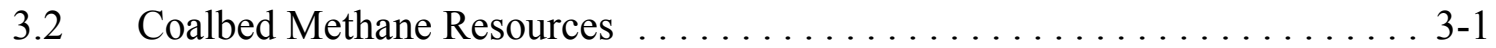

3.3 In-Place and Technically Recoverable PRB CBM Resources, by Partition . . 3-3

3.4 Estimating Gas and Water Production $\ldots \ldots \ldots \ldots \ldots \ldots \ldots \ldots \ldots \ldots \ldots$

4.0 COSTS OF PRB CBM DEVELOPMENT $\ldots \ldots \ldots \ldots \ldots \ldots \ldots \ldots \ldots \ldots . \ldots .4 . \ldots \ldots$

$4.1 \quad$ Basic Cost Model . . . . . . . . . . . . . . . . . . . . . . . . . 4 4-1

4.2 Discussion of CBM Development Capital Costs . . . . . . . . . . . 4-5

4.3 Discussion of CBM Well O\&M Costs ..................... 4-9

5.0 ECONOMICS OF PRB CBM UNDER ALTERNATIVE WATER DISPOSAL

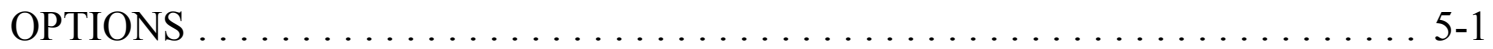

$5.1 \quad$ Summary $\ldots \ldots \ldots \ldots \ldots \ldots \ldots \ldots \ldots \ldots \ldots \ldots \ldots \ldots \ldots \ldots \ldots \ldots \ldots \ldots \ldots \ldots, 1$

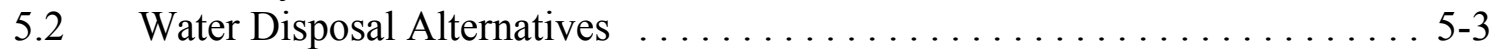

5.3 Costs of Water Disposal Alternatives . . . . . . . . . . . . . . . . . 5-4

5.4 Discussion of Water Disposal Capital and O\&M Costs . . . . . . . . . . . 5-6

5.5 Detailed Economic Analyses of Water Management Options . . . . . . . . 5 5-10

6.0 PRESENTATION OF RESULTS BY BASIN PARTITION $\ldots \ldots \ldots \ldots \ldots \ldots .6-1$

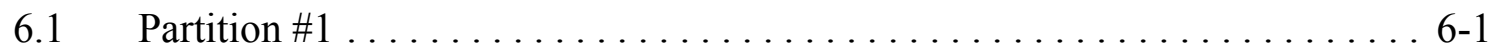

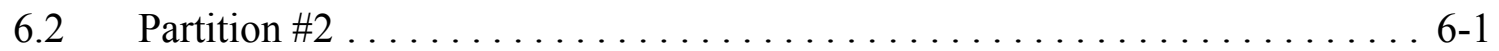

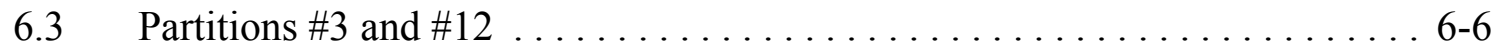

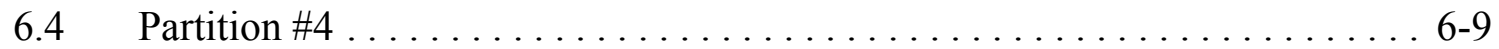

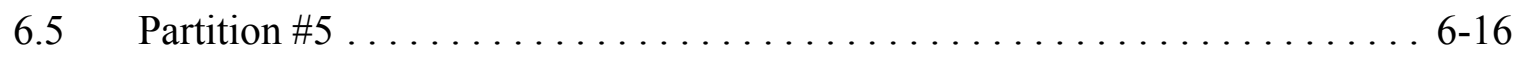




\section{TABLE OF CONTENTS}

(Continued)

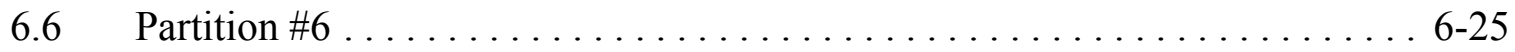

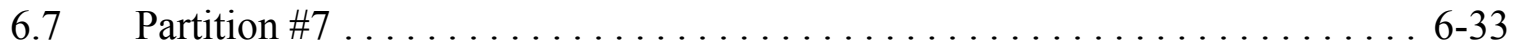

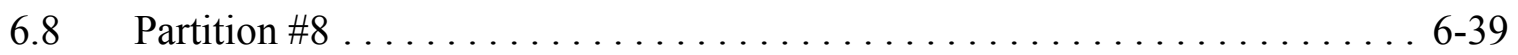

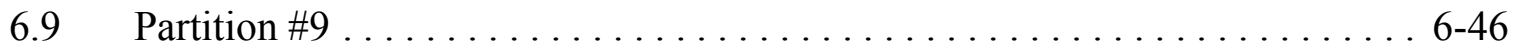

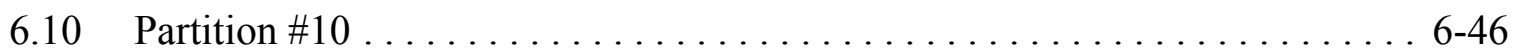

6.11 Partition $\# 11 \ldots \ldots \ldots \ldots \ldots \ldots \ldots \ldots \ldots \ldots \ldots \ldots \ldots . \ldots \ldots \ldots$

$\underline{\text { Figures }}$

Figure 1-1. Powder River Basin, Growth of Coalbed Methane Production . . . . . . . . . 1-2

Figure 1-2. Powder River Basin, Growth in CBM Water Production . . . . . . . . . . . 1-2

Figure 1-3. CBM Water/Gas Production Ratio . . . . . . . . . . . . . . . . 1-3

Figure 1-4. CBM Water Production Per Well $\ldots \ldots \ldots \ldots \ldots \ldots \ldots \ldots \ldots \ldots \ldots \ldots$

Figure 1-5. Powder River Basin CBM Partitions . . . . . . . . . . . . . . . . . . 1-5

Figure 1-6. Extent of CBM Drilling Map, Partition \#4, Anderson Coal Seam Wells . . . . 1-6

Figure 1-7. Extent of CBM Drilling Map, Partition \#4, Canyon Coal Seam Wells . . . . . . 1-7

Figure 1-8. Extent of CBM Drilling Map, Partition \#4, Wyodak Coal Seam Wells . . . . . 1-8

Figure 2-1. Coal Basins of Wyoming . . . . . . . . . . . . . . . . . . . 2-1

Figure 2-2. Center of Powder River Basin Coalbed Methane Activity . . . . . . . . . . . 2-2

Figure 2-3. Regional Structure and Tectonic Map of the Powder River Basin . . . . . . . 2-3

Figure 2-4. Regional Cross Section of the Powder River Basin . . . . . . . . . . . . . . . . 2-4

Figure 2-5. Upper Cretaceous and Tertiary Stratigraphic Chart for Powder River Basin . . . 2-4

Figure 2-6. Coal Bearing Units of the Tongue River Member of the Fort Union

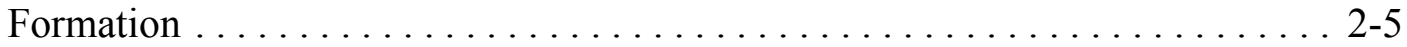

Figure 2-7. Simplified Representation of Fort Union Coalbeds Near Gillette, in Campbell County, Wyoming . . . . . . . . . . . . . . 2-7

Figure 2-8. Sample Log Upper Fort Union Coals in Partition \#4 . . . . . . . . . . . . . . . . 2-8

Figure 2-9. Coal Correlation Diagram for Fort Union and Wasatch Formation, Powder River Basin, Wyoming . . . . . . . . . . . . . . . . . . . . 2-9

Figure 2-10. Cross-Section Showing Lateral Variation of Coalbeds in the Wyodak Coal Zone . . . . . . . . . . . . . . . . . . . . . . . . . . . . . 2 2-11

Figure 2-11. Regional Pressure Gradient . . . . . . . . . . . . . . . . . 2-11

Figure 2-12. Reservoir Pressure Profile Used for PRB Study . . . . . . . . . . . . . . . 2-12

Figure 2-13. Gas Content Isotherm Used for Powder River Coalbed Methane . . . . . . . . 2-13

Figure 2-14. Average Synthesized Adsorption Isotherm for 41 Coal Samples From the

PRB, Based on a Compilation of Data From Public and Private Sources . . . . 2-13

Figure 3-1. Wyodak Coal Seam Time Zero Plot . . . . . . . . . . . . . . . . . 3-9

Figure 3-2. Wyodak Type Well History Match . . . . . . . . . . . . . . . . . . . 3-10

Figure 3-3. 10-Year Simulation of Gas and Water Production for Wyodak Type Well ... 3-11 


\section{TABLE OF CONTENTS}

(Continued)

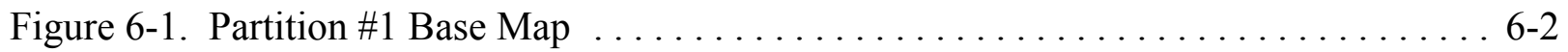

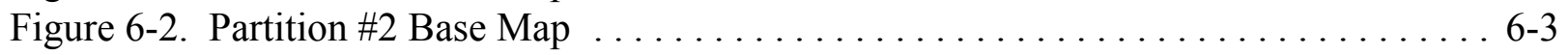

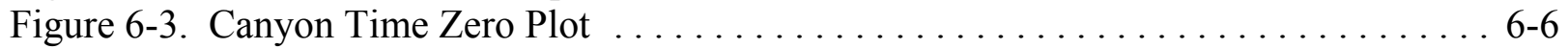

Figure 6-4. Wyodak Time Zero Plot $\ldots \ldots \ldots \ldots \ldots \ldots \ldots \ldots \ldots \ldots \ldots \ldots .6 .6 \ldots \ldots \ldots$

Figure 6-5. Partition \#3 Base Map $\ldots \ldots \ldots \ldots \ldots \ldots \ldots \ldots \ldots \ldots \ldots \ldots \ldots .6 .11$

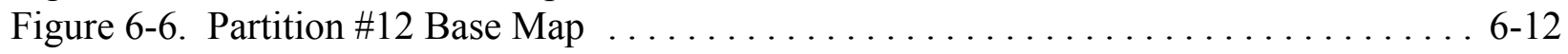

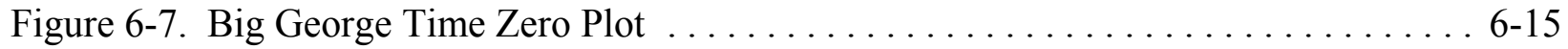

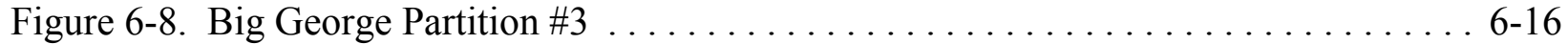

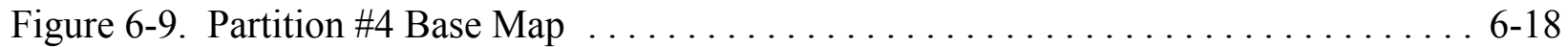

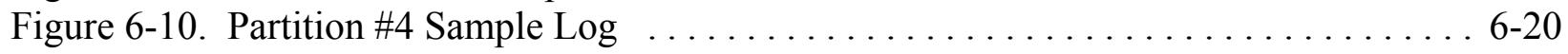

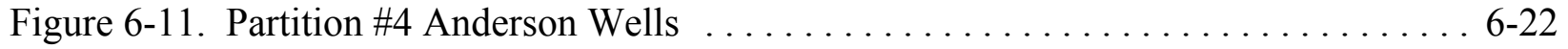

Figure 6-12. Anderson Time Zero Plot ............................ 6-23

Figure 6-13. Anderson Type Well, Partition $\# 4 \ldots \ldots \ldots \ldots \ldots \ldots \ldots \ldots \ldots \ldots \ldots .6 .24$

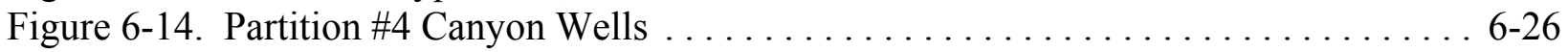

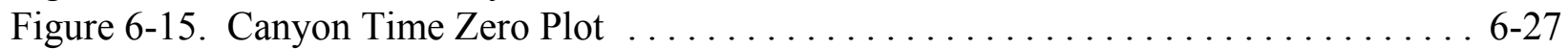

Figure 6-16. Canyon Type Well, Partition \#4 $\ldots \ldots \ldots \ldots \ldots \ldots \ldots \ldots \ldots \ldots \ldots \ldots .6 .6 \ldots \ldots$

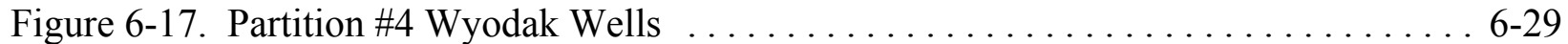

Figure 6-18. Wyodak Time Zero Plot $\ldots \ldots \ldots \ldots \ldots \ldots \ldots \ldots \ldots \ldots \ldots \ldots \ldots \ldots \ldots \ldots$

Figure 6-19. Wyodak Type Well, Partition \#4 ................... 6-32

Figure 6-20. Partition \#4 Cook Wells . . . . . . . . . . . . . . . . . . . . . 6-33

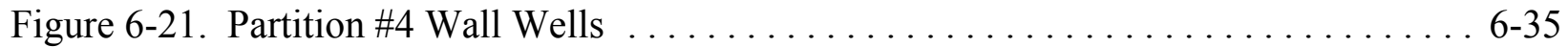

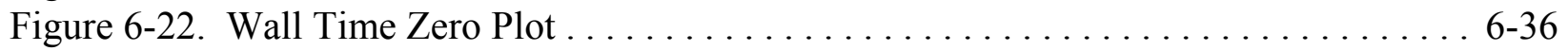

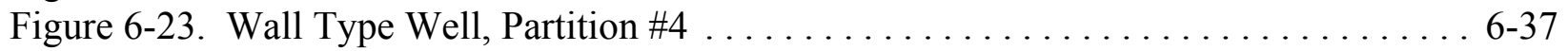

Figure 6-24. Partition \#4 Pawnee Wells . . . . . . . . . . . . . . . . . . . . . . . 6-39

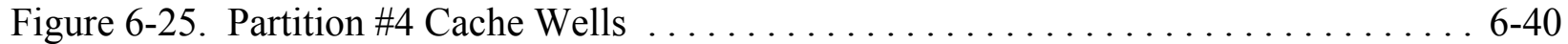

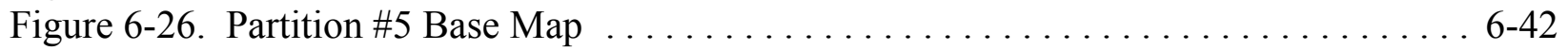

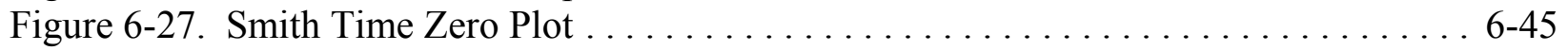

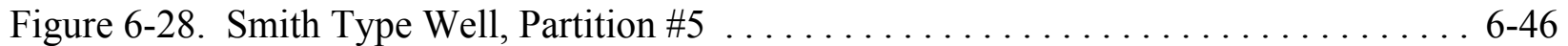

Figure 6-29. Anderson Time Zero Plot .......................... 6-48

Figure 6-30. Canyon Time Zero Plot $\ldots \ldots \ldots \ldots \ldots \ldots \ldots \ldots \ldots \ldots \ldots \ldots \ldots . \ldots \ldots$

Figure 6-31. Big George Coal Seam - Aggregate ...................... 6-52

Figure 6-32. Big George Coal Seam Well Location and Elevation Map, Partition \#5 . . . 6 6-53

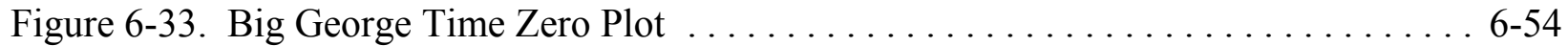

Figure 6-34. Big George Type Well Partition $\# 5 \ldots \ldots \ldots \ldots \ldots \ldots \ldots \ldots \ldots \ldots \ldots .6 \ldots \ldots \ldots$

Figure 6-35. Wyodak Time Zero Plot . . . . . . . . . . . . . . . . . . . . 6-57

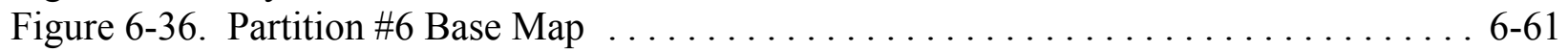

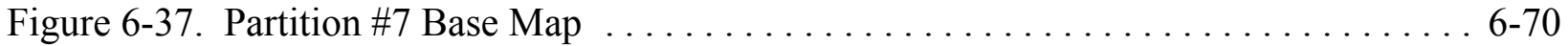

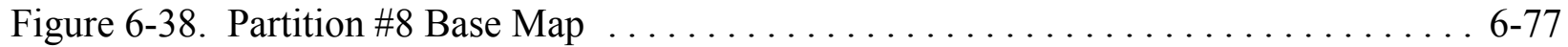

Figure 6-39. Anderson Time Zero Plot . . . . . . . . . . . . . . . . . . . 6-80

Figure 6-40. Anderson Type Well, Partition $\# 8 \ldots \ldots \ldots \ldots \ldots \ldots \ldots \ldots \ldots \ldots .6 .61$ 


\section{TABLE OF CONTENTS}

(Continued)

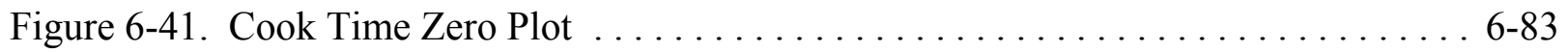

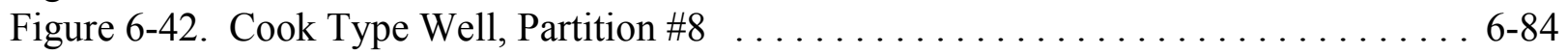

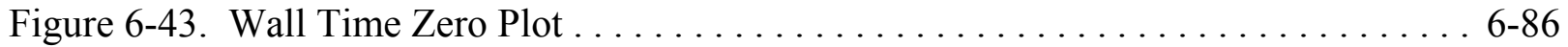

Figure 6-44. Wall Type Well, Partition $\# 8 \ldots \ldots \ldots \ldots \ldots \ldots \ldots \ldots \ldots \ldots \ldots$. . . . . . . . . . . . . .

Figure 6-45. Pawnee Time Zero Plot . . . . . . . . . . . . . . . . . . . . . . 6-89

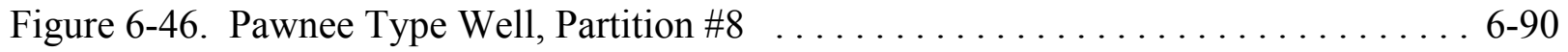

Figure 6-47. Partition \#9 Base Map . . . . . . . . . . . . . . . . . . . . 6-93

Figure 6-48. Partition \#10 Base Map . . . . . . . . . . . . . . . . . . . . . . . 6-94

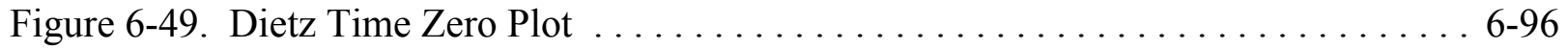

Figure 6-50. Monarch Time Zero Plot . . . . . . . . . . . . . . . . . . . 6-98

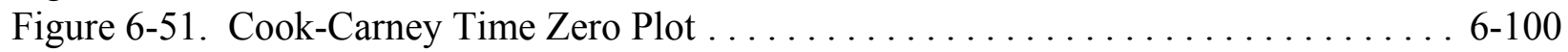

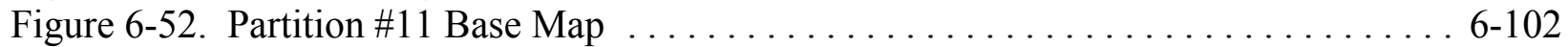

Figure 6-53. Dietz (Anderson) Time Zero Plot . . . . . . . . . . . . . . . . . 6-103

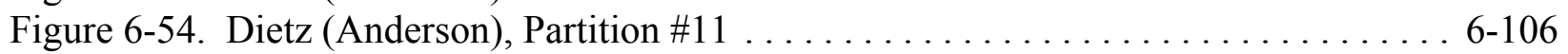

Figure 6-55. Monarch (Canyon) Time Zero Plot . . . . . . . . . . . . . . . . 6 6-107

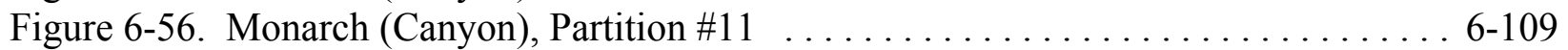

Figure 6-57. Carney (Cook) Time Zero Plot . . . . . . . . . . . . . . . . . . . 6-110

Figure 6-58. Carney (Cook), Partition $\# 11 \ldots \ldots \ldots \ldots \ldots \ldots \ldots \ldots \ldots \ldots \ldots \ldots$. . . . . . . . . . . . . .

Figure A-1. Gas Content Isotherm Used for Powder River Coalbed Methane ........ A-3

Figure A-2. Average Synthesized Adsorption Isotherm for 41 Coal Samples From the PRB, Based on a Compilation of Data From Public and Private Sources . . . . A-3

Figure A-3. Variation in Sorption Capacity with Temperature, Dietz \#3 Coal ... . . . . . A-5

Figure A-4. Comparison of Bustin and Downey Adsorption Iostherm for Dietz \#3 Coal with Advanced Resources Adsorption Isotherm for PRB Coals A-5

Figure A-5. Wyodak Time Zero Well Data . . . . . . . . . . . . . . . . A-7

Figure A-6. History Match Wyodak Type Well w/Free Gas . . . . . . . . . . . . . . . A-7

Figure A-7. Reservoir Simulation of Wyodak Type Well w/No Free Gas . . . . . . . . . . A A-8

Figure A-8. Reservoir Simulation of Wyodak Type Well w/23\% Gas Undersaturation . . . A-8

Figure A-9. Reservoir Simulation of Wyodak Type Well w/66\% Gas Undersaturation ... A-9

Figure A-10. Big George Time Zero Well Data . . . . . . . . . . . . . . . A A-10

Figure A-11. History Match Big George Type Well $\ldots \ldots \ldots \ldots \ldots \ldots \ldots \ldots \ldots \ldots$ A-11

Figure A-12. Reservoir Simulation of Big George Type Well w/23\% Gas Undersaturation

$\underline{\text { Tables }}$

Table S-1. Volumes of Economically Recoverable CBM w/Alternative Water

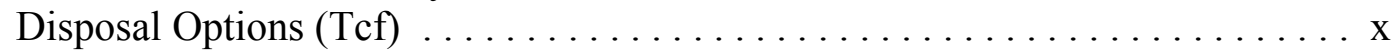

Table S-2. Summary of Impacts from Using Alternative Water Disposal Methods for CBM Produced Water in the PRB ....................

Table 1-1. Reports and Data for Powder River CBM and Water Study . . . . . . . . . . 1-10 


\section{TABLE OF CONTENTS}

(Continued)

Table 1-2. Electronic Data Sources for Powder River CBM and Water Study . . . . . . . 1-12

Table 1-3. Economically Recoverable CBM (Tcf) ....................... 1-14

Table 1-4. Volumes of Economically Recoverable CBM (Tcf) . . . . . . . . . . . . 1-14

Table 1-5. Volumes of CBM Produced Water (Billion Bbls) $\ldots \ldots \ldots \ldots \ldots \ldots \ldots \ldots \ldots . .1-15$

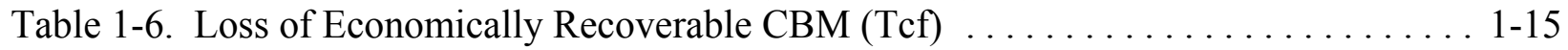

Table 1-7. Loss of Mineral Royalties from CBM (\$MM) .................... 1-16

Table 1-8. Loss of Well Drilling for CBM (\# Wells) . . . . . . . . . . . . . . . . . 1-16

Table 1-9. Loss of Capital Investment for CBM (\$MM) . . . . . . . . . . . . . . . 1-17

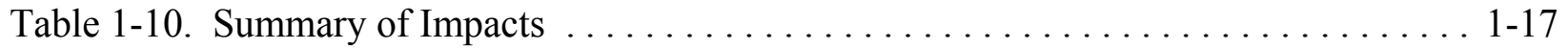

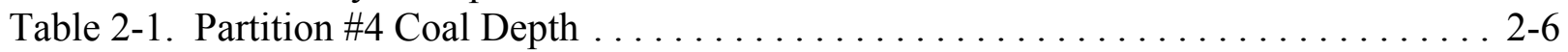

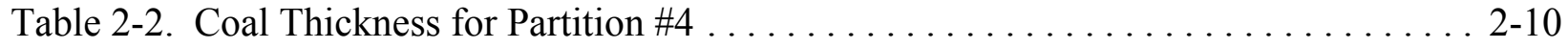

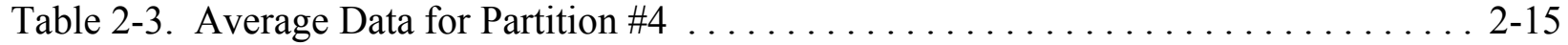

Table 2-4. Key Reservoir Properties for Powder River Basin Coals . . . . . . . . . . . . 2-16

Table 3-1. Gas In-Place for Major PRB Coal Seams (Bcf) $\ldots \ldots \ldots \ldots \ldots \ldots \ldots \ldots . . \ldots \ldots .2$

Table 3-2. Technically Recoverable Resources for Major PRB Coal Seams (Bcf) . . . . . . . 3-3

Table 3-3. In-Place and Technically Recoverable CBM, Partitions \#1 and \#2 ........ 3-4

Table 3-4. In-Place and Technically Recoverable CBM, Partitions \#3 and \#12 . . . . . . . 3-4

Table 3-5. In-Place and Technically Recoverable CBM, Partition \#4 . . . . . . . . . . . . 3-5

Table 3-6. In-Place and Technically Recoverable CBM, Partition $\# 5$. . . . . . . . . . 3-5

Table 3-7. In-Place and Technically Recoverable CBM, Partition \#6 . . . . . . . . . . . 3-6

Table 3-8. In-Place and Technically Recoverable CBM, Partition \#7 . . . . . . . . . . . . 3-6

Table 3-9. In-Place and Technically Recoverable CBM, Partition \#8 . . . . . . . . . . . 3-7

Table 3-10. In-Place and Technically Recoverable CBM, Partition \#9 . . . . . . . . . . 3-7

Table 3-11. In-Place and Technically Recoverable CBM, Partition \#10 . . . . . . . . . . 3-8

Table 3-12. Number and Nature of CBM Wells for History Matching $\ldots \ldots \ldots \ldots \ldots .3-9$

Table 3-13. Summary Results for PRB Coalbed Methane History Matching . . . . . . . . 3-10

Table 3-14. Number of CBM Type Wells for Basin Assessment . . . . . . . . . . . . . . . 3-12

Table 4-1. Capital Costs for PRB CBM Well .......................... 4-2

Table 4-2. O\&M Costs for PRB CBM Well .......................... 4-3

Table 4-3. Capital Costs for Alternate Method of Water Disposal ................ . 4-4

Table 4-4. Sample Tangible and Intangible Costs for Two PRB CBM Wells .......... 4 4-6

Table 4-5. Additional Drilling and Completion Costs for Two PRB CBM Wells ....... . . 4-7

Table 4-6. Pump Replacement Costs . . . . . . . . . . . . . . . . . . . . . . . 4 4-9

Table 5-1. Volumes of Economically Recoverable CBM w/Alternative Water Disposal Options . ........................... 5-2

Table 5-2. Volumes of Economically Recoverable CBM w/Alternative Water Disposal Options . . . . . . . . . . . . . . . . . . . . . . . . . . 5-3

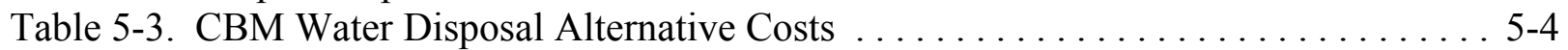

Table 5-4. Capital Costs for Disposal Options ....................... 5-5

Table 5-5. Total Estimated Costs for Deep Disposal . ....................... . 5-5

Table 5-6. Total Capital Costs for Active Water Treatment .................... 5 5 9 


\section{TABLE OF CONTENTS}

(Continued)

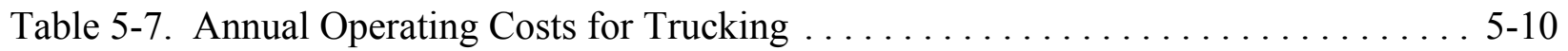

Table 5-8. Assumptions for Discounted Cash Flow Analyses ................ 5-10

Table 5-9. Cashflow Model Surface Discharge ....................... 5-122

Table 6-1. Anderson Coal Seam ................................. 6-2

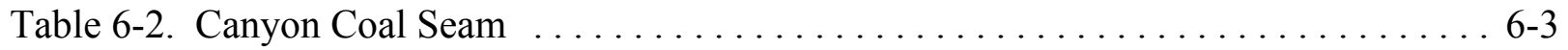

Table 6-3. Wyodak Coal Seam ................................ 6-4

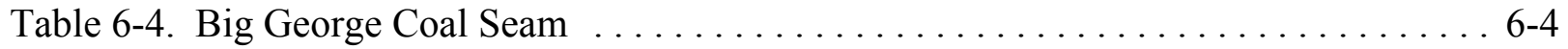

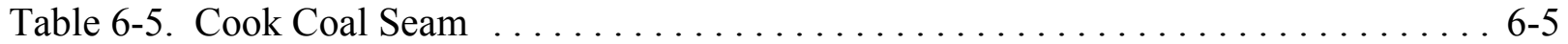

Table 6-6. Pawnee Coal Seam ............................... 6-5

Table 6-7. In-Place and Technically Recoverable CBM, Partitions \#1 and \#2 ....... 6-6

Table 6-8. Anderson Coal Seam .................................. 6-7

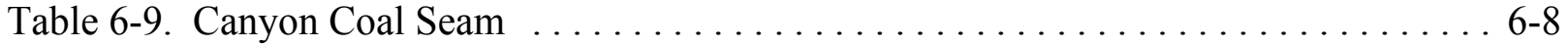

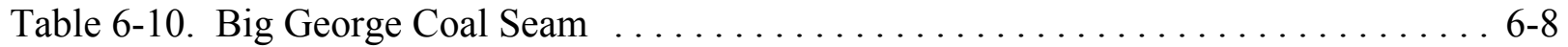

Table 6-11. Cook Coal Seam ............................... 6-9

Table 6-12. In-Place and Technically Recoverable CBM, Partitions \#3 and \#12 . . . . . . 6-9

Table 6-13. Anderson Coal Seam ............................... 6-11

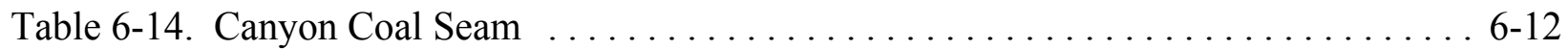

Table 6-15. Wyodak Coal Seam ............................... 6-13

Table 6-16. Cook Coal Seam ................................. 6-13

Table 6-17. Wall Coal Seam .................................. 6-14

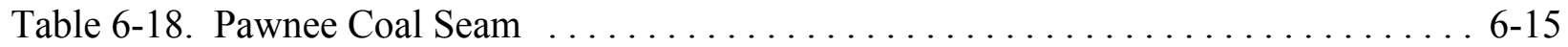

Table 6-19. Cache Coal Seam ............................... 6-16

Table 6-20. In-Place and Technically Recoverable CBM, Partition \#4 . . . . . . . . 6-16

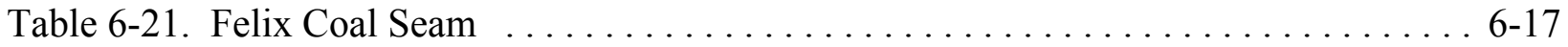

Table 6-22. Roland Coal Seam ................................ 6-18

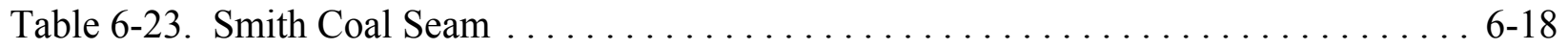

Table 6-24. Swartz Coal Seam ............................... 6-19

Table 6-25. Anderson Coal Seam .............................. 6-20

Table 6-26. Canyon Coal Seam $\ldots \ldots \ldots \ldots \ldots \ldots \ldots \ldots \ldots \ldots \ldots \ldots \ldots . \ldots \ldots . \ldots \ldots$ 6-20

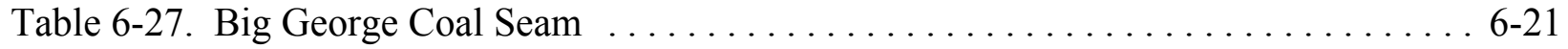

Table 6-28. Wyodak Coal Seam ............................. 6-22

Table 6-29. Cook Coal Seam ................................... 6-23

Table 6-30. Wall Coal Seam ................................ 6-23

Table 6-31. Pawnee Coal Seam ................................ 6-24

Table 6-32. Cache Coal Seam ............................... 6-25

Table 6-33. In-Place and Technically Recoverable CBM, Partition $\# 5 \ldots \ldots \ldots \ldots \ldots$ 6-25

Table 6-34. Cameron Coal Seam ................................ 6-26

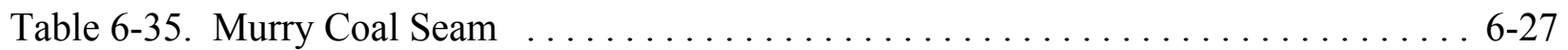

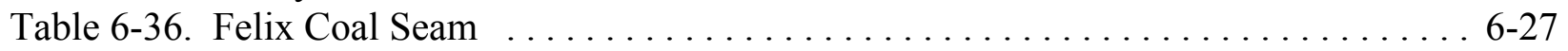

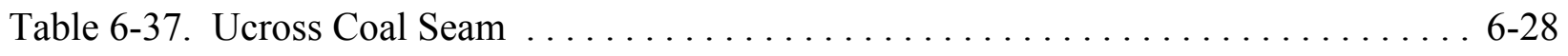




\section{TABLE OF CONTENTS}

(Continued)

Table 6-38. Roland Coal Seam ............................. 6-28

Table 6-39. Anderson Coal Seam ............................. 6-29

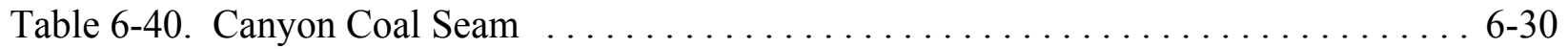

Table 6-41. Big George Coal Seam $\ldots \ldots \ldots \ldots \ldots \ldots \ldots \ldots \ldots \ldots \ldots \ldots \ldots . \ldots \ldots$

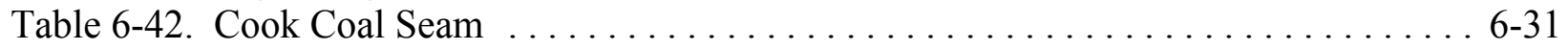

Table 6-43. Wall Coal Seam ................................ 6-31

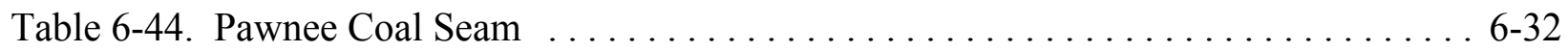

Table 6-45. In-Place and Technically Recoverable CBM, Partition $\# 6 \ldots \ldots \ldots \ldots \ldots .66-32$

Table 6-46. Wasatch Coal Seam ............................... 6-34

Table 6-47. Roland Coal Seam .............................. 6-34

Table 6-48. Smith Coal Seam .................................. 6-35

Table 6-49. Anderson Coal Seam .............................. 6-35

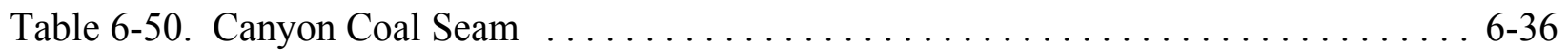

Table 6-51. Cook Coal Seam ................................ 6-37

Table 6-52. Wall Coal Seam ............................... 6-37

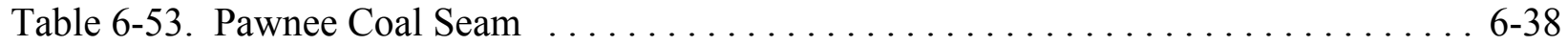

Table 6-54. Cache Coal Seam .............................. 6-38

Table 6-55. In-Place and Technically Recoverable CBM, Partition \#7 . . . . . . . . . 6-39

Table 6-56. Smith Coal Seam ................................ 6-40

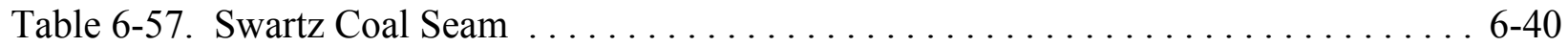

Table 6-58. Anderson Coal Seam ............................... 6-41

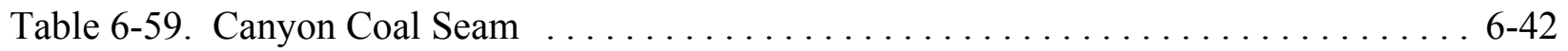

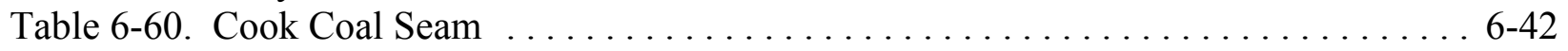

Table 6-61. Wall Coal Seam ................................. 6-43

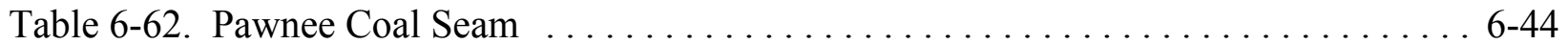

Table 6-63. Cache Coal Seam ................................ 6-44

Table 6-64. Oedekoven ................................. 6-45

Table 6-65. In-Place and Technically Recoverable CBM, Partition \#8 . . . . . . . . . 6-45

Table 6-66. Dietz Coal Seam ..................................... 6-47

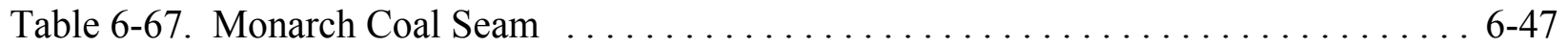

Table 6-68. Carney Coal Seam ............................. 6-48

Table 6-69. Pawnee Coal Seam ................................. 6-49

Table 6-70. In-Place and Technically Recoverable CBM, Partitions \#9 and \#10 . . . . . 6 6-49

Table 6-71. Dietz \#1 Coal Seam .................................. 6-50

Table 6-72. Dietz \#2 Coal Seam ............................... 6-51

Table 6-73. Dietz \#3 Coal Seam ............................... 6-51

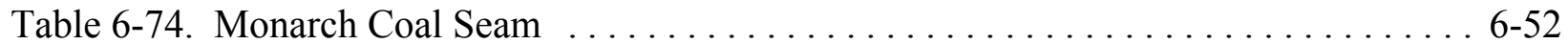

Table 6-75. Carney Coal Seam .............................. 6-53

Table 6-76. In-Place and Technically Recoverable CBM, Partition \#11 . . . . . . . . 6-53 


\section{TABLE OF CONTENTS}

(Continued)

Table A-1. Comparison PRB Wyodak Coal and Overseas Low Rank Coal . . . . . . . . A-2

Table A-2. Comparison of Gas Production Rates for Wyodak Type Well . . . . . . . . . A-9

Table A-3. Wyodak Coal Seam Properties . . . . . . . . . . . . . . . . . . . . A-10

Table A-4. Comparison of Gas Production Rates for Big George Type Well . . . . . . . . A-11

Table A-5. Big George Coal Seam Properties . . . . . . . . . . . . . . . . A A-12

Table A-6. Reservoir Parameters for Powder River Basin (Fort Union Coals) . . . . . . . A-13

Table A-7. Comparison of 1995 USGS and 2002 ARI Values for Gas Content

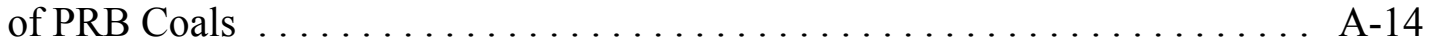




\section{EXECUTIVE SUMMARY}

The Powder River Basin coals contain a considerably larger volume of gas in place than established by previous studies. The Powder River Coalbed Methane Basin Study identifies $61 \mathrm{Tcf}$ of natural gas in-place. This in-place resource value is significantly larger than previously reported and confirms that the Powder River Basin (PRB) coalbed methane (CBM) play has the potential for providing significant additions to future domestic natural gas supplies ${ }^{1}$. Major reasons for the increased PRB coalbed methane resource in-place of $61 \mathrm{Tcf}$ in this Basin Study are the following:

- The study included extensive information on the deeper Fort Union coals prevalent in the basin, it compiled new data on the Wastach coals on the western edge of the basin, and it included the coals in the Montana portion of the PRB.

- The study identified the presence of free gas in certain coal formations and established higher gas content values for PRB coals, both increasing the gas in- place over previous estimates.

A significant portion of the coalbed methane resource in the Powder River Basin is technically recoverable. The estimate of $39 \mathrm{Tcf}$ of technically recoverable resources is based on reservoir modeling and the construction of 142 "type wells" representative of the distribution in well performance (gas and water production) for 12 distinct coal seams in 12 basin partitions. All results include CBM development to date in the basin. The Basin Study's estimate of technically recoverable coalbed methane resources for the Powder River updates earlier estimates by the Potential Gas Committee (2000) of 24 Tcf and by the U.S. Geological Survey (2002) of 14 Tcf.

The costs and economic feasibility of further developing coalbed methane in the Powder River Basin will be significantly impacted by produced water management practices and requirements. The study finds that alternative produced water management options will have a profound influence on the economic viability of producing coalbed methane from the PRB. The costs of the alternative water management options in the PRB - assessed using a 15\%, before corporate income tax, internal rate of return (IRR) and a long-term natural gas price (at the Henry Hub) of $\$ 3$ per Mcf as the economic threshold criteria - are significant and can make an otherwise profitable CBM project uneconomic.

The results of the economic analyses are presented on Table S-1 and are further discussed below.

${ }^{1}$ Increased potential, however, should not be confused with additional impact. Higher per well gas recoveries will allow development of the resource using far fewer wells and as a consequence, with much less disturbance. In fact, this analysis forecasts that several thousand fewer wells will be needed to develop the CBM resources in the Powder River Basin, compared to widely-accepted well count estimates. Moreover, prudent resource development is expected to lead to less water production-billions of barrels less-as compared to the draft EIS estimate. 


\section{Table S-1. Volumes of Economically Recoverable CBM w/Alternative Water Disposal Options (Tef)}

\begin{tabular}{|l||c|c|c|c|}
\hline Economic Conditions & $\begin{array}{c}\text { Surface } \\
\text { Discharge }\end{array}$ & Impoundment & $\begin{array}{c}\text { Shallow } \\
\text { Reinjection }\end{array}$ & $\begin{array}{c}\text { Active } \\
\text { Treatment }\end{array}$ \\
\hline Case 1 (Today) & 1.5 & -- & -- & -- \\
\hline Case 2 (Transition) $^{* *}$ & 22.4 & 20.0 & 18.8 & $7.1-10.2$ \\
\hline Case 3 (Long Term)*** & 29.1 & 27.8 & 27.1 & $17.8-21.6$ \\
\hline
\end{tabular}

${ }^{*}$ Basin differential remains at $\$ 1.80$ per Mcf.

${ }^{* *}$ Basin differential narrows from $\$ 1.80$ per Mcf in year 1 to $\$ 0.80$ per Mcf in year 3 and beyond.

${ }^{* * *}$ Basin differential is $\$ 0.80$ per Mcf.

- Under today's volatile natural gas prices and unfavorable Wyoming basin differentials, only using surface disposal of produced water is economic. And, this low cost water management option is economic only in selected, highly productive portions of the PRB. More costly water disposal options would preclude further economic development of coalbed methane in the Powder River Basin. A significant portion of the $1.5 \mathrm{Tcf}$ of economic CBM potential, shown in Table S-1, is already under development, leaving little opportunity for further economically justified expansion (at today's conditions and standard economic criteria) in the Powder River Basin.

- $\quad$ Assuming a transition toward more normal Wyoming basin price differentials, a significant portion of the basin becomes economic to further develop, with water management practices of surface discharge, impoundment or shallow re-injection ${ }^{2}$. Requiring active treatment of the water (with current reverse osmosis technology) greatly reduces the economically viable potential for CBM in the PRB. Specifically, instead of 19 to $22 \mathrm{Tcf}$ of economically recoverable coalbed methane (using one of the first three water management options, shown in Table S-1), only 7 to 10 Tcf of coalbed methane remains economic to develop with a requirement for active water treatment. This represents a loss of $12 \mathrm{Tcf}$ of otherwise economically recoverable natural gas resource from the Powder River Basin.

- Taking a long-term outlook on prices and assuming that the Wyoming basin differential returns to historically more normal values, the economically developable CBM resources of the PRB range from 27 to $29 \mathrm{Tcf}$ (for the three lower cost water management options). Requiring active treatment of water (with current reverse osmosis technology) reduces the economically viable PRB CBM potential to a range of 18 to $22 \mathrm{Tcf}$ for a loss of 7 to 9 Tcf of otherwise economically recoverable natural gas resource.

${ }^{2}$ Shallow re-injection is considered in a generic sense and evaluated from a theoretical standpoint. Much uncertainty exists surrounding the real availability of shallow zones with the required geology and fluid flow properties necessary for long-term successful projects. 
The loss of CBM resources, royalties and tax receipts from more stringent CBM produced water management practices would be substantial. Table S-2 provides a summary of the potential losses that would occur from requirements to use progressively more stringent water disposal alternatives. The PRB Study recognizes that, in practice, a combination of water disposal alternatives would be used. Once the final mix of options is established, the information in this study can be used to estimate these impacts.

Table S-2. Summary of Impacts from Using Alternative Water Disposal Methods for CBM Produced Water in the PRB

\begin{tabular}{|l|c|c|c|}
\hline \multirow{2}{*}{ Water Disposal Method } & $\begin{array}{c}\text { Loss of CBM } \\
\text { Resource }\end{array}$ & $\begin{array}{c}\text { Loss of CBM } \\
\text { Royalty }\end{array}$ & $\begin{array}{c}\text { Loss of } \\
\text { Production/ } \\
\text { Ad Valorem Taxes }\end{array}$ \\
\cline { 2 - 4 } & $($ Tcf) & (\$ million) & (\$ million) \\
\hline Surface Discharge & -- & -- & -- \\
\hline Infiltration Impoundment & $(2.4)$ & $(\$ 506)$ & $(\$ 362)$ \\
\hline Shallow Re-injection & $(3.6)$ & $(\$ 756)$ & $(\$ 540)$ \\
\hline Reverse Osmosis/w: & \multicolumn{3}{|c|}{} \\
\hline - Trucking of Residual & $(15.3)$ & $(\$ 3,184)$ & $(\$ 2,272)$ \\
\hline - Deep Disposal of Residual & $(12.2)$ & $(\$ 2,547)$ & $(\$ 1,810)$ \\
\hline
\end{tabular}

Improvements in coalbed methane production technology and water management practices can help maintain the economic viability of Powder River coalbed methane. The current volatile natural gas prices and historically high basin differentials place major hurdles on the economics of Powder River CBM. Further raising the barrier is the recognition that a considerable portion of the shallower, thick coals in the basin have already been drilled, leaving deeper and thinner coals as the target. Finally, the costs of more stringent water management practices will further lower the economic viability of this large natural gas resource. 


\subsection{STUDY PURPOSE, APPROACH AND FINDINGS}

\subsection{Purpose of Study}

The overall purpose of the Powder River Basin Study is to assist DOE/FE, NETL and NPTO better understand the energy impacts of the alternative water disposal options being considered for Powder River Basin coalbed methane. The specific objectives of the study are:

1. Develop a stronger data and analytical base for the geology, resources and CBM potential of the Powder River Basin.

2. Divide the basin into a series of geologically similar partitions to facilitate the analysis of well performance and costs.

3. Project CBM and water production rates for a series of typical wells and the distribution of well performance in each partition.

4. Assemble information on the costs of CBM development and produced water management, including cash flows and economics.

\subsection{Background}

The Powder River Basin of Wyoming and Montana is the site of the fastest growing domestic natural gas play - the development of coalbed methane (CBM) from the Wyodak and Big George fairways. As of the end of 2001:

- $\quad$ Nearly 12,000 CBM wells have been drilled with 8,177 wells producing.

- $\quad$ Coalbed methane production is at 823 million cubic feet a day (MMcfd) up from 111 MMcfd just three years earlier, as shown in Figure 1-1.

Along with the growth in CBM production has been the growth in produced water, as part of dewatering and depressuring the coal formations thus enabling the coals to release their adsorbed methane. As of the end of 2001, water production was at 1,444,000 barrels per day, up from 229,000 barrels per day at the end of 1998, as shown in Figure 1-2.

Progressive CBM development and dewatering, while increasing total water production, is leading to lower water to gas ratios and lower average production of water per well:

- The water to gas production ratio (at the end of 2001) is 1.75 barrels per Mcf, down from 2.88 barrels per Mcf two years ago, as shown in Figure 1-3.

- Water production per CBM well (at the end of 2001) is 177 barrels per day, down from 396 barrels per day two years ago, as shown in Figure 1-4. 


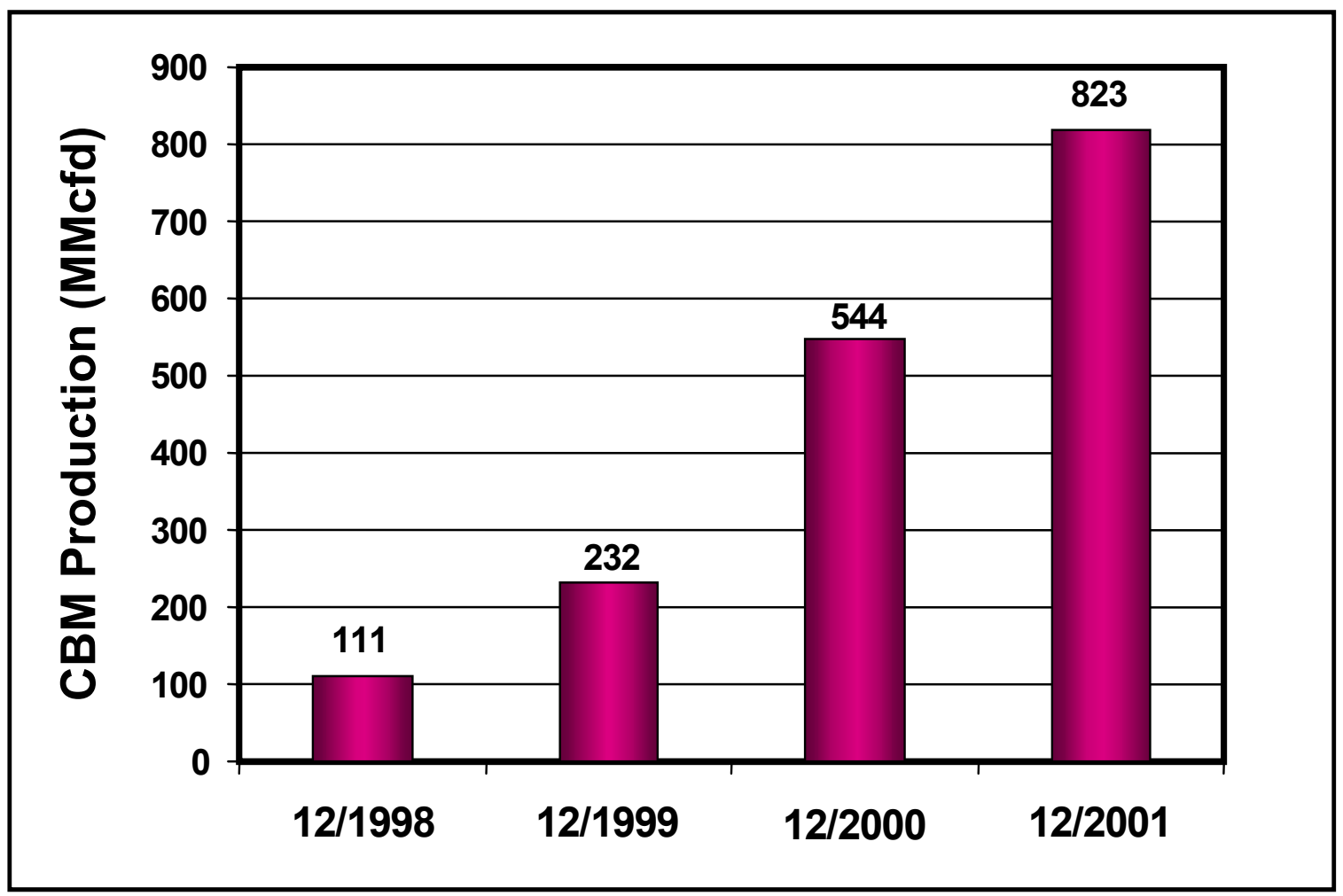

Figure 1-1. Powder River Basin, Growth of Coalbed Methane Production

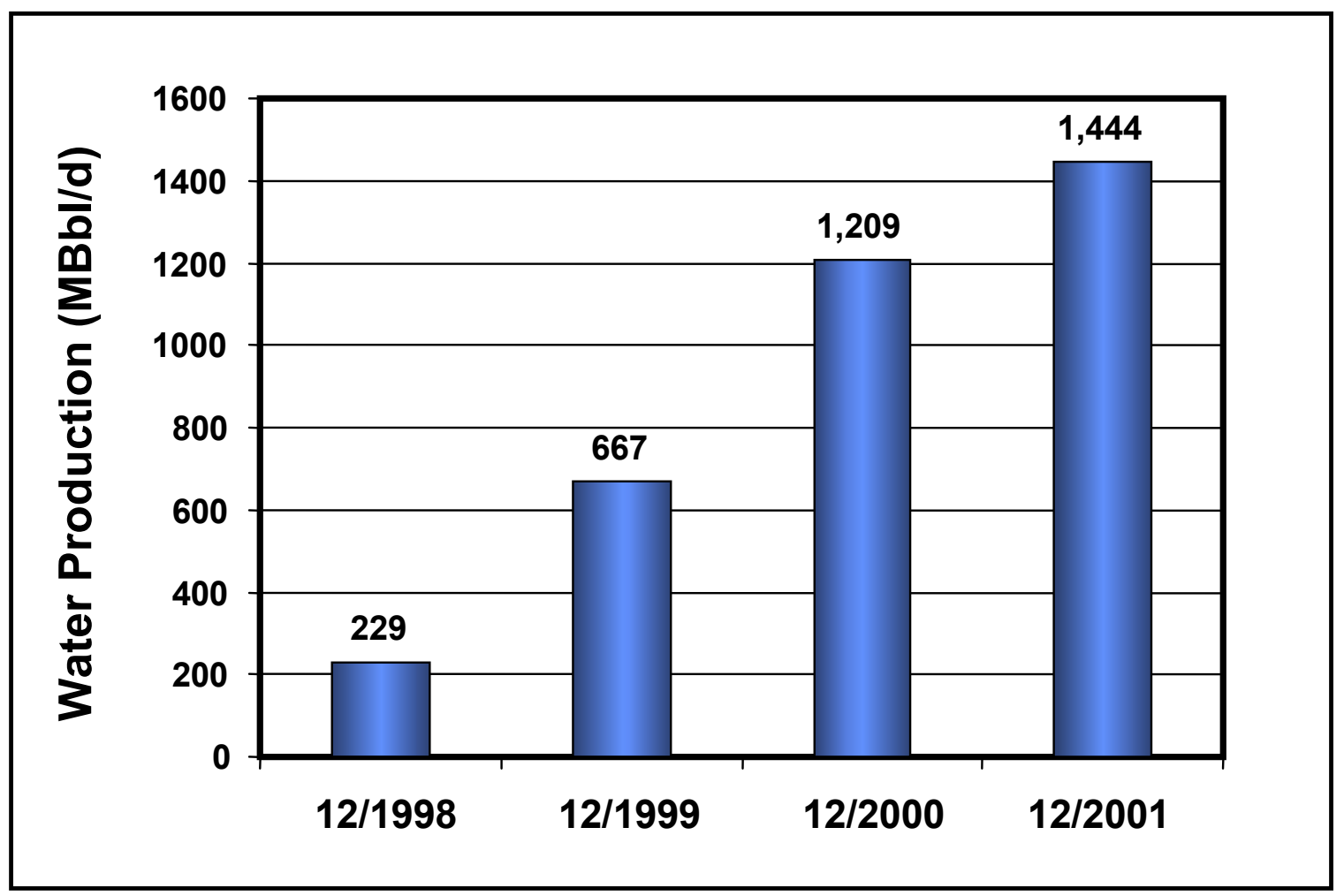

Figure 1-2. Powder River Basin, Growth in CBM Water Production 


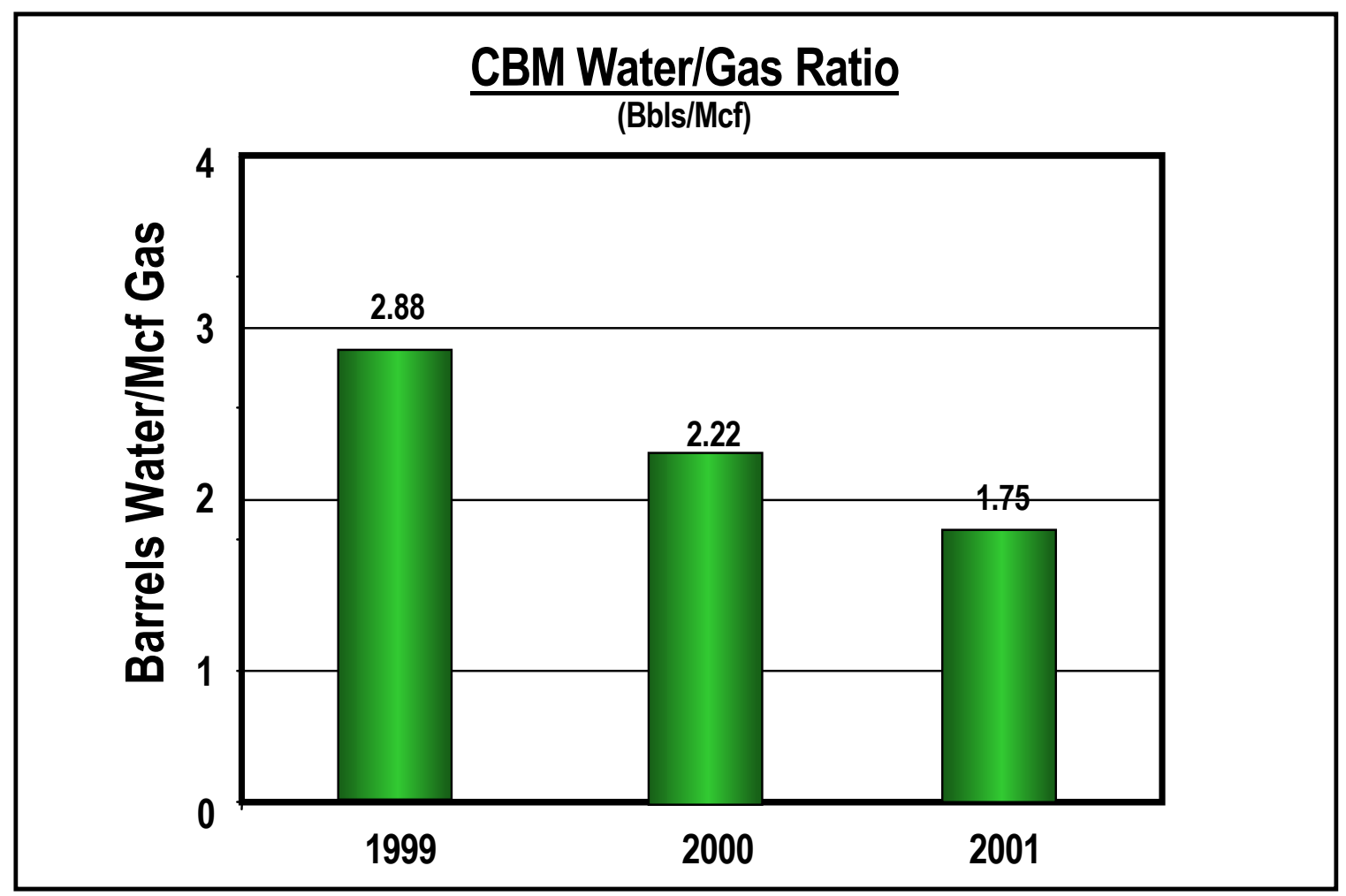

Figure 1-3. CBM Water/Gas Production Ratio

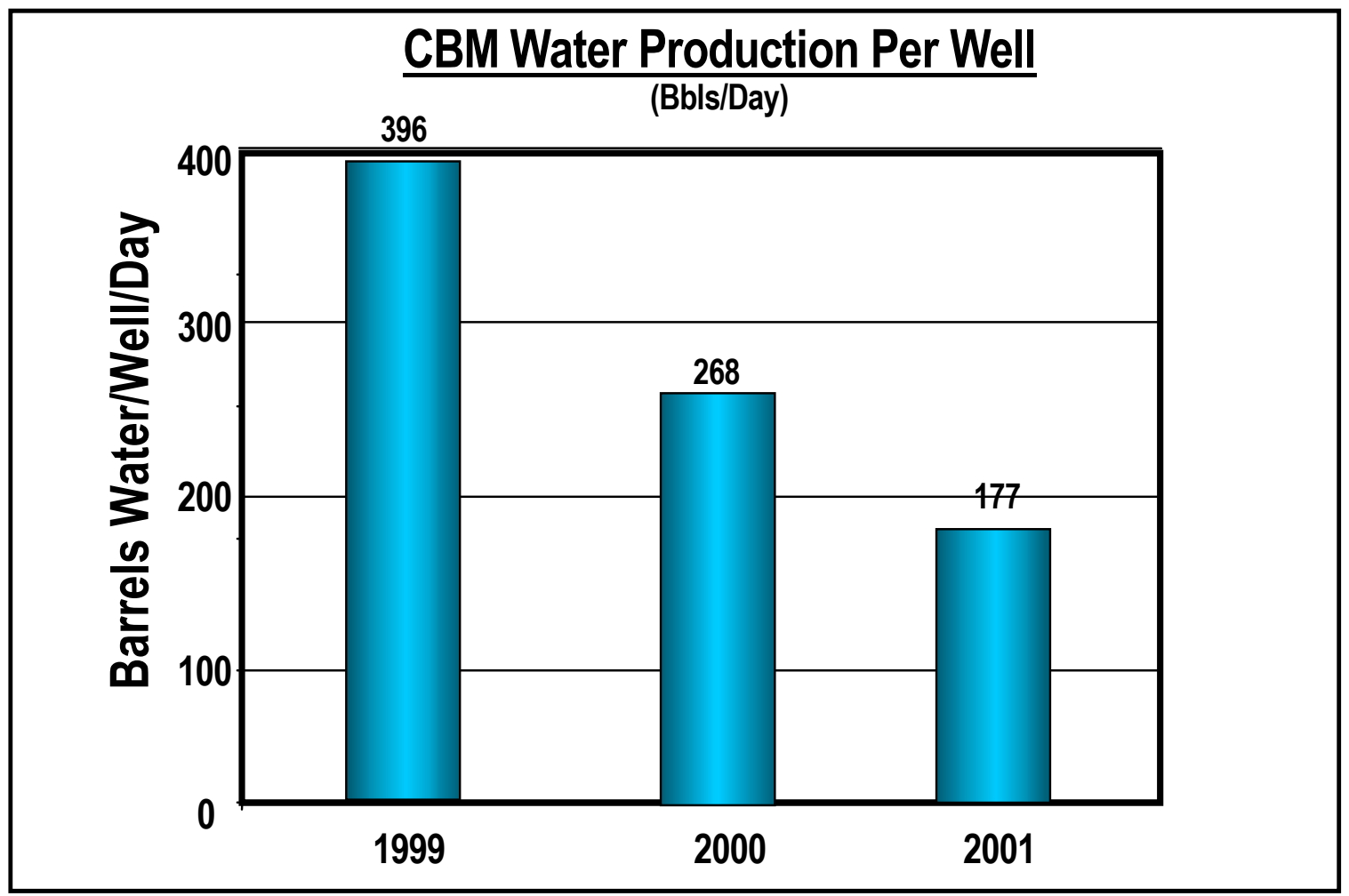

Figure 1-4. CBM Water Production Per Well

For the most part, produced CBM waters are either surface discharged or placed into impoundments providing beneficial use for agriculture, stock watering and grasslands. Should beneficial 
use of produced CBM water be constrained, other (more costly) options would need to be considered, impacting the economics and natural gas resource development in the basin. These options include: (a) shallow re-injection to conserve the water for future use; (b) pre-treatment of water with chemicals and reverse osmosis, with deep disposal of the residual concentrate; and/or, (C) deep re-injection into non-potable water disposal aquifers.

\subsection{Partitioning the Powder River Basin}

To provide a series of geologically consistent analytic units, the Powder River Basin is divided into 12 partitions, based on coal depth, development status, and geographic considerations. The 12 basin partitions are shown in Figure 1-5, and consist of the following:

1. Southern Extension

2. South Eastern Area

3. South Central Area

4. East Central Area

5. Main Central Area

6. West Central Area

7. North Western Area

8. North Eastern Area

9. Eastern Montana Area

10. Western Montana Area

11. NW Basin Edge, Wyoming

12. SW Basin Edge, Wyoming

Partition \#4, in the east-central portion of the Power River, has seen the most extensive coalbed methane development, as well as surface mining of coal. Figures 1-6 through 1-8 show the extent of coalbed methane development (as of the end of 2001) for the Anderson, Canyon and Wyodak coal seams in Partition \#4, and in surrounding townships along the eastern portion of the PRB.

This study provides the gas in-place, recoverable resources and economics of each of the major coal seams in each of these 12 basin partitions. 


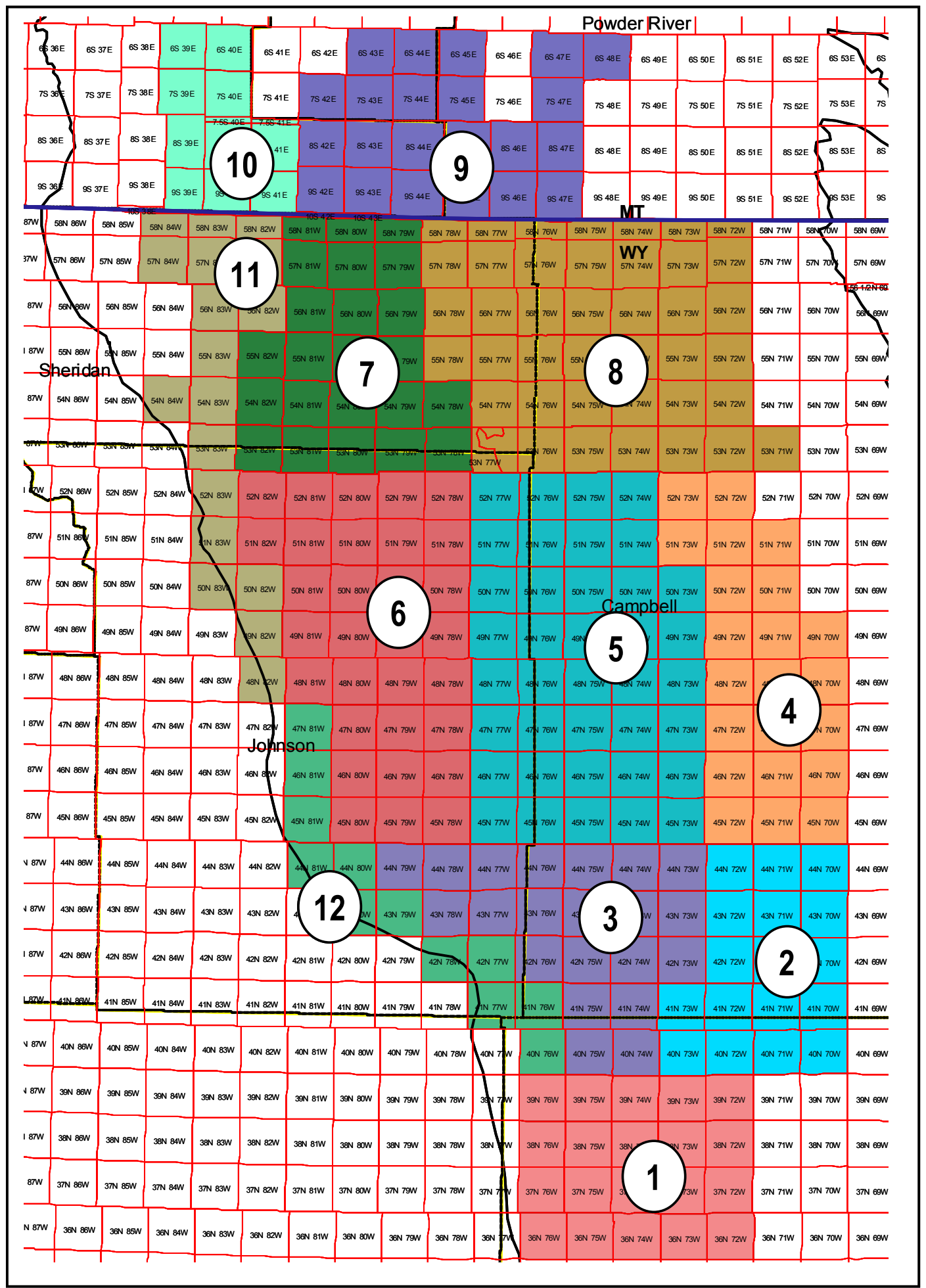

Figure 1-5. Powder River Basin CBM Partitions. 


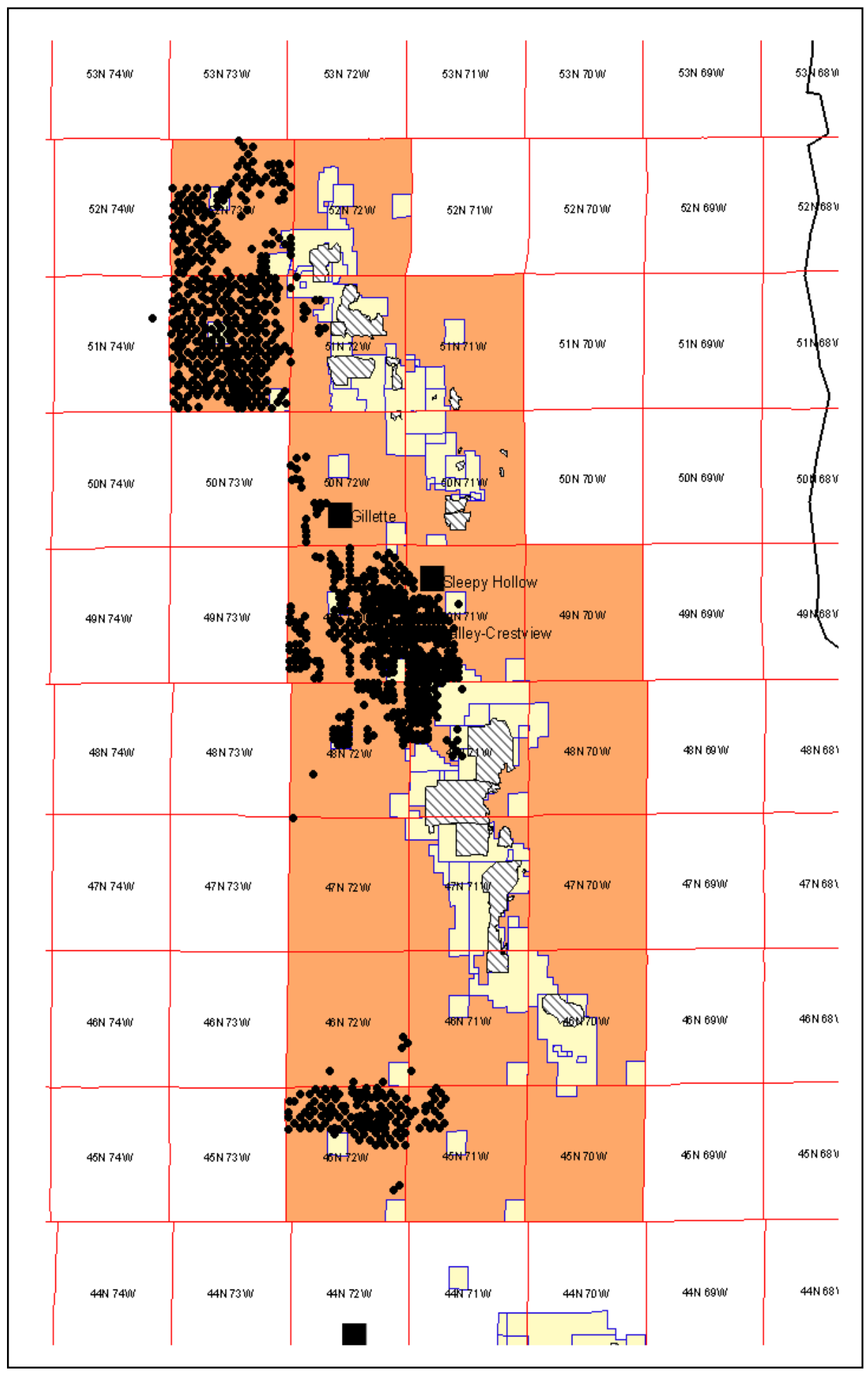

Figure 1-6. Extent of CBM Drilling Map, Partition \#4, Anderson Coal Seam Wells 


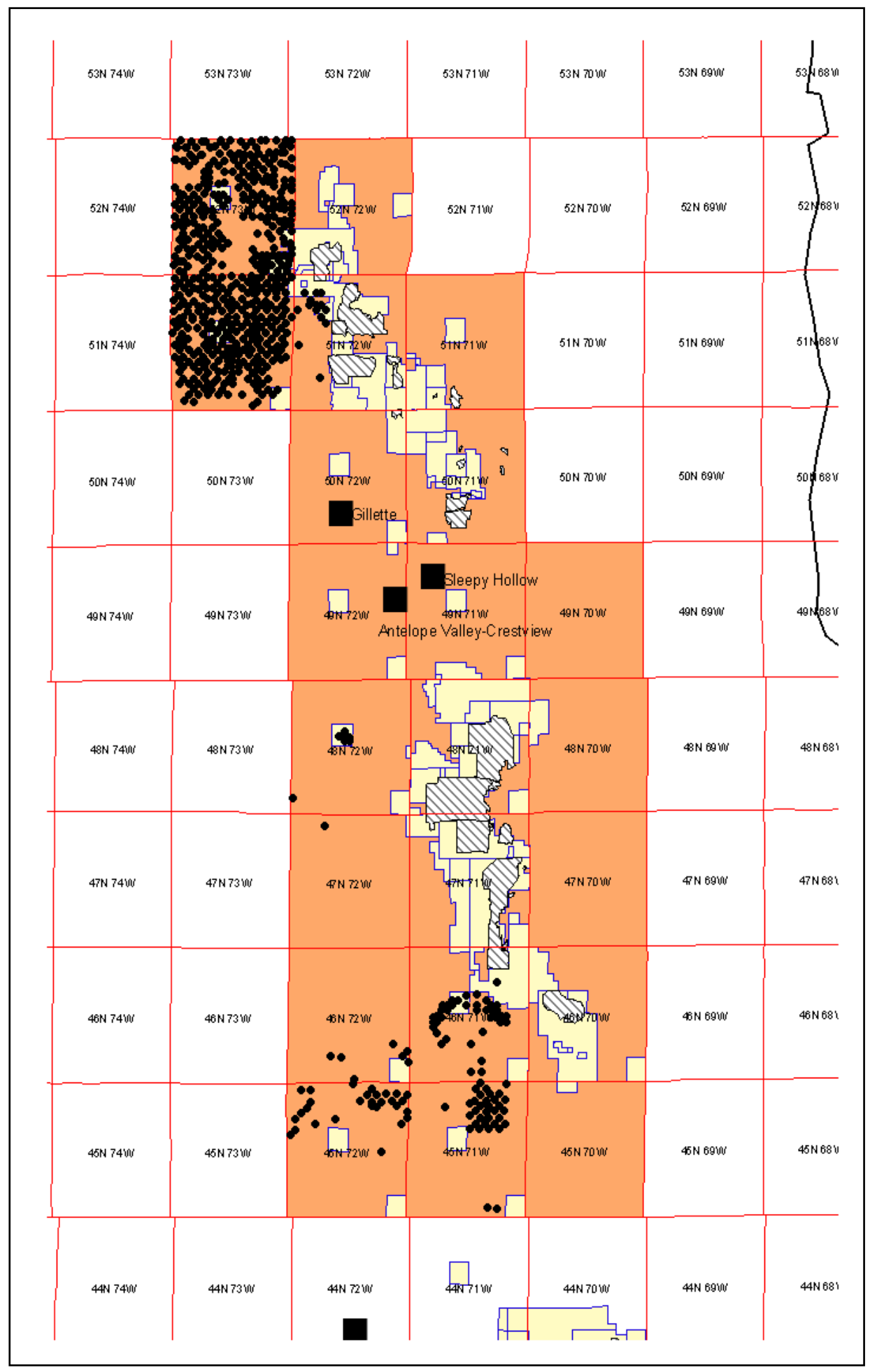

Figure 1-7. Extent of CBM Drilling Map, Partition \#4, Canyon Coal Seam Wells 


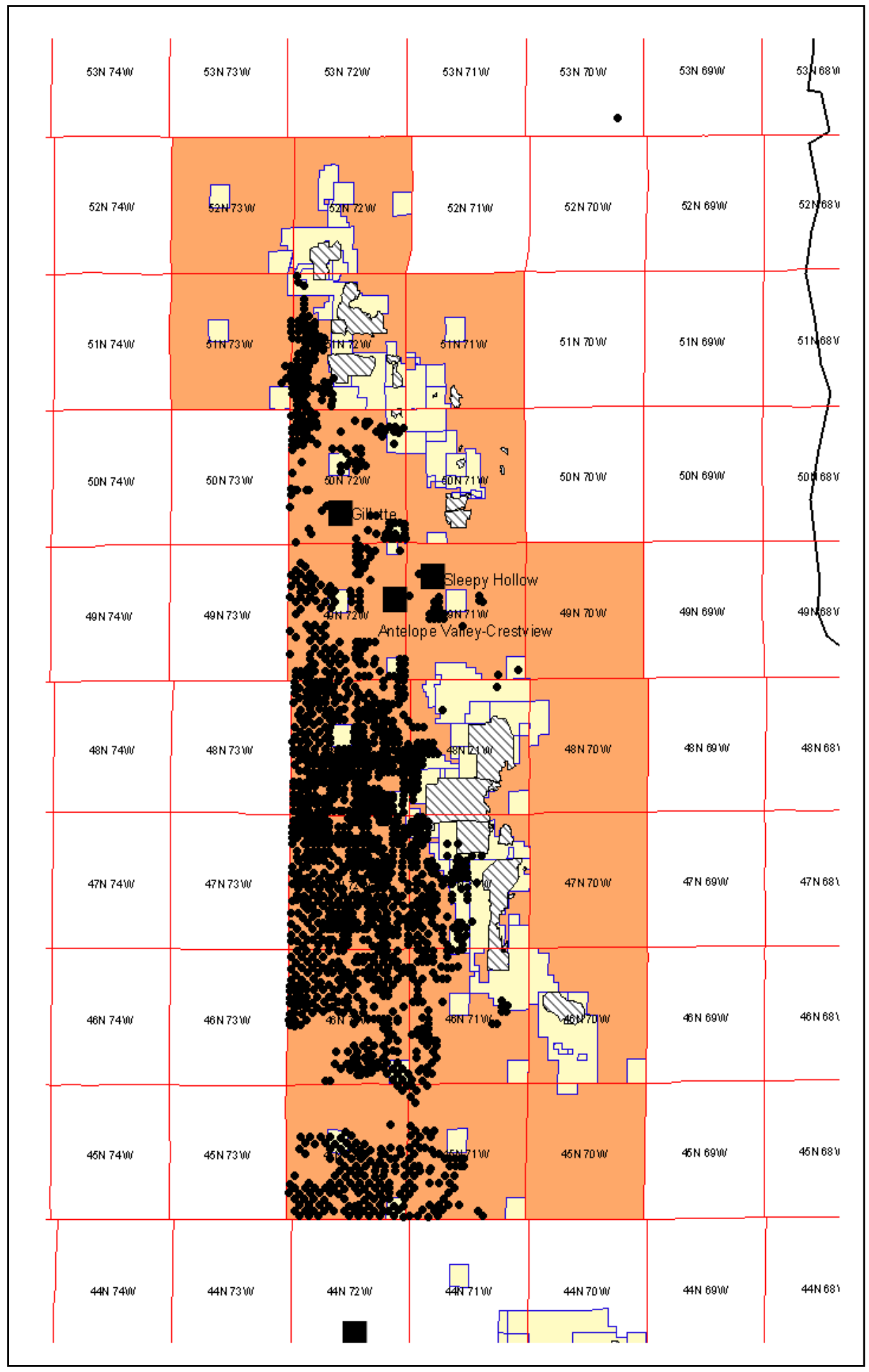

Figure 1-8. Extent of CBM Drilling Map, Partition \#4, Wyodak Coal Seam Wells 


\subsection{Study Approach}

\subsubsection{Coal Resource Data Base}

The Basin Study compiled available geologic data on the areal extent and thickness of the major Fort Union Formation coals in the PRB that met the following criteria:

- $\quad$ Below 300 feet of depth

- $\quad$ Thicker than 20 feet

- $\quad$ Sufficient data exist

For Montana, the depth and coal thickness criteria were relaxed (250 feet of depth and 15 feet of coal thickness) to more fully capture the coal and CBM resources in this portion of the basin. Even so, the CBM resources of Montana are only partly defined, as insufficient data existed for the deeper Knoblock coal zone in this portion of the basin.

A variety of data sources were used by the Basin Study, including data from the USGS, Wyoming and Montana State offices, private data and supplemental log analysis, as set forth in Tables 1-1 and 1-2.

The available data were assembled on a township by township basis for each of the major coal seams in the basin. Special attention was given to assembling new data on the deep coals in the central portion of the PRB and on the Wasatch coals along the western edge of the PRB.

\subsubsection{Projecting Gas and Water Production}

The coalbed methane and water production estimates in the Basin Study were developed as follows:

The geologic model of the PRB (discussed in Chapter 2) provided the key reservoir properties of coal seam depth, thickness, gas content, and reservoir pressure.

A gas and water production data base (discussed in Chapter 3) of over 8,000 CBM wells in the PRB was organized by coal seam and by partition and then normalized by time (using "time zero" plots) to provide a foundation of actual CBM well performance.

History matching of gas and water production (discussed in Chapter 3) from 1,428 PRB CBM wells, organized into 14 distinct coal-seam and basin-partition sets, was used to establish:

- $\quad$ Permeability (matrix, fracture)

- Coal porosity (matrix, fracture)

- $\quad$ Gas and water saturation

- $\quad$ Confirmation of reservoir pressure and gas content 


\section{Table 1-1. Reports and Data for Powder River CBM and Produced Water Management Study}

\begin{tabular}{|c|c|c|}
\hline Group & File & Full Description \\
\hline USGS & BULL 1078 & $\begin{array}{l}\text { Mapel, W.J., 1959, Geology and coal resources of the Buffalo-Lake de Smet area, Johnson } \\
\text { and Sheridan Counties, Wyoming: U.S. Geological Survey Bulletin 1078, } 148 \text { p. }\end{array}$ \\
\hline USGS & BULL 1917-F & $\begin{array}{l}\text { Nichols, D.J., and Brown, J.L., 1992, Palynostratigraphy of the Tullock Member (lower } \\
\text { Paleocene) of the Fort Union Formation in the Powder River Basin, Montana and Wyoming: } \\
\text { U.S. Geological Survey Bulletin 1917-F, } 35 \text { p., } 10 \text { pls. }\end{array}$ \\
\hline USGS & Cl C-119-A. & $\begin{array}{l}\text { McLellan, M.W., and Biewick, L.H., 1988, Stratigraphic framework of the Paleocene coal beds } \\
\text { in the Broadus 30' x 60' quadrangle, Powder River Basin, Montana-Wyoming: U.S. } \\
\text { Geological Survey Coal Investigations Map C-119-A. }\end{array}$ \\
\hline USGS & CI MAP C-113 & $\begin{array}{l}\text { Culbertson, W.C., 1987, Diagrams showing proposed correlation and nomenclature of } \\
\text { Eocene and Paleocene coal beds underlying the Birney 30' x 60'quadrangle, Big Horn, } \\
\text { Rosebud, and Powder River Counties: U.S. Geological Survey Coal Investigations Map } \\
\text { C-113. }\end{array}$ \\
\hline USGS & CI MAP C-2 & $\begin{array}{l}\text { Combo, J.X., Holmes, C.N., and Christner, H.R., 1978, Map showing the coal resources of } \\
\text { Montana: U.S. Geological Survey Coal Investigations Map C-2. }\end{array}$ \\
\hline WGS & CIR 14 & $\begin{array}{l}\text { Glass, G.B., 1998, Coal resources of the Powder River Basin, in, Guidebook to Coal Geology } \\
\text { of the Powder River Basin: Wyoming Geological Survey Information Circular no. 14, p. 97- } \\
\text { 131. }\end{array}$ \\
\hline USGS & CIR 53 & $\begin{array}{l}\text { Combo, J.X., Brown, D.M., Pulver, H.F., and Taylor, D.A., 1949, Coal resources of Montana: } \\
\text { U.S. Geological Survey Circular 53, } 28 \text { p. }\end{array}$ \\
\hline USGS & CIR 81 & $\begin{array}{l}\text { Berryhill, H.L., Jr., Brown, D.M., Brown, A., and Taylor D.A., 1950, Coal resources of } \\
\text { Wyoming: U.S. Geological Survey Circular 81, } 78 \text { p. }\end{array}$ \\
\hline WGS & FIELD GUIDE & $\begin{array}{l}\text { Culbertson, W.C., and Mapel, W.J., 1976, Coal in the Wasatch Formation, northwest part of } \\
\text { the Powder River Basin near Sheridan, Sheridan County, Wyoming: Wyoming Geological } \\
\text { Association Guidebook 28th Annual Field Conference, p. 193-201. }\end{array}$ \\
\hline WGS & GUIDEBOOK & $\begin{array}{l}\text { Mapel, W.J., 1958, Coal in the Powder River Basin: Wyoming Geological Association } \\
\text { Guidebook, 13th Annual Field Conference, p. 218-224. }\end{array}$ \\
\hline USGS & I-1128 & $\begin{array}{l}\text { Law, B.E., Barnum, B.E., and Wollenzien, T.P., 1979, Coal bed correlations in the Tongue } \\
\text { River Member of the Fort Union Formation, Monarch, Wyoming, and Decker, Montana, areas: } \\
\text { U.S. Geological Survey Miscellaneous Investigations Series Map I-1128. }\end{array}$ \\
\hline USGS & I-1959A & $\begin{array}{l}\text { McLellan, M.W., Biewick, L.H., Molnia, C.L., and Pierce, F.W., 1990, Coal stratigraphy of } \\
\text { northern and central Powder River Basin, Montana and Wyoming: U.S. Geological Survey } \\
\text { Miscellaneous Investigations Series Map I-1959-A. }\end{array}$ \\
\hline USGS & I-1959-B & $\begin{array}{l}\text { Pierce, F.W., Johnson, E.A., Molnia, C.L., and Sigleo, W.R., 1990, Coal stratigraphy of the } \\
\text { southeastern Powder River Basin, Wyoming: U.S. Geological Survey Miscellaneous } \\
\text { Investigations Map I-1959-B. }\end{array}$ \\
\hline USGS & I-1959-C (MAP) & $\begin{array}{l}\text { Hardie, J.K., 1991, Coal stratigraphy of the southwestern Powder River Basin,Wyoming: } \\
\text { U.S. Geological Survey Miscellaneous Investigations Series Map I-1959-C. }\end{array}$ \\
\hline USGS & I-1959-D & $\begin{array}{l}\text { Molnia, Carol L., and Pierce, Frances Wahl, 1992, Cross sections showing coal stratigraphy } \\
\text { of the central Powder River Basin, Wyoming and Montana: U.S. Geological Survey Miscel- } \\
\text { laneous Investigations Series Map I-1959-D, scale 1:500,000. }\end{array}$ \\
\hline USGS & I-2011 & $\begin{array}{l}\text { Pierce, F.W., and Johnson, E.A., 1991, Stratigraphic cross section showing upper Paleocene } \\
\text { coal-bearing rocks of the Tongue River Member of the Fort Union Formation in the Piney } \\
\text { Canyon NE and Piney Canyon NW quadrangles, Campbell and Weston Counties, south- } \\
\text { eastern Powder River Basin, Wyoming: U.S. Geological Survey Miscellaneous Investigations } \\
\text { Series Map I-2011. }\end{array}$ \\
\hline USGS & I-2013 & $\begin{array}{l}\text { Johnson, E.A., and Pierce, F.W., 1991, Stratigraphic cross section showing upper Paleocene } \\
\text { coal-bearing rocks of the Tongue River Member of the Fort Union Formation in the Coal Bank } \\
\text { Draw and Dugout Creek North quadrangles, Campbell and Weston Counties, southeastern } \\
\text { Powder River Basin, Wyoming: U.S. Geological Survey Miscellaneous Investigations Series } \\
\text { Map I-2013. }\end{array}$ \\
\hline
\end{tabular}




\title{
Table 1-1. Reports and Data for Powder River CBM and Produced Water Management Study
}

\author{
(Continued)
}

\begin{tabular}{|c|c|c|}
\hline Group & File & Full Description \\
\hline USGS & ISBN 1-890977-15-2 & $\begin{array}{l}\text { Roberts, L.N.R., Mercier, T.J., Biewick, L.R.H., and Blake, Dorsey, 1998, A procedure for } \\
\text { producing maps and resource tables of coals assessed during the U.S. Geological Survey's } \\
\text { National Coal Assessment: Fifteenth Annual International Pittsburgh Coal Conference } \\
\text { Proceedings, CD-ROM (ISBN 1-890977-15-2), } 4 \text { p. }\end{array}$ \\
\hline USGS & MF-1779 \& MF-1929 & $\begin{array}{l}\text { Weaver, J.N., and Flores, R.M., 1985, Stratigraphic framework of the upper Fort Union } \\
\text { Formation at the TA Hills, Western Powder River Basin, Wyoming: U.S. Geological Survey } \\
\text { Miscellaneous Field Studies Map, MF1779 \& MF-1929. }\end{array}$ \\
\hline USGS & MF-1127 \& MF-1126 & $\begin{array}{l}\text { Flores, R.M., 1979, Restored stratigraphic cross sections and coal correlations in the Tongue } \\
\text { River member of the Fort Union Formation, Powder River area, Montana: U.S. Geological } \\
\text { Survey, Miscellaneous Field Studies Map MF-1127 \& MF-1126. }\end{array}$ \\
\hline USGS & MF-1796 & MF-1796 \\
\hline USGS & OF $76-450$ & OF 76-450 \\
\hline USGS & OF $77-283$ & OF 77-283 \\
\hline USGS & OF 77-721 & OF 77-721 \\
\hline USGS & OF $79-1201$ & $\begin{array}{l}\text { Culbertson, W.C., Kent, B.H., and Mapel, W.J., 1979, Preliminary diagrams showing correla- } \\
\text { tion of coal beds in the Fort Union and Wasatch Formations across the northern Powder River } \\
\text { Basin, northeastern Wyoming and southeastern Montana: U.S. Geological Survey Open-File } \\
\text { Report 79-1201. }\end{array}$ \\
\hline USGS & OF 82-026 & OF 82-026 \\
\hline USGS & OF 85-621 & $\begin{array}{l}\text { Trent, V.A., 1985, Summary of results of the Coal Resource Occurance and Coal Develop- } \\
\text { ment Potential Mapping Program in Part of the Powder River basin, MT \& WY: U.S. Geo- } \\
\text { logical Survey Open-file Report 85-621,49 p.,1 pl., } 2 \text { fig., } 14 \text { tables, Scale 1:1,000,000. }\end{array}$ \\
\hline USGS & PP 1625-A & $\begin{array}{l}1999 \text { Resource Assessment of Selected Tertiary Coal Beds and Zones in the Northern Rocky } \\
\text { Mountains and Great Plains Region. }\end{array}$ \\
\hline WGS & OF 92-4 & $\begin{array}{l}\text { Jones, Richard, and Glass G., 1991, Demonstrated reserve base of coal in Wyoming as of } \\
\text { January 1, 1991: Wyoming Geological Survey Open-File Report 92-4. }\end{array}$ \\
\hline USGS & OF 97-469 & $\begin{array}{l}\text { Molnia, C.L., Biewick, L.R.H., Blake, Dorsey, Tewalt, S.J., Carter, M.D., and Gaskill, Charlie, } \\
\text { 1997, Coal availability in the Hilight quadrangle, Powder River Basin, Wyoming: a prototype } \\
\text { study in a western coal field: U.S. Geological Survey Open-File Report 97-469, } 21 \text { p. }\end{array}$ \\
\hline WGS & RI 35 & $\begin{array}{l}\text { Ayers, W.B., Jr., 1986, Coal resources of the Tongue River Member of the Fort Union } \\
\text { Formation (Paleocene), Powder River Basin, Wyoming and Montana: Geological Survey of } \\
\text { Wyoming Report of Investigations No. 35, } 22 \text { p. }\end{array}$ \\
\hline WRD & WRIR 85-4305 & $\begin{array}{l}\text { Daddow, P.B., 1986, Potentiametric-Surface map of the Wyodak-Anderson coal bed, Powder } \\
\text { River Structural Basin, Wyoming, 1973-84: U.S. Department of the Interior, Water Resources } \\
\text { Division, Water Resources Investigation Report 85-4305 (prepared in cooperation with the } \\
\text { Bureau of Land Management). }\end{array}$ \\
\hline BLM & & $\begin{array}{l}\text { Bureau of Land Management, 1996, Powder River Basin Coal Production-1995; N. Braz, C. } \\
\text { Gaskill and R. Nelson compilers, U.S. Department of the Interior, Bureau of Land Manage- } \\
\text { ment, Casper, Wyoming, file Dldrawingslwo-map.dwg. }\end{array}$ \\
\hline USGS & & $\begin{array}{l}\text { U.S. Geological Survey Global Land Information System-GLIS, 1997, digital spatial data } \\
\text { obtained from http://edcwww.cr.usgs.gov/glis/glis.html. }\end{array}$ \\
\hline BLM & & www.wy.blm.gov/minerals/og/re's.mgt/resevmgt.html \\
\hline
\end{tabular}


Table 1-2. Electronic Data Sources for Powder River CBM and Produced Water Management Study

\begin{tabular}{|c|l|}
\hline 1. & Field Conference - Coalbed Methane - Powder River OF01-126 \\
\hline 2. & http://greenwood.cr.usgs.gov/energy/coal/OF-97-469.html \\
\hline 3. & http://greenwood.cr.usgs.gov/pub/open-file-reports/ofr-98-0789-a/ \\
\hline 4. & http://greenwood.cr.usgs.gov/pub/open-file-reports/ofr-98-0789-b/ \\
\hline 5. & http://www.cbmcc.vcn.com/ \\
\hline 6. & http://www.prb-eis.org/ \\
\hline 7. & US Coal Quality Database \\
\hline 8. & http://www.deq.state.mt.us/coalbedmethane/ \\
\hline 9. & http://www.cbmwyo.org \\
\hline 10. & http://www.powderriverbasin.org \\
\hline 11. & http://energy.cr.usgs.gov/oilgas/cbmethane/ \\
\hline 12. & http://deq.state.wy.us/ \\
\hline 13. & http://wogcc.state.wy.us/ \\
\hline 14. & http://www.wsgsweb.uwyo.edu/ \\
\hline 15. & http://www.wy.blm.gov/Directory/fo_map/fo_map.html \\
\hline 16. & Rick Marvel @WYOGC rmarve@state.wy.us 307-234-7147 \\
\hline 17. & http://bogc.dnrc.state.mt.us/ \\
\hline
\end{tabular}

Advanced Resources' COMET3 reservoir simulator, a triple porosity and triple permeability finite difference model, specifically developed for coalbed methane production and reserve assessments, was used for history matching and establishing 14 "type wells" reflecting the geologic and reservoir diversity encountered by PRB coals (discussed in Chapter 3).

The history-matched "type wells" were extended in time (using COMET3) to provide ten year coalbed methane and water production rates and estimates of ultimate gas and water recovery (discussed in Chapter 3).

The 14 PRB "type wells" were scaled using actual depth, thickness and gas content to develop 142 individual "type wells" to reflect average, high and low performance for each major coal seam in each basin partition. 


\subsubsection{Basic Cost and Economic Model}

The study constructed a Powder River Basin coalbed methane cost and economic model, CECON (Coalbed Economics), to assess the economic feasibility of developing coalbed methane in the basin (discussed in Chapter 4). The model includes four components: (1) basic capital costs; (2) basic operating and maintenance costs; (3) gas transportation and compressions costs; and (4) other costs.

The economic model incorporates forecasts for future natural gas prices (at the Henry Hub), current and anticipated Wyoming "basin differentials," royalties, production taxes, and other factors that impact CBM costs and economics. The economic model is an industry standard discounted cash flow (DCF) model that provides both an internal rate of return and the net present value (NPV) of an investment at various discount rates and at various net gas prices.

\subsubsection{Water Management Alternatives}

Finally, the Basin Study examined the costs and economic feasibility of four alternatives for CBM produced water management in the Powder River Basin. These include:

1. Untreated or passively treated produced water, with surface discharge;

2. Infiltration impoundment of the produced water, with enhanced evaporation and/or land application;

3. Shallow re-injection of the produced water; and

4. Actively treated produced water (with reverse osmosis), with surface discharge of the treated water and with disposal of the residual concentrate by trucking and/or deep re-injection.

Deep re-injection of the untreated, relatively high quality CBM produced water would constitute a loss of a valuable resource and thus was not included among the water disposal alternatives addressed in this study.

\subsection{Summary of Findings and Impacts}

\subsubsection{The Powder River Basin coals contain a considerably larger volume of gas in place} than established by previous studies. Major reasons for the increased PRB coalbed methane resource in-place of 61 Tcf are: (1) the study included the deeper Fort Union coals prevalent in the basin, it compiled new data on the Wastach coals, and it included Montana coals; and (2) the study identified the presence of free gas in certain coal formations and established higher gas content values for PRB coals.

\subsubsection{A significant portion of the coalbed methane resource in the Powder River Basin is} technically recoverable. The estimate of $39 \mathrm{Tcf}$ of technically recoverable resources is based on reservoir modeling and the construction of 142 "type wells" representative of the distribution in well performance (gas and water production) in the basin. This updates earlier estimates by the Potential Gas Committee (2000) of 24 Tcf and by the U.S. Geological Survey (2002) of 14 Tcf. 
1.5.3 The costs and economic feasibility of further developing coalbed methane in the Powder River Basin will be significantly impacted by produced water management practices and requirements. As shown in Table 1-3, requiring active treatment of water (such as reverse osmosis) imposes a high cost penalty, and with it, loss of economically recoverable resources.

Table 1-3. Economically Recoverable CBM (Tcf)

\begin{tabular}{|l|c|c|c|c|}
\cline { 2 - 5 } \multicolumn{1}{c|}{} & \multicolumn{4}{c|}{ Alternative Water Disposal Options } \\
\hline Economic Cases & $\begin{array}{c}\text { Surface } \\
\text { Discharge }\end{array}$ & Impoundment & $\begin{array}{c}\text { Shallow } \\
\text { Reinjection }\end{array}$ & $\begin{array}{c}\text { Active } \\
\text { Treatment }\end{array}$ \\
\hline Case 1 (Today) & $1.5 \mathrm{Tcf}$ & -- & -- & -- \\
\hline Case 2 (Transition) & & $20.0 \mathrm{Tcf}$ & $18.8 \mathrm{Tcf}$ & $7.1-10.2 \mathrm{Tcf}$ \\
\hline Case 3 (Long Term) & $22.4 \mathrm{Tcf}$ & $27.8 \mathrm{Tcf}$ & $27.1 \mathrm{Tcf}$ & $17.8-21.6 \mathrm{Tcf}$ \\
\hline
\end{tabular}

* Natural gas price (Henry Hub) of \$3 (real) per Mcf for life of project.

${ }^{* *}$ Basin differential remains at $\$ 1.80$ per Mcf.

${ }^{* * *}$ Basin differential narrows from $\$ 1.80$ per Mcf in year 1 to $\$ 0.80$ per Mcf in year 3 and beyond.

${ }^{* * * *}$ Basin differential is $\$ 0.80$ per Mcf.

The distribution of economically recoverable CBM and estimated water production by mineral ownership (using Case 2 economic conditions) is provided in Tables 1-4 and 1-5.

Table 1-4. Volumes of Economically Recoverable CBM (Tcf)

\begin{tabular}{|l|c|c|c|c|}
\cline { 2 - 5 } \multicolumn{1}{c|}{} & \multicolumn{3}{c|}{ Alternative Water Disposal Options } \\
\hline Mineral Ownership & $\begin{array}{c}\text { Surface } \\
\text { Discharge }\end{array}$ & Impoundment & $\begin{array}{c}\text { Shallow } \\
\text { Reinjection }\end{array}$ & $\begin{array}{c}\text { Active } \\
\text { Treatment }\end{array}$ \\
\hline Federal & $13.7 \mathrm{Tcf}$ & $12.2 \mathrm{Tcf}$ & $11.5 \mathrm{Tcf}$ & $4.3-6.2 \mathrm{Tcf}$ \\
\hline State & $1.5 \mathrm{Tcf}$ & $1.4 \mathrm{Tcf}$ & $1.3 \mathrm{Tcf}$ & $0.5-0.7 \mathrm{Tcf}$ \\
\hline Private & $7.2 \mathrm{Tcf}$ & $6.4 \mathrm{Tcf}$ & $6.0 \mathrm{Tcf}$ & $2.3-3.3 \mathrm{Tcf}$ \\
\hline TOTAL & $22.4 \mathrm{Tcf}$ & $20.0 \mathrm{Tcf}$ & $18.8 \mathrm{Tcf}$ & $7.1-10.2 \mathrm{Tcf}$ \\
\hline
\end{tabular}

All mineral ownership results based on a simplified methodology using draft EIS data. 
Table 1-5. Volumes of CBM Produced Water (Billion Bbls)

\begin{tabular}{|l|c|c|c|c|}
\cline { 2 - 5 } \multicolumn{1}{c|}{} & \multicolumn{4}{c|}{ Alternative Water Disposal Options } \\
\hline Mineral Ownership & $\begin{array}{c}\text { Surface } \\
\text { Discharge }\end{array}$ & Impoundment & $\begin{array}{c}\text { Shallow } \\
\text { Reinjection }\end{array}$ & $\begin{array}{c}\text { Active } \\
\text { Treatment }\end{array}$ \\
\hline Federal & 16.6 & 14.6 & 13.8 & $3.7-6.5$ \\
\hline State & 1.9 & 1.7 & 1.6 & $0.4-0.8$ \\
\hline Private & 8.7 & 7.7 & 7.3 & $2.0-3.4$ \\
\hline TOTAL & $27.2^{*}$ & 24.0 & 22.7 & $6.1-10.7$ \\
\hline
\end{tabular}

${ }^{*}$ Approximately 5 billion barrels less water than estimated in the WY draft EIS.

1.5.4 More stringent CBM produced water management practices will lead to loss of recoverable CBM resources for federal, state and local mineral ownership. The loss of recoverable CBM resources by mineral ownership due to progressively more stringent CBM produced water management practices (using Case 2 economic conditions) is provided in Table 1-6.

Table 1-6. Loss of Economically Recoverable CBM (Tcf)

\begin{tabular}{|l|c|c|c|c|}
\cline { 2 - 5 } \multicolumn{1}{c|}{} & \multicolumn{4}{c|}{ Alternative Water Disposal Options } \\
\hline Mineral Ownership & $\begin{array}{c}\text { Surface } \\
\text { Discharge* }\end{array}$ & Impoundment & $\begin{array}{c}\text { Shallow } \\
\text { Reinjection }\end{array}$ & $\begin{array}{c}\text { Active } \\
\text { Treatment }\end{array}$ \\
\hline Federal & & $(1.5 \mathrm{Tcf})$ & $(2.2 \mathrm{Tcf})$ & (7.5-9.4 Tcf) \\
\hline State & & $(0.1 \mathrm{Tcf})$ & $(0.2 \mathrm{Tcf})$ & (0.8-1.0 Tcf) \\
\hline Private & & $(0.8 \mathrm{Tcf})$ & $(1.2 \mathrm{Tcf})$ & (3.9-4.9 Tcf) \\
\hline TOTAL & & $(2.4 \mathrm{Tcf})$ & (3.6 Tcf) & (12.2-15.3 Tcf) \\
\hline
\end{tabular}

* An estimated 22.4 Tcf of economically recoverable CBM resource is available under Case 2 economic conditions and surface discharge.

1.5.5 More stringent CBM produced water management practices will reduce royalty collections and state severance and ad valorem tax receipts. Federal, state and private royalty payments average about $\$ 0.26 / \mathrm{Mcf}$ (assuming Case 2 economic conditions). The aggregate royalty payment losses would range from $\$ 506$ to $\$ 3,184$ million depending on the water management practice required, shown on Table 1-7. 
Table 1-7. Loss of Mineral Royalties from CBM (\$MM)

\begin{tabular}{|l|c|c|c|c|}
\cline { 2 - 5 } \multicolumn{1}{c|}{} & \multicolumn{4}{c|}{ Alternative Water Disposal Options } \\
\hline Mineral Ownership & $\begin{array}{c}\text { Surface } \\
\text { Discharge* }\end{array}$ & Impoundment & $\begin{array}{c}\text { Shallow } \\
\text { Reinjection }\end{array}$ & $\begin{array}{c}\text { Active } \\
\text { Treatment }\end{array}$ \\
\hline Federal & & $(\$ 268)$ & $(\$ 401)$ & $(\$ 1,349-1,687)$ \\
\hline State & & $(\$ 41)$ & $(\$ 61)$ & $(\$ 207-\$ 258)$ \\
\hline Private & & $(\$ 197)$ & $(\$ 294)$ & $(\$ 991-\$ 1,239)$ \\
\hline TOTAL & & $(\$ 506)$ & $(\$ 756)$ & $(\$ 2,547-\$ 3,184)$ \\
\hline
\end{tabular}

${ }^{*} A$ total of $\$ 4,659$ million of mineral royalties would be collected under Case 2 economic conditions and surface discharge.

State severance and county ad valorem tax receipts average about $\$ 0.15 /$ Mcf (assuming Case 2 economic conditions and 12\% (WY) and 9.3\% (MT) tax rates). The aggregate tax receipt losses range from $\$ 360$ to $\$ 2,270$ million depending on the water management practices required.

1.5.6 More stringent CBM produced water management practices will lead to less capital investment and service work in the Powder River Basin. The loss of CBM well drilling and capital investment by mineral ownership due to more stringent CBM produced water management practices (using Case 2 economic conditions) is provided in Tables 1-8 and 1-9.

Table 1-8. Loss of Well Drilling for CBM (\# Wells)

\begin{tabular}{|l|c|c|c|c|}
\cline { 2 - 5 } \multicolumn{1}{c|}{} & \multicolumn{4}{c|}{ Alternative Water Disposal Options } \\
\hline Mineral Ownership & $\begin{array}{c}\text { Surface } \\
\text { Discharge* }\end{array}$ & $\begin{array}{c}\text { Shallow } \\
\text { Impoundection }\end{array}$ & $\begin{array}{c}\text { Active } \\
\text { Treatment }\end{array}$ \\
\hline Federal & & $(4,041)$ & $(6,324)$ & $(17,919-21,257)$ \\
\hline State & & $(464)$ & $(726)$ & $(2,056-2,439)$ \\
\hline Private & & $(2,120)$ & $(3,318)$ & $(9,940-11,151)$ \\
\hline TOTAL & & $(6,625)$ & $(10,368)$ & $(29,915-34,847)$ \\
\hline
\end{tabular}

* An estimated 46,944 wells would be drilled under Case 2 economic conditions and surface discharge. This represents more than 4,000 fewer wells compared to the WY draft EIS well-count estimate. 
Table 1-9. Loss of Capital Investment for CBM (\$MM)

\begin{tabular}{|l|c|c|c|c|}
\cline { 2 - 5 } \multicolumn{1}{c|}{} & \multicolumn{3}{c|}{ Alternative Water Disposal Options } \\
\hline Mineral Ownership & $\begin{array}{c}\text { Surface } \\
\text { Discharge* }\end{array}$ & $\begin{array}{c}\text { Shallow } \\
\text { Impoundment }\end{array}$ & $\begin{array}{c}\text { Active } \\
\text { Reinjection }\end{array}$ & \begin{tabular}{c} 
Treatment \\
\hline Federal
\end{tabular} \\
\hline State & & $(\$ 455)$ & $(\$ 712)$ & $(\$ 2,016-\$ 2,391)$ \\
\hline Private & & $(\$ 52)$ & $(\$ 82)$ & $(\$ 231-\$ 274)$ \\
\hline TOTAL & & $(\$ 238)$ & $(\$ 373)$ & $(\$ 1,058-\$ 1,255)$ \\
\hline
\end{tabular}

* The capital expenditure for PRB CBM is estimated at \$5,281 million assuming Case 2 economic conditions and surface discharge.

\subsubsection{Summary of Impacts. The loss of CBM resources, royalties and tax receipts from} more stringent CBM produced water management practices would be substantial. Table 1-10 provides a summary of the potential losses that would occur from use of progressively more stringent water disposal alternatives.

Table 1-10. Summary of Impacts

\begin{tabular}{|l|c|c|c|}
\hline \multirow{2}{*}{ Water Disposal Method } & $\begin{array}{c}\text { Loss of CBM } \\
\text { Resource }\end{array}$ & $\begin{array}{c}\text { Loss of CBM } \\
\text { Royalty }\end{array}$ & $\begin{array}{c}\text { Loss of } \\
\text { Production/ } \\
\text { Ad Valorem Taxes }\end{array}$ \\
\cline { 2 - 4 } & $\mathbf{( T c f )}$ & $\mathbf{( \$ \text { million) }}$ & (\$ million) \\
\hline Surface Discharge & -- & -- & -- \\
\hline Infiltration Impoundment & $(2.4)$ & $(\$ 506)$ & $(\$ 362)$ \\
\hline Shallow Re-injection & $(3.6)$ & $(\$ 756)$ & $(\$ 540)$ \\
\hline Reverse Osmosis/w: & \multicolumn{3}{|c|}{} \\
\hline - Trucking of Residual & $(15.3)$ & $(\$ 3,184)$ & $(\$ 2,272)$ \\
\hline - Deep Disposal of Residual & $(12.2)$ & $(\$ 2,547)$ & $(\$ 1,810)$ \\
\hline
\end{tabular}

1.5.8 Improvements in coalbed methane production technology and water management practices would help maintain the economic viability of Powder River Basin coalbed methane. Advanced technology options offer promise for reducing costs and increasing reserves per well. Conducting assessments of these technology options and supporting their adaptation to PRB operating conditions would be of high value to basin operators. 


\subsection{GEOLOGIC SETTING AND RESERVOIR PROPERTIES}

\subsection{Basin Area}

The Powder River Basin is one of a series of coal-bearing basins along the Rocky Mountains, stretching from northern New Mexico to central Montana, Figure 2-1. The basin covers approximately 28,500 square miles, with approximately one-half of this area underlain by producible coals. The basin is bounded on the east by the Black Hills uplift, on the north by the Miles City arch, on the south by the Laramide Mountains, and on the west by the Big Horn uplift and Casper arch.

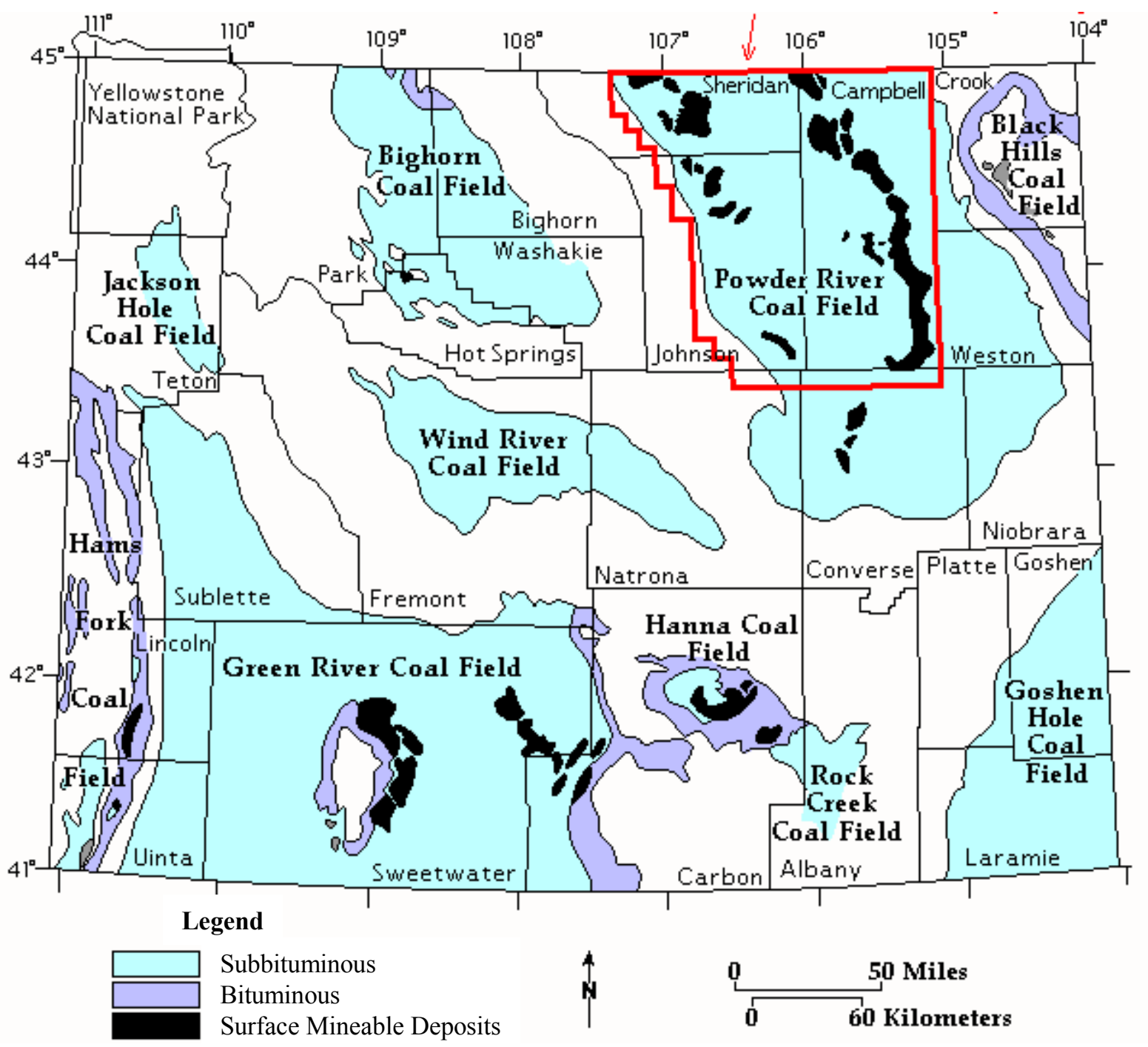

Figure 2-1. Coal Basins of Wyoming 
The bulk of coalbed methane activity to date has been in the east and central portion of the basin, around the town of Gillette, in Campbell County, Wyoming, Figure 2-2. To date, nearly 12,000 coalbed methane wells have been drilled in the Powder River Basin, providing a wealth of data for establishing the geologic setting and characteristics of the Wasatch and Fort Union Formation low rank coals in this basin.

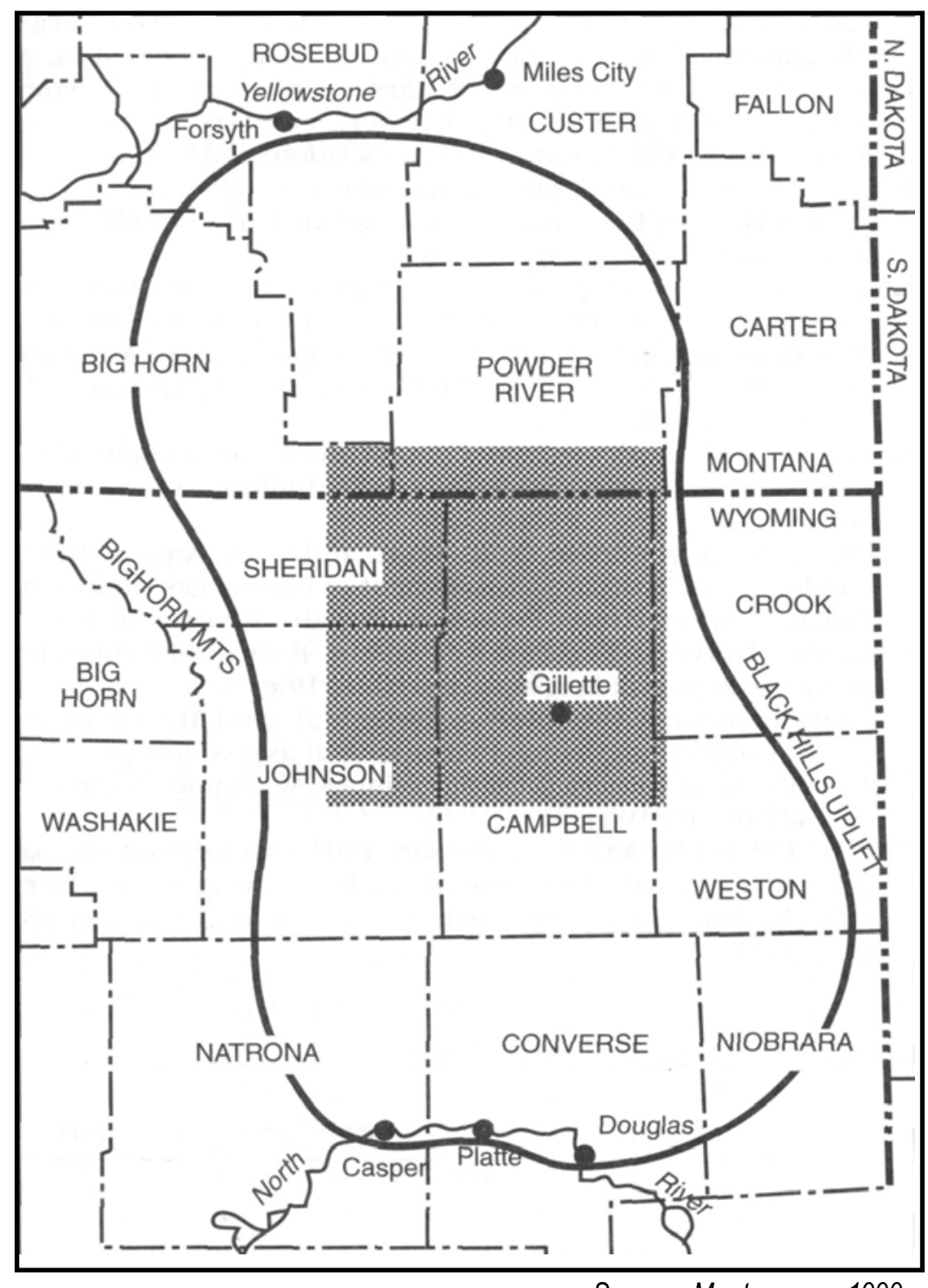

Source: Montgomery, 1999

Figure 2-2. Center of Powder River Basin Coalbed Methane Activity

\subsection{Basin Structure}

The eastern flank of the Powder River Basin dips gradually at an average of $1.5^{\circ}$ and is characterized by occasional normal faulting and folding, Figure 2-3. The basinal axis exists along the steeper western and southern margins, where the basin terminates against a complex of 


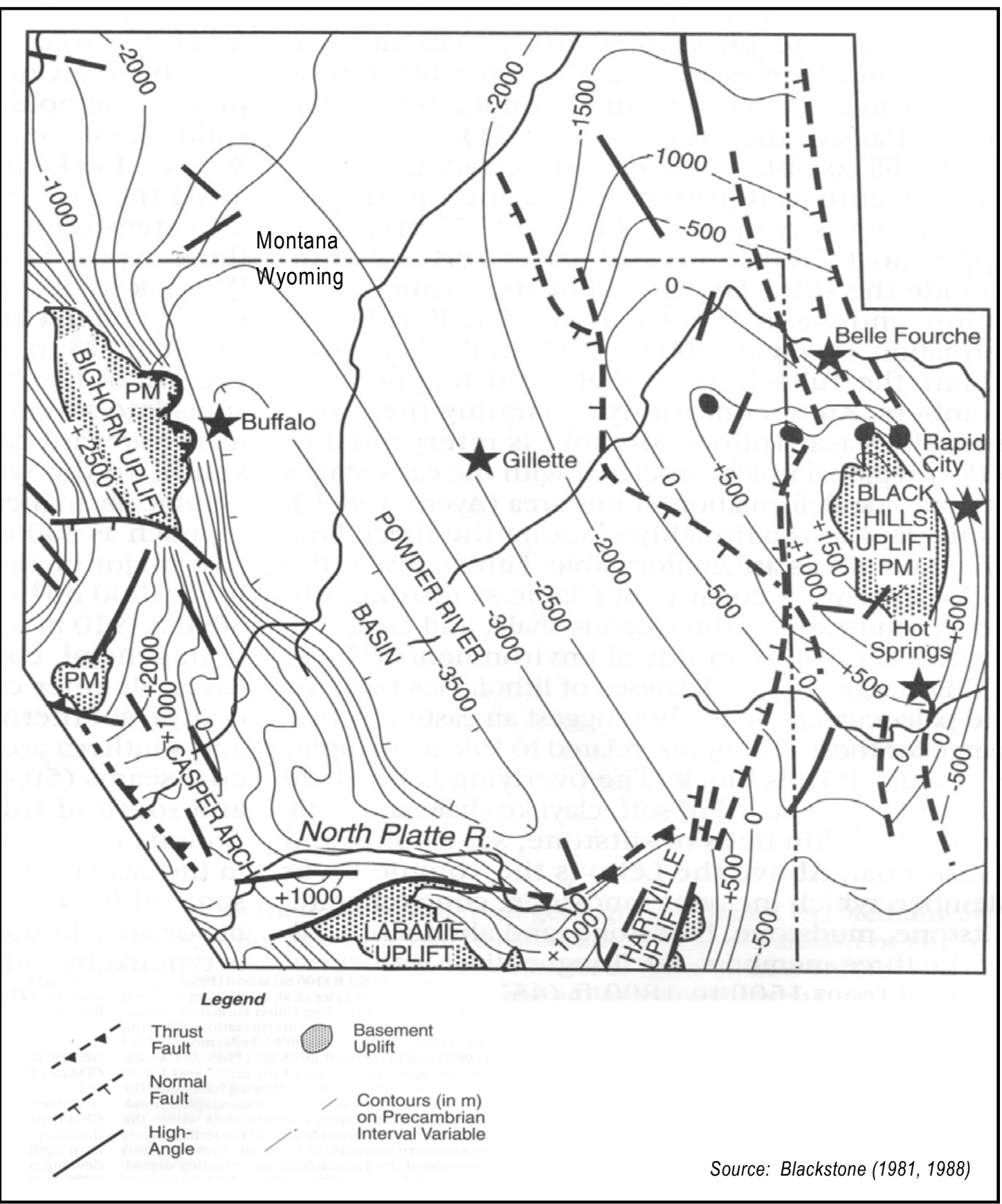

Figure 2-3. Regional Structure and Tectonic Map of the Powder River Basin

basement thrusts and reverse faults, as shown on the generalized cross-section of the Powder River Basin, Figure 2-4.

\subsection{Basin Stratigraphy}

The Powder River Basin is filled mainly with thick Tertiary-age marine and fluvial deposits. The Tertiary units contain the coal bearing Fort Union and Wasatch formations that are the topic of this Basin Study, Figure 2-5. 


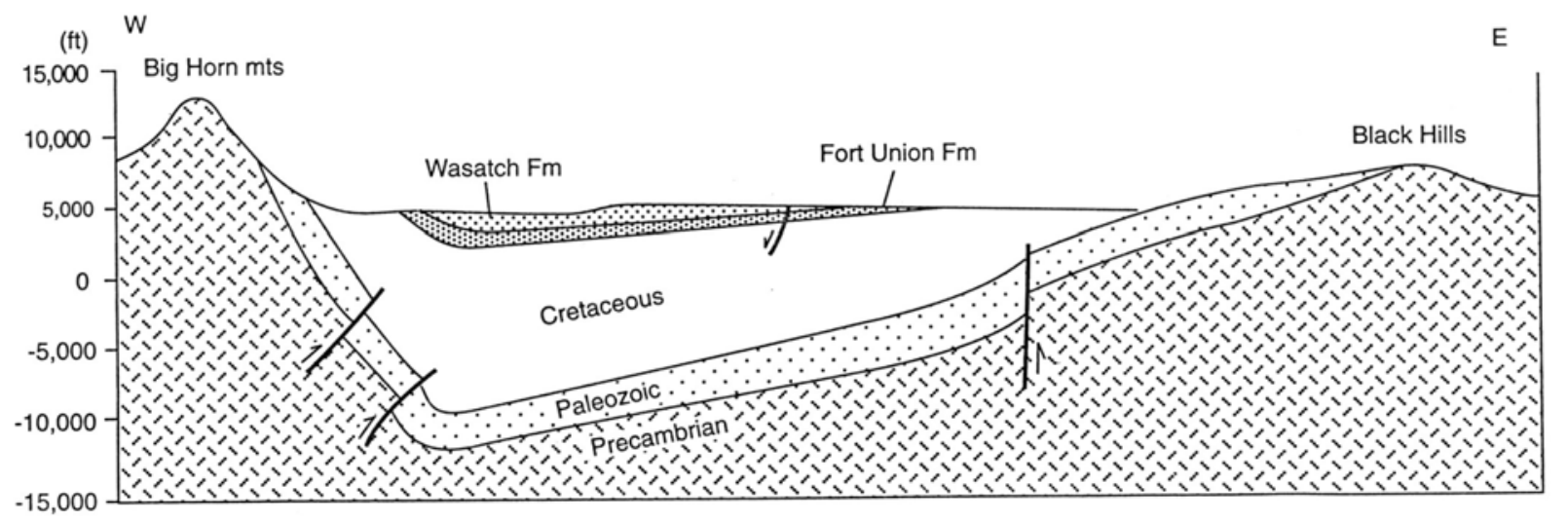

Figure 2-4. Regional Cross Section of the Powder River Basin

Source: Montgomery, 1999.

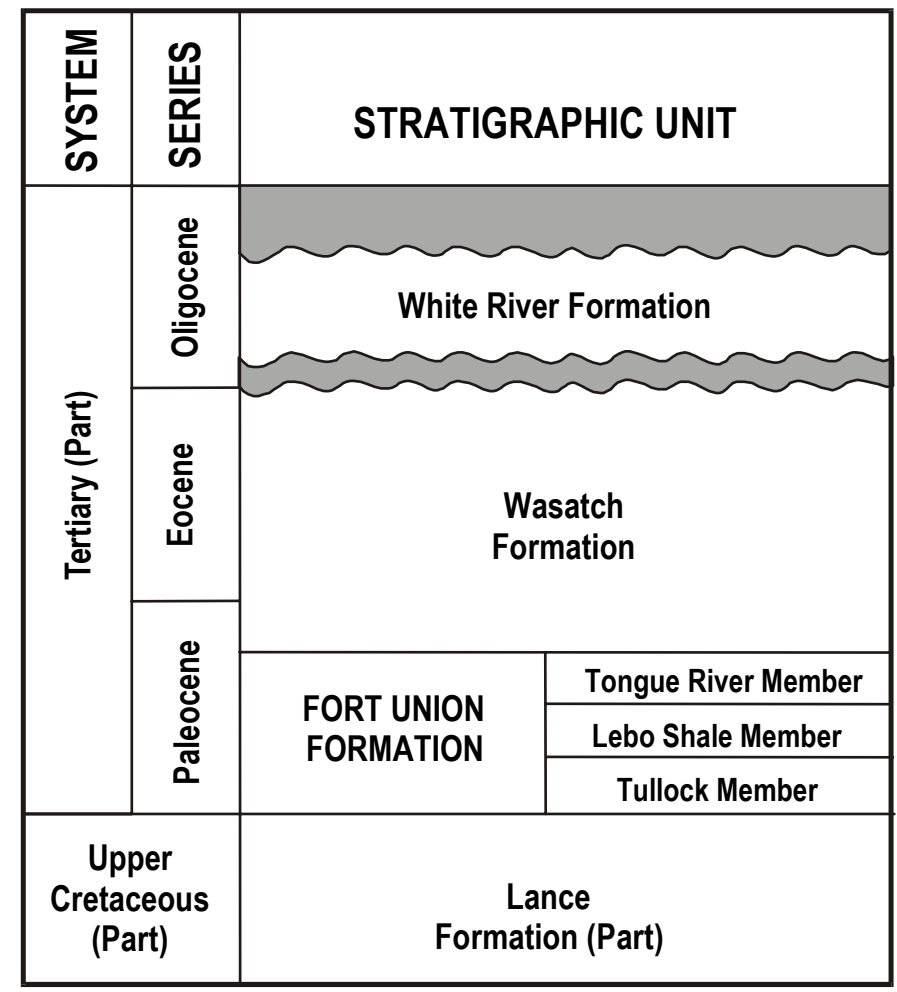

Source: Law, Rice and Flores, 1991

Figure 2-5. Upper Cretaceous and Tertiary Stratigraphic Chart for Powder River Basin

The Tongue River Member, consisting of sandstone, conglomerate, siltstone, limestone and coal, is the principal coal-bearing unit of the Fort Union Formation. The Tongue River Member contains a large number of distinct coal seams, ranging from a few feet to over 200 feet in thickness, as shown on Figure 2-6. 


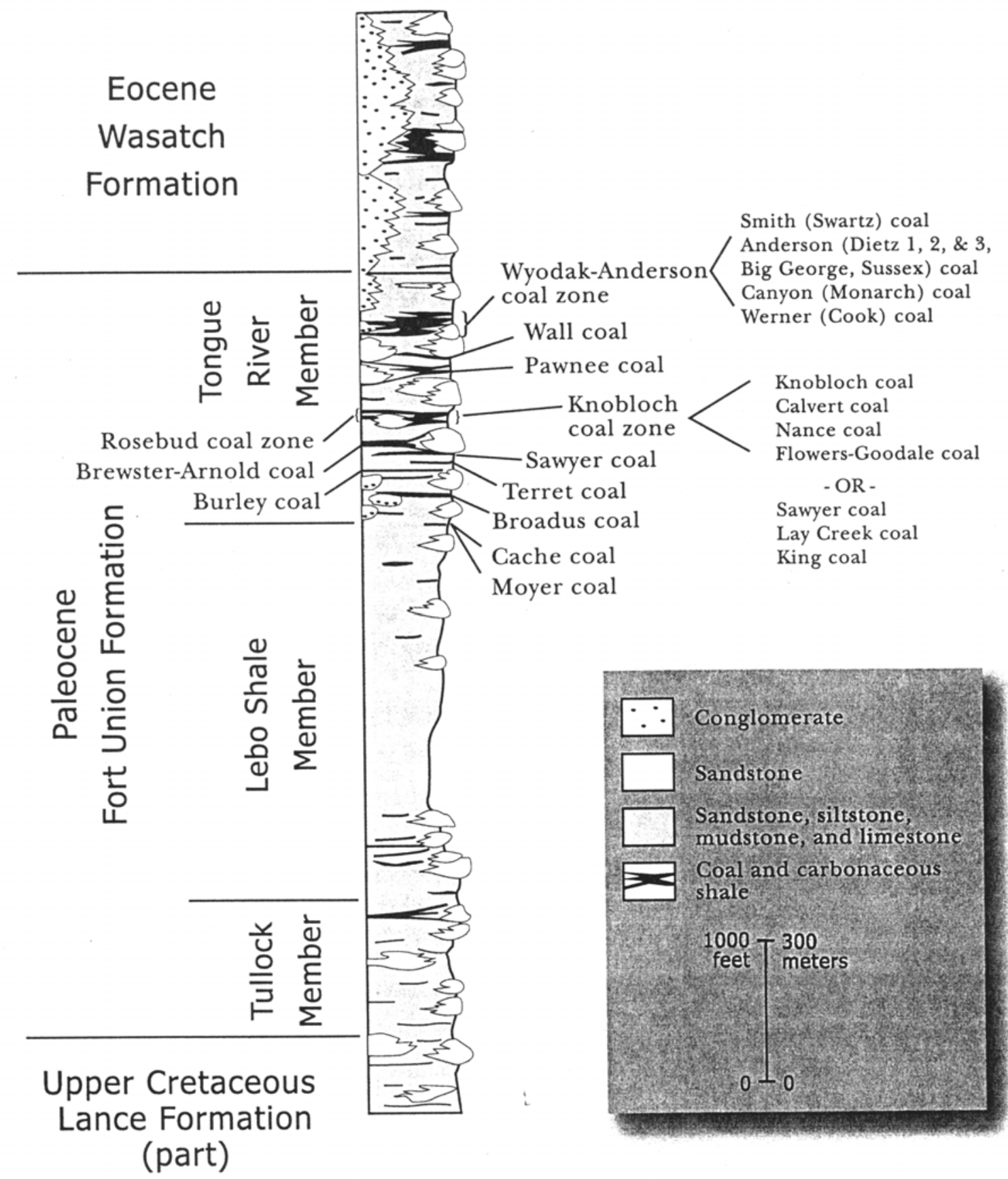

Figure 2-6. Coal Bearing Units of the Tongue River Member of the Fort Union Formation

The Tongue River Member can be further divided into upper and lower units. The Upper Tongue River unit contains the Smith/Swartz, Anderson (Deitz), Canyon (Monarch), Wyodak (where the Anderson and Canyon have merged), the Big George and the Cook (Carney) seams. The Lower Tongue River unit contains the Wall, Pawnee and Cache seams. 
A series of Wasatch Formation coals exist on the western edge of the basin and include the Cameron, Felix and Ucross seams. These coals coalesce into a thick coal package at Lake Desmet.

\subsection{Major Coal Seams}

The coals are exposed along the eastern edge of the basin where they are surface mined. The thickest exposed unit of coal along the east-central portion of the basin is the Wyodak seam, containing several individual coal units. As shown on Figure 2-7, the Wyodak seam splits into several thinner coal seams, such as the Anderson and Canyon, toward the basin center as well as to the north and south. Figure 2-8 provides a log of the major coals of the Upper Tongue River unit in the east-central portion of the basin.

A series of informal names have been assigned to the coals in the Powder River Basin, creating stratigraphic uncertainty. The Basin Study strives to use a consistent set of coal seam terminology, following the extensive stratigraphic work by Goolsby, Finley and Associates. The distribution and correlation of the coals in the Powder River Basin is shown in Figure 2-9, an east-west cross section of the basin.

\subsection{Key Reservoir Properties}

A series of reservoir properties, including depth, coal thickness, gas content, pressure gradient and gas saturation, were collected and assessed to calculate the gas in-place for each of the major coals in each of the 12 basin partitions. In addition, data on coal fracture and matrix porosity was established to calculate the volume of water in-place for each of the coals. Finally, coal reservoir permeability (for both the cleat system and the coal matrix) was established to calculate the amounts of recoverable methane and water.

\subsubsection{Coal Seam Depth}

Coal depth data from completed wells and from previous studies were used to build the coal depth data base for the Powder River Basin. Information on the depth of individual coal seams is provided in Chapter 6. Shown below is data on coal depth for basin Partition \#4.

Table 2-1. Partition \#4 Coal Depth

\begin{tabular}{|l|c|c|}
\hline \multicolumn{1}{|c|}{ Coal Seam } & Avg. Depth (ft) & Depth Range (ft) $^{*}$ \\
\hline Anderson & 450 & $300-650$ \\
\hline Canyon & 540 & $300-800$ \\
\hline Wyodak & 600 & $330-750$ \\
\hline Cook & 790 & $600-930$ \\
\hline Wall & 1,020 & $800-1,250$ \\
\hline Pawnee & 1,300 & $1,150-1,500$ \\
\hline Cache & 1,500 & $1,150-1,750$ \\
\hline
\end{tabular}

* Top of coal 


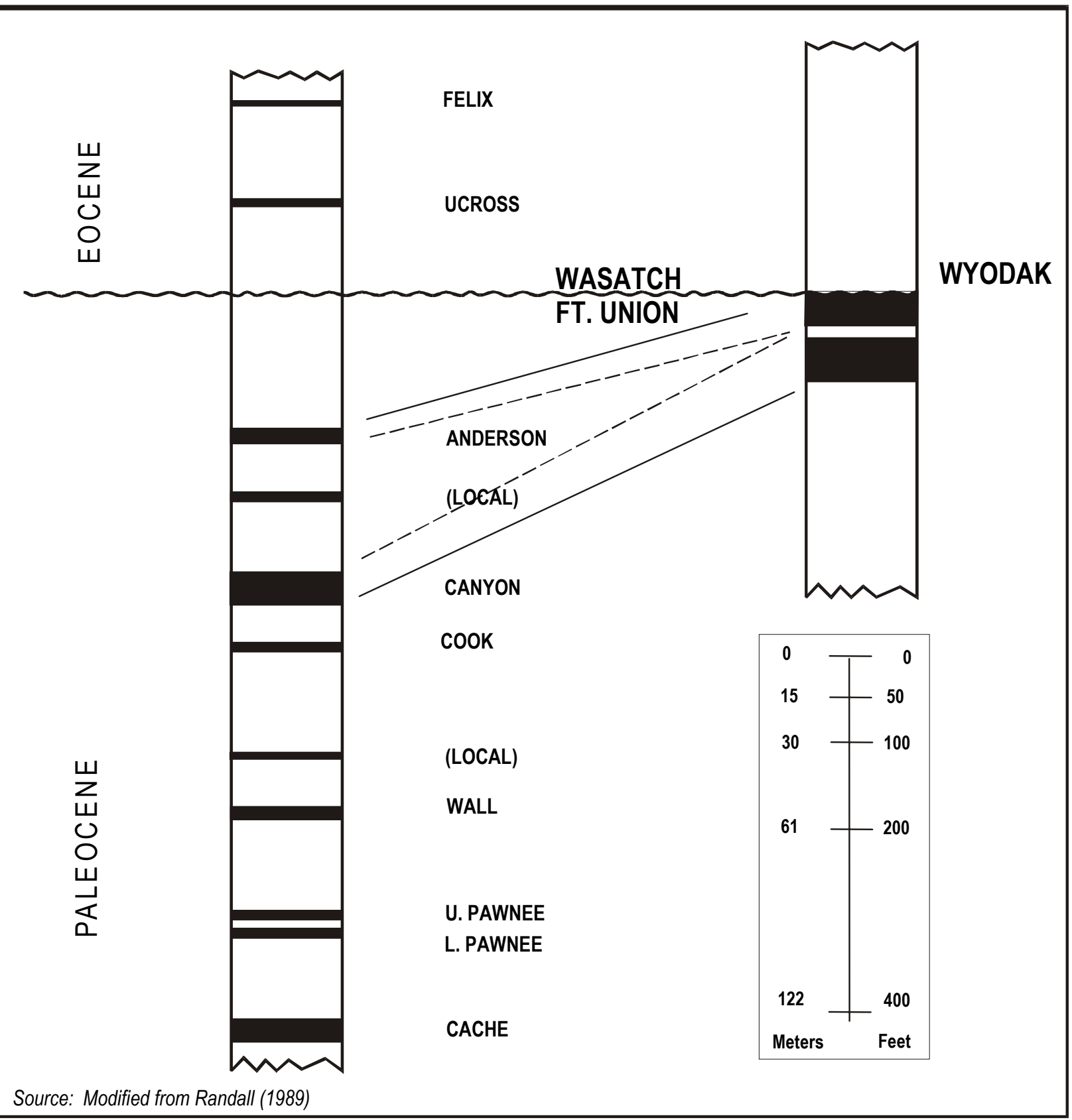

Figure 2-7. Simplified Representation of Fort Union Coalbeds Near Gillette, in Campbell County, Wyoming 


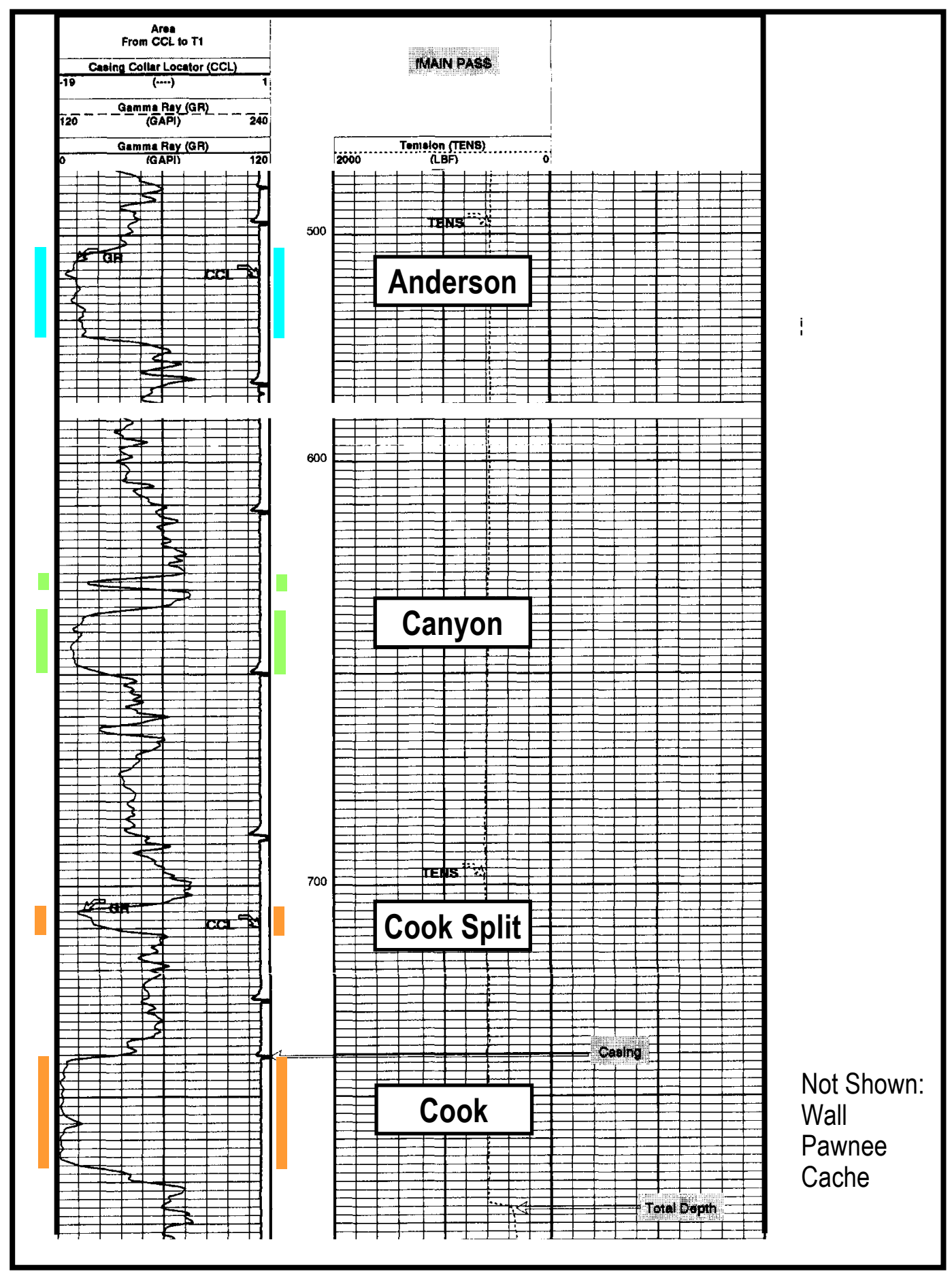

Figure 2-8. Sample Log - Upper Fort Union Coals in Partition \#4 


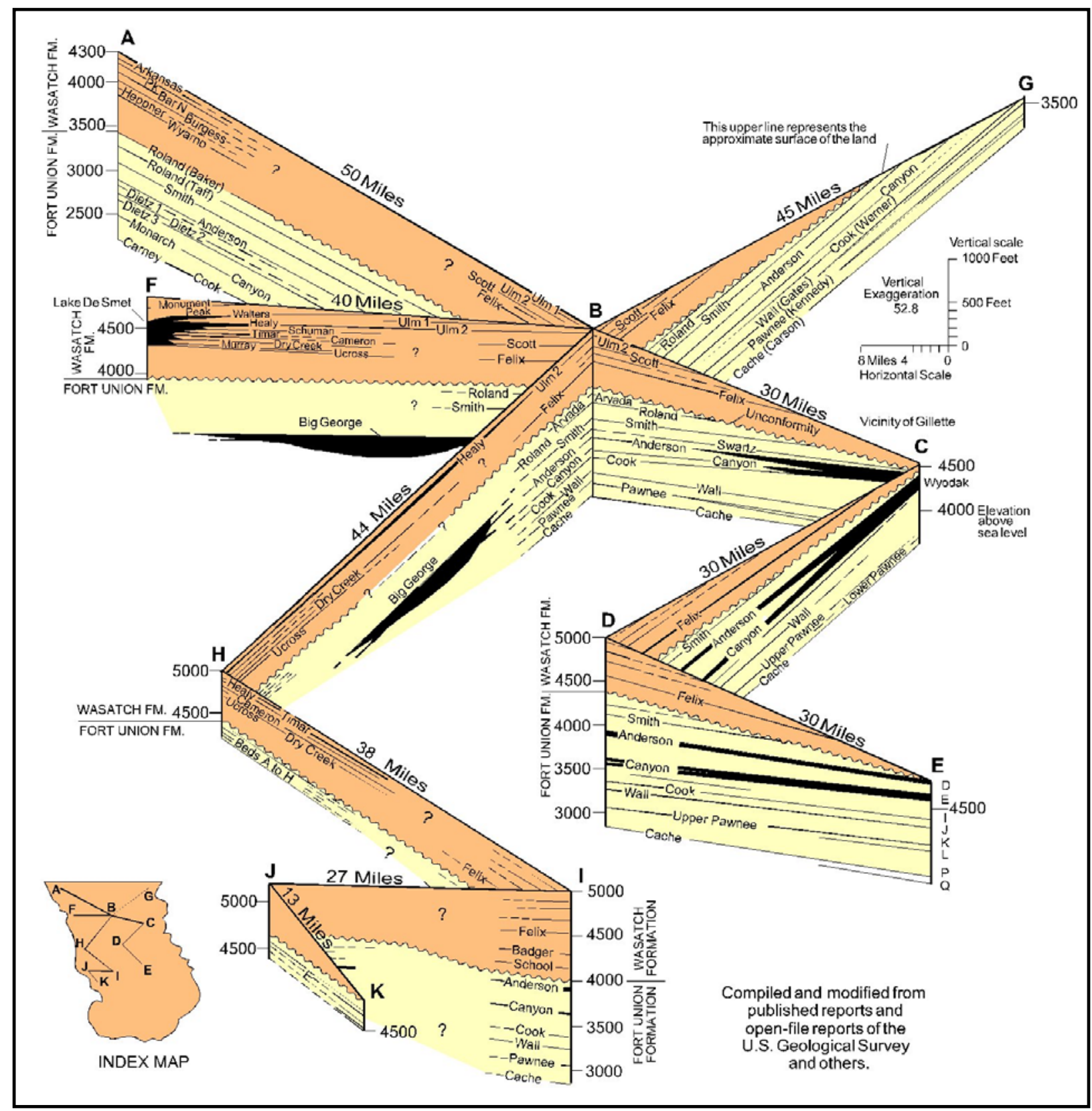

Source: Law, Rice and Flores, 1991

Figure 2-9. Coal Correlation Diagram for Fort Union and Wasatch Formation, Powder River Basin, Wyoming

\subsubsection{Coal Seam Thickness}

Coal seam thickness (net pay) was established for each major coal throughout the basin. Coal interval data from completed wells, well logs from WOGCC, and coal thickness data from previous studies (particularly the work by Goolsby, Findley and Associates and the USGS in PP 1625A) were used to build the coal thickness data base for the Powder River Basin (PRB). 
Information on thickness of individual coal seams is provided in Chapter 6. Shown below is data on coal thickness for basin Partition \#4. Figure 2-10 provides a cross section showing the complexity of coal deposition for the Wyodak group of coals along the eastern portion of the PRB.

Table 2-2. Coal Thickness for Partition \#4

\begin{tabular}{|l|c|c|}
\hline \multicolumn{1}{|c|}{ Coal Seam } & Avg. Thickness $(\mathrm{ft})$ & Thickness Range (ft) \\
\hline Anderson & 30 & $20-50$ \\
\hline Canyon & 35 & $20-50$ \\
\hline Wyodak & 73 & $70-80$ \\
\hline Cook & 31 & $20-50$ \\
\hline Wall & 27 & $20-40$ \\
\hline Pawnee & 27 & $25-30$ \\
\hline Cache & 23 & $20-30$ \\
\hline
\end{tabular}

\subsubsection{Regional Pressure Gradient}

A regional pressure gradient versus depth function for PRB coal seams, Figure 2-11, was constructed to establish reservoir pressure for each of the coal formations. This was assembled using:

- $\quad$ Detailed hydrology data and pressure mapping by the Wyoming BLM,

- Actual pressure data from basin producers, and

- $\quad$ History matching (using COMET3) of the pressure gradient data using long-term (4+ year) gas and water production data in the PRB.

The regional pressure gradient function shows that the shallower coals are significantly underpressured and approach normal hydrostatic pressures as the coals become deeper, Figure 2-12.

\subsubsection{Gas Content}

The Basin Study assembled available gas content data and adsorption isotherms, appropriate for the low rank coals of the PRB, from the following sources:

- $\quad$ Past gas content data collected by the BLM and published gas content and isotherm data by industry and the USGS,

- Advanced Resources' own gas content and isotherm data collected for analogous low rank coals in other basins, and

- $\quad$ History matching (using COMET3) of alternative isotherms using long-term (4+year) gas and water production data in the PRB. 


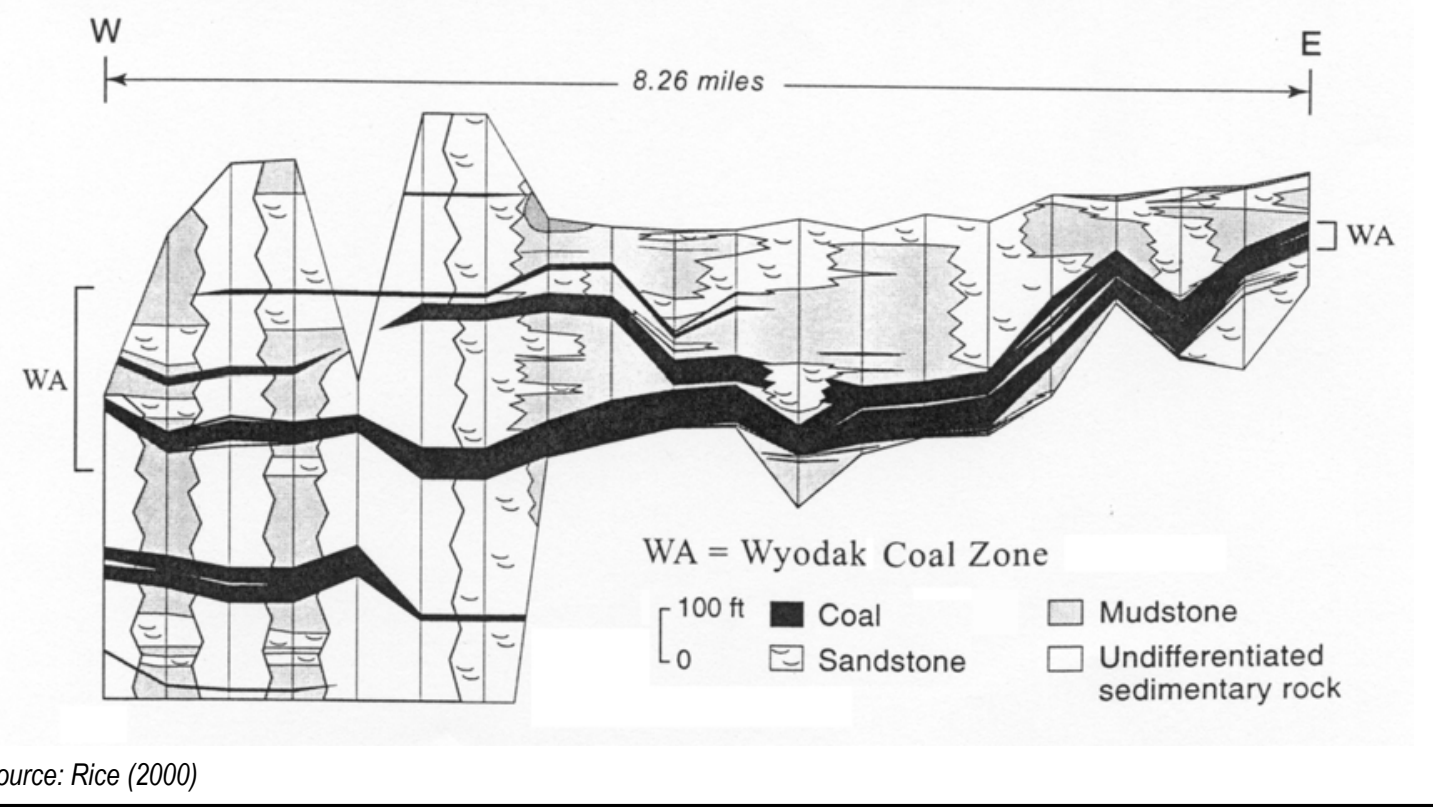

Figure 2-10. Cross-Section Showing Lateral Variation of Coalbeds in the Wyodak Coal Zone

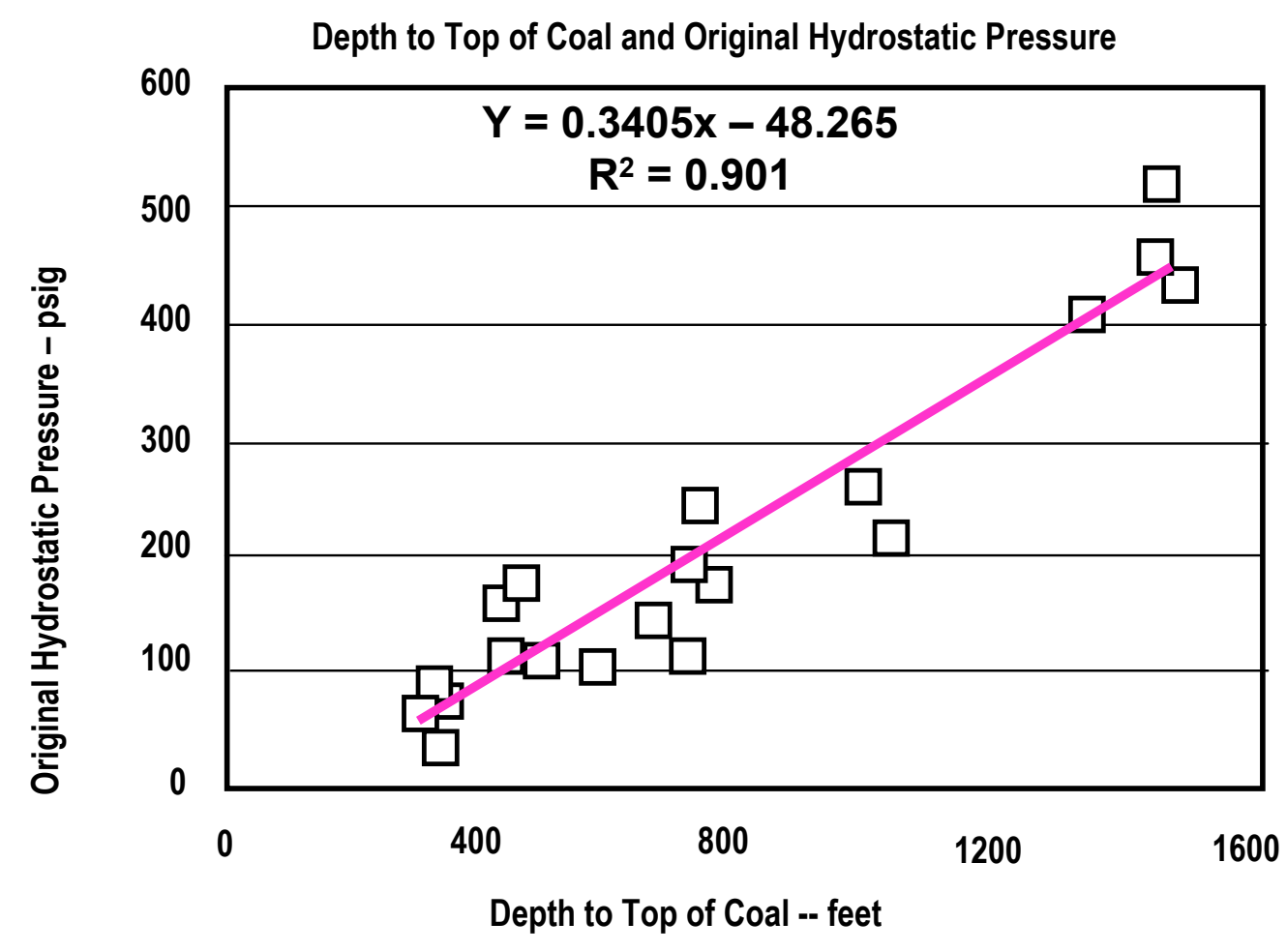

Source: Data from BLM files and CBM operators. Data from water monitor and CBM wells.

Figure 2-11. Regional Pressure Gradient 


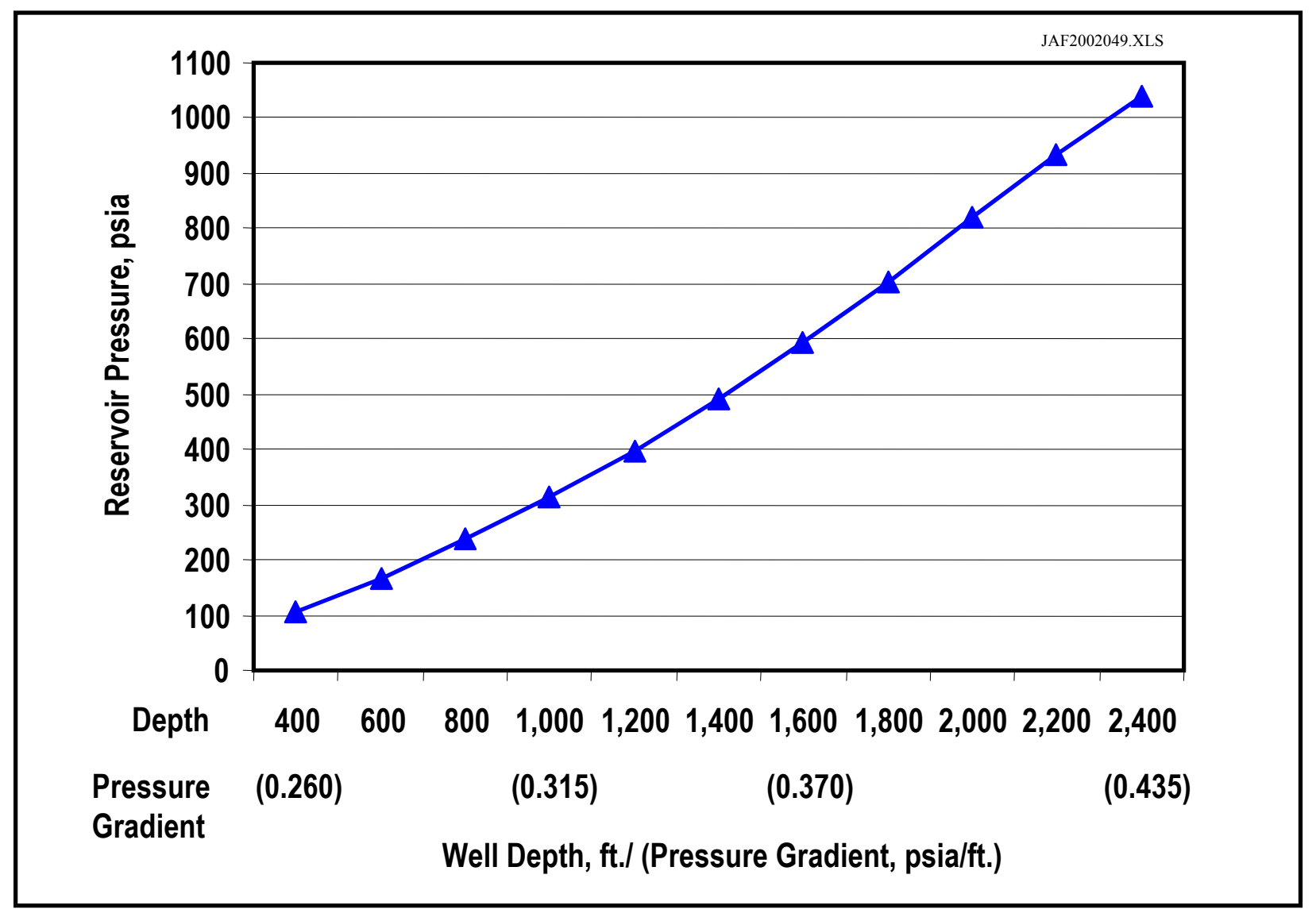

Figure 2-12. Reservoir Pressure Profile Used for PRB Study

The best fit coalbed methane isotherm was from actual gas content and isotherm data collected on an analogous overseas low rank coal basin, Figure 2-13. As a point of comparison, Figure 2-14 provides the average synthesized adsorption isotherm for coal in the PRB assembled from older data.

\subsubsection{Gas Saturation}

The nature of early time water and gas production was used to establish whether the PRB coals were undersaturated, fully saturated or contained free gas in the pore space:

- A series of fourteen individual coal seams and partition data sets, shown on Table 2-1, were assembled involving gas and water production data from over 1,400 PRB CBM wells.

- $\quad$ History matching (using COMET3) of production data was used to establish the level of gas saturation and presence of free gas in the coal cleat and matrix system. 


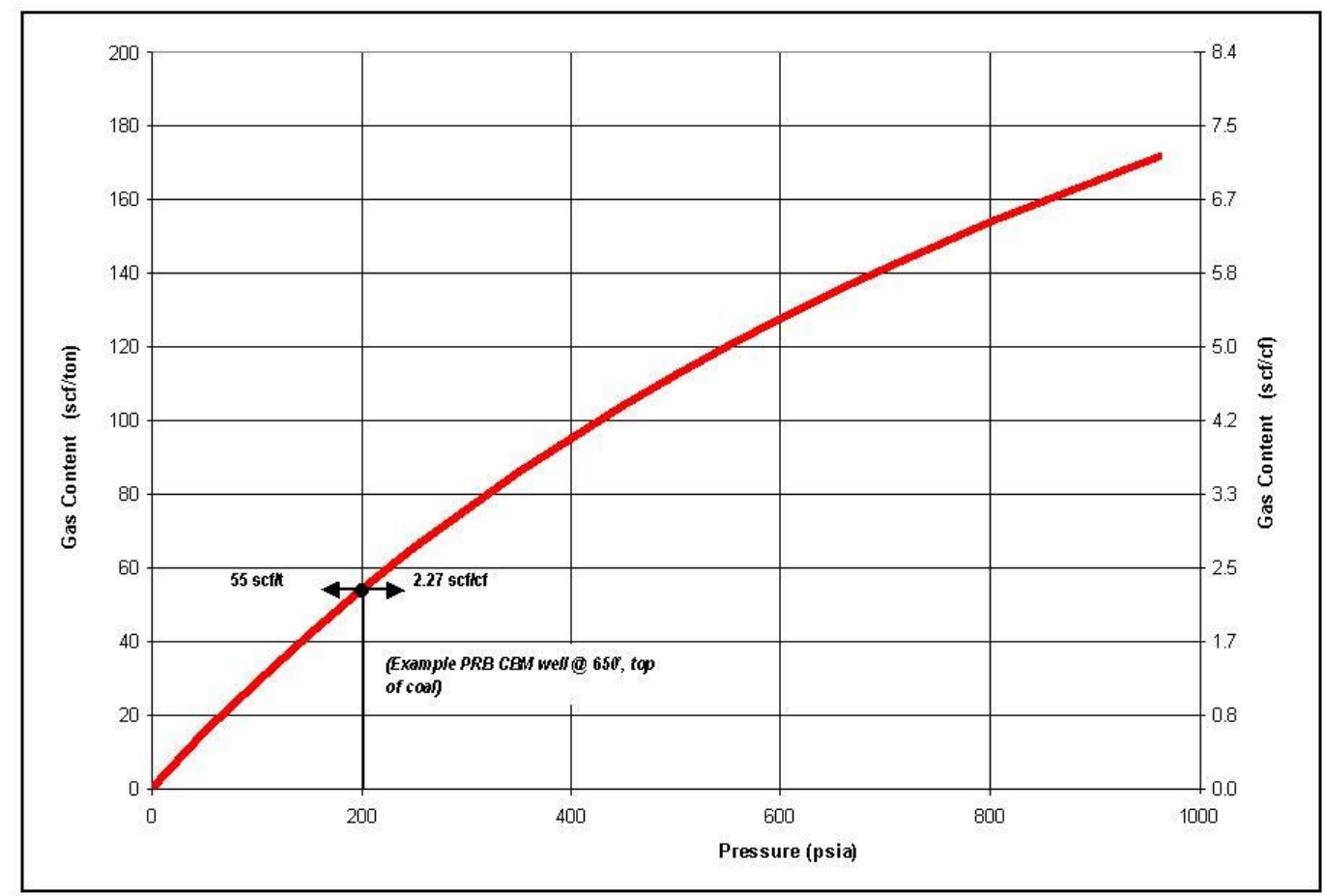

Figure 2-13. Gas Content Isotherm Used for Powder River Coalbed Methane

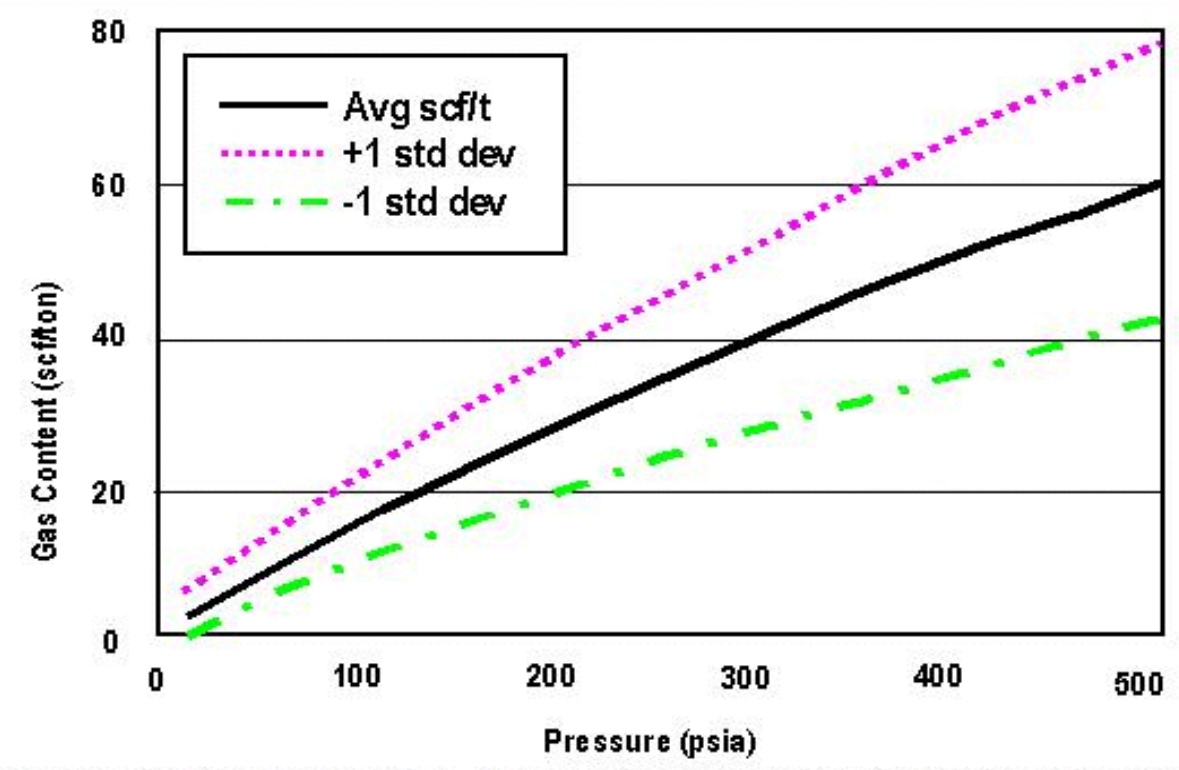

Source: From Wyoming EIS support documents. Average synthesized adsorption is othem for 41 coals amples from the $P R B$, based on a compilation of data from public and private sources.

Figure 2-14. Average Synthesized Adsorption Isotherm for 41 Coal Samples From the PRB, Based on a Compilation of Data From Public and Private Sources 
Overall, the study established that the coals are fully saturated with methane (at the reduced reservoir pressure conditions that generally exist in the basin) and that modest amounts of free gas exist in the matrix porosity and coal cleat (fracture) porosity systems in certain seam/partition data sets. However, operators report that low gas contents and severe undersaturation conditions may exist for certain deeper coals in the portions of the basin, south of Gillette. Collection and analysis of additional gas content data would help define their potential problem areas and seams in the basin.

Further discussion of the topics of gas content and gas saturation in the Powder River Basin is provided as Appendix A.

\subsubsection{Coal Fracture and Matrix Porosity}

History matching of water production was used to estimate the fracture and matrix porosity for the PRB coals:

1. In general, the coal cleat (fracture) porosity in the coals ranges from $0.1 \%$ to $1 \%$, consistent with other data (The Big George coal in Partition \#5 has an apparently higher than usual fracture porosity).

2. The matrix porosity for these low rank coals varies widely, ranging from $1 \%$ to $10 \%$. Matrix porosity tends to increase for the deeper coals, such as the Wall, Pawnee, and Cache.

High coal matrix porosities would support the relatively high water production from otherwise thinner (25 to 30 feet) coal seams, such as the Wall. As an alternative explanation, some investigators have put forward the concept of aquifers in the Fort Union Formation as providing and supporting the high water production observed from PRB coals.

Some amount of water influx or aquifer leakage from associated sands no doubt exists in some portions of the basin. However, our assessment is that porosity in these low rank coals is the primary source of the produced water and that aquifer recharge, if and where it does exist, is relatively modest for the following reasons:

- $\quad$ First, high matrix porosity values have been documented for other low rank coals (such as the overseas low rank coal used for the gas sorption isotherm, discussed above). Seidle (2002), in his review of selected coalbed methane pilots, cites a value of $10 \%$ for the porosity of the Wyodak coal at the Rawhide Butte Field of the Powder River Basin. Cox (2000), in his assessment of aquifer controls on CBM in the PRB, used 5\% for the Anderson-Wyodak coal.

- $\quad$ Second, the water production rates in the coalbed methane wells along the maturely developed eastern portion of the Powder River Basin (such as the Canyon coal wells Partition \#4) have declined to about 20 to 30 barrels per day at the end of 3 years from about 300 barrels per day during year 1 . And, some coal wells in the area have stopped producing any appreciable water. If aquifer leakage is occurring in this area, it would have to be low. 
- Third, the pressure response and gas desorption rates would be considerably different for water held in coal porosity versus water influx from aquifer leakage. The assessment of gas production by reservoir simulation tended to support the coal matrix as the primary source of the produced water, although separating porosity source water from low levels of aquifer leakage would be difficult to establish.

\subsubsection{Coal Permeability}

In general, the coal cleat (fracture) permeability of PRB coals is favorable, ranging from 35 to $500 \mathrm{md}$. Coal matrix permeabilities are considerably lower and variable, ranging from 0.001 to $1.0 \mathrm{md}$. However, even the lower end of the range for cleat and matrix permeabilities for the coals in the PRB is sufficient to support reasonable gas recoveries (in 10 years) of 50 to $80+\%$ of the gas in-place.

\subsection{Summary of Reservoir Properties}

Table 2-4 provides a summary of the key reservoir properties established from the geologic study and history matching of 14 sets of coalbed methane data representing the combined well performance of 1,428 coalbed methane wells in the Powder River Basin. Additional information on individual coal seam reservoir properties is provided in Chapter 6.

Shown below is the average derived data on coal seam gas content, pressure, gas saturation and porosity for basin Partition \#4.

Table 2-3. Average Data for Partition \#4

\begin{tabular}{|c|c|c|c|c|c|c|}
\hline \multirow{3}{*}{$\begin{array}{l}\text { Coal } \\
\text { Seam }\end{array}$} & \multirow{2}{*}{$\begin{array}{c}\text { Gas } \\
\text { Content }\end{array}$} & \multirow{2}{*}{$\begin{array}{c}\text { Pressure } \\
\text { (Top of } \\
\text { Coal) }\end{array}$} & \multicolumn{2}{|c|}{ Free Gas Saturation } & \multicolumn{2}{|c|}{ Porosity } \\
\hline & & & Fracture & Matrix & Fracture & Matrix \\
\hline & $(c f / t)$ & (psi) & $(\%)$ & $(\%)$ & $(\%)$ & $(\%)$ \\
\hline Anderson & 40 & 141 & 8 & 10 & 0.2 & 1.5 \\
\hline Canyon & 47 & 171 & 7 & 7 & 0.4 & 3.0 \\
\hline Wyodak & 54 & 199 & 5 & 10 & 1.0 & 6.0 \\
\hline Cook ${ }^{*}$ & 67 & 257 & 0 & 1 & 0.1 & 2.4 \\
\hline Wall & 84 & 340 & 0 & 0 & 1.0 & 10.0 \\
\hline Pawnee** & 106 & 460 & 0 & 0 & 0.5 & 5.0 \\
\hline Cache $^{* *}$ & 121 & 558 & 0 & 0 & 0.5 & 5.0 \\
\hline
\end{tabular}




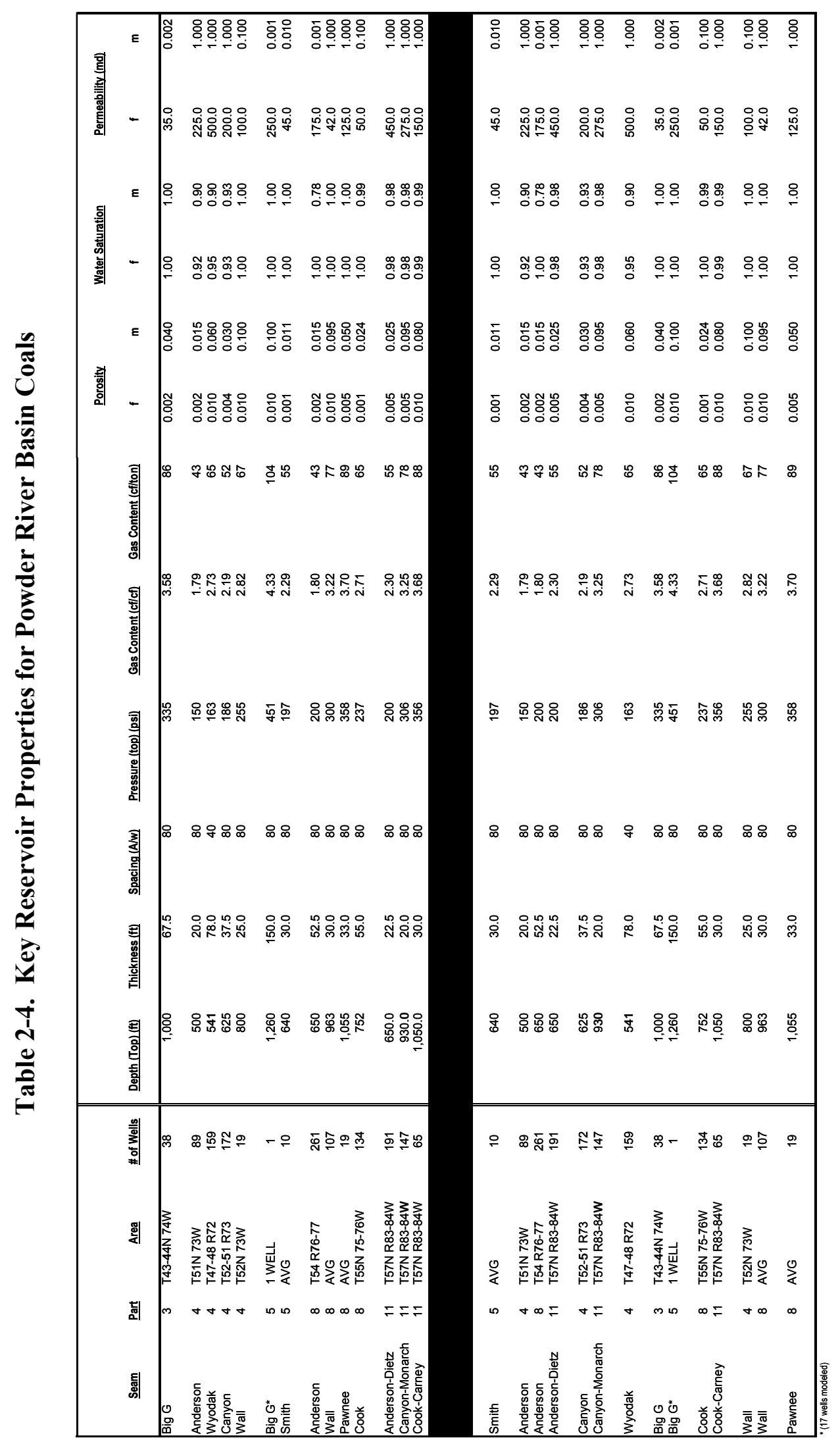




\subsection{COALBED METHANE RESOURCES}

\subsection{Summary}

The Powder River Coalbed Methane Basin Study estimates 61 Tcf of natural gas in-place, with 39 Tcf of this gas in-place being technically recoverable. The two reasons for the increased PRB coalbed methane resource in-place of 61 Tcf in this Basin Study are:

- $\quad$ Larger Coal Volume Data Base. The study includes extensive information on the deeper Fort Union coals prevalent in the basin; it compiles new data on the Wasatch coals on the western edge of the basin; and, it includes the shallower coals in the Montana portion of the PRB (although insufficient data was available for including the deeper Knoblock coal zone in the Montana portion of the PRB).

- $\quad$ Free Gas and Higher Gas Contents. The study identifies the presence of free gas in certain coal formations and establishes higher inherent gas content values for PRB coals than used by previous studies, both increasing the gas in-place over previous estimates.

The estimate of technically recoverable resources of $39 \mathrm{Tcf}$ is based on reservoir simulation of 1,428 individual wells assembled into 14 history-matched "time zero" well clusters. These simulations are used to construct 142 "type wells" representative of the distribution in well performance (gas and water production) for 12 distinct coal seams in 12 basin partitions.

\subsection{Coalbed Methane Resources}

\subsubsection{Gas In-Place}

The distribution of the 61 Tcf of gas in-place ranges widely by basin partition and by coal seam:

- Basin Partition \#5, in the center of the PRB, and where all of the major coal seams are present at favorable depths, holds over 25 Tcf of gas in-place.

- $\quad$ The Big George coal seam, that has extensive thickness in the southern and central portions of the PRB, holds over 14 Tcf of gas in-place, followed by the Canyon coal seam with nearly 9 Tcf of gas in-place.

Table 3-1 provides the partition and seam level tabulation for the coalbed methane gas in-place for the major coals in the Powder River Basin. (The Knoblock and other deeper coal seams are not included in these estimates.) 
Table 3-1. Gas In-Place for Major PRB Coal Seams (Bcf)

\begin{tabular}{|c|c|c|c|c|c|c|c|c|c|c|c|}
\hline & & \multicolumn{10}{|c|}{ Partitions } \\
\hline \multicolumn{2}{|c|}{$M$ ajor Seam s } & 18.2 & $3 \& 12$ & 4 & 5 & 6 & 7 & 8 & 9810 & 11 & TOT AL \\
\hline 1 & W as atch & & & & 181 & 460 & 292 & & & & 933 \\
\hline 2 & Roland & & & & 96 & 375 & 249 & & & & 720 \\
\hline 3 & $S m$ ith $1 S w$ a rtz & & & & 2,536 & & 160 & 471 & & & 3,167 \\
\hline 4 & Anderson ${ }^{*}$ & 41 & 159 & 399 & 1,180 & 373 & 323 & 748 & 102 & 1,233 & 4,558 \\
\hline 5 & Canyon* & 209 & 1,266 & 924 & 2,320 & 1,095 & 247 & 1,806 & 273 & 639 & 8,779 \\
\hline 6 & Wyodak* & 756 & & 891 & 250 & & & & & & 1,897 \\
\hline 7 & Big George & 544 & 6,618 & & 6,763 & 928 & & & & & 14,853 \\
\hline 8 & Cook & 154 & 210 & 447 & 3,056 & 693 & 401 & 2,281 & 381 & 214 & 7,837 \\
\hline 9 & Wall & & & 441 & 2,252 & 196 & 210 & 1,894 & & & 4,993 \\
\hline 10 & Pawnee & 473 & & 567 & 4,004 & 1,273 & 254 & 1,201 & 210 & & 7,982 \\
\hline 11 & Cache & & & 545 & 2,696 & & 679 & 493 & & & 4,413 \\
\hline \multirow[t]{2}{*}{12} & Oedekoven ${ }^{* * *}$ & & & & 180 & 757 & & 298 & & & 1,235 \\
\hline & TOTAL & 2,177 & 8,253 & 4,214 & 25,514 & 6,150 & 2,815 & 9,192 & 966 & 2,086 & 61,367 \\
\hline
\end{tabular}

Even with the extensive and detailed coal seam and township level mapping of the PRB coals, considerable uncertainty still remains in these resource estimates.

- $\quad$ First, only partial data exist on the volumes and location of the deep coals, because few wells have been drilled in the deeper portions of the basin. (New information would tend to increase the size of the in-place resource.)

- Second, localized areas of the basin may have encountered degassing of the coals. While this regional analysis indicates fully gas-charged coals, localized degassing of coals has been reported in other CBM basins. (Here, new information would tend to decrease the size of the in-place resource.)

- Third, coal seams with thickness of less than 20 feet are excluded from the resource estimate.

- Finally, considerable judgement is used in assigning a "name" to a particular coal seam, particularly where the Wyodak coal splits into sub-seams such as the Anderson and Canyon, which are major seams on their own. (Here, new information would shift the volume of resource among the seam, but would not appreciably affect the overall estimate.)

\subsubsection{Technically Recoverable Resources}

The distribution of the 39 Tcf of technically recoverable resources is shown on Table 3-2. Several insights emerge from the tabulation of data and reservoir simulation-based history matching of the well performance: 
- Recovery Efficiency With Depth. Recovery efficiency of the gas in-place does not decline as severely as conventionally assumed for the deeper coals. Higher coal reservoir pressure and more favorable gas content tends to partially counter-balance the reduction in coal permeability. Even so, the technical recovery efficiencies for certain of the deeper coals still only range from 50 to $60 \%$ of the gas in-place.

- Presence of Free Gas. The upper group of Fort Union coals, including the Anderson, Canyon and Wyodak, tend to have early gas production due to the presence of free gas within the coal cleat (fracture) system and in the coal matrix porosity. In addition to increasing the resource in place, the presence of free gas promotes improved relative permeability to gas and an earlier peak in gas production.

- Well Spacing. Where the coals have higher permeability and free gas, wells drilled on 40 to 80 acre spacings produce the bulk of their economically recoverable gas relatively quickly, in 6 to 7 years.

Table 3-2. Technically Recoverable Resources for Major PRB Coal Seams (Bcf)

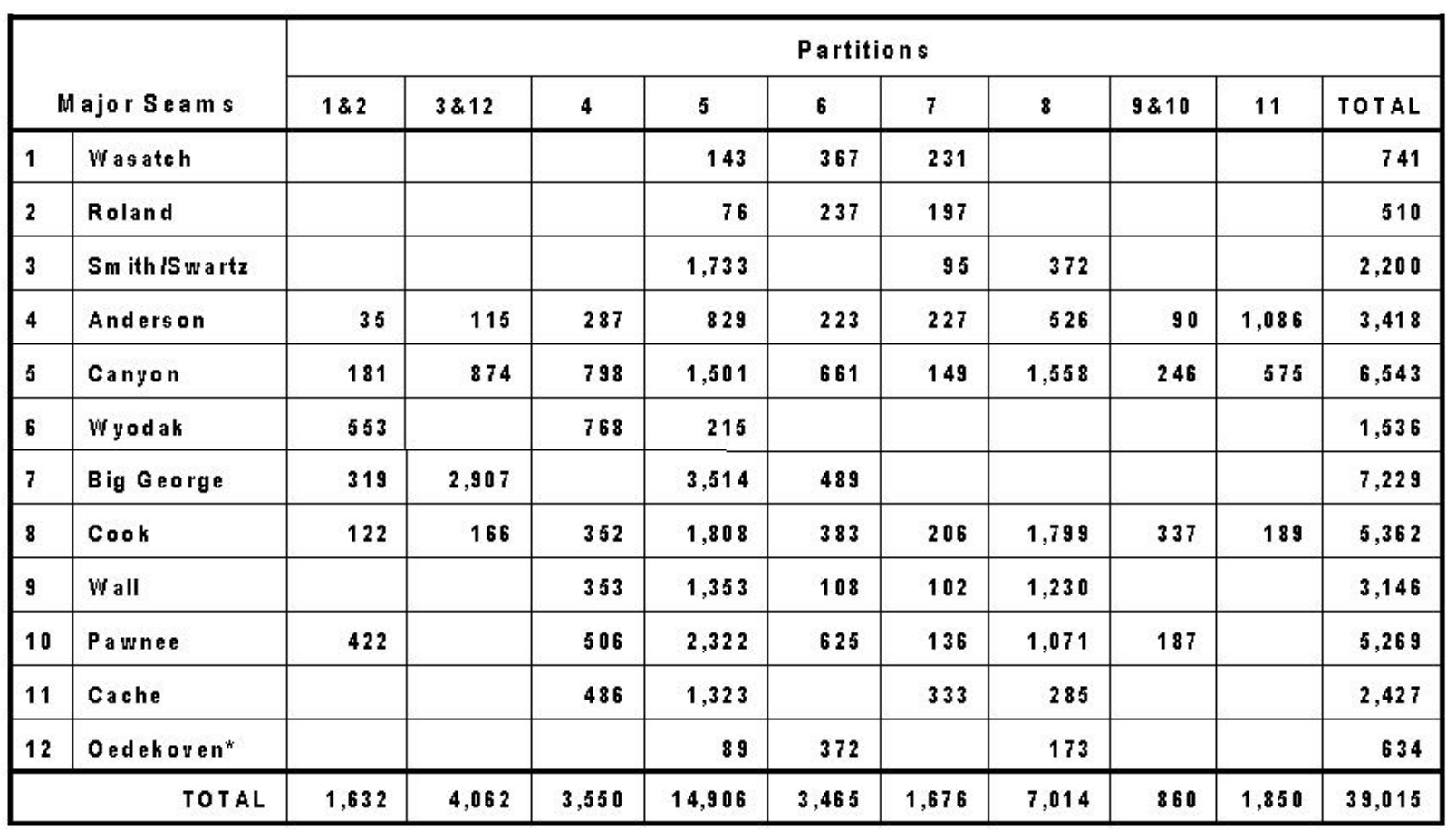

*Includes deep "wild cats."

\subsection{In-Place and Technically Recoverable PRB CBM Resources, by Basin Partition}

Tables 3-3 through 3-11 provide additional detail on in-place and technically recoverable PRB coalbed methane by basin partition. These tables display the areal extent (number of townships), depth, coal thicknesses, and gas content used to establish the gas in-place for each major coal seam. The tables also provide estimates of technically recoverable CBM resources by coal seam. 
Table 3-3. In-Place and Technically Recoverable CBM, Partitions \#1 and \#2

\begin{tabular}{|l||r|r|r|r||r|r|}
\hline Coal Seam & $\begin{array}{c}\text { No. Full } \\
\text { Townships }\end{array}$ & $\begin{array}{c}\text { Average } \\
\text { Depth } \\
\text { (ft) }^{*}\end{array}$ & $\begin{array}{c}\text { Average } \\
\text { Thickness } \\
\text { (ft) }\end{array}$ & $\begin{array}{c}\text { Average } \\
\text { Gas } \\
\text { Content } \\
\text { (cf/ton) }\end{array}$ & $\begin{array}{c}\text { Gas in } \\
\text { Place } \\
\text { (Bcf) }\end{array}$ & $\begin{array}{c}\text { Technically } \\
\text { Recoverable } \\
\text { (Bcf) }\end{array}$ \\
\hline Anderson & 1 & 450 & 25 & 39 & 40 & 30 \\
\hline Canyon & 2 & 575 & 48 & 51 & 210 & 180 \\
\hline Wyodak & 5 & 440 & 86 & 42 & 760 & 360 \\
\hline Big George & 2 & 863 & 90 & 86 & 550 & 120 \\
\hline Cook & 2 & 740 & 30 & 65 & 150 & 420 \\
\hline Pawnee & 5 & 1,336 & 22 & 108 & 470 & 1,630 \\
\hline Totals & & & & & 2,170 & \\
\hline
\end{tabular}

* Top of coal

Table 3-4. In-Place and Technically Recoverable CBM, Partitions \#3 and \#12

\begin{tabular}{|l||r|r|r|r||r|r|}
\hline \multicolumn{1}{|c||}{ Coal Seam } & $\begin{array}{c}\text { No. Full } \\
\text { Townships }\end{array}$ & $\begin{array}{c}\text { Average } \\
\text { Depth } \\
\text { (ft) }\end{array}$ & $\begin{array}{c}\text { Average } \\
\text { Thickness } \\
\text { (ft) }\end{array}$ & $\begin{array}{c}\text { Average } \\
\text { Gas Content } \\
\text { (cf/ton) }\end{array}$ & $\begin{array}{c}\text { Gas in } \\
\text { Place } \\
\text { (Bcf) }\end{array}$ & $\begin{array}{c}\text { Technically } \\
\text { Recoverable } \\
\text { (Bcf) }\end{array}$ \\
\hline Anderson & 1 & 800 & 55 & 70 & 160 & 110 \\
\hline Canyon & 9 & 970 & 43 & 107 & 6,620 & 870 \\
\hline Big George & 11 & 1,280 & 100 & 86 & 210 & 2,910 \\
\hline Cook & 2 & 1,030 & 30 & & & 170 \\
\hline Totals & & & & & & \\
\hline
\end{tabular}

*Top of coal 
Table 3-5. In-Place and Technically Recoverable CBM, Partition \#4

\begin{tabular}{|c|c|c|c|c|c|c|}
\hline Coal Seam & $\begin{array}{c}\text { No. Full } \\
\text { Townships }\end{array}$ & $\begin{array}{c}\text { Average } \\
\text { Depth } \\
(\mathrm{ft})^{*}\end{array}$ & $\begin{array}{c}\text { Average } \\
\text { Thickness } \\
\text { (ft) }\end{array}$ & $\begin{array}{c}\text { Average } \\
\text { Gas Content } \\
\text { (cf/ton) }\end{array}$ & $\begin{array}{c}\text { Gas In } \\
\text { Place } \\
\text { (Bcf) }\end{array}$ & $\begin{array}{c}\text { Technically } \\
\text { Recoverable } \\
\text { (Bcf) }\end{array}$ \\
\hline Anderson & 6 & 450 & 30 & 40 & 400 & 290 \\
\hline Canyon & 12 & 540 & 35 & 47 & 920 & 800 \\
\hline Wyodak & 6 & 601 & 73 & 54 & 890 & 770 \\
\hline Cook & 5 & 790 & 31 & 67 & 450 & 350 \\
\hline Wall & 5 & 1,020 & 27 & 84 & 440 & 350 \\
\hline Pawnee & 5 & 1,295 & 27 & 106 & 570 & 510 \\
\hline Cache & 5 & 1,550 & 23 & 121 & 540 & 480 \\
\hline Totals & 44 & & & & 4,210 & 3,550 \\
\hline
\end{tabular}

* To top of coal

Table 3-6. In-Place and Technically Recoverable CBM, Partition \#5

\begin{tabular}{|c|c|c|c|c|c|c|}
\hline Coal Seam & $\begin{array}{c}\text { No. Full } \\
\text { Townships }\end{array}$ & $\begin{array}{c}\text { Average } \\
\text { Depth } \\
(\mathrm{ft})^{*}\end{array}$ & $\begin{array}{c}\text { Average } \\
\text { Thickness } \\
\text { (ft) }\end{array}$ & $\begin{array}{c}\text { Average } \\
\text { Gas Content } \\
\text { (cf/ton) }\end{array}$ & $\begin{array}{c}\text { Gas In } \\
\text { Place } \\
\text { (Bcf) }\end{array}$ & $\begin{array}{c}\text { Technically } \\
\text { Recoverable } \\
\text { (Bcf) }\end{array}$ \\
\hline Felix & 4 & 530 & 24 & 46 & 180 & 140 \\
\hline Roland & 2 & 540 & 25 & 47 & 100 & 80 \\
\hline Smith & 18 & 820 & 39 & 70 & 2,310 & 1,560 \\
\hline Swartz & 2 & 740 & 43 & 63 & 220 & 180 \\
\hline Anderson & 9 & 1030 & 38 & 86 & 1,180 & 830 \\
\hline Canyon & 16 & 1060 & 39 & 88 & 2,320 & 1,500 \\
\hline Big George & 16 & 1280 & 97 & 107 & 6,760 & 3,510 \\
\hline Wyodak & 2 & 1000 & 73 & 85 & 250 & 210 \\
\hline Cook & 17 & 1320 & 40 & 109 & 3,060 & 1,810 \\
\hline Wall & 16 & 1500 & 32 & 120 & 2,250 & 1,350 \\
\hline Pawnee & 18 & 1710 & 41 & 137 & 4,000 & 2,320 \\
\hline Cache & 14 & 2020 & 32 & 159 & 2,700 & 1,320 \\
\hline Wildcat & 1 & 2190 & 45 & 101 & 180 & 90 \\
\hline Totals & & & & & 25,510 & 14,910 \\
\hline
\end{tabular}

* To top of coal 
Table 3-7. In-Place and Technically Recoverable CBM, Partition \#6

\begin{tabular}{|c|c|c|c|c|c|c|}
\hline Coal Seam & $\begin{array}{c}\text { No. Full } \\
\text { Townships }\end{array}$ & $\begin{array}{c}\text { Average } \\
\text { Depth } \\
\text { (ft)* }\end{array}$ & $\begin{array}{c}\text { Average } \\
\text { Thickness } \\
\text { (ft) }\end{array}$ & $\begin{array}{c}\text { Average } \\
\text { Gas Content } \\
\text { (cf/ton) }\end{array}$ & $\begin{array}{l}\text { Gas In } \\
\text { Place } \\
\text { (Bcf) }\end{array}$ & $\begin{array}{c}\text { Technically } \\
\text { Recoverable } \\
\text { (Bcf) }\end{array}$ \\
\hline Cameron & 1 & 700 & 20 & 60 & 50 & 40 \\
\hline Felix & 1 & 750 & 30 & 63 & 140 & 110 \\
\hline Murry & 1 & 800 & 50 & 69 & 80 & 60 \\
\hline Ucross & 3 & 790 & 23 & 66 & 190 & 150 \\
\hline Roland & 5 & 1,060 & 21 & 86 & 370 & 240 \\
\hline Anderson & 3 & 1,220 & 30 & 99 & 370 & 220 \\
\hline Canyon & 8 & 1,520 & 30 & 123 & 1,090 & 660 \\
\hline Big George & 2 & 1,670 & 85 & 136 & 930 & 490 \\
\hline Cook & 2 & 1,860 & 58 & 147 & 690 & 380 \\
\hline Wall & 1 & 1,630 & 40 & 130 & 200 & 110 \\
\hline Pawnee & 4 & 2,000 & 44 & 158 & 1,270 & 620 \\
\hline Wildcat & 4 & 2,640 & 25 & 191 & 760 & 370 \\
\hline Totals & & & & & 6,150 & 3,460 \\
\hline
\end{tabular}

* To top of coal

Table 3-8. In-Place and Technically Recoverable CBM, Partition \#7

\begin{tabular}{|c|c|c|c|c|c|c|}
\hline Coal Seam & $\begin{array}{c}\text { No. Full } \\
\text { Townships }\end{array}$ & $\begin{array}{c}\text { Average } \\
\text { Depth } \\
\text { (ft)* }\end{array}$ & $\begin{array}{c}\text { Average } \\
\text { Thickness } \\
\text { (ft) }\end{array}$ & $\begin{array}{c}\text { Average } \\
\text { Gas Content } \\
\text { (cf/ton) }\end{array}$ & $\begin{array}{c}\text { Gas In } \\
\text { Place } \\
\text { (Bcf) }\end{array}$ & $\begin{array}{c}\text { Technically } \\
\text { Recoverable } \\
\text { (Bcf) }\end{array}$ \\
\hline Wasatch & 6 & 540 & 25 & 47 & 290 & 230 \\
\hline Roland & 3 & 820 & 27 & 70 & 250 & 200 \\
\hline Smith & 2 & 1,180 & 20 & 96 & 160 & 90 \\
\hline Anderson & 5 & 910 & 21 & 75 & 320 & 230 \\
\hline Canyon & 2 & 1,500 & 25 & 120 & 250 & 150 \\
\hline Cook & 2 & 2,300 & 28 & 178 & 400 & 210 \\
\hline Wall & 1 & 2,500 & 30 & 186 & 210 & 100 \\
\hline Pawnee & 1 & 2,050 & 40 & 160 & 250 & 140 \\
\hline Cache & 3 & 2,623 & 30 & 190 & 680 & 330 \\
\hline Totals & & & & & 2,820 & 1,680 \\
\hline
\end{tabular}

* To top of coal 
Table 3-9. In-Place and Technically Recoverable CBM, Partition \#8

\begin{tabular}{|c|c|c|c|c|c|c|}
\hline Coal Seam & $\begin{array}{c}\text { No. Full } \\
\text { Townships }\end{array}$ & $\begin{array}{c}\text { Average } \\
\text { Depth } \\
\text { (ft)* }\end{array}$ & $\begin{array}{c}\text { Average } \\
\text { Thickness } \\
\text { (ft) }\end{array}$ & $\begin{array}{c}\text { Average } \\
\text { Gas Content } \\
\text { (cf/ton) }\end{array}$ & $\begin{array}{c}\text { Gas In } \\
\text { Place } \\
\text { (Bcf) }\end{array}$ & $\begin{array}{c}\text { Technically } \\
\text { Recoverable } \\
\text { (Bcf) }\end{array}$ \\
\hline Smith & 8 & 430 & 33 & 38 & 380 & 300 \\
\hline Swartz & 2 & 580 & 21 & 49 & 90 & 70 \\
\hline Anderson & 9 & 600 & 35 & 51 & 750 & 530 \\
\hline Canyon & 19 & 620 & 37 & 54 & 1,810 & 1,560 \\
\hline Cook & 22 & 730 & 39 & 62 & 2,280 & 1,800 \\
\hline Wall & 21 & 960 & 30 & 80 & 1,890 & 1,230 \\
\hline Pawnee & 11 & 1,060 & 33 & 87 & 1,200 & 1,070 \\
\hline Cache & 4 & 1,550 & 27 & 123 & 490 & 290 \\
\hline Oedekoven & 2 & 2,560 & 20 & 188 & 300 & 170 \\
\hline Totals & & & & & 9,190 & 7,020 \\
\hline
\end{tabular}

* To top of coal

Table 3-10. In-Place and Technically Recoverable CBM, Partitions \#9 and \#10

\begin{tabular}{|c|c|c|c|c|c|c|}
\hline Coal Seam & $\begin{array}{l}\text { No. Full } \\
\text { Townships }\end{array}$ & $\begin{array}{c}\text { Average } \\
\text { Depth } \\
(\mathrm{ft})^{*}\end{array}$ & $\begin{array}{c}\text { Average } \\
\text { Thickness } \\
\text { (ft) }\end{array}$ & $\begin{array}{c}\text { Average } \\
\text { Gas Content } \\
\text { (cf/ton) }\end{array}$ & $\begin{array}{l}\text { Gas in } \\
\text { Place } \\
\text { (Bcf) }\end{array}$ & $\begin{array}{c}\text { Technically } \\
\text { Recoverable } \\
\text { (Bcf) }\end{array}$ \\
\hline $\begin{array}{l}\text { Deitz } \\
\text { (Anderson) }\end{array}$ & 2 & 250 & 49 & 25 & 100 & 90 \\
\hline $\begin{array}{l}\text { Monarch } \\
\text { (Canyon) }\end{array}$ & 7 & 470 & 24 & 41 & 280 & 250 \\
\hline $\begin{array}{l}\text { Carney } \\
\text { (Cook) }\end{array}$ & 7 & 650 & 23 & 55 & 380 & 330 \\
\hline Pawnee & 3 & 1,080 & 20 & 88 & 210 & 190 \\
\hline Totals & & & & & 970 & 860 \\
\hline
\end{tabular}

* Top of coal 
Table 3-11. In-Place and Technically Recoverable CBM, Partitions \#11

\begin{tabular}{|c|c|c|c|c|c|c|}
\hline Coal Seam & $\begin{array}{l}\text { No. Full } \\
\text { Townships }\end{array}$ & $\begin{array}{c}\text { Average } \\
\text { Depth } \\
\text { (ft) }\end{array}$ & $\begin{array}{c}\text { Average } \\
\text { Thickness } \\
\text { (ft) }\end{array}$ & $\begin{array}{c}\text { Average } \\
\text { Gas Content } \\
\text { (cf/ton) }\end{array}$ & $\begin{array}{l}\text { Gas in } \\
\text { Place } \\
\text { (Bcf) }\end{array}$ & $\begin{array}{c}\text { Technically } \\
\text { Recoverable } \\
\text { (Bcf) }\end{array}$ \\
\hline $\begin{array}{l}\text { Deitz \#1 } \\
\text { (Anderson) }\end{array}$ & 5 & 910 & 24 & 75 & 510 & 450 \\
\hline Dietz \#2 & 5 & 680 & 24 & 58 & 330 & 290 \\
\hline Dietz \#3 & 6 & 1,030 & 22 & 84 & 390 & 340 \\
\hline $\begin{array}{l}\text { Monarch } \\
\text { (Canyon) }\end{array}$ & 8 & 1,070 & 24 & 88 & 640 & 570 \\
\hline $\begin{array}{l}\text { Carney } \\
\text { (Cook) }\end{array}$ & 3 & 1,030 & 23 & 84 & 220 & 190 \\
\hline Totals & & & & & 2,090 & 1,850 \\
\hline
\end{tabular}

*Top of coal

\subsection{Estimating Gas and Water Production}

The gas and water production estimates for the study were developed using the following six steps:

1. Geologic Model. The geologic model (discussed above) provided the key reservoir properties of coal seam depth, thickness, gas content and reservoir pressure.

2. Well Performance. The gas and water production data base (starting with over 8,000 CBM wells in the PRB) was organized by coal seam and by partition and then normalized by time (using "time zero" plots) to provide a foundation of actual CBM well performance. For example, Figure 3-1 provides the "time-zero" plot for "on average" wells completed in the Wyodak coal seam in a 2-township area of Partition \#4. (See Section 6.4 for further discussion.)

3. History Matching. History matching of gas and water production (from 1,428 PRB CBM wells, organized into 14 distinct coal seam and basin partition sets (shown on Table 3-12) was used to establish:

- $\quad$ Permeability (matrix, fracture)

- Coal porosity (matrix, fracture)

- $\quad$ Gas and water saturation

- Confirmation of reservoir pressure and gas content

For example, Figure 3-2 provides the gas and water production history match for the "average" well completed in the Wyodak coal seam in the 2-township area of Partition \#4, shown in Figure 3-1. (See Section 6.4 for further discussion.). Table 3-13 summarizes the reservoir properties and expected gas and water recoveries for the 14 sets of history-matched PRB coalbed methane wells. 


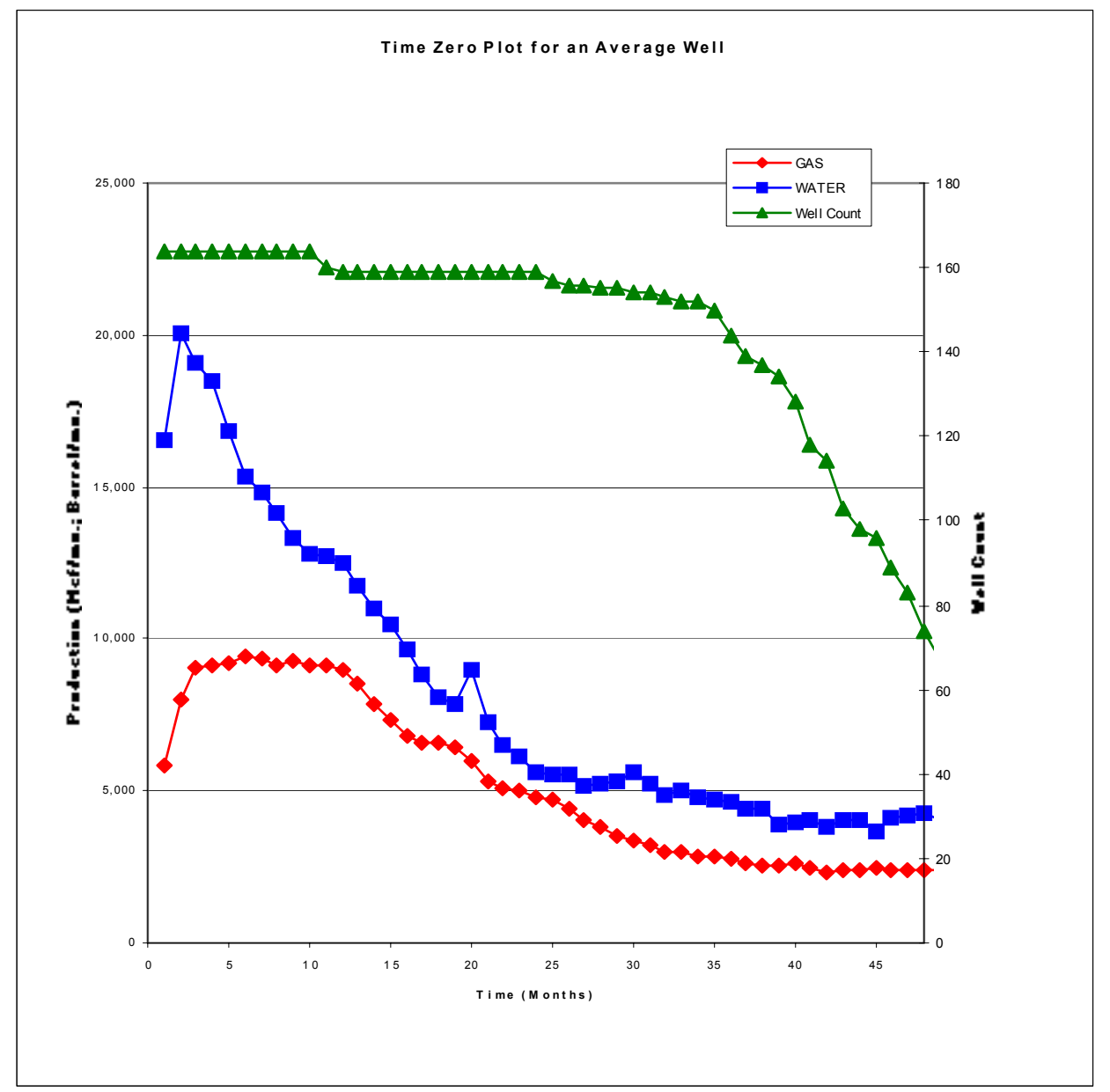

Figure 3-1. Wyodak Coal Seam Time Zero Plot

Table 3-12. Number and Nature of CBM Wells for History Matching

\begin{tabular}{|l|c|c|c|c|c|}
\hline \multirow{2}{*}{ Coal Seam } & \multicolumn{5}{c|}{ Partitions $^{4}$} \\
\cline { 2 - 6 } & 3 & 4 & 5 & 8 & 11 \\
\hline Smith & & & $10^{2}$ & & \\
\hline Anderson & & $89^{1}$ & & $261^{1}$ & $191^{1}$ \\
\hline Canyon & & $172^{1}$ & & & $147^{1}$ \\
\hline Wyodak & & $159^{1}$ & & & \\
\hline Big George & $38^{1}$ & & $17^{3}$ & & \\
\hline Cook & & & & $134^{1}$ & $65^{1}$ \\
\hline Wall & & 191 & & $107^{2}$ & \\
\hline Pawnee & & & & $19^{2}$ & \\
\hline
\end{tabular}

1 Intensely drilled township area

3 Time zero well in partition.

3 All Big George wells in Sec. 16, 48N 77W.

4 Includes partitions with significant numbers of CBM wells, with sufficient production data for history matching. 


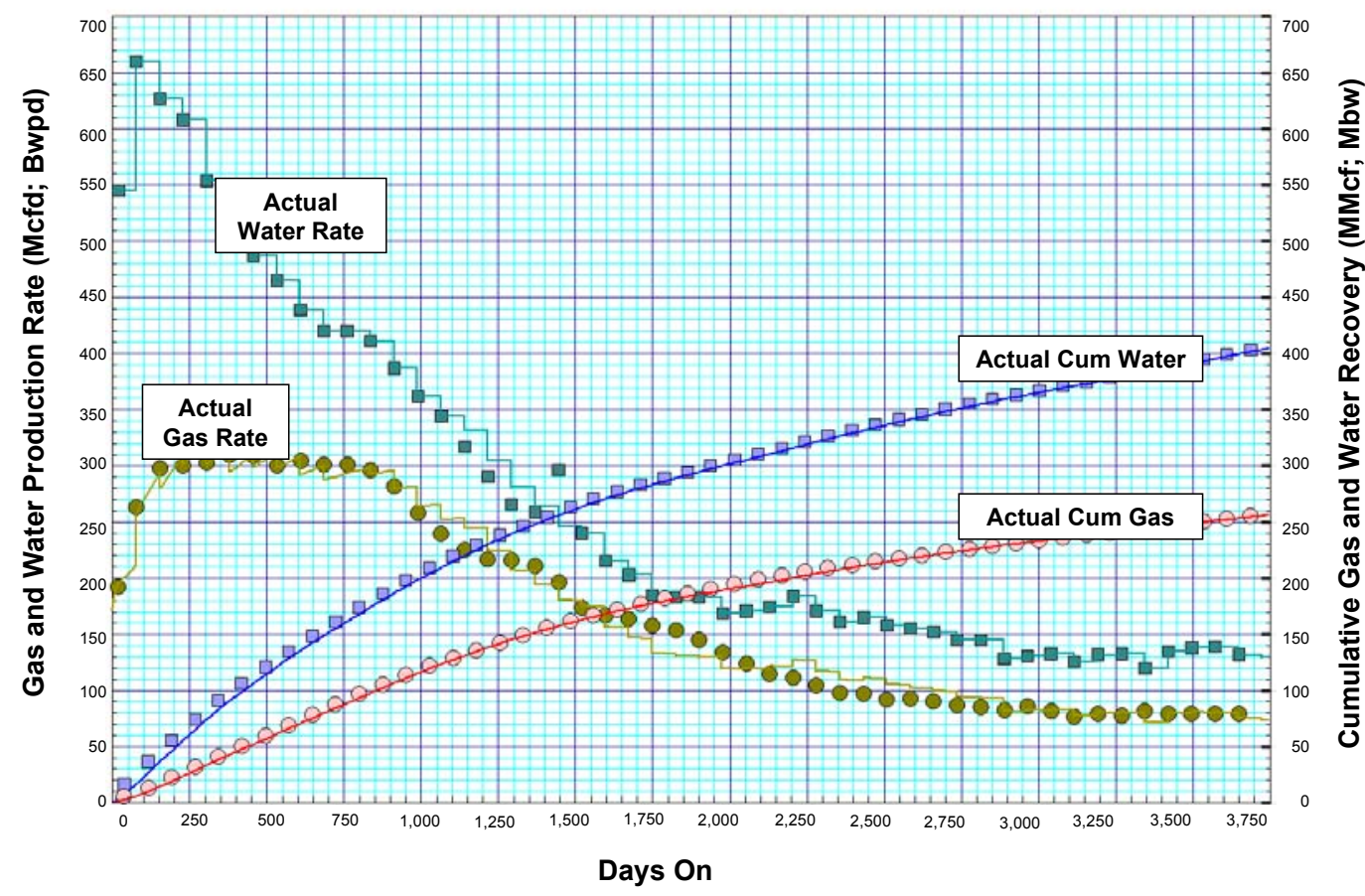

Figure 3-2. Wyodak Type Well History Match

Table 3-13. Summary Results for PRB Coalbed Methane History Matching

\begin{tabular}{|c|c|c|c|c|c|c|c|c|c|c|c|c|c|c|c|c|c|}
\hline & B & C & $\mathrm{D}$ & $E$ & $\mathrm{~F}$ & G & $\mathrm{H}$ & I & $\mathrm{J}$ & $\mathrm{K}$ & L & $M$ & $\mathrm{~N}$ & 0 & $\mathrm{P}$ & Q & $\mathrm{R}$ \\
\hline 2 & Seam & Part & Area & $\underline{\underline{\# \text { of }}}$ & $\frac{\text { Depth }}{(\text { Top) } \mathrm{ft}}$ & $\frac{\text { Thickness }}{\text { (ft) }}$ & $\frac{\text { Spacing }}{(\mathrm{A} / \mathrm{W})}$ & $\begin{array}{l}\text { Pressure } \\
\text { (top) psi }\end{array}$ & $\frac{\frac{\text { Pressure }}{\text { Gradient, }}}{\text { psi/ft }}$ & $\frac{\text { Comparison }}{\frac{\text { to Regional }}{\text { Prs Grad }}}$ & $\frac{\text { Gas }}{\text { Content }}$ & $\begin{array}{l}\frac{\text { Gas }}{\text { Content }} \\
\text { (cf/ton) }\end{array}$ & $\frac{\text { Porosity }}{\underline{f}}$ & $\frac{\text { Porosity }}{\underline{m}}$ & $\underline{S w-f}$ & $\underline{S_{w}-m}$ & $\frac{\operatorname{Perm}(\mathrm{md})}{\underline{f}}$ \\
\hline 3 & Big G & & T43-44N 74W & 38 & 1,000 & 67.5 & 80 & 335 & 0.320 & Same & 3.58 & 86 & 0.002 & 0.040 & 1.00 & 1.00 & 35.0 \\
\hline \multicolumn{18}{|c|}{4} \\
\hline 5 & Anderson & & T51N 73W & 89 & 500 & 20.0 & 80 & 150 & 0.270 & Same & 1.79 & 43 & 0.002 & 0.015 & 0.92 & 0.90 & 225.0 \\
\hline$\frac{5}{6}$ & Wyodak & & T47-48 R72 & 159 & 541 & 78.0 & 40 & 163 & 0.274 & Same & 2.73 & 65 & 0.010 & 0.060 & 0.95 & 0.90 & 500.0 \\
\hline 7 & Canyon & & T52-51 R73 & 172 & 625 & 37.5 & 80 & 186 & 0.273 & Same & 2.19 & 52 & 0.004 & 0.030 & 0.93 & 0.93 & 200.0 \\
\hline 8 & Wall & & T52N 73W & 19 & 800 & 25.0 & 80 & 255 & 0.300 & Same & 2.82 & 67 & 0.010 & 0.100 & 1.00 & 1.00 & 100.0 \\
\hline \multicolumn{18}{|l|}{9} \\
\hline$\frac{5}{10}$ & Big G & & 1 WELL & 1 & 1,260 & 150.0 & 80 & 451 & 0.346 & Same & 4.33 & 104 & 0.010 & 0.100 & 1.00 & 1.00 & 250.0 \\
\hline 11 & Smith & & AVG & 10 & 640 & 30.0 & 80 & 197 & 0.284 & Same & 2.29 & 55 & 0.001 & 0.011 & 1.00 & 1.00 & 45.0 \\
\hline \multicolumn{18}{|c|}{12} \\
\hline 13 & Anderson & & T54 R76-77 & 261 & 650 & 52.5 & 80 & 200 & 0.285 & Same & 1.80 & 43 & 0.002 & 0.015 & 1.00 & 0.78 & 175.0 \\
\hline 14 & Wall & & AVG & 107 & 963 & 30.0 & 80 & 300 & 0.296 & Lower & 3.22 & 77 & 0.010 & 0.095 & 1.00 & 1.00 & 42.0 \\
\hline$\frac{14}{15}$ & \begin{tabular}{|l|} 
Pawnee \\
Pawn
\end{tabular} & & AVG & 19 & 1,055 & 33.0 & 80 & 358 & 0.325 & Same & $\frac{3.22}{3.70}$ & 89 & 0.005 & 0.050 & 1.00 & 1.00 & 125.0 \\
\hline 16 & Cook & & T55N 75-76W & 134 & 752 & 55.0 & 80 & 237 & 0.295 & Same & 2.71 & 65 & 0.001 & 0.024 & 1.00 & 0.99 & 50.0 \\
\hline \multicolumn{18}{|c|}{17} \\
\hline 18 & Anderson-Dietz & & T57N R83-84W & 191 & 650.0 & 22.5 & 80 & 200 & 0.285 & Same & 2.30 & 55 & 0.005 & 0.025 & 0.98 & 0.98 & 450.0 \\
\hline 19 & Canyon-Monarch & & \begin{tabular}{l|l} 
T57N R83-84W \\
\end{tabular} & 147 & 930.0 & 20.0 & 80 & 306 & 0.313 & Same & 3.25 & 78 & 0.005 & 0.095 & 0.98 & $\begin{array}{l}0.98 \\
0.98\end{array}$ & $\frac{450.0}{275.0}$ \\
\hline 20 & \begin{tabular}{|l} 
Cook-Carney \\
\end{tabular} & & T57N R83-84W & $\frac{141}{65}$ & $1,050.0$ & 30.0 & 80 & 356 & 0.325 & Same & 3.68 & 88 & 0.010 & 0.080 & 0.99 & 0.99 & 150.0 \\
\hline \multicolumn{18}{|l|}{21} \\
\hline \multicolumn{18}{|c|}{$\frac{22}{23}$} \\
\hline$\frac{25}{24}$ & Anderson & & T51N 73W & 89 & 500 & 20.0 & 80 & 150 & 0.270 & Same & 1.79 & 43 & 0.002 & 0.015 & 0.92 & 0.90 & 225.0 \\
\hline$\frac{24}{25}$ & Anderson & & T54 R76-77 & 2691 & 650 & 20.0 & 80 & 200 & 0.285 & Same & $\frac{1.19}{1.80}$ & $\frac{45}{43}$ & $\begin{array}{l}0.002 \\
0.002\end{array}$ & 0.015 & \begin{tabular}{ll|}
1.02 \\
1.00
\end{tabular} & $\begin{array}{ll}.90 \\
0.78\end{array}$ & $\frac{2<0.0}{175.0}$ \\
\hline$\frac{26}{26}$ & Anderson-Dietz & & 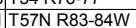 & 191 & 650 & 22.5 & 80 & 200 & 0.285 & Same & 2.30 & 55 & 0.005 & 0.025 & 0.98 & 0.98 & 450.0 \\
\hline \multicolumn{18}{|l|}{\begin{tabular}{|l|}
27 \\
27
\end{tabular}} \\
\hline 28 & Big G & & T43-44N 74W & 38 & 1,000 & 67.5 & 80 & 335 & 0.320 & Same & 3.58 & 86 & 0.002 & 0.040 & 1.00 & 1.00 & 35.0 \\
\hline 29 & Big G & & 1 WELL & & 1,260 & 150.0 & 80 & 451 & 0.346 & Same & 4.33 & 104 & 0.010 & 0.100 & 1.00 & 1.00 & 250.0 \\
\hline \\
\hline 31 & Canyon & & T52-51 R73 & 172 & 625 & 37.5 & 80 & 186 & 0.273 & Same & 2.19 & 52 & 0.004 & 0.030 & 0.93 & 0.93 & 200.0 \\
\hline 32 & Canyon-Monarch & & T57N R83-84W & 147 & 930 & 20.0 & 80 & 306 & 0.313 & Same & 3.25 & 78 & 0.005 & 0.095 & 0.98 & 0.98 & 275.0 \\
\hline \multicolumn{18}{|l|}{33} \\
\hline 34 & Cook & & T55N 75-76W & 134 & 752 & 55.0 & 80 & 237 & 0.295 & Same & 2.71 & 65 & 0.001 & 0.024 & 1.00 & 0.99 & 50.0 \\
\hline 35 & Cook-Carney & & T57N R83-84W & 65 & 1,050 & 30.0 & 80 & 356 & 0.325 & Same & 3.68 & 88 & 0.010 & 0.080 & 0.99 & 0.99 & 150.0 \\
\hline \multicolumn{18}{|c|}{36} \\
\hline 37 & Pawnee & & AVG & 19 & 1,055 & 33.0 & 80 & 358 & 0.325 & Same & 3.70 & 89 & 0.005 & 0.050 & 1.00 & 1.00 & 125.0 \\
\hline \multicolumn{18}{|l|}{38} \\
\hline 39 & Smith & & AVG & 10 & 640 & 30.0 & 80 & 197 & 0.284 & Same & 2.29 & 55 & 0.001 & 0.011 & 1.00 & 1.00 & 45.0 \\
\hline \multicolumn{18}{|c|}{\begin{tabular}{l|l}
40 \\
40
\end{tabular}} \\
\hline 41 & Wall & & T52N 73W & 19 & 800 & 25.0 & 80 & 255 & 0.300 & Same & 2.82 & 67 & 0.010 & 0.100 & 1.00 & 1.00 & 100.0 \\
\hline 42 & Wall & & AVG & 107 & 963 & 30.0 & 80 & 300 & 0.296 & Lower & 3.22 & 77 & 0.010 & 0.095 & 1.00 & 1.00 & 42.0 \\
\hline \multicolumn{16}{|l|}{43} & & \\
\hline 44 & Wyodak & & T47-48 R72 & 159 & 541 & 78.0 & 40 & 163 & 0.274 & Same & 2.73 & 65 & 0.010 & 0.060 & 0.95 & 0.90 & 500.0 \\
\hline
\end{tabular}


4. Reservoir Simulation. Advanced Resources' COMET3 reservoir simulator, a triple porosity and triple permeability finite difference model specifically developed for coalbed methane production and reserve assessments, was used for history matching and establishing 14 "type wells" reflecting the geologic and reservoir diversity encountered in PRB coals.

5. Production Forecast. The history-matched "type wells" were extended in time (using COMET3) to provide 10-year gas and water rates and estimates of ultimate recovery. For example, Figure 3-3 provides the 10-year reservoir simulation-based forecast for gas and water production for the Wyodak type well in Partition \#4, as presented previously in Figures 3-1 and 3-2.

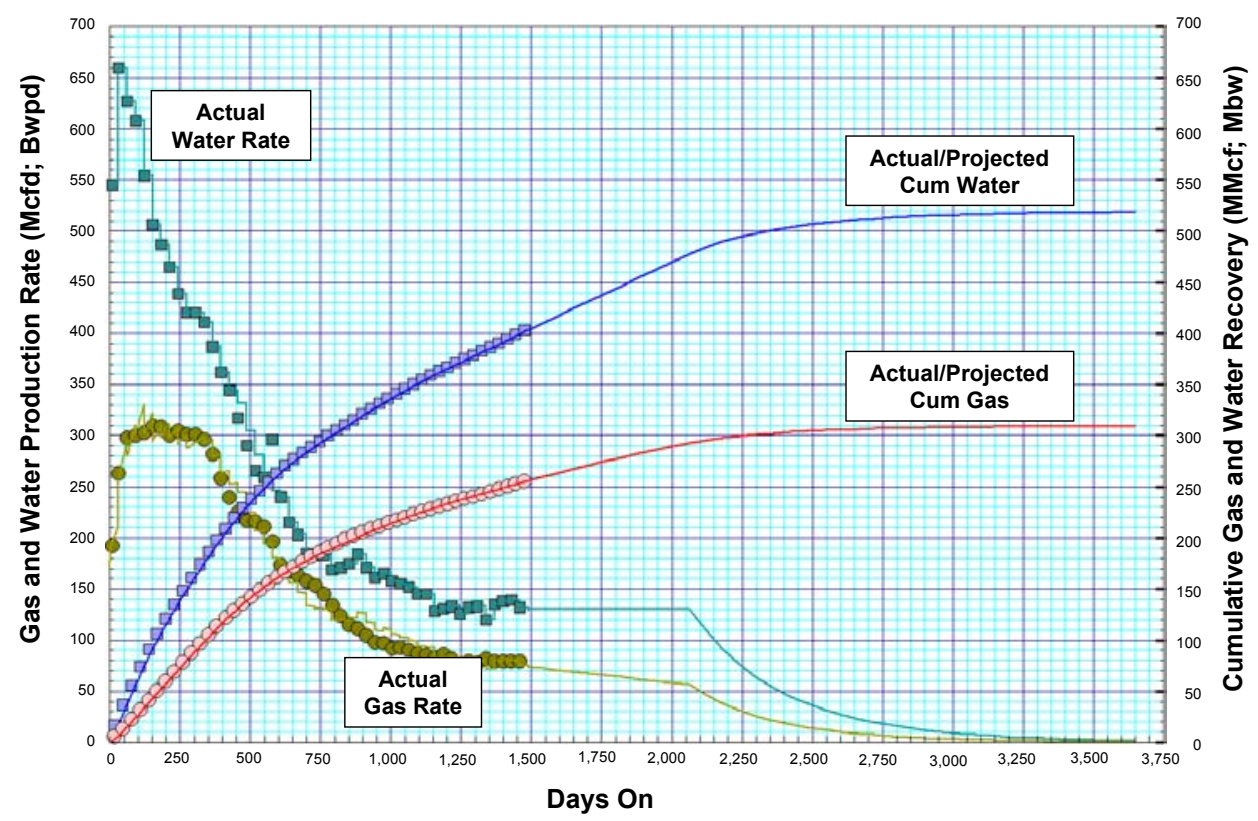

Figure 3-3. 10-Year Simulation of Gas and Water Production for Wyodak Type Well

6. Type Wells. The 14 PRB "type wells" were scaled using actual depth, thickness and gas content to develop 142 individual "type wells" to reflect average, high and low performance for each major coal seam in each basin partition, shown on Table 3-14. For example, the history-matched set of 89 Anderson wells in T51N T3W of Partition \#4 (shown previously on Table 3-13), with a coal thickness of 20 feet, were scaled to represent the average 30 foot coal thickness "type well" for the Anderson coal seam in Partition \#4 (as shown in Table 3-5). The expected average, high and low well performance was based primarily on the variability in coal thickness in the partition. The average well represents the average coal thickness (and other reservoir properties) value and the low and high wells represent the lowest and highest $25 \%$ of the coal thickness in the townships of the partition. 
Table 3-14. Number of CBM Type Wells for Basin Assessment

\begin{tabular}{|c|c|c|c|c|c|c|c|c|c|c|c|}
\hline \multirow{2}{*}{\multicolumn{2}{|c|}{ Major Seams }} & \multicolumn{10}{|c|}{ Partitions } \\
\hline & & \multirow[t]{2}{*}{$1 \& 2$} & \multirow[t]{2}{*}{$3 \& 12$} & \multirow[t]{2}{*}{4} & & \multirow{2}{*}{\begin{tabular}{|l|}
6 \\
4
\end{tabular}} & \multirow{2}{*}{\begin{tabular}{|l|}
7 \\
3 \\
\end{tabular}} & \multirow[t]{2}{*}{8} & \multirow[t]{2}{*}{$9 \& 10$} & \multirow[t]{2}{*}{11} & \multirow{2}{*}{$\begin{array}{r}\text { TOTAL } \\
8\end{array}$} \\
\hline 1 & Wasatch & & & & & & & & & & \\
\hline 2 & Roland & & & & 1 & 1 & 3 & & & & 5 \\
\hline 3 & Smith/Swartz & & & & 4 & & 1 & 4 & & & 9 \\
\hline 4 & Anderson & 1 & 1 & 3 & 3 & 1 & 3 & 3 & 1 & 9 & 25 \\
\hline 5 & Canyon & 2 & 3 & 3 & 3 & 3 & 1 & 3 & 3 & 3 & 24 \\
\hline 6 & Wyodak & 3 & & 3 & 1 & & & & & & 7 \\
\hline 7 & Big George & 1 & 3 & & 3 & 1 & & & & & 8 \\
\hline 8 & Cook & 1 & 1 & 3 & 3 & 1 & 1 & 3 & 3 & 3 & 19 \\
\hline 9 & Wall & & & 3 & 3 & 1 & 1 & 3 & & & 11 \\
\hline 10 & Pawnee & 1 & & 3 & 3 & 3 & 1 & 3 & 1 & & 15 \\
\hline 11 & Cache & & & 3 & 3 & & 1 & 3 & & & 10 \\
\hline 12 & Oedekoven* & & & & & 1 & & & & & 1 \\
\hline & TOTAL & 9 & 8 & 21 & 28 & 16 & 14 & 23 & 8 & 15 & 142 \\
\hline
\end{tabular}

* Includes deep "wildcats." 


\subsection{COSTS OF PRB CBM DEVELOPMENT}

This section presents the cost model used for assessing the economics of Powder River Basin (PRB) coalbed methane (CBM) development. The section contains:

- A summary presentation of the basic capital, operating and maintenance, gas transportation and compression, and water disposal costs,

- A discussion of other financial considerations such as royalties, production taxes, and basin differentials,

- More detailed discussions of CBM capital costs,

- $\quad$ More detailed discussion of CBM O\&M costs, and

- A discussion of water disposal capital and O\&M costs for four water management alternatives - surface disposal, infiltration impoundment, shallow re-injection and active treatment using reverse osmosis.

\subsection{Basic Cost Model}

\subsubsection{Introduction}

This section provides the basic capital and operating cost model for Powder River Basin coalbed methane development. The model attempts to reflect a series of "typical" CBM wells in the basin, with cost variability determined by well depth, geographic location and volume of gas and water production. In reality, the variability in costs is much greater than can be defined by these "typical" CBM wells and the three factors (depth, location, and gas and water production) that are used to capture a portion of this variability. As such, the cost and well performance information are intended for use on a regional rather than a site or prospect-specific basis.

The authors are deeply indebted to the many sources of cost information made available for this study. These include contributions of cost data from the producers and service companies in the basin, detailed cost data from Advanced Resources' past studies of coalbed methane in the Powder River Basin and other coal basins, and the cost surveys and comments by the Producers Association of Wyoming. We welcome suggestions and data that would improve the quality of the information and the cost model.

\subsubsection{Capital Costs for PRB CBM Well}

The basic capital costs for a PRB CBM well include outlays for land, permits, drilling and completion, and infrastructure (capital costs for water disposal are presented later). These costs vary considerably by well depth and location. For example purposes, we will use a Powder River Basin coalbed methane well at 600 feet of depth, spaced on 80 acres, with 2 wells per pad. Capital costs are per well, assuming a 16-well, 8-pad development unit. Gas treating and compression is assumed, provided by a third party contract. Additional detail on each of the cost items and how costs vary with depth are provided in subsequent sections of this report. 
The basic capital costs for the above described example PRB CBM well are estimated at $\$ 88,000$, as shown below.

Table 4-1. Capital Costs for PRB CBM Well

\begin{tabular}{|c|c|}
\hline Cost Item & Capital Costs \\
\hline Land Costs and Permits & $\$ 13,000$ \\
\hline Well Drilling and Completion (@600 feet) & 48,180 \\
\hline Water Gathering* & 10,210 \\
\hline Electric Power, inc. cable ${ }^{* *}$ & 8,450 \\
\hline Gas Gathering*** & 7,820 \\
\hline Miscellaneous & 340 \\
\hline Total & $\$ 88,000$ \\
\hline
\end{tabular}

* Allocated based on small diameter water gathering piping of 2,000 feet per well (including common trenching and survey for water, gas, and electrical cable), central water transportation (2 lines) of 10,000 feet, right of way for 42,000 feet, two surface pumps and contingency insurance and other costs of $10 \%$.

${ }^{* *}$ Allocated based on central 3-phase power installation costs of $\$ 75,000$ per unit, electrical cable of 2,000 feet per well, and contingency, insurance and other costs of $10 \%$.

${ }^{* * *}$ Allocated based on small diameter gas gathering piping of 2,000 feet per well, central gas transportation (2 lines) of 10,000 feet, and contingency, insurance and other costs of $10 \%$.

\subsubsection{O\&M Costs for PRB CBM Well}

The basic lease and well operating and maintenance (O\&M) costs for a Powder River coalbed methane well varies by year of production, with higher costs during the initial years because of more frequent well enhancements and pump replacements. Additional detail on these costs is provided in subsequent sections of this report.

For illustrative example purposes, assuming CBM recovery of $0.3 \mathrm{Bcf}$ (gross) per well, the O\&M costs are $\$ 0.215$ per Mcf and G\&A costs are $\$ 0.043$ per Mcf, for total O\&M/G\&A costs of $\$ 0.258$ per Mcf. Additional O\&M costs are incurred for water management and disposal, as discussed later. 
Table 4-2. O\&M Costs for PRB CBM Well

\begin{tabular}{|l|r|r|r|r|}
\cline { 2 - 5 } \multicolumn{1}{c|}{} & \multicolumn{3}{c|}{ O\&M Costs/Well } \\
\cline { 2 - 5 } \multicolumn{1}{c|}{} & \multicolumn{2}{c|}{ Basic O\&M* } & \multicolumn{2}{c|}{ O\&M Inc.G\&A } \\
\cline { 2 - 5 } & Annual & Monthly & Annual & Monthly \\
\hline Year 1 & $\$ 16,700$ & $\$ 1,390$ & $\$ 20,040$ & $\$ 1,670$ \\
\hline Years 2 - & $\$ 7,500$ & $\$ 625$ & $\$ 9,000$ & $\$ 750$ \\
\hline Years 5 - 10 & $\$ 4,200$ & $\$ 350$ & $\$ 5,040$ & $\$ 420$ \\
\hline TOTAL (Years 1 - 10) & $\$ 64,400$ & $\$ 644$ & $\$ 77,280$ & $\$ 773$ \\
\hline
\end{tabular}

${ }^{*} A$ G\&A charge of $20 \%$ for engineering, accounting, legal and other indirect costs is added to basic well costs.

\subsubsection{Gas Transportation, Compression, and Fuel Use}

The costs of gas treatment, compression and transportation are subtracted from the PRB netback price to establish a PRB CBM wellhead price. The costs will vary, depending on the gathering system charges for transporting natural gas from the compressor to the Colorado Interstate Gas (CIG), or another hub, and on the nature and extent of contracted third-party compression. These costs depend on the location of the CBM development in the PRB, as follows:

- A charge of $\$ 0.43$ per Mcf is used for third-party compression and dehydration (assuming no lease compression), and for transportation for the central and southern portions of the PRB (Partitions \#1, 2, 3, 4, and 5).

- A charge of $\$ 0.57$ per Mcf is used for third-party compression and dehydration (assuming no lease compression), and for transportation for the northeast and southwest portions of the PRB (Partitions \#6, 8, and 9).

- A charge of $\$ 0.77$ per Mcf is used for third-party compression and dehydration (assuming no lease compression), and for transportation for the northwest and western portions of the PRB (Partitions \#7, 10, 11 and 12).

A fuel adjustment ("shrinkage") for operating gas powered compressor stations, estimated at 4 to $6 \%$ of gross production, is subtracted from the sales volume. A second fuel adjustment ("shrinkage"), involving the BTU adjustment for CBM, generally 2 to $8 \%$ (to account for 920 to 980 Btu content gas), is also subtracted from the sales volume.

\subsubsection{Water Disposal Alternatives}

Alternatives. A series of alternatives are being used or considered for CBM water disposal in the Powder River Basin, including:

- $\quad$ Untreated or passively treated water with surface discharge. 
- Infiltration impoundment with enhanced evaporation and/or land application.

- Shallow re-injection of the produced water.

- $\quad$ Actively treated water with infiltration, evaporation, land application, and/or surface discharge, and disposition of the residual concentrate by trucking or deep re-injection.

Deep re-injection of the untreated, relatively high-quality CBM produced water would constitute a loss of a valuable resource and thus has not been included among the water disposal alternatives in this study.

Capital Costs. The capital costs for the alternative CBM water disposal options add from $\$ 1,400$ to $\$ 35,200$ per well, depending on the water management alternative selected, as shown for the example well below.

Table 4-3. Capital Costs for Alternate Methods of Water Disposal

\begin{tabular}{|l|r|r|}
\cline { 3 - 3 } \multicolumn{2}{c}{} & \multicolumn{2}{c|}{ Water Disposal Costs } \\
\cline { 2 - 3 } & Capital Costs/Well & O\&M Costs/Bbl.* \\
\hline Water Disposal & $\$ 1,400$ & $\$ 0.02$ \\
\hline Surface Discharge & $\$ 10,300$ & $\$ 0.06$ \\
\hline Infiltration Impoundment & $\$ 15,150$ & $\$ 0.06$ \\
\hline Shallow Re-Injection & & $\$ 0.24$ \\
\hline $\begin{array}{l}\text { Active Treatment w/Disposal of } \\
\text { Residual Concentrate }\end{array}$ & $\$ 19,600$ & $\$ 0.14$ \\
\hline - Trucking & $\$ 35,200$ & \\
\hline - Deep Re-Injection & & \\
\hline
\end{tabular}

O\&M Costs. The operating costs of alternative CBM water disposal options will add from $\$ 0.02$ to $\$ 0.25$ per barrel of produced water to basic well and lease O\&M costs, depending on the water management alternative selected.

\subsubsection{Other Considerations}

Royalties. Royalty payments for PRB CBM production depend on mineral ownership, as set forth below:

- $\quad$ Royalties on federal lands are $12.5 \%$.

- $\quad$ Royalties on state lands are $16.7 \%$.

- $\quad$ Royalties on private lands range from $15 \%$ to $20 \%$.

State Severance and Ad Valorem Taxes. State and county tax payments for PRB CBM production are state specific, as set forth below:

- Wyoming severance and ad valorem taxes are $12 \%$. 
- $\quad$ Montana severance taxes are $9.3 \%$.

\subsubsection{Basin Differentials}

Because of higher transportation costs and other market conditions, the gas price at the CIG (or another Wyoming/Rocky Mountain) hub is discounted from a marker price, as set by the Henry Hub or NYMEX (commonly called the "basin differential"). As of mid-June 2002, with the Henry Hub gas price at \$3.11 per MMBtu, the Wyoming Pool and the Opal hub are both at \$1.33 per MMBtu, for a basin differential of $\$ 1.78$ per MMBtu.

The economic model assumes that the long-term basin differential between Henry Hub and Rocky Mountain hubs reverts back to a historically-based value of $\$ 0.80$ per MMBtu, as published by Petrie Parkman \& Co. (October 2000). Sensitivity cases have been run to examine the effects of higher basin differentials.

\subsection{Discussion of CBM Development Capital Costs}

\subsubsection{Land Costs and Permits}

Regular land and permit costs for CBM development in the Powder River Basin include the following:

- $\quad$ Mineral lease purchase and maintenance.

- WOGCC hearing, division orders, and permits.

- $\quad$ DEQ, State Engineer Office and BLM permits.

The costs for water disposal permits are included later.

The costs for mineral leases is $\$ 200$ per acre; the costs for regular permitting and studies is $\$ 5,000$ for an 80 -acre well pad. For a federal lease, additional costs are required for NEPA and other permitting studies, estimated to cost an additional \$10,000 for an 80-acre well pad. Assuming approximately one-half of the leases are federal, this would add $\$ 5,000$ of costs for an average permit.

The total land and permit costs for an 80 -acre well pad are estimated at $\$ 26,000$. With two wells per pad, the cost per CBM well is $\$ 13,000$.

\subsubsection{Well Drilling and Completion}

Well drilling and completion costs are governed primarily by well depth, assuming single zone coal seam completions. The intangible (expensed) and tangible (capitalized) drilling and completion costs for two representative PRB CBM wells, one at 500 feet and one at 850 feet, are provided below: 
Table 4-4. Sample Tangible and Intangible Costs for Two PRB CBM Wells

\begin{tabular}{|c|c|c|}
\hline & \multicolumn{2}{|c|}{ Coal Seam Depth } \\
\hline & 500 feet & 850 feet \\
\hline Well Drilling Costs & $\$ 28,200$ & $\$ 36,500$ \\
\hline Intangible & 24,400 & 30,500 \\
\hline Tangible & 3,800 & 6,000 \\
\hline Well Completion Costs & $\$ 12,800$ & $\$ 14,300$ \\
\hline Intangible & 4,700 & 4,700 \\
\hline Tangible & 8,100 & 9,600 \\
\hline TOTAL* & $\$ 41,000$ & $\$ 50,800$ \\
\hline
\end{tabular}

A significant number of the cost items, such as site preparation, rentals, wellhead, and gas/ water metering, are relatively insensitive to differences in well depth. Other cost items, such as production casing, tubing, and the pumping system, are directly related to well depth.

Based on the itemization of fixed and variable costs, the drilling and completion cost equation for a shallow (less than 1,000 foot) PRB CBM well is as follows:

$(\$ 27,000+\$ 28(\mathrm{WD})) * 1.10$

where: WD is well depth $\leq 1,000$ feet

As well depth increases, well drilling and completion costs rise to account for the extra costs involved with increasing depth. Based on experiences in the PRB and other CBM basins, we would estimate the cost equation for deeper, 1,000- to 3,000-foot CBM wells as follows:

$$
(\$ 27,000+\$ 28(1,000)+\$ 56(\mathrm{WD}-(1,000)) * 1.10
$$

where: WD is well depth $<3,000$ feet

Using the above equation, the well drilling and completion costs for the example 600 -foot PRB CBM well and two deeper PRB CBM wells, one at 1,500 feet and one at 2,000 feet, are calculated as follows:

$$
\begin{aligned}
& (\$ 27,000+\$ 28(600)) * 1.10=\$ 48,180 \\
& (\$ 27,000+\$ 28,000+\$ 56(500)) * 1.10=\$ 91,300 \\
& (\$ 27,000+\$ 28,000+\$ 56(1,000)) * 1.10=\$ 122,100
\end{aligned}
$$

Additional details on specific well drilling and completion costs are provided below. 
Table 4-5. Additional Drilling and Completion Costs for Two PRB CBM Wells

\begin{tabular}{|c|c|c|c|}
\hline & Well Depth & $500^{\prime}$ & $850^{\prime}$ \\
\hline \multicolumn{4}{|l|}{ Drilling Costs } \\
\hline Intangible Drilling Costs & & $\$ 24,400$ & $\$ 30,500$ \\
\hline Site Prep, Permit, Survey and ROW & & 3,700 & 3,700 \\
\hline Drilling Rig, Bits, Fluids & & 12,600 & 16,200 \\
\hline Cementing & & 4,200 & 4,400 \\
\hline Logging & & 700 & 800 \\
\hline Supervision (Drilling, Geologic) & & 2,400 & 3,600 \\
\hline Other & & 800 & 1,800 \\
\hline Tangible Drilling Costs & & $\$ 3,800$ & $\$ 6,000$ \\
\hline Surface Casing (9-5/8" @ \$10/ft) & & 600 & 850 \\
\hline Production String (7" @ \$5.50/ft) & & 2,750 & 4,300 \\
\hline Wellhead & & $\underline{450}$ & $\underline{450}$ \\
\hline \multicolumn{4}{|l|}{ Completion Costs } \\
\hline Intangible Completion Costs & & $\$ 4,700$ & $\$ 4,700$ \\
\hline Supervision/Labor & & 2,400 & 2,400 \\
\hline Enhancement & & 1,200 & 1,200 \\
\hline Completion Rig & & 500 & 500 \\
\hline Water Handling & & 600 & 600 \\
\hline Tangible Completion Costs & & $\$ 8,100$ & $\$ 9,600$ \\
\hline Tubing (2" @ \$1.50/ft) & & 800 & 1,300 \\
\hline Pump, Motor, Cable & & 2,500 & 3,500 \\
\hline Electrical Controller/Transducer & & 2,000 & 2,000 \\
\hline Wellhead, Flowline Fittings & & 1,000 & 1,000 \\
\hline \multirow[t]{2}{*}{ Gas and Water Metering } & & 1,800 & 1,800 \\
\hline & Total & $\$ 41,000$ & $\$ 50,800$ \\
\hline
\end{tabular}

\subsubsection{Infrastructure Costs}

Basic Water Handling Facilities. The facilities for gathering and transporting produced CBM water includes a pump and a water metering system (already included in well completion costs) plus small diameter ( 3 inch) polyethylene pipe connected to the tubing of the well. The polyethylene pipe is placed underground in a common trench from the wellhead to a point of common collection. A second, larger diameter (6 inch) polyethylene pipe transports the gathered water to a point of discharge involving a natural drainage outlet or a containment facility. For purposes of the cost estimate, the following assumptions are used: 
- Well pads are placed on 80-acre spacing; on average, two wells exist per well pad; 16 wells ( 8 well pads on one 640 -acre section) are linked together with an underground gathering and piping system.

- $\quad$ For cost estimation purposes, each well initially produces 400 BWD (in year 1) declining to $240 \mathrm{BWD}$ in year 2 and declining by $25 \%$ each subsequent year. Total water production is 470,000 barrels per well for the 10 years of a well's life. (For this example well, average water production is about $4 \mathrm{gpm}$ (137 barrels per day) for 10 years.)

- $\quad$ Approximately 2,000 feet of 3-inch polyethylene pipe is required for each well; 2 lines, each using approximately 5,000 feet of 6 -inch polyethylene pipe, link the 16-well unit to 2 water disposal sites.

- $\quad$ Approximately 32,000 feet of common trenching is required for water gathering (as well as the electrical cable and small-diameter gas-gathering lines) and 10,000 feet of common trenching is required for water transportation (as well as for gas transmission).

- The cost for trenching and the survey is estimated at $\$ 2.15$ per foot; the cost of the polyethylene pipe is estimated at $\$ 0.50$ to $\$ 0.70$ per foot; and, the cost for right of way (ROW) is estimated at $\$ 0.60$ per foot.

The cost of the water gathering and subsurface piping system for a 16-well unit is estimated at $\$ 163,350$ or $\$ 10,210$ per well, based on the following:

- $\quad$ Trenching and Survey: $(42,000 \mathrm{ft} @ \$ 2.15 \mathrm{ft})$

- Water Gathering: 3 inch poly pipe $(32,000 \mathrm{ft} @ \$ 0.50 / \mathrm{ft}$.)

$$
\begin{array}{ll}
= & \$ 90,300 \\
= & \$ 16,000 \\
= & \$ 7,000 \\
= & \$ 10,000 \\
= & \$ 25,200 \\
= & \quad \$ 14,850 \\
& \$ 163,350
\end{array}
$$$$
\text { - Water Transport: } 6 \text { inch poly pipe }(10,000 \mathrm{ft} @ \$ 0.70 / \mathrm{ft} \text {.) }
$$$$
\text { - } \quad \text { Surface Pump: (2 units@\$5,000/unit) }
$$

- $\quad$ Right of Way: (42,000 ft. @ \$0.60/ft.)

- Contingency, insurance, etc. (@10\%)

Operating and maintenance costs for the water gathering and transportation system, including electric power, surface pump maintenance and other costs, are included in the O\&M costs for surface discharge, are discussed later.

Electric Power. The costs of providing three-phase electric power and electrical cable to a 16-well unit (without trenching and survey) are as follows:

$\begin{array}{cr}\text { - } \quad \text { Central 3-Phase Power* } & \$ 75,000 \\ \text { - } \quad \text { Electric Cable (32,000 ft. @ \$1.50/ft.) } & \frac{48,000}{\$ 123,000} \\ \text { - } \quad \text { Contingency, insurance, etc. (@10\%) } \\ \text { Total } & \frac{12,300}{\mathbf{\$ 1 3 5 , 3 0 0}}\end{array}$

* Costs can range from $\$ 50,000$ to $\$ 100,000$, depending on location.

Based on 16 wells, the cost per well is estimated at $\$ 8,450$. 
Gas Gatherings. The costs of providing gas gathering and central gas transmission for the 16-well unit to a central compressor (without trenching and survey) are as follows:

- $\quad$ Gas Gathering: (32,000 ft., 4" @ \$0.90/ft.)

- $\quad$ Gas Transmission: (10,000 ft, 12" @ \$8.50/ft.)

- $\quad$ Contingency, insurance, etc. (@10\%)

Total
$\$ 28,800$

85,000

$\$ 113,800$

11,380

$\$ 125,180$

Based on 16 wells, the cost per well is estimated at $\$ 7,820$.

\subsection{Discussion of CBM Well O\&M Costs}

\subsubsection{O\&M Costs for PRB CBM Well}

Well and lease operating and maintenance (O\&M) costs in the PRB are for electricity, wages for the pumper and miscellaneous site maintenance. In addition, particularly during the initial years of operation, CBM wells require periodic replacement of the downhole water pumping system and remediation.

The cost model assumes two pump replacements and a well workover during the first year of operation, an annual pump replacements during the next three years of operation (but no additional well workover), and annual pump replacement with a smaller capacity pump during the final 6 years of operation.

The costs for water lifting capacity depends on well depth and the water rate, as provided below:

Table 4-6. Pump Replacement Costs

\begin{tabular}{|c|c|c|}
\hline Pump Size (bwpd) & Pump Cost $(\$)$ & ${\text { Rig }(\$)^{* *}}^{*}$ \\
\hline 171 & 1,100 & 500 \\
\hline 342 & 1,365 & 500 \\
\hline 684 & 2,115 & 500 \\
\hline 1,028 & 2,865 & 500 \\
\hline 1,371 & 3,696 & 500 \\
\hline
\end{tabular}

* Pump size of 171 to 684 bwpd are sufficient for well depths from 300 to 1,000 feet; pump size 1,028 to 1,371 bwpd are required for well depths below 1,000 feet.

** The cost for the workover rig assumes replacements of two pumps per day.

The annual O\&M costs for electricity are scaled by water production rates of the CBM well, with 305 barrels per day (average for the year) incurring $\$ 3,050$ annual costs for electricity.

The cost of replacement plumps is scaled by well depth and varies in time by changing waterletting capacity requirements. 
The annual cost for pump replacement for well depths from 300 to 1,000 feet is provided above. The cost for pump replacement for well depths below 1,000 feet is established by multiplying the pump replacement costs for 1,000-foot wells by the following cost scaling factor:

- $\quad$ Pump Replacement Cost (for $1,000^{\prime}$ well) * (WD/1,000' $)^{2}$

- $\quad$ For WD of 1,000' to 3,000'

The annual and monthly direct well and lease O\&M costs for a PRB CBM well at 600 feet of depth and producing 305 barrels of water per day in year 1 (declining with time), are provided below, by year of operation:

$\underline{\text { Year } 1}$

Electricity

Pumper

Workover*

$1^{\text {st }}$ Pump Replacement

$2^{\text {nd }}$ Pump Replacement

Annual ROW

Misc.

\begin{tabular}{|c|c|}
\hline Annual & Monthly \\
\hline$\$ 3,050$ & \\
\hline 1,140 & \\
\hline 6,270 & \\
\hline 2,620 & \\
\hline 2,620 & \\
\hline 700 & \\
\hline$\underline{300}$ & \\
\hline$\$ 16,700$ & $\$ 1,390$ \\
\hline$\$ 20,040$ & $\$ 1,670$ \\
\hline
\end{tabular}

***Total w/G\&A

\section{Year 2-4}

Electricity****

Pumper

Pump Replacement

Workover**

Annual ROW

Misc.

$\begin{array}{rrr} & \$ 1,500 \\ 1,140 & \\ 1,860 & \\ 2,000 & 700 & \\ & \underline{300} & \$ 625 \\ \text { Total } & \$ 7,500 & \$ 750 \\ & \$ 9,000 & \\ & \$ 480 & \\ & 1,140 & \\ & 1,600 & \\ & 700 & \\ & \underline{280} & \$ 350 \\ & \$ 4,200 & \$ 420 \\ \text { Total w/G\&A } & \$ 5,040 & \end{array}$

* Each well is assumed to require one re-enhancement to restore productivity during the first year.

** One out of three wells is assumed to require a clean-out during their second year.

${ }^{* * *} A$ G\&A cost of $20 \%$ is added to the well and lease O\&M costs, annual and monthly costs are rounded.

${ }^{* * * *}$ Electricity costs are scaled based on annual water production. 


\subsection{ECONOMICS OF POWDER RIVER COALBED METHANE WITH ALTERNATIVE WATER MANAGEMENT OPTIONS}

\subsection{Summary}

\subsubsection{Key Economic Factors}

The economics of coalbed methane produced water management in the Powder River Basin are influenced by four key factors:

- $\quad$ Future natural gas prices and, most critical today, the "basin differential." While natural gas prices at the Henry Hub have recently ranged from $\$ 3$ to $\$ 3.50$ per Mcf, the prices paid at the Wyoming hubs have ranged from $\$ 1$ to $\$ 1.50$ per Mcf, for an unprecedented and persistent "basin differential" of $\$ 1.50$ to $\$ 2.00$ per Mcf.

- The volume and timing of gas and water production from individual coal seams in distinct portions of the basin. Expected gas recovery from a CBM well ranges by order of magnitude, from $0.1 \mathrm{Bcf}$ to $1 \mathrm{Bcf}$ per well; and, water recovery varies twenty-fold, from 100,000 to $2,000,000$ barrels per well.

- The capital and O\&M costs for drilling and operating wells of different gas and water productivity and at depths of 300 to 3,000 feet.

- The coalbed methane produced water management option selected by the operator, as discussed further below.

\subsubsection{Economic Cases}

To examine the economic impact of alternative water production practices, the study used three gas price and "basin differential" cases:

Case 1 (Today). Case 1 assumes long-term natural gas prices of $\$ 3.00$ per Mcf (in constant year 2002 prices) at the Henry Hub, with a basin differential of $\$ 1.80$ per Mcf. This provides a natural gas price at the Wyoming Hub of $\$ 1.20$ per Mcf. (As a point of reference, on July 1 , 2002 the natural gas price at the Wyoming Hub was \$1.07 per MMBtu, with a Henry Hub price of $\$ 3.20$ per MMBtu.)

Case 2 (Transition). Case 2 uses the same gas price (at Henry Hub) as Case 1, but assumes that the "basin differential" narrows with time, from $\$ 1.80$ per Mcf today, to $\$ 1.30$ per Mcf in 2003 , and to $\$ 0.80$ per Mcf in 2003 and beyond.

Case 3 (Long Term). Case 3 uses the same gas price (at Henry Hub) as Cases 1 and 2, but assumes that the "basin differential" is and remains at $\$ 0.80$ per Mcf, consistent with historical trends.

For the volumes of gas and water expected to be produced, the study uses the 142 type wells representative of the different geological areas and coal seams in the PRB, presented in 
Chapter 3. For capital and O\&M costs, the study uses the cost and economic models presented in Chapter 4.

\subsubsection{Overview of Economic Analyses}

The economics of alternative water management options in the PRB are as follows, using a 15\% (before corporate income tax) internal rate of return (IRR) as the threshold criteria.

\section{Table 5-1. Volumes of Economically Recoverable CBM w/Alternative Water Disposal Options*}

\begin{tabular}{|l|c|c|c|c|}
\hline Economic Cases & $\begin{array}{c}\text { Surface } \\
\text { Discharge }\end{array}$ & Impoundment & $\begin{array}{c}\text { Shallow } \\
\text { Reinjection }\end{array}$ & $\begin{array}{c}\text { Active } \\
\text { Treatment }\end{array}$ \\
\hline Case 1 (Today) & $1.5 \mathrm{Tcf}$ & -- & -- & -- \\
\hline Case 2 (Transition) & $22.4 \mathrm{Tcf}$ & $20.0 \mathrm{Tcf}$ & $18.8 \mathrm{Tcf}$ & $7.1-10.2 \mathrm{Tcf}$ \\
\hline Case 3 (Long Term) & $29.1 \mathrm{Tcf}$ & $27.8 \mathrm{Tcf}$ & $27.1 \mathrm{Tcf}$ & $17.8-21.6 \mathrm{Tcf}$ \\
\hline
\end{tabular}

* Includes the 655 Bcf of CBM produced to date from the basin.

Analyses of the economics of alternative water management options for PRB CBM show the following:

Case 1 (Today). Under today's unfavorable economics (Case 1), surface disposal of produced water is the only economic water management option, and even this option is economic only in selected, high quality portions of the PRB. More costly water disposal options would preclude further economic development of coalbed methane in the Powder River Basin. A significant portion of the $1.5 \mathrm{Tcf}$ of economic CBM potential shown in the above table is already under development with about 650 Bcf of this volume produced to date, leaving little opportunity for further economically justified expansion in this basin under today's gas price and PRB "basin differential."

Case 2 (Transition). Assuming a transition toward more normal Wyoming basin price differentials, a significant portion of the basin becomes economic to develop with water management practices of surface discharge, impoundment or shallow re-injection. Requiring active treatment of the produced water (with current reverse osmosis technology) greatly reduces the basin's economic potential. Specifically, instead of 19 to 22 Tcf of economically recoverable coalbed methane (using one of the first three water management options), only 7 to $10 \mathrm{Tcf}$ of coalbed methane remains economic to develop with a requirement for active water treatment. This represents a loss of 12 Tcf of otherwise economically recoverable natural gas resource.

Case 3 (Long Term). Using a long-term outlook for gas prices in Wyoming (requiring that development be delayed until the basin differential reaches historically more normal values), the economic CBM resources of the PRB range from 27 to $29 \mathrm{Tcf}$ (for the three lower cost water management options). Imposing active treatment of water (with current reverse osmosis tech- 
nology) reduces the economically viable PRB CBM potential to a range of 18 to $22 \mathrm{Tcf}$, for a loss of 7 to 9 Tcf natural gas resources.

\subsubsection{Impact of Risk Premium}

Using a higher minimum rate of return - one potentially more reflective of the current higher economic and regulatory risks in the $\mathrm{PRB}$ - would reduce the natural gas resource and production contribution from the PRB. Imposing higher cost water management options, such as active produced water treatment with reverse osmosis, and a higher risk premium would also preclude further economic development of coalbed methane in the PRB. The result of this risk premium analyses, using Case 2 natural gas wellhead price and basin differential assumption, is shown below:

\section{Table 5-2. Volumes of Economically Recoverable CBM w/Alternative Water Disposal Options}

\begin{tabular}{|c|c|c|}
\hline Water Management Options & $\begin{array}{c}\text { Case } 2 \\
\text { w/15\% IRR } \\
\text { Treshold }\end{array}$ & $\begin{array}{c}\text { Case 2 } \\
\text { w/25\% IRR } \\
\text { Threshold }\end{array}$ \\
\hline Surface Discharge & 22.4 Tcf & 16.6 Tcf \\
\hline Impoundment & 20.0 Tcf & 12.7 Tcf \\
\hline Shallow Reinjection & 18.8 Tcf & 12.4 Tcf \\
\hline \multicolumn{3}{|l|}{ Active Treatment } \\
\hline w/Trucking & 7.1 Tcf & $0.8 \mathrm{Tcf}$ \\
\hline w/Deep Disposal & 10.2 Tcf & $2.1 \mathrm{Tcf}$ \\
\hline
\end{tabular}

\subsection{Water Disposal Alternatives}

A series of alternatives are being used or considered for CBM water disposal in the Powder River Basin, including:

- $\quad$ Untreated or passively treated water with surface discharge.

- Infiltration impoundment with enhanced evaporation and/or land application.

- Shallow re-injection of the produced water.

- $\quad$ Actively treated water with infiltration, evaporation, land application, and/or surface discharge, and disposition of the residual concentrate by trucking or deep re-injection.

Deep re-injection of the untreated, relatively high quality CBM produced water would be wasting a valuable resource and thus has not been included among the water disposal alternatives in this study. 


\subsection{Costs of Water Disposal Alternatives}

\subsubsection{Capital Costs}

The capital costs for the alternative CBM water disposal options add from $\$ 1,400$ to $\$ 35,200$ per well, depending on the water management alternative selected, as shown for the example well below.

Table 5-3. CBM Water Disposal Alternative Costs

\begin{tabular}{|c|c|c|}
\hline & \multicolumn{2}{|c|}{ Water Disposal Costs } \\
\hline & Capital Costs/Well & O\&M Costs/Bbl.* \\
\hline \multicolumn{3}{|l|}{ Water Disposal } \\
\hline Surface Discharge & $\$ 1,400$ & $\$ 0.02$ \\
\hline Infiltration Impoundment & $\$ 10,300$ & $\$ 0.06$ \\
\hline Shallow Re-Injection & $\$ 15,150$ & $\$ 0.06$ \\
\hline \multicolumn{3}{|c|}{$\begin{array}{l}\text { Active Treatment w/Disposal of } \\
\text { Residual Concentrate }\end{array}$} \\
\hline Trucking & $\$ 19,600$ & $\$ 0.24$ \\
\hline Deep Re-Injection & $\$ 35,200$ & $\$ 0.14$ \\
\hline
\end{tabular}

*Per barrel of water produced for a "typical" CBM producing 320 barrels per day (average) during the first 2 years.

\subsubsection{O\&M Costs}

The operating costs of alternative CBM water disposal options will add from $\$ 0.02$ to $\$ 0.24$ per barrel of produced water to basic well and lease O\&M costs, depending on the water management alternative selected.

\subsubsection{Capital Costs for Water Treating and Associated Disposal}

The total capital costs for using active water treatment (with RO) are as follows for a 900-gpm (30,860 barrel per day) facility: 
Table 5-4. Capital Costs for Disposal Options

\begin{tabular}{|c|c|c|}
\hline & Trucking & Deep Disposal \\
\hline Three RO Unit (installed) & $\$ 1,600,000$ & $\$ 1,600,000$ \\
\hline Deep Disposal well and facilities & - & $\$ 1,500,000$ \\
\hline Three Impoundments & $\$ 150,000$ & $\$ 150,000$ \\
\hline Three surface discharge points & $\$ 130,000$ & $\$ 130,000$ \\
\hline TOTAL & $\$ 1,880,000$ & $\$ 3,380,000$ \\
\hline
\end{tabular}

The cost for the RO unit and associated facilities, assuming trucking of the residual concentrate to disposal, is $\$ 1,880,000$ or $\$ 19,600$ per well for a 96 -well unit.

Using a deep disposal well and injection facilities would eliminate the costs of trucking the residual concentrate, but would raise the capital costs to $\$ 3,380,000$ or $\$ 35,200$ per well for a 96-well unit.

\subsubsection{Operating Costs for Water Treatment and Associated Disposal}

Operating costs for the three RO units are estimated at $\$ 233,100$ per year for a 96-well unit, or $\$ 0.02$ per barrel of water treated (assuming a capacity of 30,000 barrels per day), and an operating factor of $95 \%$. Adding the costs of maintaining the discharge points and impoundments, and providing electricity and maintenance for the pumps, bring operating costs to $\$ 0.04$ per barrel of water produced.

For trucking, the total costs are estimated at $\$ 0.24$ per barrel of water produced, assuming water trucking costs of $\$ 2.00$ per barrel and $10 \%$ residual concentrate.

For deep disposal, the total costs are estimated at $\$ 0.14$ per barrel of water produced, assuming deep re-injection well and facility O\&M costs of $\$ 0.10$ per barrel of water injected.

Table 5-5. Total Estimated Costs for Deep Disposal

\begin{tabular}{|l|r|}
\multicolumn{1}{c|}{} & \multicolumn{1}{c|}{$\begin{array}{c}\text { Annual } \\
\text { Operating Costs* }\end{array}$} \\
\hline Electric Power & $\$ 57,000$ \\
\hline Chemicals & $\$ 73,000$ \\
\hline Anti-scalant & $\$ 5,000$ \\
\hline Cleaning & $\$ 3,500$ \\
\hline Iron removal & $\$ 33,600$ \\
\hline Membrane Replacement (After 5 years, annualized) & see below \\
\hline Reject Disposal (10\% residual concentrate) & $\$ 22,000$ \\
\hline Annual Labor & $\$ 194,200$ \\
\hline & \\
\hline G\&A of 20\% & TOTAL \\
\hline & $\$ 233,800$ \\
\hline
\end{tabular}

${ }^{*}$ Assuming a 96-well unit. 


\subsection{Discussion of Water Disposal Capital and O\&M Costs}

\subsubsection{Surface Discharge}

This alternative involves building two water discharge points with limestone rock (rip-rap) for passive treatment of the produced water. (The cost for the water transportation system and pumps has been included above.)

- The cost for 20 cubic yards of limestone rock is estimated at $\$ 600$.

- $\quad$ The cost for building a discharge point is estimated at $\$ 5,000$.

- $\quad$ Contingency, insurance, and other costs of $10 \%$ are added to the above.

- The cost for the NPDES permit is approximately $\$ 1,000$ per well.

- The total cost is estimated at $\$ 6,200$ for a 16 -well facility or $\$ 400$ per typical CBM well, plus $\$ 1,000$ per well for the NPDES permit.

The operating costs for monitoring surface discharge, including electricity and maintenance for the surface pumps, are estimated at $\$ 0.02$ per barrel.

\subsubsection{Infiltration Impoundment}

This alternative involves constructing an impoundment (pond) and installing enhanced evaporation equipment (atomizers) or a surface irrigation system.

- The size of the impoundment is 3 acres with a dam of 13 feet, providing 20 acre-feet (150,000 barrels) of water capacity sufficient to hold 30 days of production from a 16-well unit.

- Annual water infiltration is estimated at 8 feet of water loss per year, with enhanced evaporation and surface irritation providing 12 feet of water loss per year. Together, this provides 60 acre-feet (approximately 465,000 barrels) of water loss per year or about 1,275 barrels per day (with more during summer months and less during winter months).

- An irrigation or atomizing system is added to the impoundment. One such unit is able to dispose of $45 \mathrm{gpm}$ or 1,500 barrels per day.

- At an average water rate of 320 barrels per day (during the first two years of well operation), the 16-well unit will produce about 5,000 barrels per day of water. One impoundment with an irrigation system will accommodate about 8 wells (and more wells during subsequent years). A 16-well unit requires two such infiltration and evaporation impoundments. 
- The cost for constructing each impoundment is estimated at $\$ 25,000$ to $\$ 50,000$, based on handling approximately 50,000 cubic yards of material at $\$ 0.50$ to $\$ 1.00$ per cubic yard. (Reclamation costs of $\$ 10,000$ (on a present value basis) are added to this total).

- The cost for one atomizer or irrigation system is estimated at $\$ 16,500$ for a 1,500 -barrels per day (45 gpm) unit, with installation costs of about $20 \%$ or $\$ 3,500$. Two such units are required.

- Contingency, insurance, right of way and other costs of $10 \%$ are added.

- The total cost for two infiltration and evaporation impoundments is $\$ 148,500$, or $\$ 9,300$ per typical CBM well plus $\$ 1,000$ per well for the NPDES permit.

\begin{tabular}{lr} 
Construction & $\$ 75,000$ \\
Reclamation (PV) & 20,000 \\
Atomizers/Irrigation (2 units) & 40,000 \\
Contingency, etc. & 13,500 \\
\hline 148,500
\end{tabular}

The operating cost for the infiltration and evaporation impoundment is estimated at $\$ 0.06$ per barrel of water produced, including $\$ 0.02$ per barrel for electricity and maintenance for the surface pumps and $\$ 0.04$ per barrel for operating the irrigation system and maintaining the impoundment.

\subsubsection{Shallow Re-injection}

This alternative involves identifying shallow, ideally relatively fresh water zones into which the $\mathrm{CBM}$ produced water could be re-injected. A handful of such shallow well injection projects exist, but with a mixed record of success. Basically, shallow re-injection is a high risk option and may be considered a speculative alternative at this time. Therefore, shallow re-injection was evaluated from a theoretical standpoint in this analysis.

Ideally, the shallow re-injection zone would be under pressured and highly permeable. This would help reduce (or eliminate) pumped costs and reduce the number of required injection wells.

The costs for a large, central shallow re-injection facility (or two smaller facilities) capable of dispersing 30,000 barrels per day from 96 producing CBM wells is as follows:

- The cost of two 3-acre (20 acre-foot) infiltration impoundments (with a combined capacity fo 300,000 barrels) is estimated at $\$ 104,500$. This would provide storage for about 10 days of water production from a 96-well unit. The annual water loss from two impoundments would be modest, the order of 1,500 barrels per day.

- $\quad$ The remainder of the produced water would be injected into a series of shallow wells. Assuming water injection capacity of 2,000 barrels per day (based on water production 
and a select number of injection projects in the basin), approximately 15 shallow wells would be required.

- The drilling and completion costs for shallow wells estimated to be on the order of $\$ 30,000$ to $\$ 70,000$ per well. Adding other costs, such as water transportation, pumps, injection facilities, permits, etc., is estimated to be about $\$ 30,000$ to $\$ 50,000$ per well, and provides total well costs of $\$ 90,000$ (Source: CBM Producers Information Survey Results, January 2002).

- Assuming average shallow well drilling and completion costs per well of $\$ 90,000$, the costs for 15 wells would be $\$ 1,350,000$ plus $\$ 104,500$ for the impoundment facilities for a total of $\$ 1,454,500$ or $\$ 15,150$ per typical CBM well, as shown below:

Impoundments (2) \$ $\quad$ 104,500

Shallow Wells (10) $\$ \$ 1,350,000$

Total $\$ 1,454,500$

The operating costs for the shallow wells and impoundment (including electricity and maintenance for the surface pumps) are estimated at $\$ 0.06$ per barrel of water produced.

\subsubsection{Active Treatment Using Reverse Osmosis}

This alternative involves constructing water holding and residual concentration storage impoundments, installing a water treatment system involving reverse osmosis (RO), surface discharging the treated water, and either trucking or deep re-injecting the residual concentrate.

Capital Costs. The capital costs are for a large, central unit able to service 96-producing CBM wells.

- $\quad$ The cost of three surface discharge points is estimated at $\$ 18,600$ (from above), plus $\$ 15,000$ for water piping and $\$ 96,000$ for studies and permits, for a total of $\$ 130,000$ for a 96-well unit.

- The cost of one 3-acre (20 acre-foot) infiltration impoundment (with a capacity of 150,000 barrels) is estimated at $\$ 52,250$ (from above). This would provide storage for about 5 days of water production from a 96-well unit. Two such impoundments are required to provide 10 days of produced water storage capacity. The cost of a third smaller (10 acre-foot) lined impoundment for storing the reject water (concentrate) from the RO unit is estimated at $\$ 32,000$, plus piping. This would provide storage for up to one month of reject water. The total cost for impoundments is estimated at $\$ 150,000$.

- $\quad$ Assuming a 96-well unit and 320 barrels of water per day per well (average water rate for first 2 years), 3 300-gpm (10,286 barrel per day) units are required with capacity to treat 30,000 barrels per day. 
- The cost for $3 \mathrm{RO}$ units (from Filter Tech) is $\$ 1,212,000$. Assuming 20\% for site preparation, the electrical system, building, etc., plus 10\% for contingency, insurance and other, the cost for three units is $\$ 1,600,000$.

- Two options, trucking and deep disposal, exist for disposing of the residual concentrate, estimated at $10 \%$ of the treated water, or 3,000 barrels per day.

- If trucking is the option, these costs are included in O\&M costs, presented in the next section.

- If disposal is the option, additional capital costs are required for a deep disposal well and an injection facility for the residual concentrate. The costs of the re-injection well and associated facilities are estimated at $\$ 1,000,000$ for the deep re-injection well and $\$ 500,000$ for the facility (including large capacity pumps, electricity, water transportation and other costs).

The total capital costs for using active water treatment (with RO) are as follows for a 900-gpm (30,860 barrel per day) facility:

Table 5-6. Total Capital Costs for Active Water Treatment

\begin{tabular}{|l|r|r|}
\cline { 2 - 3 } \multicolumn{1}{c|}{} & \multicolumn{1}{c|}{ Trucking } & Deep Disposal \\
\hline Three RO Unit (installed) & $\$ 1,600,000$ & $\$ 1,600,000$ \\
\hline Deep Disposal well and facilities (est.) & - & $\$ 1,500,000$ \\
\hline Three Impoundments & $\$ 150,000$ & $\$ 150,000$ \\
\hline Three surface discharge points & $\$ 130,000$ & $\$ 130,000$ \\
\hline & $\mathbf{\$ 1 , 8 8 0 , 0 0 0}$ & $\mathbf{\$ 3 , 3 8 0 , 0 0 0}$ \\
\hline
\end{tabular}

The cost for the RO unit and associated facilities, assuming trucking of the residual concentrate to disposal, is $\$ 1,880,000$ or $\$ 19,600$ per well for a $96-w e l l$ unit. Adding a deep disposal well and injection facilities would eliminate the costs of trucking the residual concentrate, but would raise the capital costs to $\$ 3,380,000$ or $\$ 35,200$ per well for a 96 -well unit.

Operating and Maintenance Costs. Operating costs for the $3 \mathrm{RO}$ units are estimated at $\$ 233,100$ per year for a 96-well unit, or $\$ 0.03$ per barrel of water treated (assuming a capacity of 30,000 barrels per day) and an operating factor of $95 \%$, as shown below. Adding the costs of maintaining the discharge points and impoundments, and providing electricity and maintenance for the pumps, brings operating costs to $\$ 0.04$ per barrel of water produced.

If trucking is the option, the costs for operating the RO unit, pumping the water, operating the discharge points, and disposing of the residual concentrate are estimated at $\$ 0.24$ per barrel of water produced assuming water trucking costs of $\$ 2.00$ per barrel of residual concentrate and $10 \%$ residual concentrate. 


\section{Table 5-7. Annual Operating Costs for Trucking}

\begin{tabular}{|c|c|}
\hline & $\begin{array}{c}\text { Annual } \\
\text { Operating Costs* }\end{array}$ \\
\hline Electric Power & $\$ 57,000$ \\
\hline \multicolumn{2}{|l|}{ Chemicals } \\
\hline Anti-scalant & $\$ 73,000$ \\
\hline Cleaning & $\$ 5,000$ \\
\hline Iron removal & $\$ 3,500$ \\
\hline Membrane Replacement (After 5 years, annualized) & $\$ 33,600$ \\
\hline Reject Disposal (10\% residual concentrate) & see below \\
\hline \multirow[t]{2}{*}{ Annual Labor } & $\$ 22,000$ \\
\hline & $\$ 194,200$ \\
\hline G\&A of $20 \%$ & $\$ 38,800$ \\
\hline & $\$ 233,000$ \\
\hline
\end{tabular}

* Assuming a 96-well unit.

If deep disposal of the residual concentrate is the option, the costs for operating the RO unit, pumping the water, operating the discharge points, and operating and maintaining the deep injection facility are estimated at $\$ 0.14$ per barrel of water produced, assuming deep re-injection well and facility O\&M costs of $\$ 1.00$ per barrel of residual concentrate injected and 10\% residual concentrate.

\subsection{Detailed Economic Analyses of Water Management Options}

An example of the discounted cash flow analysis, prepared for one of the 142 PRB CBM type wells is provided in Table 5-9. The economic analysis is for the Big George coal seam with 97 feet of coal at 1,372 feet of depth, in Partition \#5 of the PRB. The economic assumptions are:

Table 5-8. Assumptions for Discounted Cash Flow Analyses

\begin{tabular}{|l|r|}
\hline Price Calculation & \\
\hline Gas Price (Henry Hub) & $\$ 3.00 /$ Mcf \\
\hline Basin Differential (PRB) & $\$ 1.80$ to \$0.80/Mcf \\
\hline Gathering and Compression & \$0.57/Mcf \\
\hline Net Wellhead Price & \$0.63 to \$1.63/Mcf \\
\hline Sales Volume Adjustment & $(5 \%)$ \\
\hline Btu Adjustment & $(5 \%)$ \\
\hline Lease Fuel & \\
\hline
\end{tabular}


The Big George coal seam in Partition \#5 is estimated to recover 0.7 Bcf of natural gas plus $1,500,000$ barrels of water. Economic analyses of this high water producing seam show that current practices of produced water management enable this coal seam to be economically developed. However, more costly water management options, such as reverse osmosis, will make this major coal seam in Partition \#5 uneconomic. 


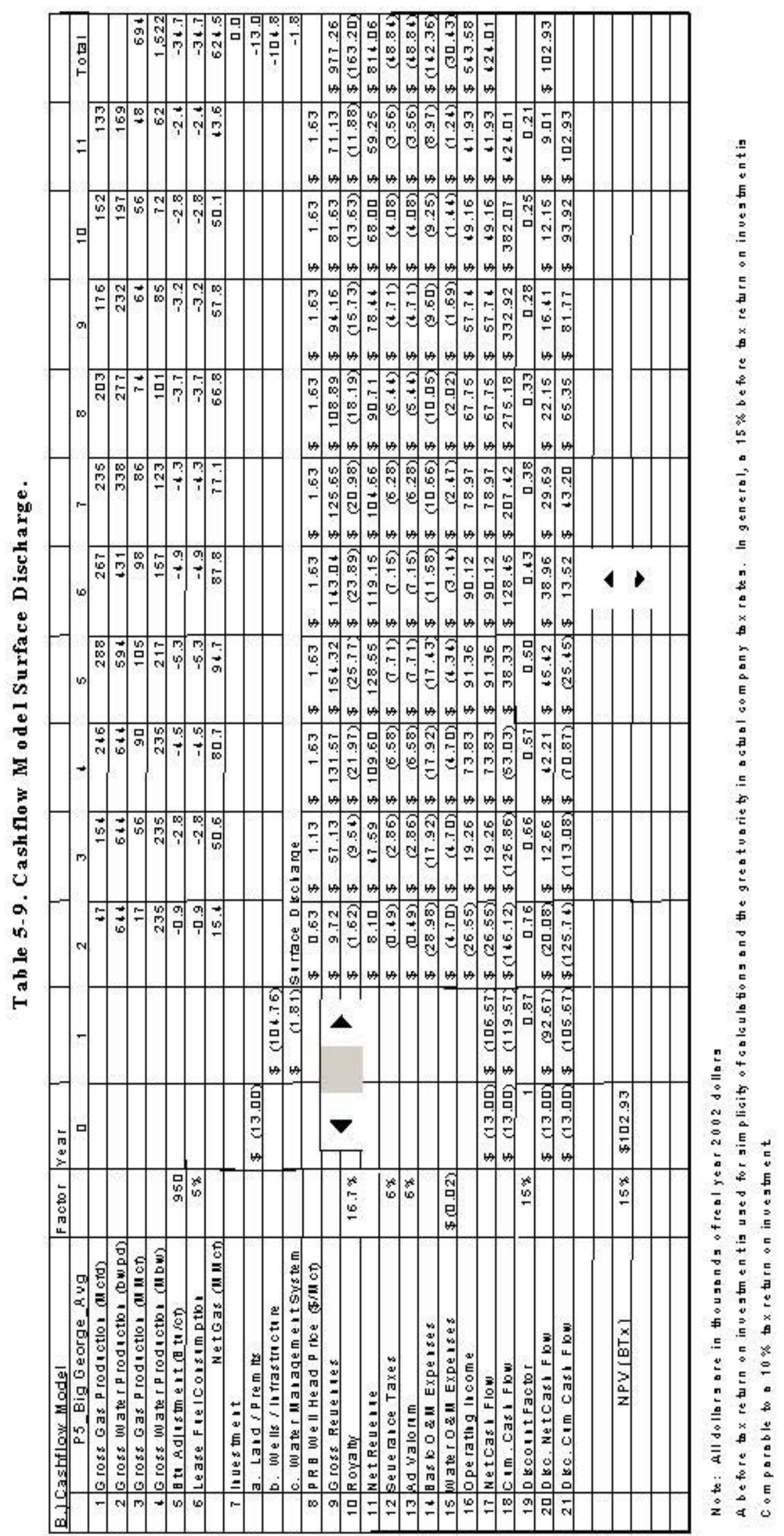

5-12 


\subsection{PRESENTATION OF RESULTS BY BASIN PARTITION}

The materials presented in the previous chapters of the Powder River Coalbed Methane Basin Study provide an overview of the study methodology and findings. Chapter 6 provides a review of this information at a more detailed, "basin partition" level. As such, Chapter 6 contains a series of sections that provide the input data and the discussion of study findings for each of the twelve basin partitions, identified previously ${ }^{1}$. Within each section, additional information is provided on the major Wasatch and Fort Union Formation coal seams present in the partition.

The individual sections in Chapter 6 provide the geologic setting of the partition and its in-place and technically recoverable coalbed methane resources. This is followed by a coal seam by coal seam discussion of key reservoir properties that govern the producibility of each coal seam. Finally, each section presents the distribution of expected gas and water production for major coal seams, as represented by an average, high and low productivity CBM well completed in the seam. A series of maps, tables and figures summarize the data base and analytic work performed on the major coal seams in the Powder River Basin.

Section 6.4 of Chapter 6, discussing the study findings for Partition \#4, contains the full set of maps, type logs, well performance profiles, and reservoir simulation-based history matches that serve as the foundation for the PRB Basin Study. For purposes of brevity, more summary information is provided for the other basin partitions.

\subsection{Partition \#1}

\subsubsection{Summary}

Partition \#1 covers a 20-township area in the southern portion of the Powder River Basin, from $36 \mathrm{~N}$ to $39 \mathrm{~N}$ and from $72 \mathrm{~W}$ to $76 \mathrm{~W}$, Figure 6-1. Only one township in Partition \#1 contains coal that meets the depth and thickness criteria of the study, the Anderson seam with 25 feet of coal at 450 feet. As such, the discussion of the Anderson coal in this partition is combined into Partition \#2, northeast of Partition \#1.

\subsection{Partition \#2}

\subsubsection{Summary}

The main features of Partition \#2, in the southeastern portion of the Powder River Basin, are as follows:

- The partition covers a 17 -township area on the eastern edge of the PRB, from $40 \mathrm{~N}$ to $44 \mathrm{~N}$ and from $70 \mathrm{~W}$ to $73 \mathrm{~W}$, Figure 6-2.

${ }^{1}$ Some quantities have been subject to rounding. 


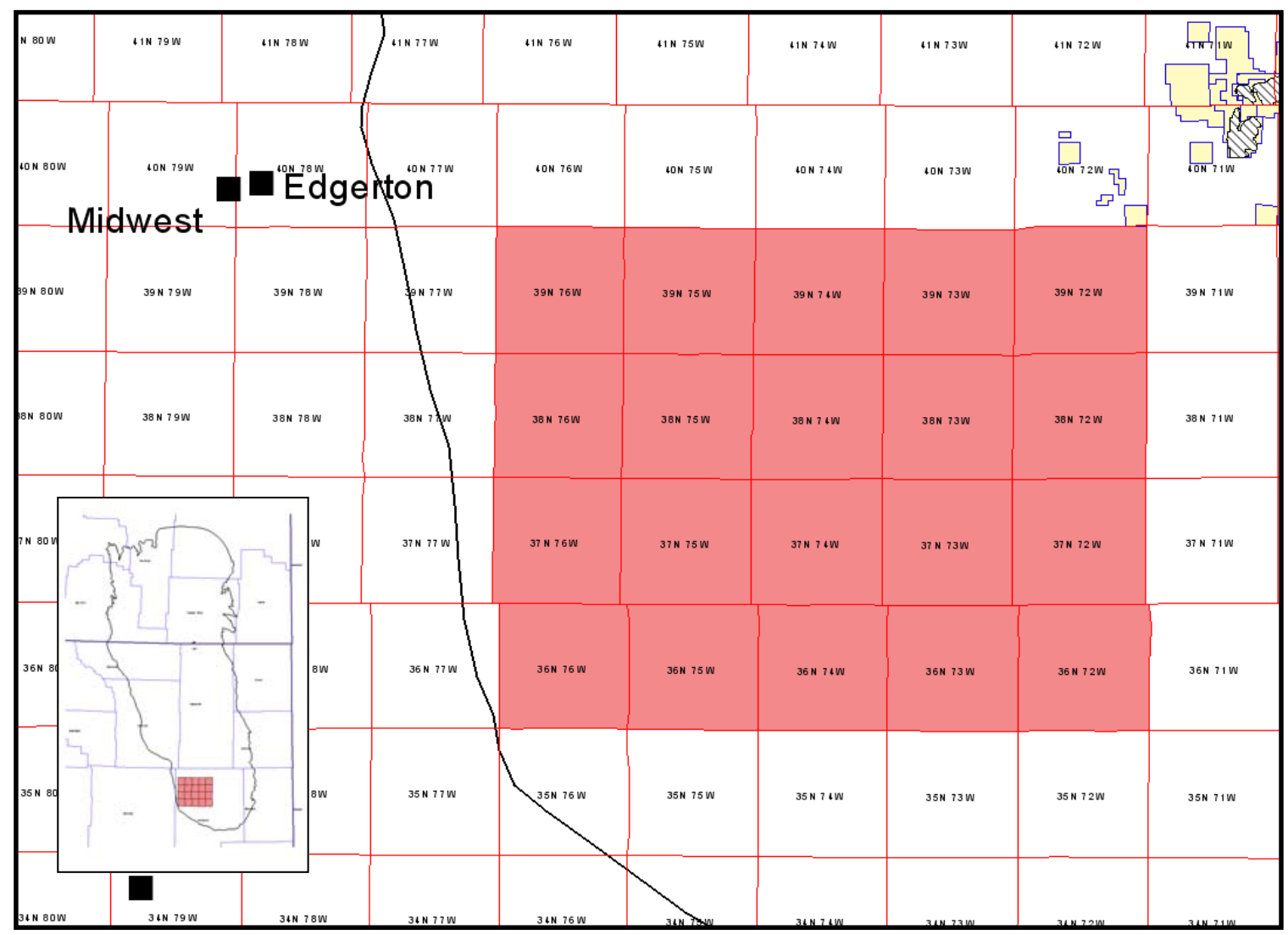

Figure 6-1. Partition \#1 Base Map 


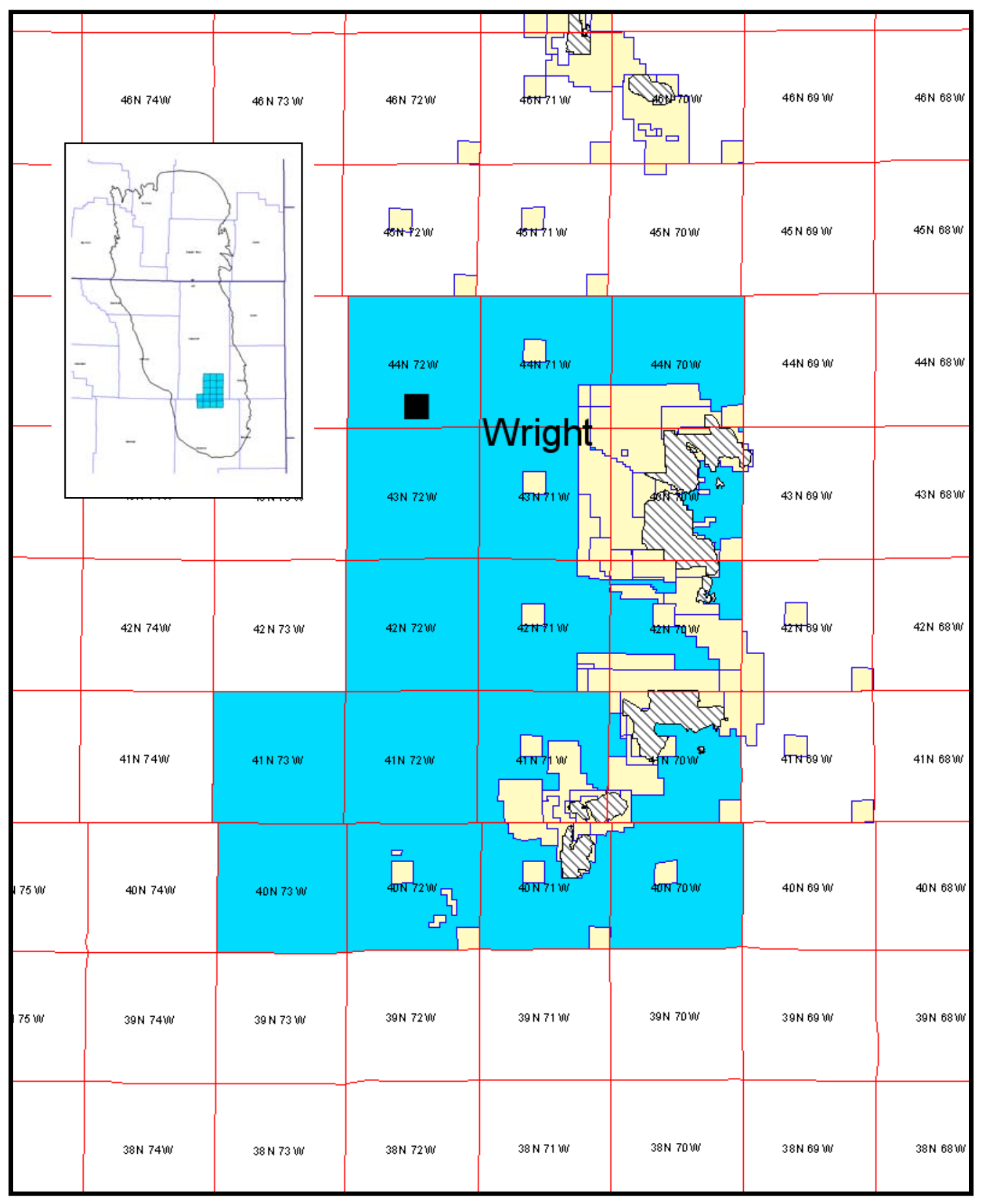

Figure 6-2. Partition \#2 Base Map 
- A series of coal mines exist in the townships along the shallower eastern edge; as a result, the townships on the eastern edge of the partition (in 70W) are no longer available for CBM development.

- The stratigraphic section contains the Canyon, Wyodak, Big George, Cook and Pawnee coal seams (plus the Anderson from Partition \#1). The depth of these coals ranges from 450 to 1,340 feet, with coal seam thickness ranging from 22 to 90 feet (township level averages).

- $\quad$ The gas in-place in the two partitions is $2.2 \mathrm{Tcf}$, with technically recoverable gas of 1,630 Bcf. The results by coal seam are provided in Table 6-7.

\subsubsection{Discussion of Major Seams}

- Anderson. The Anderson is the only significant seam in Partition \#1. It does not meet the depth and thickness criteria in Partition \#2.

- $\quad$ Area. The Anderson coal seam meets study inclusion criteria in 1 township, located in the southern portion of Partition \#1.

- Coal Thickness. The Anderson seam coal thickness averages 25 feet.

- Coal Depth. The depth to the top of the Anderson seam averages 450 feet.

- Development. Only a few Anderson wells currently exist in this partition.

- $\quad$ Time Zero Plot. Not available.

- $\quad$ Type Well. The history-matched Anderson well in Partition \#4, adjusted for depth, gas content and coal thickness, serves as the Anderson type well for Partition \#1.

Table 6-1. Anderson Coal Seam

\begin{tabular}{|l|c|c|c|c|}
\hline Type Well & $\begin{array}{c}\text { Well Depth } \\
\text { (ft) }\end{array}$ & $\begin{array}{c}\text { Coal Thickness } \\
\text { (ft) }\end{array}$ & $\begin{array}{c}\text { Cumulative Gas } \\
\text { Recovery } \\
\text { (Bcf) }\end{array}$ & $\begin{array}{c}\text { Cumulative } \\
\text { Water Recovery } \\
\text { (M bls) }\end{array}$ \\
\hline Average & 475 & 25 & 0.12 & 120 \\
\hline
\end{tabular}

- Canyon. The first major coal seam in Partition \#2 is the Canyon, at times included within or called the Wyodak.

- $\quad$ Area. The Canyon coal seam meets study inclusion criteria in 2 townships located in the western portion of the partition.

- Coal Thickness. The Canyon coal seam thickness averages 48 feet, with a range of 35 to 60 feet. 
- Coal Depth. The depth to the top of the Canyon seam averages 575 feet, with a range of 450 to 700 feet.

- Development. Considerable Canyon coal well development exists in this partition with nearly 100 shut-in and permitted wells.

- $\quad$ Time Zero Plot. The time zero plot for 7 recently drilled Canyon coal wells is provided in Figure 6-3.

- $\quad$ Type Well. Because the Canyon well production data in Partition \#2 is recent, limited and still erratic, the history-matched Canyon well in Partition \#4, adjusted for depth, gas content, and coal thickness, serves as the Canyon type well for Partition \#2. Because only two townships contain the Canyon coal seam, with significantly different coal properties, only a high and low Canyon well are used.

Table 6-2. Canyon Coal Seam

\begin{tabular}{|l|c|c|c|c|}
\hline \multicolumn{1}{|c|}{ Type Well } & $\begin{array}{c}\text { Well Depth } \\
\text { (ft) }\end{array}$ & $\begin{array}{c}\text { Coal Thickness } \\
\text { (ft) }\end{array}$ & $\begin{array}{c}\text { Cumulative Gas } \\
\text { Recovery } \\
\text { (Bcf) }\end{array}$ & $\begin{array}{c}\text { Cumulative } \\
\text { Water Recovery } \\
\text { (M bls) }\end{array}$ \\
\hline High & 760 & 60 & 0.46 & 460 \\
\hline Low & 485 & 35 & 0.17 & 270 \\
\hline
\end{tabular}

- Wyodak. A thick package of Wyodak coals exists in the central portion of Partition \#2.

- $\quad$ Area. The Wyodak coal seam meets study inclusion criteria in 5 townships.

- Coal Thickness. The Wyodak coal seam thickness averages 86 feet, with a range of 70 to 100 feet.

- Coal Depth. The depth to the top of the Wyodak seam averages 440 feet, with a range of 300 to 600 feet.

- Development. Wyodak coal well development is active in this partition with over 500 wells having been drilled or permitted.

- $\quad$ Time Zero Plot. The time zero plot for 181 Wyodak coal wells is provided in Figure 6-4.

- $\quad$ Type Well. Because the Wyodak well production performance in Partition \#2 is similar to the Wyodak well performance in Partition \#4, the history-matched Wyodak well in Partition \#4, adjusted for depth, gas content, and coal thickness, serves as the Wyodak type well for Partition \#2. 


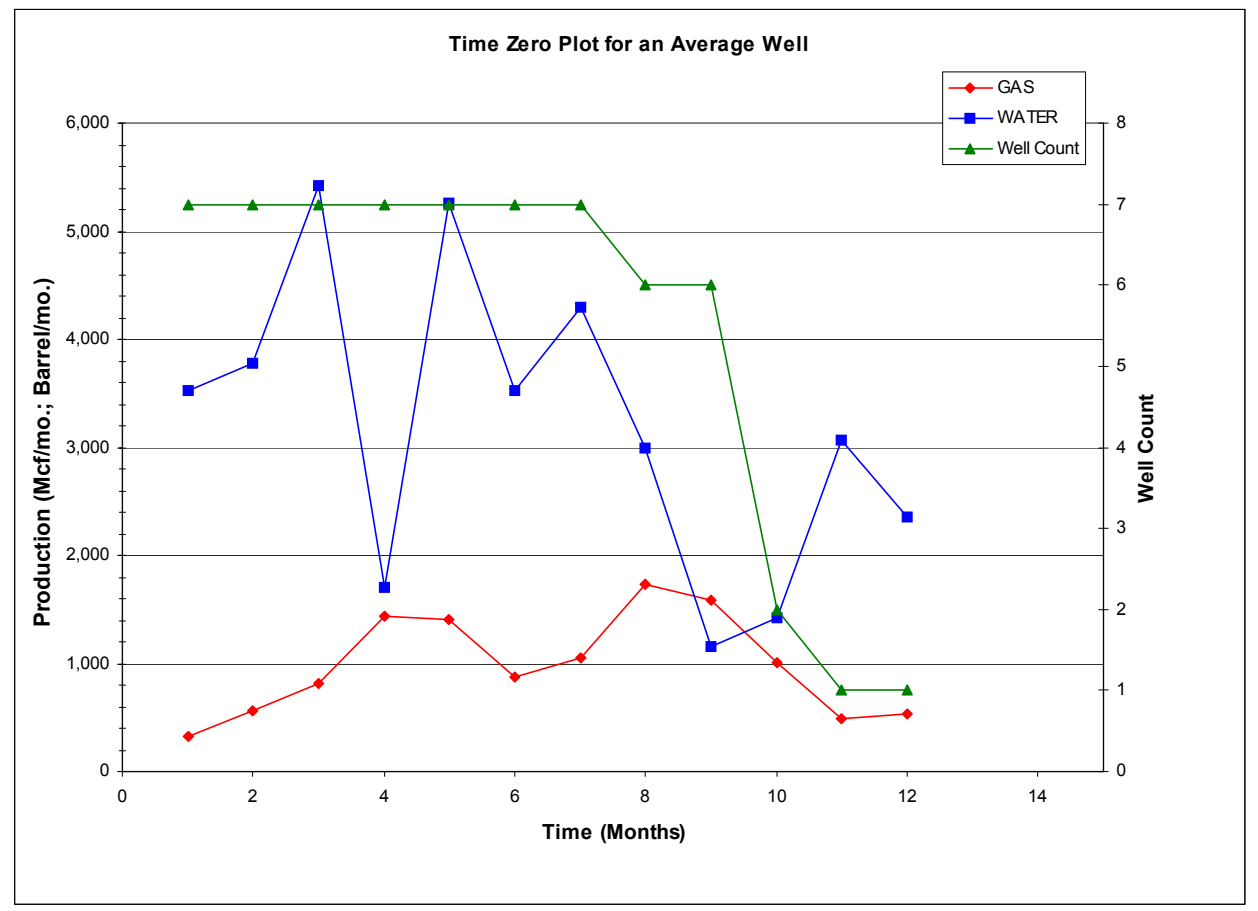

Figure 6-3. Canyon Time Zero Plot 


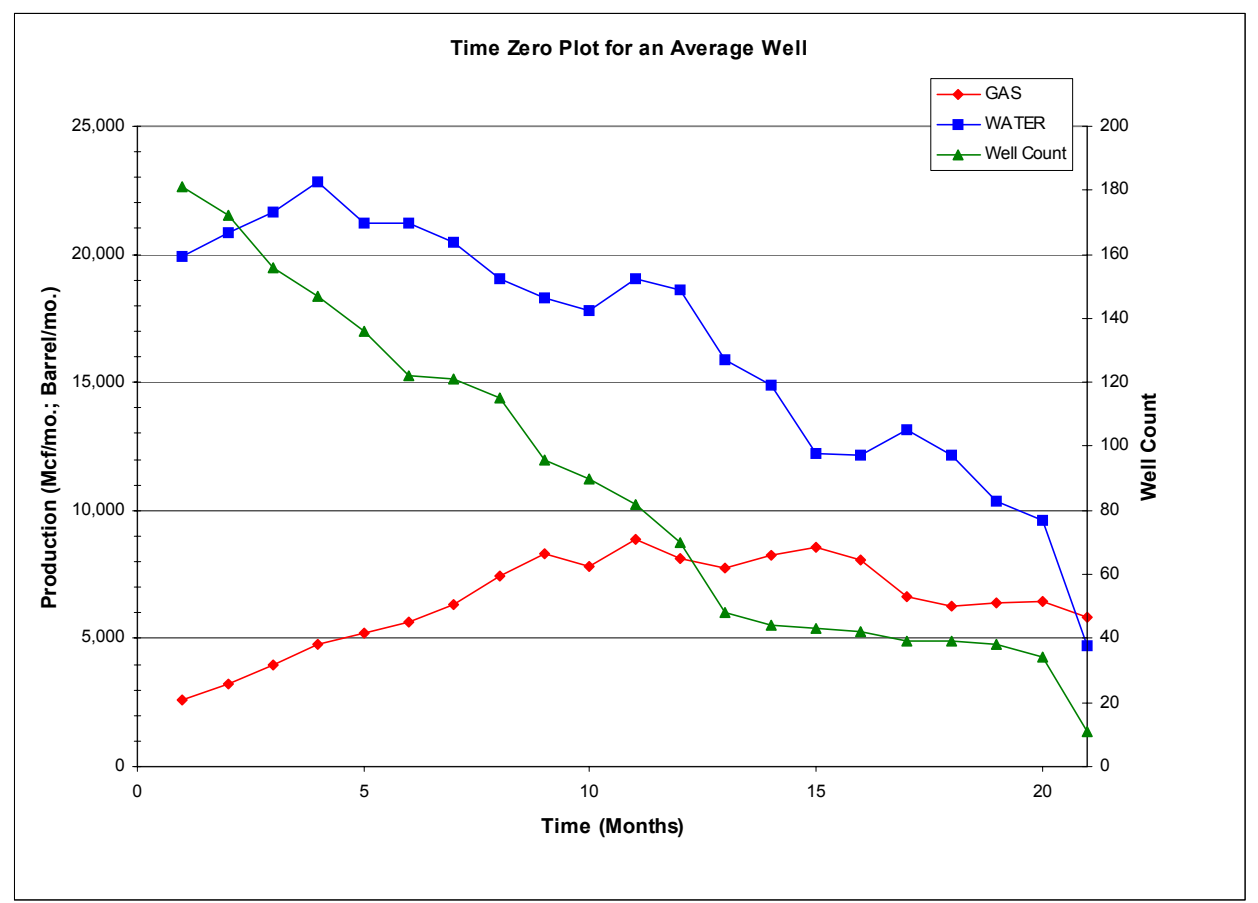

Figure 6-4. Wyodak Time Zero Plot 
Table 6-3. Wyodak Coal Seam

\begin{tabular}{|l|c|c|c|c|}
\hline \multicolumn{1}{|c|}{ Type Well } & $\begin{array}{c}\text { Well Depth } \\
\text { (ft) }\end{array}$ & $\begin{array}{c}\text { Coal Thickness } \\
\text { (ft) }\end{array}$ & $\begin{array}{c}\text { Cumulative Gas } \\
\text { Recovery } \\
\text { (Bcf) }\end{array}$ & $\begin{array}{c}\text { Cumulative } \\
\text { Water Recovery } \\
\text { (M bls) }\end{array}$ \\
\hline Average & 525 & 86 & 0.37 & 1,140 \\
\hline High & 700 & 100 & 0.58 & 1,330 \\
\hline Low & 370 & 70 & 0.22 & 930 \\
\hline
\end{tabular}

- $\quad$ Big George. The Big George coal seam, stratigraphically and depositionally similar to the Wyodak, exists in the western portion of Partition \#2.

- $\quad$ Area. The Big George coal seam meets study inclusion criteria in 2 townships.

- Coal Thickness. The Big George coal seam thickness averages 90 feet, with a range of 80 to 100 feet.

- Coal Depth. The depth to the top of the Big George seam averages 860 feet, with a range of 850 to 875 feet.

- Development. Approximately 300 Big George coal wells have been drilled or permitted in this partition.

- $\quad$ Time Zero Plot. The Big George coal wells in Partition \#2 have been combined into a composite Fort Union interval in the production data base. Thus, a distinct time zero plot for this coal seam is not available.

- $\quad$ Type Well. The history-matched Big George well in Partition \#3, adjusted for depth, gas content, and coal thickness, serves as the Big George type well for Partition \#2. Because the Big George coal exists in only two townships and has relatively uniform depth and thickness, only an average Big George well is used.

Table 6-4. Big George Coal Seam

\begin{tabular}{|l|c|c|c|c|}
\hline Type Well & $\begin{array}{c}\text { Well Depth } \\
\text { (ft) }\end{array}$ & $\begin{array}{c}\text { Coal Thickness } \\
\text { (ft) }\end{array}$ & $\begin{array}{c}\text { Cumulative Gas } \\
\text { Recovery } \\
\text { (Bcf) }\end{array}$ & $\begin{array}{c}\text { Cumulative } \\
\text { Water Recovery } \\
\text { (M bls) }\end{array}$ \\
\hline Average & 950 & 90 & 0.55 & 700 \\
\hline
\end{tabular}

- Cook. The Cook coal seam exists at sufficient thickness in the central portion of Partition \#2.

- $\quad$ Area. The Cook coal seam meets study inclusion criteria in two townships.

- Coal Thickness. The Cook coal seam thickness averages 30 feet. 
- Coal Depth. The depth to the top of the Cook seam averages 740 feet, with a range of 650 to 830 feet.

- Development. The Cook coal seam is undeveloped.

- $\quad$ Time Zero Plot. Not available.

- Type Well. The history-matched Cook well in Partition \#8, adjusted for depth, gas content, and coal thickness, serves as the Cook type well for Partition \#2. Because the Cook coal exists in only two townships with the same thickness, only an average Cook well is used.

Table 6-5. Cook Coal Seam

\begin{tabular}{|l|c|c|c|c|}
\hline Type Well & $\begin{array}{c}\text { Well Depth } \\
\text { (ft) }\end{array}$ & $\begin{array}{c}\text { Coal Thickness } \\
\text { (ft) }\end{array}$ & $\begin{array}{c}\text { Cumulative Gas } \\
\text { Recovery } \\
\text { (Bcf) }\end{array}$ & $\begin{array}{c}\text { Cumulative } \\
\text { Water Recovery } \\
\text { (M bls) }\end{array}$ \\
\hline Average & 770 & 30 & 0.21 & 200 \\
\hline
\end{tabular}

- Pawnee. The Pawnee seam exists at sufficient thickness in the southwestern portion of Partition \#2.

- $\quad$ Area. The Pawnee coal seam meets study inclusion criteria in 5 townships.

- Coal Thickness. The Pawnee coal seam thickness averages 22 feet with a range of 20 to 30 feet.

- Coal Depth. The depth to the top of the Pawnee seam averages 1,340 feet, with a range of 1,200 to 1,620 feet.

- Development. The Pawnee coal seam is undeveloped.

- $\quad$ Time Zero Plot. Not available.

- $\quad$ Type Well. The history-matched Pawnee well in Partition \#8, adjusted for depth, gas content, permeability, and coal thickness, serves as the Pawnee type well for Partition \#2. Because the Pawnee coal seam has relatively uniform depth and thickness, only an average well is used.

Table 6-6. Pawnee Coal Seam

\begin{tabular}{|l|c|c|c|c|}
\hline Type Well & $\begin{array}{c}\text { Well Depth } \\
\text { (ft) }\end{array}$ & $\begin{array}{c}\text { Coal Thickness } \\
\text { (ft) }\end{array}$ & $\begin{array}{c}\text { Cumulative Gas } \\
\text { Recovery } \\
\text { (Bcf) }\end{array}$ & $\begin{array}{c}\text { Cumulative } \\
\text { Water Recovery } \\
\text { (M bls) }\end{array}$ \\
\hline Average & 1,360 & 22 & 0.29 & 290 \\
\hline
\end{tabular}


Table 6-7. In-Place and Technically Recoverable CBM, Partitions \#1 and \#2

\begin{tabular}{|l||r|r|r|r||r|r|}
\hline Coal Seam & $\begin{array}{c}\text { No. Full } \\
\text { Townships }\end{array}$ & $\begin{array}{c}\text { Average } \\
\text { Depth } \\
\text { (ft) }\end{array}$ & $\begin{array}{c}\text { Average } \\
\text { Thickness } \\
\text { (ft) }\end{array}$ & $\begin{array}{c}\text { Average Gas } \\
\text { Content } \\
\text { (cf/ton) }\end{array}$ & $\begin{array}{c}\text { Gas in } \\
\text { Place } \\
\text { (Bcf) }\end{array}$ & $\begin{array}{c}\text { Technically } \\
\text { Recoverable } \\
\text { Resources } \\
\text { (Bcf) }\end{array}$ \\
\hline Anderson & 1 & 450 & 25 & 39 & 40 & 30 \\
\hline Canyon & 2 & 575 & 48 & 51 & 210 & 180 \\
\hline Wyodak & 5 & 440 & 86 & 42 & 760 & 560 \\
\hline Big George & 2 & 860 & 90 & 86 & 550 & 120 \\
\hline Cook & 2 & 740 & 30 & 65 & 150 & 420 \\
\hline Pawnee & 5 & 1,336 & 22 & 108 & 470 & 1,630 \\
\hline Totals & & & & & 2,170 & \\
\hline
\end{tabular}

${ }^{*}$ Top of coal

\subsection{Partitions \#3 and \#12}

\subsubsection{Summary}

The main features of Partitions \#3 and \#12, in the Powder River Basin, are as follows:

- Partition \#3 covers a 21-township area in the south-central portion of the PRB, from 40N to $44 \mathrm{~N}$ and from $73 \mathrm{~W}$ to $79 \mathrm{~W}$, Figure 6-5. Partition \#12 covers a 12-township area along the western edge of the PRB, Figure 6-6. Only one township (42N 77W) and only one coal seam, the Big George, meet the study inclusion criteria in Partition \#12. Because this township forms the western extent of the Big George coal seam in Partition \#3, this single township and coal seam in Partition \#12 is included in the data and discussion of the Big George coal seam in Partition \#3.

- The stratigraphic section contains the Anderson, Canyon, Wyodak, Big George, and Cook coal seams. (The Wyodak "fairway" boundary crosses the northeast corner of the partition.) The remainder of the area is included in the Big George "fairway" for coal seam designation purposes.

- $\quad$ The depth to the top of these coals ranges from 730 to 1,500 feet, with individual coal seam thickness ranging from 30 to 130 feet (township level averages).

- The gas in place in the partition is $8.3 \mathrm{Tcf}$, with technically recoverable gas of 4,060 Bcf. The results by coal seam are provided in Table 6-12.

\subsubsection{Discussion of Major Seams}

- Anderson. The Anderson exists as a distinct seam on the eastern portion of the partition.

- $\quad$ Area. The Anderson coal seam meets study inclusion criteria in one township. 


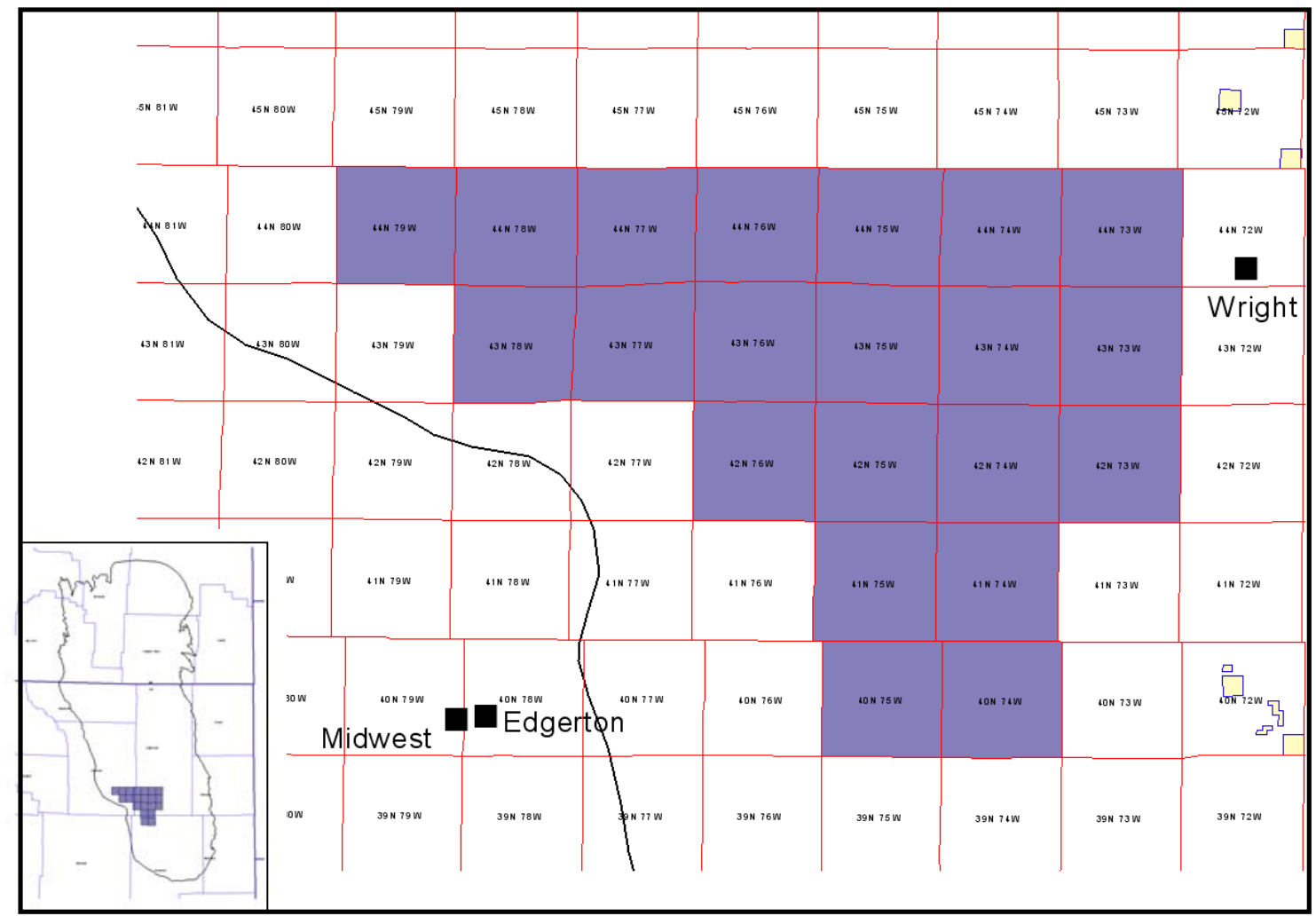

Figure 6-5. Partition \#3 Base Map 


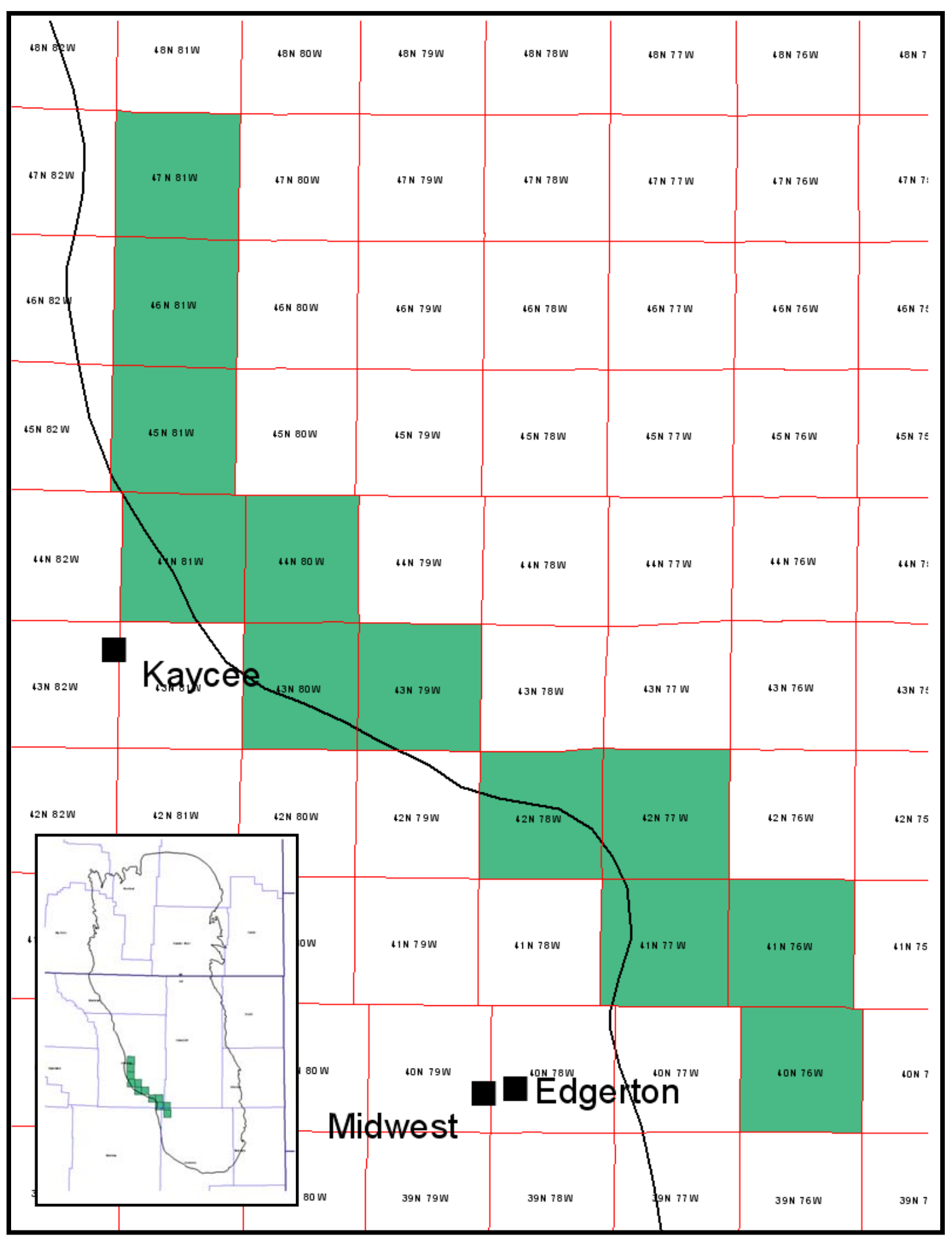

Figure 6-6. Partition \#12 Base Map 
- Coal Thickness. The Anderson seam coal thickness averages 55 feet.

- Coal Depth. The depth of the Anderson seam averages 855 feet to top of coal.

- Development. Anderson coal seam development is just starting.

- $\quad$ Time Zero Plot. Not available.

- $\quad$ Type Well. The history-matched Anderson well in Partition \#4, adjusted for depth, gas content and coal thickness, serves as the Anderson type well for Partition \#3. Since only one township contains Anderson coal of sufficient depth and thickness, only an average well is used.

Table 6-8. Anderson Coal Seam

\begin{tabular}{|l|c|c|c|c|}
\hline Type Well & $\begin{array}{c}\text { Well Depth } \\
\text { (ft) }\end{array}$ & $\begin{array}{c}\text { Coal Thickness } \\
\text { (ft) }\end{array}$ & $\begin{array}{c}\text { Cumulative Gas } \\
\text { Recovery } \\
\text { (Bcf) }\end{array}$ & $\begin{array}{c}\text { Cumulative } \\
\text { Water Recovery } \\
\text { (M bls) }\end{array}$ \\
\hline Average & 855 & 55 & 0.40 & 270 \\
\hline
\end{tabular}

- Canyon. The Canyon exists as a distinct seam primarily in the eastern and central portions of Partition \#3. The Canyon is sometimes included within or called the Wyodak.

- $\quad$ Area. The Canyon coal seam meets study inclusion criteria in 9 townships located in the western portion of the partition.

- Coal Thickness. The Canyon coal seam thickness averages 43 feet, with a range of 25 to 65 feet.

- Coal Depth. The depth to the top of the Canyon seam averages 970 feet, with a range of 730 to 1,425 feet.

- Development. Canyon coal seam development is just starting and is concentrated in township $44 \mathrm{~N} 74 \mathrm{~W}$.

- $\quad$ Time Zero Plot. Not available.

- $\quad$ Type Well. The history-matched Canyon well in Partition \#4, adjusted for depth, gas content and coal thickness, serves as the Canyon type well for Partition \#3. 
Table 6-9. Canyon Coal Seam

\begin{tabular}{|l|c|c|c|c|}
\hline \multicolumn{1}{|c|}{ Type Well } & $\begin{array}{c}\text { Well Depth } \\
\text { (ft) }\end{array}$ & $\begin{array}{c}\text { Coal Thickness } \\
\text { (ft) }\end{array}$ & $\begin{array}{c}\text { Cumulative Gas } \\
\text { Recovery } \\
\text { (Bcf) }\end{array}$ & $\begin{array}{c}\text { Cumulative } \\
\text { Water Recovery } \\
\text { (M bls) }\end{array}$ \\
\hline Average & 1,013 & 43 & 0.33 & 330 \\
\hline High & 960 & 60 & 0.43 & 460 \\
\hline Low & 830 & 30 & 0.25 & 230 \\
\hline
\end{tabular}

- Big George. The Big George coal seam, stratigraphically and depositionally similar to the Wyodak, exists in the central portion of Partition \#3 and in Partition \#12.

- $\quad$ Area. The Big George coal seam meets study inclusion criteria in 11 townships, including one township in Partition \#12.

- Coal Thickness. The Big George seam coal thickness averages 100 feet, with a range of 70 to 125 feet.

- Coal Depth. The depth to the top of the Big George seam averages 1,280 feet, with a range of 970 to 1,500 feet.

- Development. Over 300 Big George coal wells have been drilled or permitted in this partition.

- $\quad$ Time Zero Plot. The time zero plot for 38 producing Big George wells in T43-44N, R74W is provided in Figure 6-7.

- $\quad$ Type Well. The history-matched Big George well shown in Figure 6-8, adjusted for depth, gas content and coal thickness, serves as the Big George type well for Partition \#3.

Table 6-10. Big George Coal Seam

\begin{tabular}{|l|c|c|c|c|}
\hline \multicolumn{1}{|c|}{ Type Well } & $\begin{array}{c}\text { Well Depth } \\
\text { (ft) }\end{array}$ & $\begin{array}{c}\text { Coal Thickness } \\
\text { (ft) }\end{array}$ & $\begin{array}{c}\text { Cumulative Gas } \\
\text { Recovery } \\
\text { (Bcf) }\end{array}$ & $\begin{array}{c}\text { Cumulative } \\
\text { Water Recovery } \\
\text { (M bls) }\end{array}$ \\
\hline Average & 1,380 & 100 & 0.66 & 770 \\
\hline High & 1,525 & 125 & 0.89 & 970 \\
\hline Low & 1,420 & 70 & 0.48 & 540 \\
\hline
\end{tabular}

- Cook. The Cook coal seam exists at sufficient thickness in the eastern portion of Partition \#3.

- $\quad$ Area. The Cook coal seam meets study inclusion criteria in two townships.

- Coal Thickness. The Cook coal seam thickness averages 30 feet. 


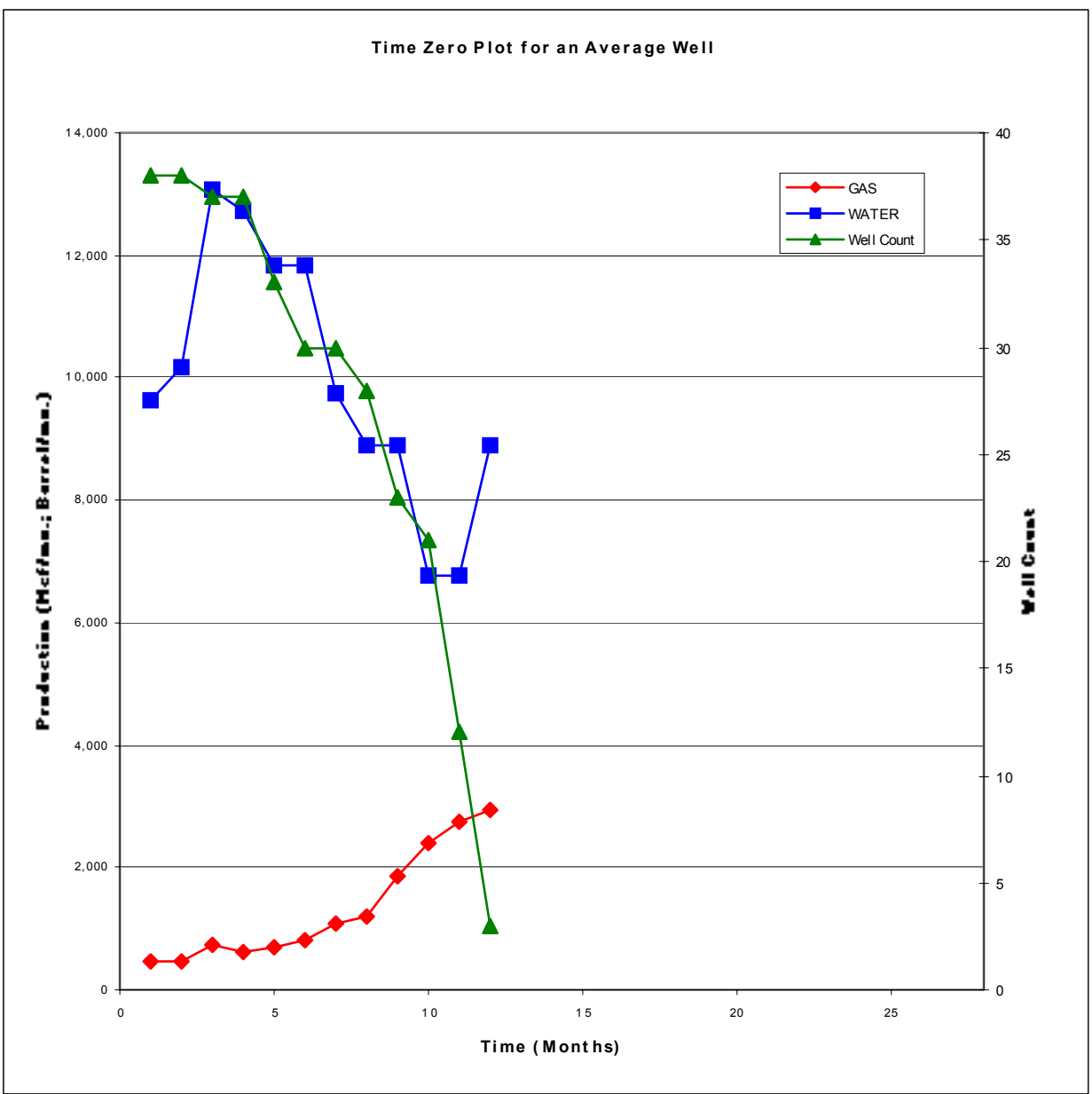

Figure 6-7. Big George Time Zero Plot 


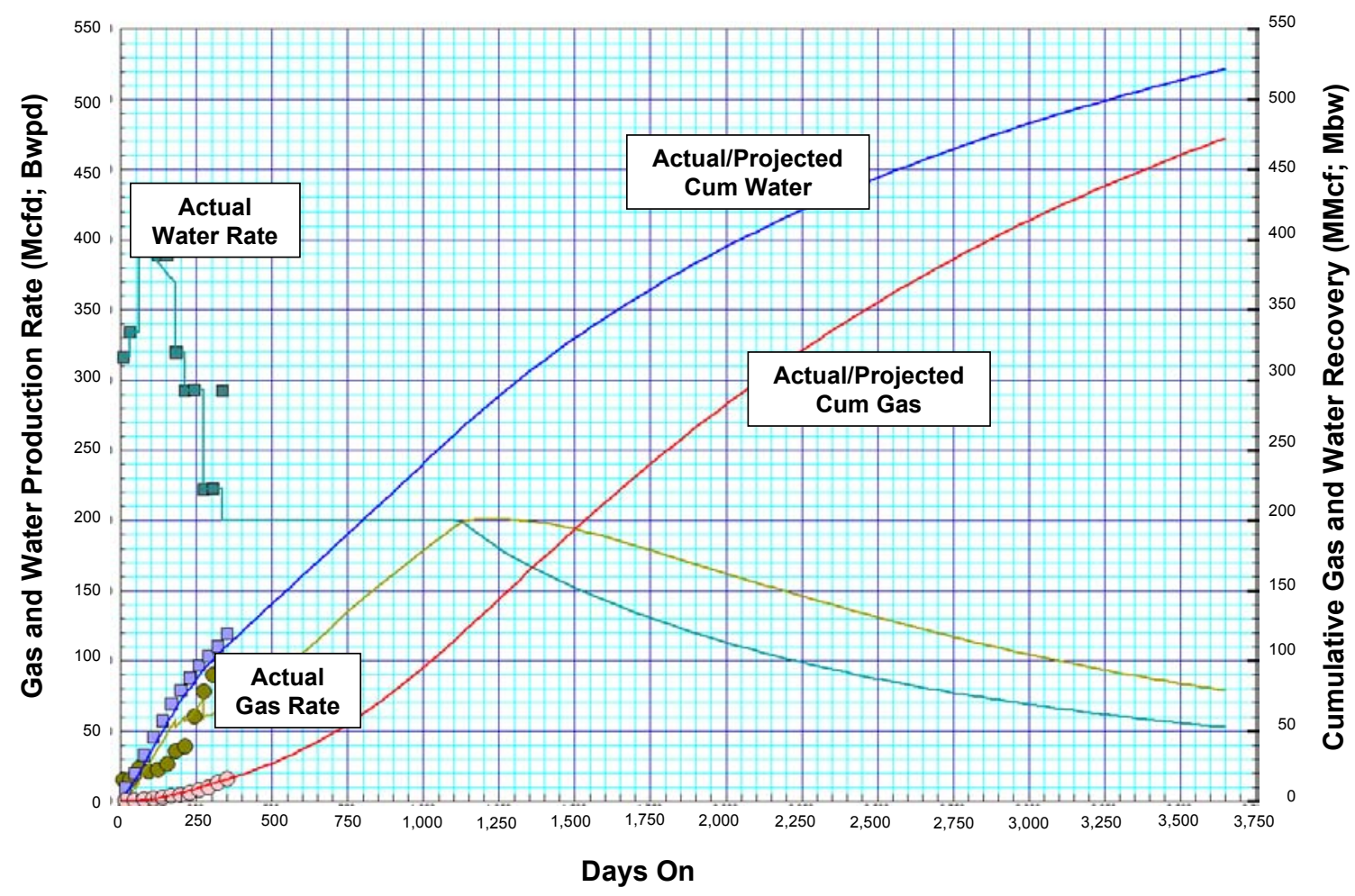

Figure 6-8. Big George Partition \#3 
- Coal Depth. The depth to the top of the Cook seam averages 1,030 feet, with a range of 930 to 1,125 feet.

- Development. The Cook coal seam is essentially undeveloped.

- $\quad$ Time Zero Plot. Not available.

- Type Well. The history-matched Cook well in Partition \#8, adjusted for depth, gas content, and coal thickness, serves as the Cook type well for Partition \#3. Because the Cook coal exists in only two townships with the same coal thickness, only an average Cook well is used in Partition \#3.

Table 6-11. Cook Coal Seam

\begin{tabular}{|l|c|c|c|c|}
\hline Type Well & $\begin{array}{c}\text { Well Depth } \\
\text { (ft) }\end{array}$ & $\begin{array}{c}\text { Coal Thickness } \\
\text { (ft) }\end{array}$ & $\begin{array}{c}\text { Cumulative Gas } \\
\text { Recovery } \\
\text { (Bcf) }\end{array}$ & $\begin{array}{c}\text { Cumulative } \\
\text { Water Recovery } \\
\text { (M bls) }\end{array}$ \\
\hline Average & 1,060 & 30 & 0.29 & 200 \\
\hline
\end{tabular}

Table 6-12. In-Place and Technically Recoverable CBM, Partitions \#3 and \#12

\begin{tabular}{|l||r|r|r|r||r|r|}
\hline Coal Seam & $\begin{array}{c}\text { No. } \\
\text { Full } \\
\text { Townships }\end{array}$ & $\begin{array}{c}\text { Average } \\
\text { Depth } \\
\text { (ft) }\end{array}$ & $\begin{array}{c}\text { Average } \\
\text { Thickness } \\
\text { (ft) }\end{array}$ & $\begin{array}{c}\text { Average Gas } \\
\text { Content } \\
\text { (cf/ton) }\end{array}$ & $\begin{array}{l}\text { Gas in } \\
\text { Place } \\
\text { (Bcf) }\end{array}$ & $\begin{array}{c}\text { Technically } \\
\text { Recoverable } \\
\text { Resources } \\
\text { (Bcf) }\end{array}$ \\
\hline Anderson & 1 & 800 & 55 & 70 & 160 & 110 \\
\hline Canyon & 9 & 970 & 43 & 81 & 1,260 & 870 \\
\hline Big George & 11 & 1,280 & 100 & 107 & 6,620 & 2,910 \\
\hline Cook & 2 & 1,030 & 30 & 86 & 210 & 170 \\
\hline Totals & & & & & 8,250 & 4,060 \\
\hline
\end{tabular}

${ }^{*}$ Top of coal

\subsection{Partition \#4}

\subsubsection{Summary}

The main features of Partition \#4, in the east-central portion of the Powder River Basin, are as follows:

- The partition covers a 22-township area on the eastern edge of the PRB, from $45 \mathrm{~N}$ to $52 \mathrm{~N}$ and from $70 \mathrm{~W}$ to $73 \mathrm{~W}$, Figure 6-9.

- A series of coal mines exists in the townships along the shallower eastern edge; as a result, the bulk of CBM development is in the eight townships along the western edge of 


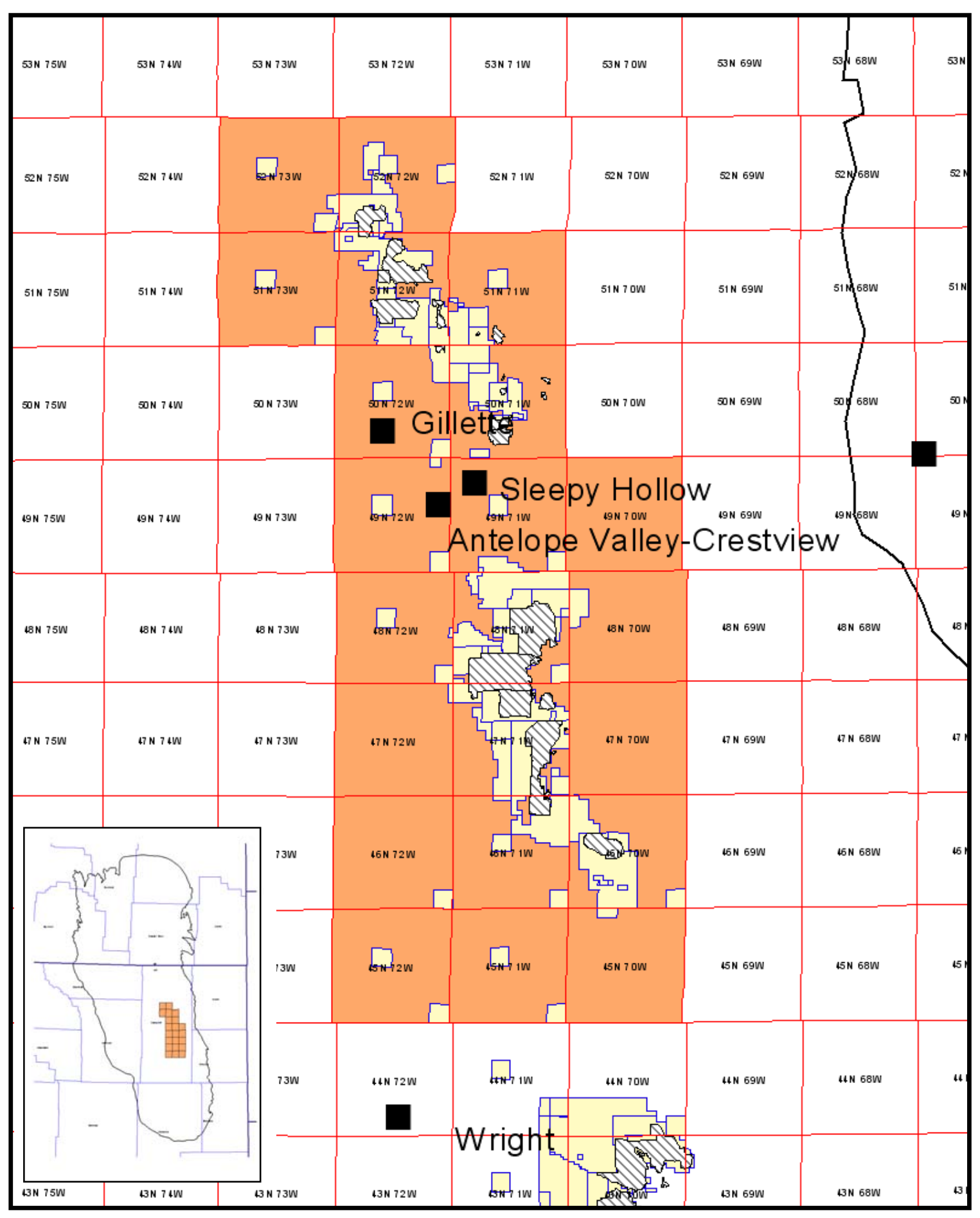

Figure 6-9. Partition \#4 Base Map 
this partition. The partition contains some of the earliest CBM wells and "fields" in the PBR, such as Caballo and Bonepile.

- Partition \#4 contains 7 major coal seams in the Fort Union Formation. The depth to these coals ranges from 450 to 1,500 feet, with coal seam thickness ranging from 23 to 73 feet (township level averages). The gas in place in the partition is $4.2 \mathrm{Tcf}$, with technically recoverable gas of 3,540 Bcf. The results, by coal seam, are provided in Table 6-20.

- The stratigraphic sequence for some of the major coal seams in this partition, such as the Anderson, Canyon and Cook, is shown in Figure 6-10, a sample log from Sec. 3, 53N, $74 \mathrm{~W}$. The log identifies coals that meet the study criteria for selection in that township (depth greater than 300 feet and thickness greater than 20 feet. In addition, a series of thinner coals, with thickness of 10 to 20 feet, exist in this partition, such as the Smith and Swartz.

\subsubsection{Geologic Background}

Partition \#4 is located along the eastern rim of the Powder River Coal Basin in an area of Fort Union Formation outcrops. Structural strike is NW/SE with a southwestern dip of 1.5 degrees. Subtle structural nosing and low relief normal faulting locally interrupt the gentile southwest dip.

Stratigraphically, the coal seams in Partition \#4 exist in two groups - an upper group consisting of the Smith, Swartz, Anderson, Canyon, Wyodak, and Cook seams, and a lower group consisting of the Wall, Pawnee and the Cache seams. These groups are recognizable by their depth, stratigraphic proximity and thickness.

The upper group, a thick succession of coals separated by thin "parts" and "splits," is characterized by shallow depth (450 to 790 feet) and considerable coal thickness (30 to 70 feet). Correlation challenges exist due to stratigraphic proximity and apparent stratigraphic overlap due to averaging data over an entire township. (Some Powder River CBM geologist include all upper groups of coals within the Wyodak.)

The lower group is characterized by deeper depth $(1,020$ to 1,500$)$, lower coal thickness (20 to 30 feet), and considerable stratigraphic separation (200 to 300) feet between coal seams.

CBM operators have extensively developed this partition, with the great majority of the wells in the Wyodak seam and/or its stratigraphic equivalents, the Anderson and Canyon seams, that are often called the Fort Union.

\subsubsection{Discussion of Major Seams}

- Anderson. The first major coal seam in Partition \#4 is the Anderson, often included in the Wyodak seam interval. The stratigraphic proximity of the Anderson to the adjacent Canyon, Smith and Swartz seams provides correlation challenges. (This can lead to correlation problems especially in the eastern portion of the partition where the Fort Union Formation thins dramatically.) 


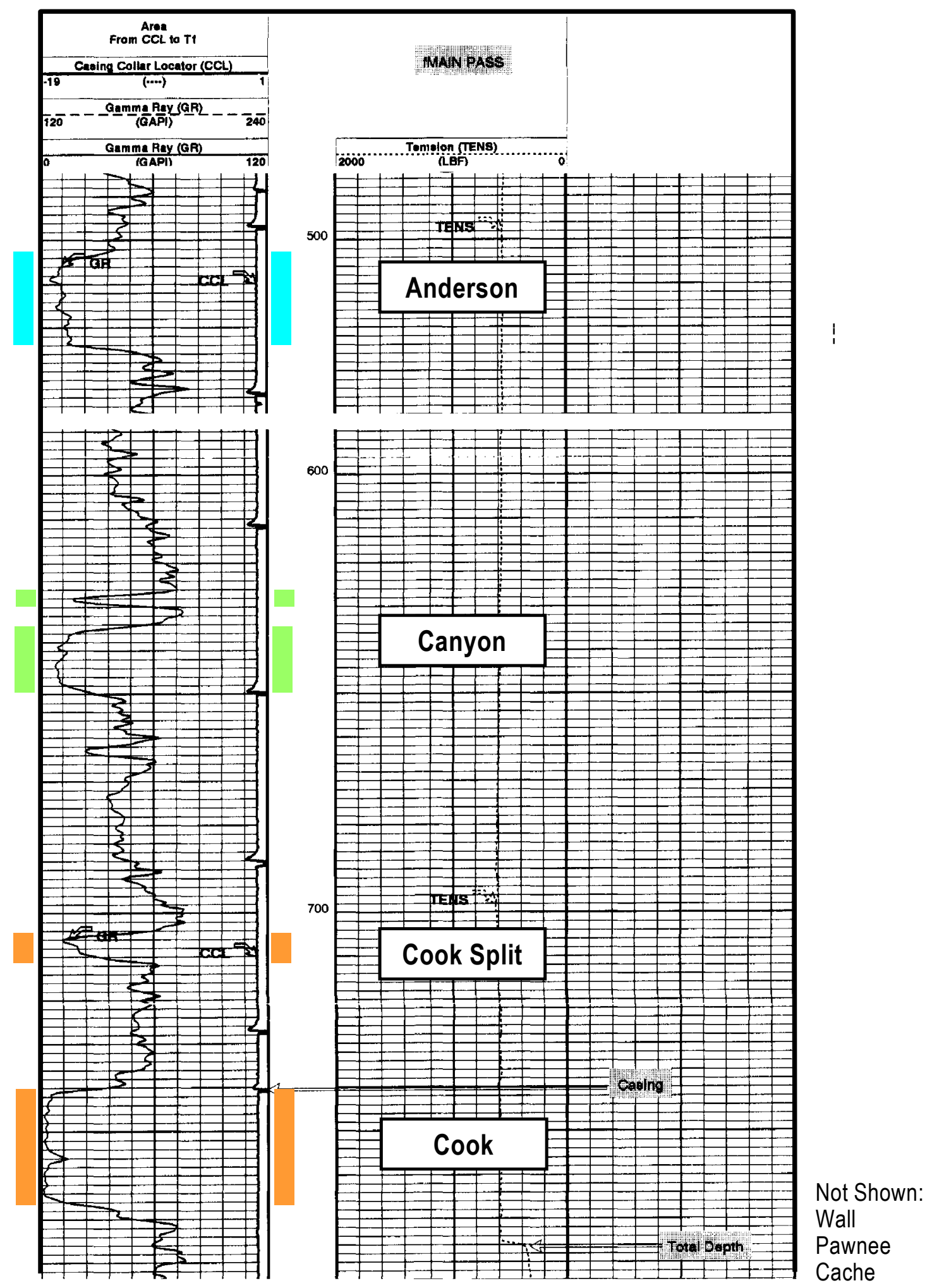

Figure 6-10. Partition \#4 Sample Log 
- $\quad$ Area. The Anderson coal seam meets study inclusion criteria in 6 townships located in the western and central portions of the partition.

- Coal Thickness. The Anderson seam coal thickness averages 30 feet, with a range of 20 to 50 feet.

- Coal Depth. The depth to the top of the Anderson seam averages 450 feet, with a range of 300 to 650 feet.

- Development. Figure 6-11 provides the location of the currently drilled Anderson CBM wells.

- $\quad$ Time Zero Plot. The time zero plot for 89 producing Anderson coal seam wells in $\mathrm{T} 51 \mathrm{~N}, \mathrm{R} 73 \mathrm{~W}$ is provided in Figure 6-12. After initial rates of 150 barrels of water per day, the water rates decline to about 60 barrels per day at the end of year 1. Gas production starts and peaks early at about 100 Mcfd indicating the presence of free gas.

- $\quad$ Type Well. The history-matched type well for the Anderson coal seam is provided in Figure 6-13. After normalizing for coal thickness, depth and gas content, the estimated gas and water recoveries are as follows:

Table 6-13. Anderson Coal Seam

\begin{tabular}{|l|c|c|c|c|}
\hline \multicolumn{1}{|c|}{ Type Well } & $\begin{array}{c}\text { Well Depth } \\
\text { (ft) }\end{array}$ & $\begin{array}{c}\text { Coal Thickness } \\
\text { (ft) }\end{array}$ & $\begin{array}{c}\text { Cumulative Gas } \\
\text { Recovery } \\
\text { (Bcf) }\end{array}$ & $\begin{array}{c}\text { Cumulative } \\
\text { Water Recovery } \\
\text { (M bls) }\end{array}$ \\
\hline Average & 480 & 30 & 0.12 & 150 \\
\hline High & 700 & 50 & 0.29 & 240 \\
\hline Low & 470 & 20 & 0.08 & 100 \\
\hline
\end{tabular}

- Canyon. The Canyon seam is stratigraphically below the Anderson and is also often included within the Wyodak seam. Like the Anderson, the Canyon presents correlation problems in the western portion of the study area due the proximity of adjacent coal seams.

- $\quad$ Area. The Canyon coal seam meets study inclusion criteria in 12 townships located in the western and central portion of the partition.

- Coal Thickness. The Canyon coal seam thickness averages 35 feet, with a range of 25 to 50 feet.

- Coal Depth. The depth to the top of the Canyon seam averages 540 feet, with a range of 300 to 800 feet. 


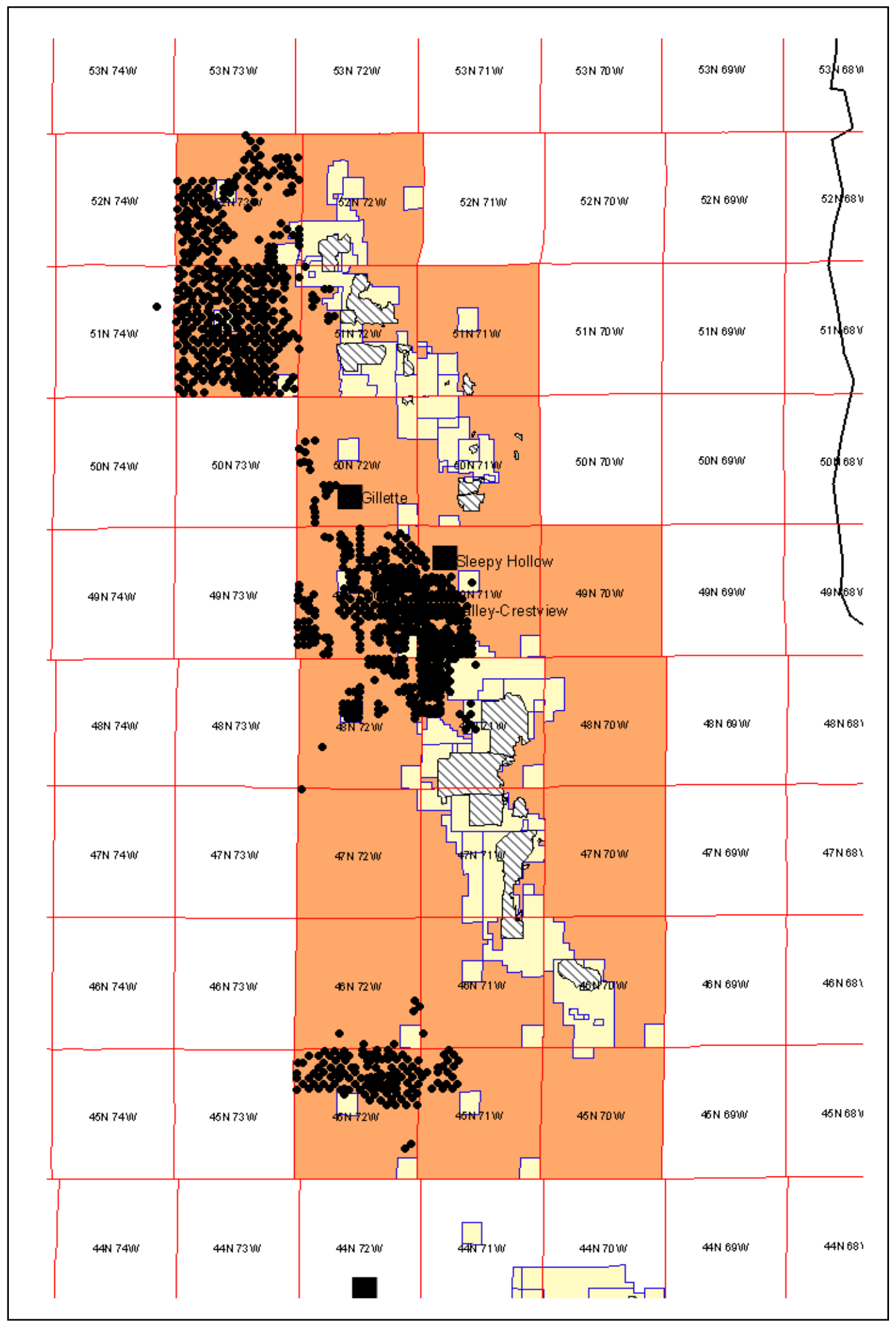

Figure 6-11. Partition \#4 Anderson Wells 


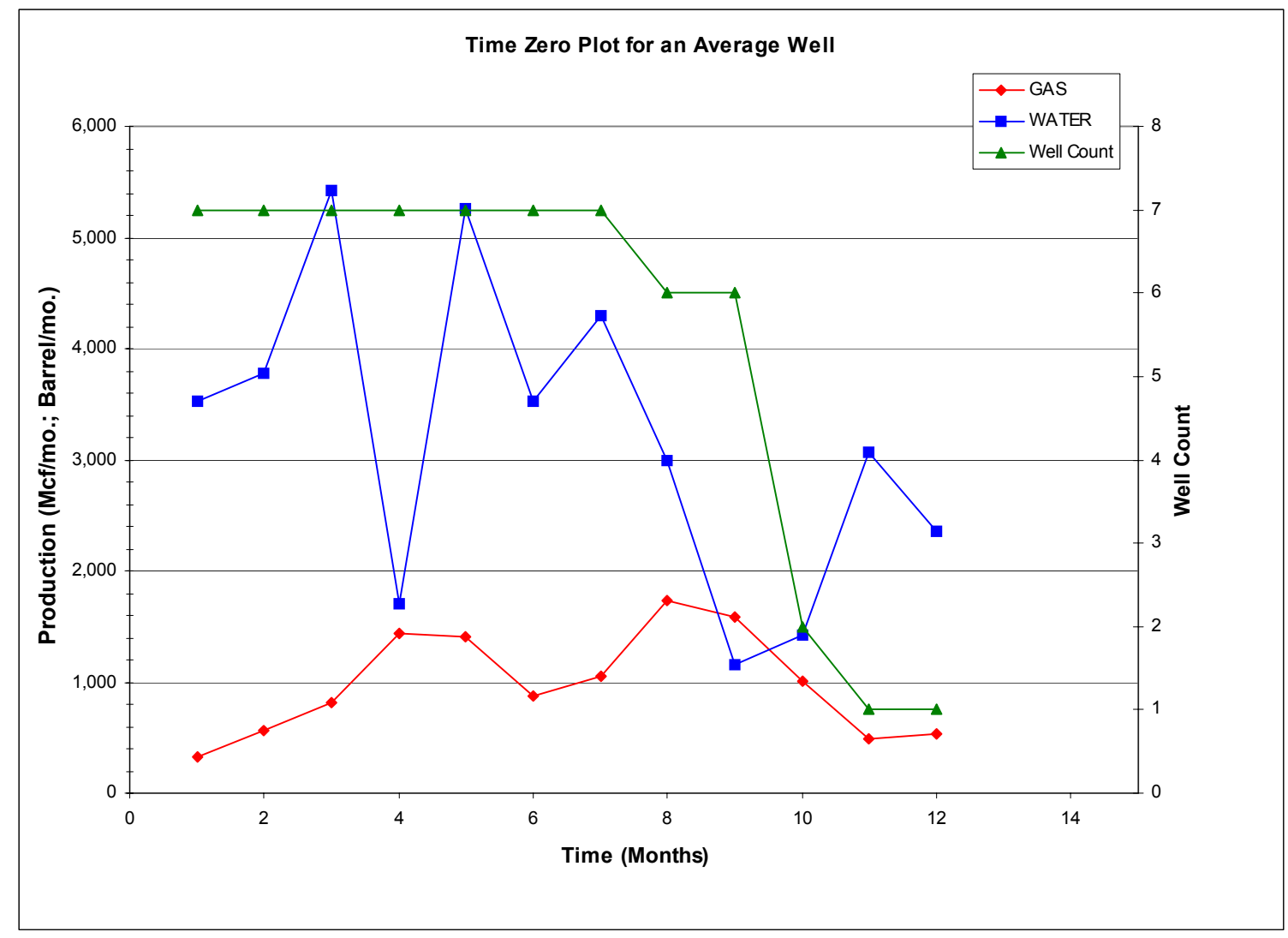

Figure 6-12. Canyon Time Zero Plot 


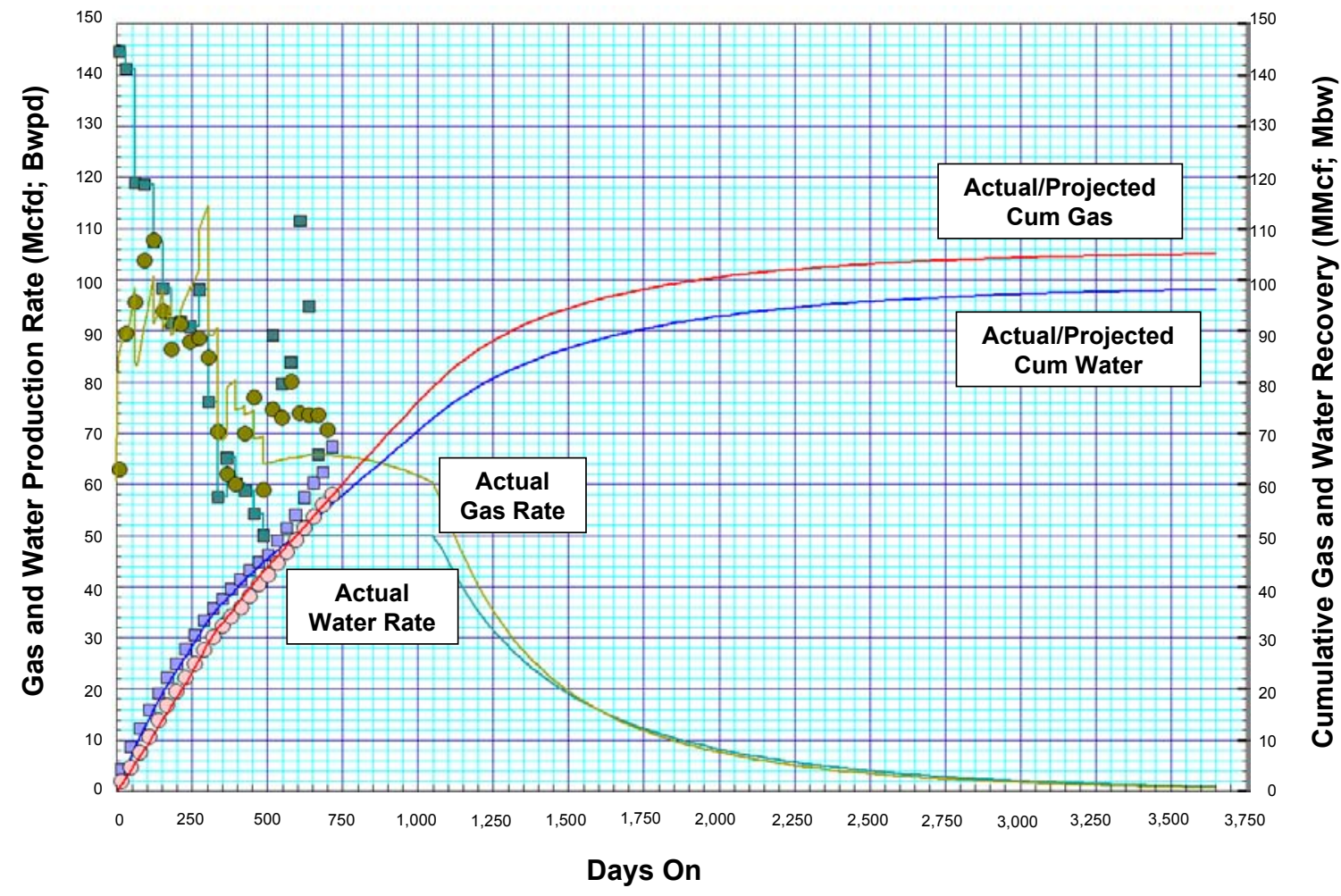

Figure 6-13. Anderson Type Well, Partition \#4 
- Development. Figure 6-14 provides the location of the currently drilled Canyon CBM wells.

- $\quad$ Time Zero Plot. The time zero plot for 173 producing Canyon coal seam wells in T51-52N, R73W is provided in Figure 6-15. Initial water rates are 300 or more barrels producing for the first year, declining to about 50 barrels per day at the end of year 3. Gas production starts early and peaks at nearly 300 Mcfd during year 1, indicating the presence of free gas.

- $\quad$ Type Well. The history-matched type well for Canyon coal seam is provided in Figure 6-16. After normalizing for coal thickness, depth and gas content, the estimated gas and water recoveries are as follows below.

Table 6-14. Canyon Coal Seam

\begin{tabular}{|l|c|c|c|c|}
\hline \multicolumn{1}{|c|}{ Type Well } & $\begin{array}{c}\text { Well Depth } \\
\text { (ft) }\end{array}$ & $\begin{array}{c}\text { Coal Thickness } \\
\text { (ft) }\end{array}$ & $\begin{array}{c}\text { Cumulative Gas } \\
\text { Recovery } \\
\text { (Bcf) }\end{array}$ & $\begin{array}{c}\text { Cumulative } \\
\text { Water Recovery } \\
\text { (M bls) }\end{array}$ \\
\hline Average & 575 & 35 & 0.20 & 270 \\
\hline High & 700 & 50 & 0.35 & 380 \\
\hline Low & 550 & 25 & 0.14 & 190 \\
\hline
\end{tabular}

- Wyodak. The Wyodak seam is the stratigraphic equivalent of the combined Anderson and Canyon seams. As such, separating the Anderson and Canyon from the Wyodak is often arbitrary.

- $\quad$ Area. The Wyodak coal seam meets study inclusion criteria in 6 townships located in the western portion of the partition.

- Coal Thickness. The Wyodak seam coal thickness averages 73 feet, with a range of 70 to 80 feet.

- Coal Depth. The depth to the top of the Wyodak seam averages 600 feet, with a depth range of 330 to 750 feet.

- Development. Figure 6-17 provides the locations of the currently drilled Wyodak CBM wells.

- $\quad$ Time Zero Plot. The time zero plot for 164 producing Wyodak coal seam wells in T47-48N, R72W is provided in Figure 6-18. Initial water rates are at 600 barrels per day, declining to about 400 barrels per day at the end of year 1 and to about 130 barrels per day at the end of year 4 . Gas production increases steadily, reaching 300 Mcfd during year 1 . After a 12-month plateau, gas production declines to about $150 \mathrm{Mcfd}$ at the end of year 2 and to about $80 \mathrm{Mcf}$ at the end of year 4. 


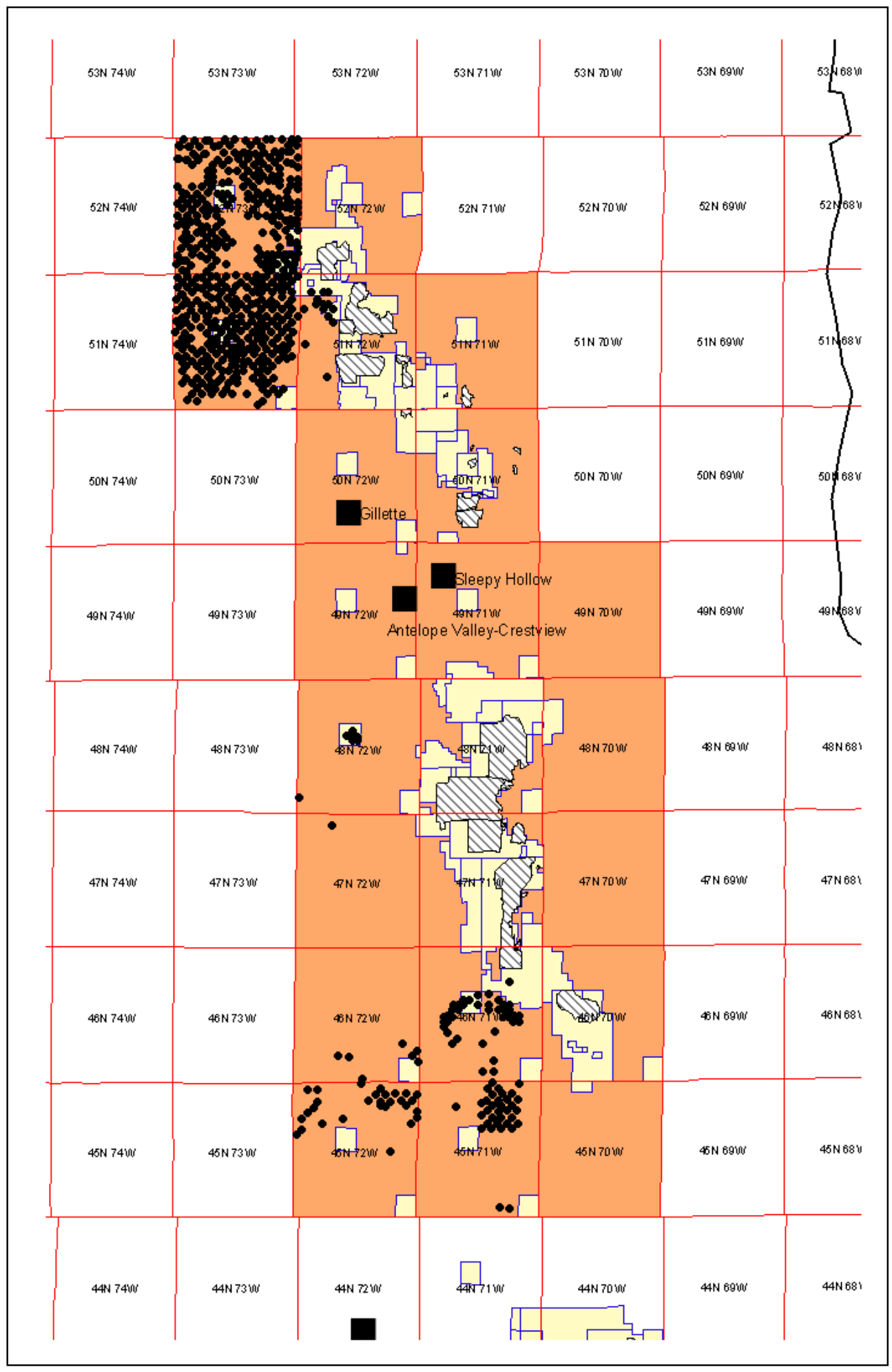

Figure 6-14. Partition \#4 Canyon Wells 


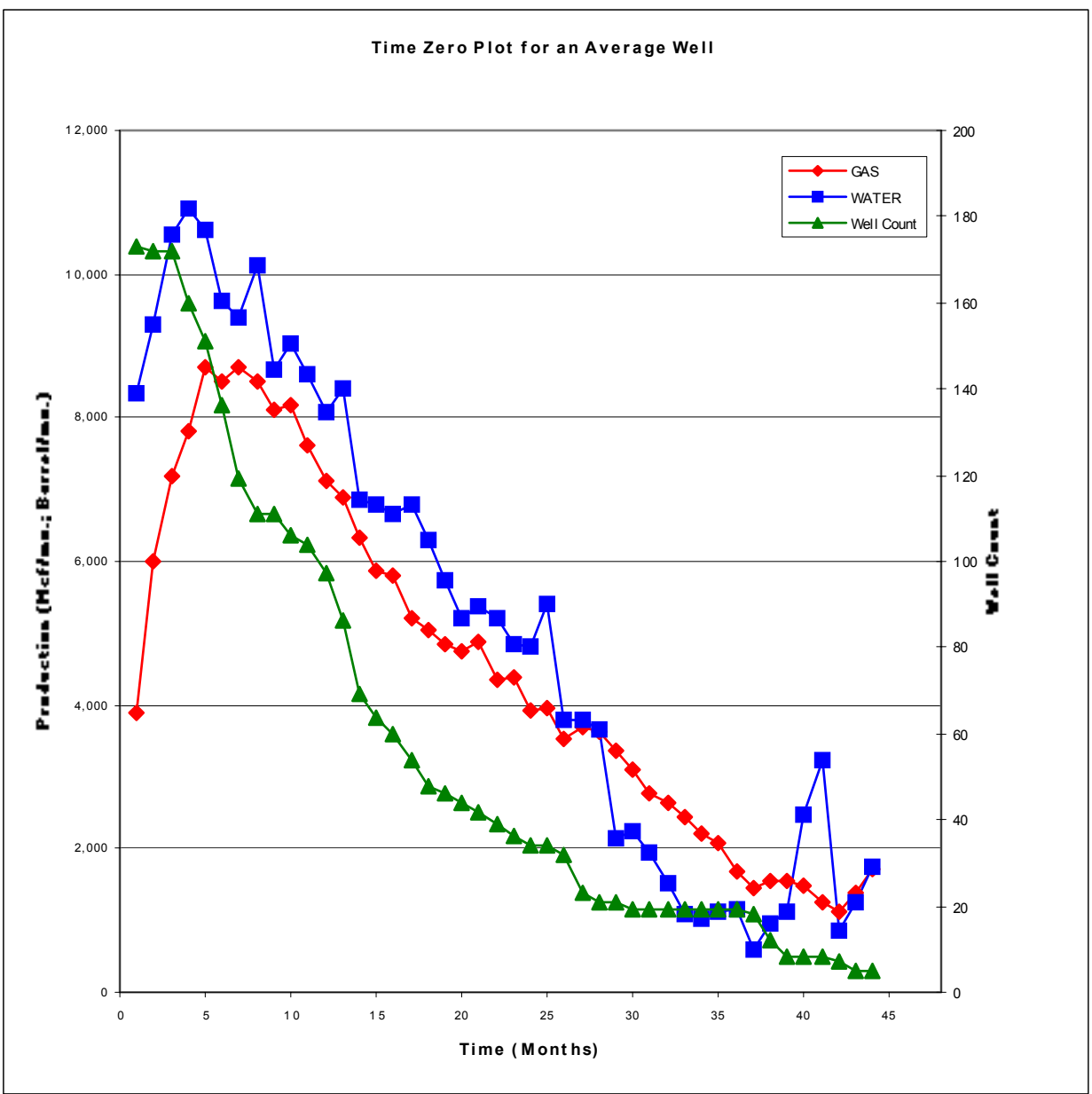

Figure 6-15. Canyon Time Zero Plot 


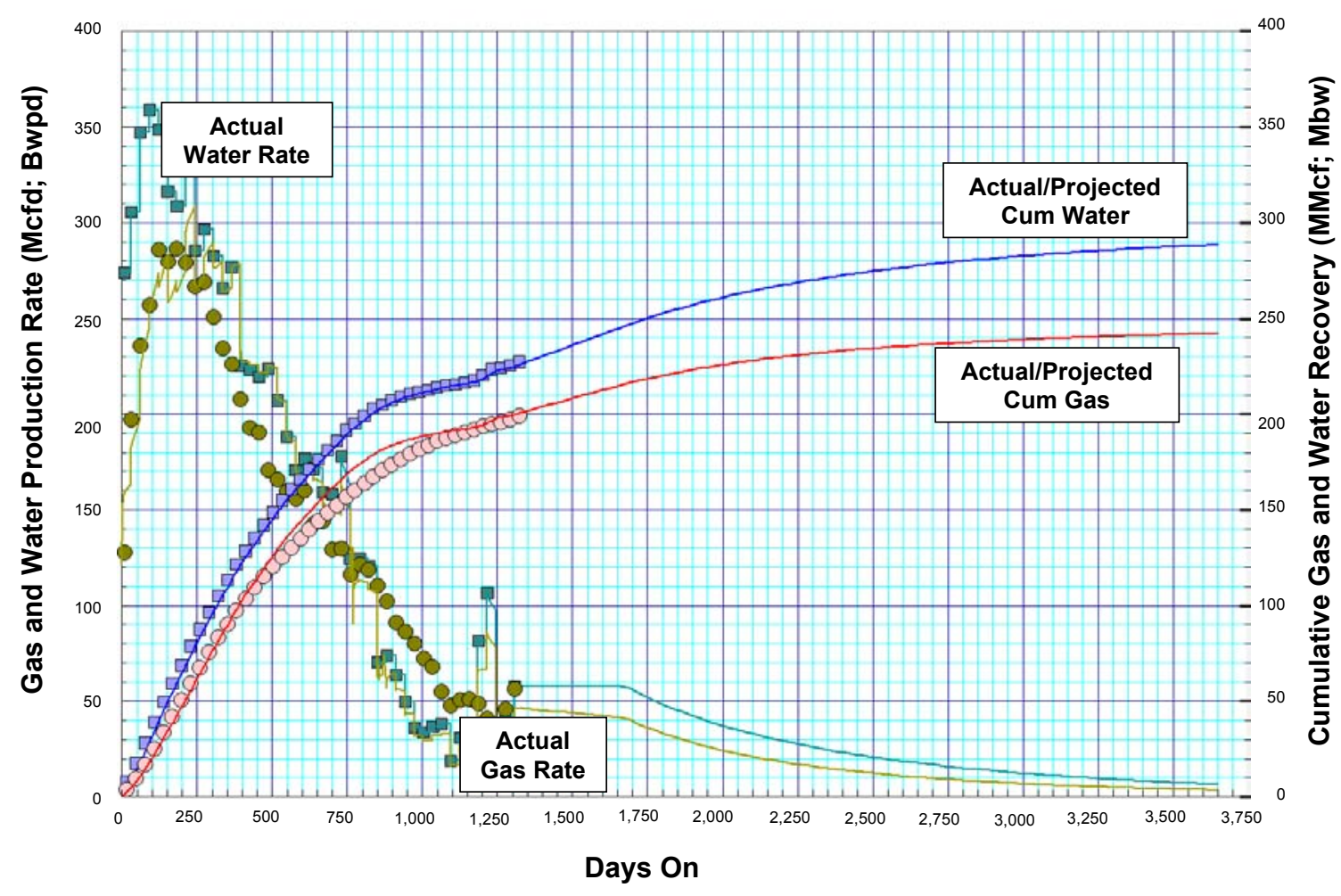

Figure 6-16. Canyon Type Well, Partition \#4 


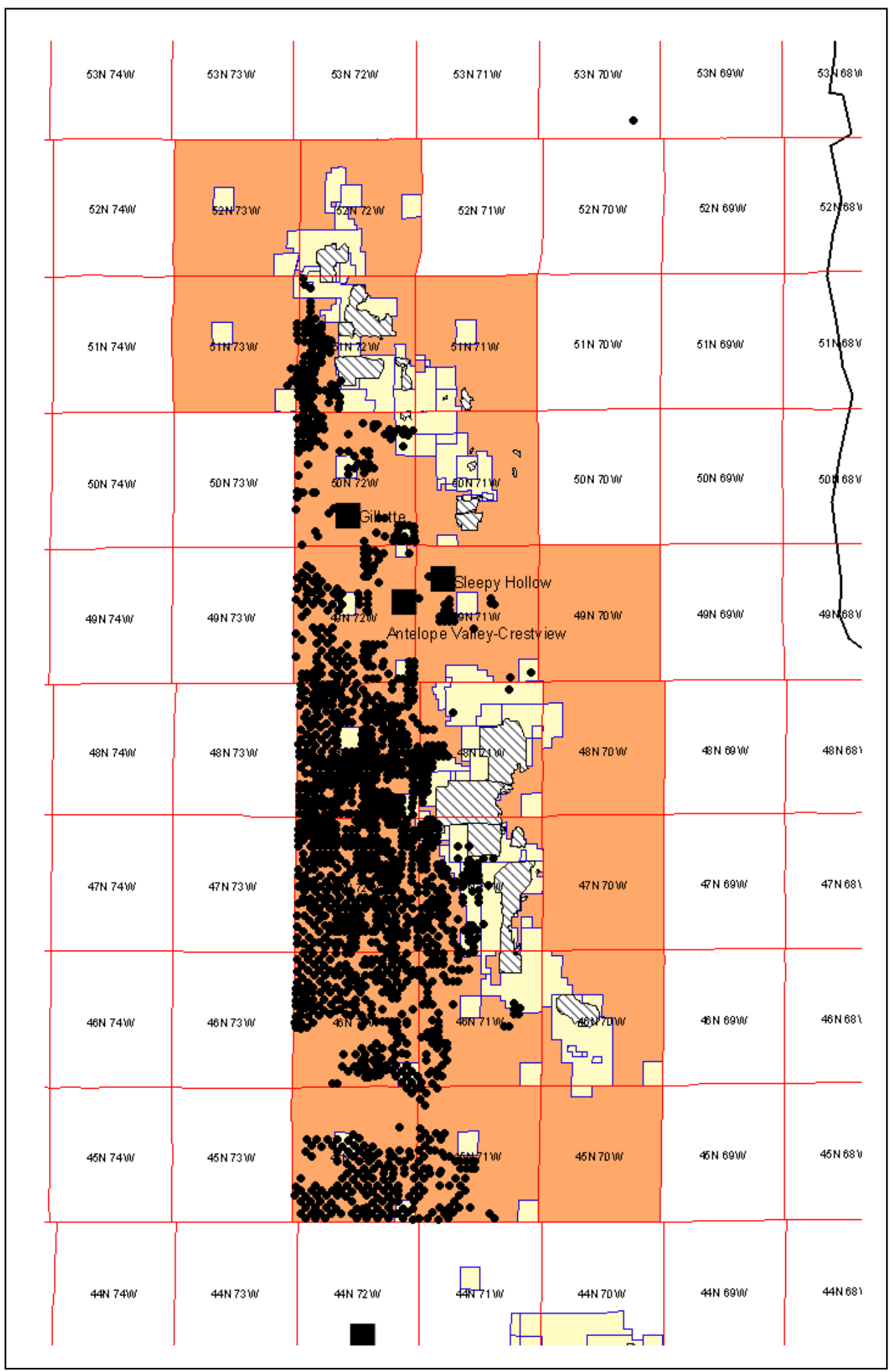

Figure 6-17. Partition \#4 Wyodak Wells 


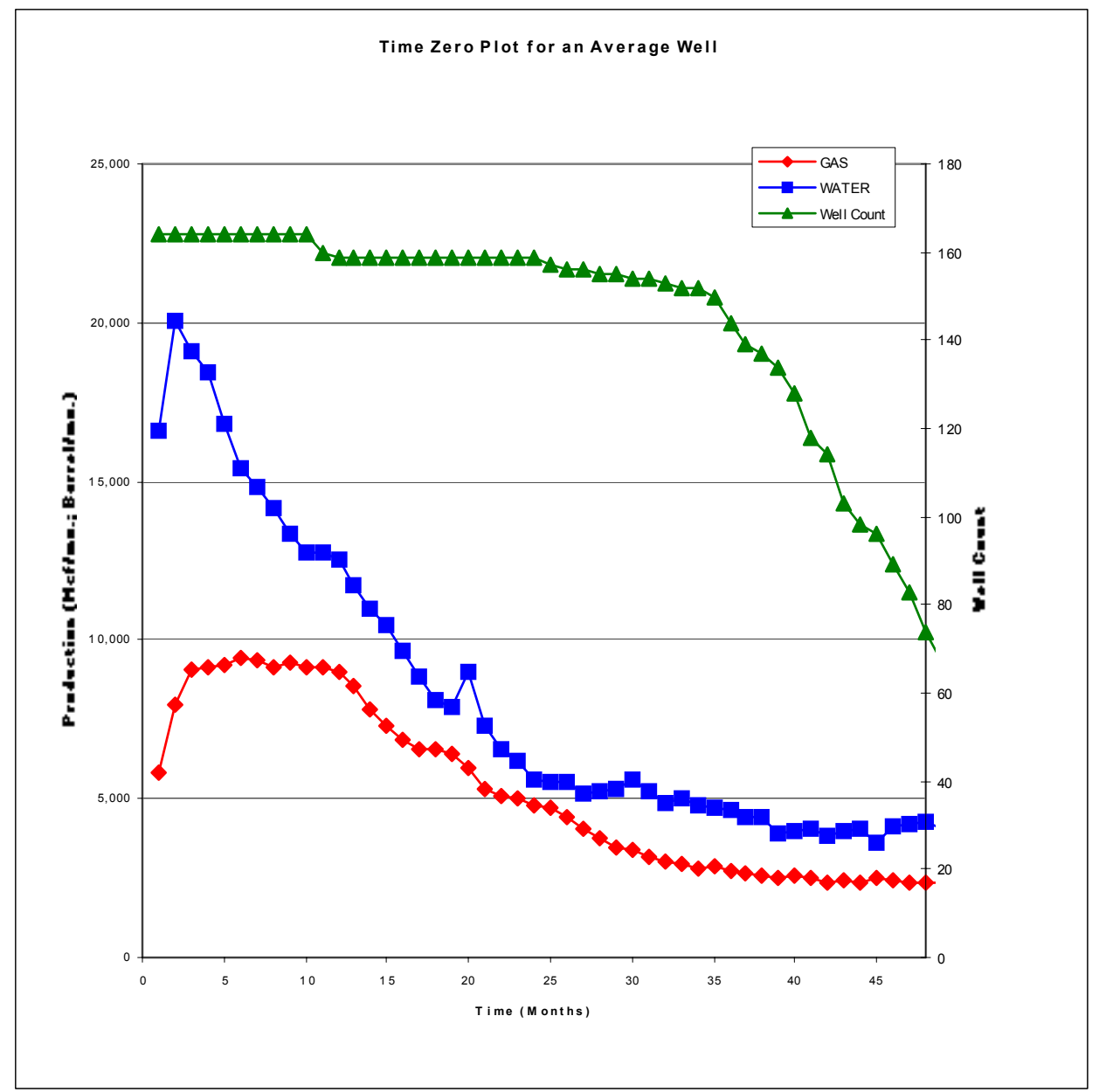

Figure 6-18. Wyodak Time Zero Plot 
- $\quad$ Type Well. The history-matched type well for the Wyodak coal seam is provided in Figure 6-19. After normalizing for coal thickness, depth and gas content, the estimated gas and water recoveries are as follows:

Table 6-15. Wyodak Coal Seam

\begin{tabular}{|l|c|c|c|c|}
\hline \multicolumn{1}{|c|}{ Type Well } & $\begin{array}{c}\text { Well Depth } \\
\text { (ft) }\end{array}$ & $\begin{array}{c}\text { Coal Thickness } \\
\text { (ft) }\end{array}$ & $\begin{array}{c}\text { Cumulative Gas } \\
\text { Recovery } \\
\text { (Bcf) }\end{array}$ & $\begin{array}{c}\text { Cumulative } \\
\text { Water Recovery } \\
\text { (M bls) }\end{array}$ \\
\hline Average & 670 & 73 & 0.48 & 960 \\
\hline High & 760 & 80 & 0.58 & 1,060 \\
\hline Low & 400 & 70 & 0.28 & 930 \\
\hline
\end{tabular}

- Cook. The Cook seam defines the base of the upper group of Fort Union coals in Partition \#4. The Cook seam is stratigraphically below the Canyon and Wyodak equivalents. The proximity of the Cook seam to the basal boundary of the Wyodak and equivalents poses correlation problems throughout the partition.

- $\quad$ Area. The Cook coal seam meets study inclusion criteria in 5 townships in the western portion of the partition.

- Coal Thickness. The Cook seam coal thickness averages 31 feet, with a range of 20 to 50 feet.

- $\quad$ Coal Depth. The depth to the top of the Cook seam averages 790 feet, with a depth range of 600 to 930 feet.

- Development. The drilled Cook CBM wells are shown in Figure 6-20.

- $\quad$ Time Zero Well. Not available.

- $\quad$ Type Well. The history-matched Cook well in Partition \#8, adjusted for depth, gas content, permeability and coal thickness, serves as the Cook type well for Partition \#4.

Table 6-16. Cook Coal Seam

\begin{tabular}{|l|c|c|c|c|}
\hline \multicolumn{1}{|c|}{ Type Well } & $\begin{array}{c}\text { Well Depth } \\
\text { (ft) }\end{array}$ & $\begin{array}{c}\text { Coal Thickness } \\
\text { (ft) }\end{array}$ & $\begin{array}{c}\text { Cumulative Gas } \\
\text { Recovery } \\
\text { (Bcf) }\end{array}$ & $\begin{array}{c}\text { Cumulative } \\
\text { Water Recovery } \\
\text { (M bls) }\end{array}$ \\
\hline Average & 820 & 31 & 0.23 & 210 \\
\hline High & 900 & 50 & 0.41 & 340 \\
\hline Low & 620 & 20 & 0.12 & 140 \\
\hline
\end{tabular}




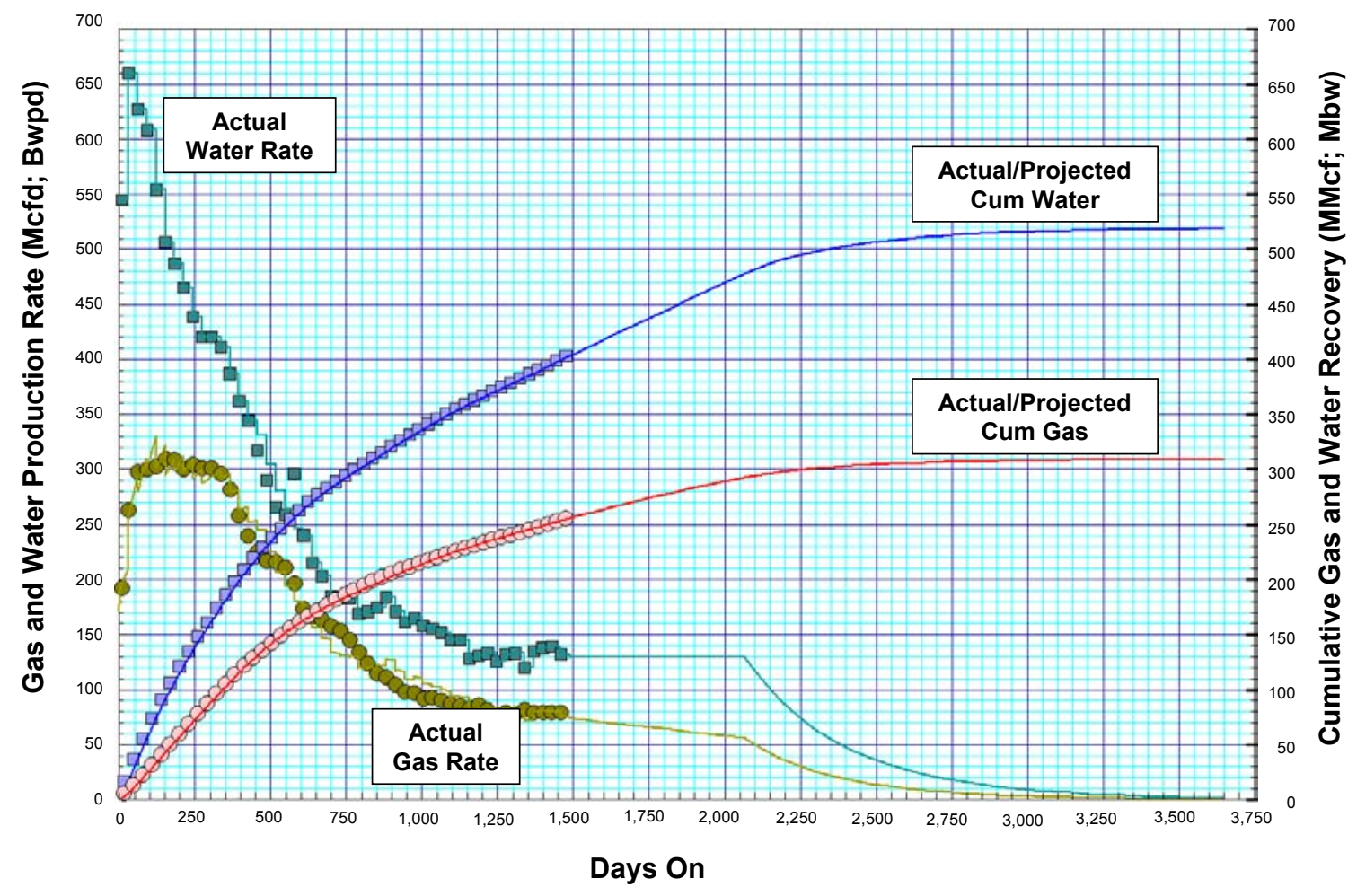

Figure 6-19. Wyodak Type Well, Partition \#4 


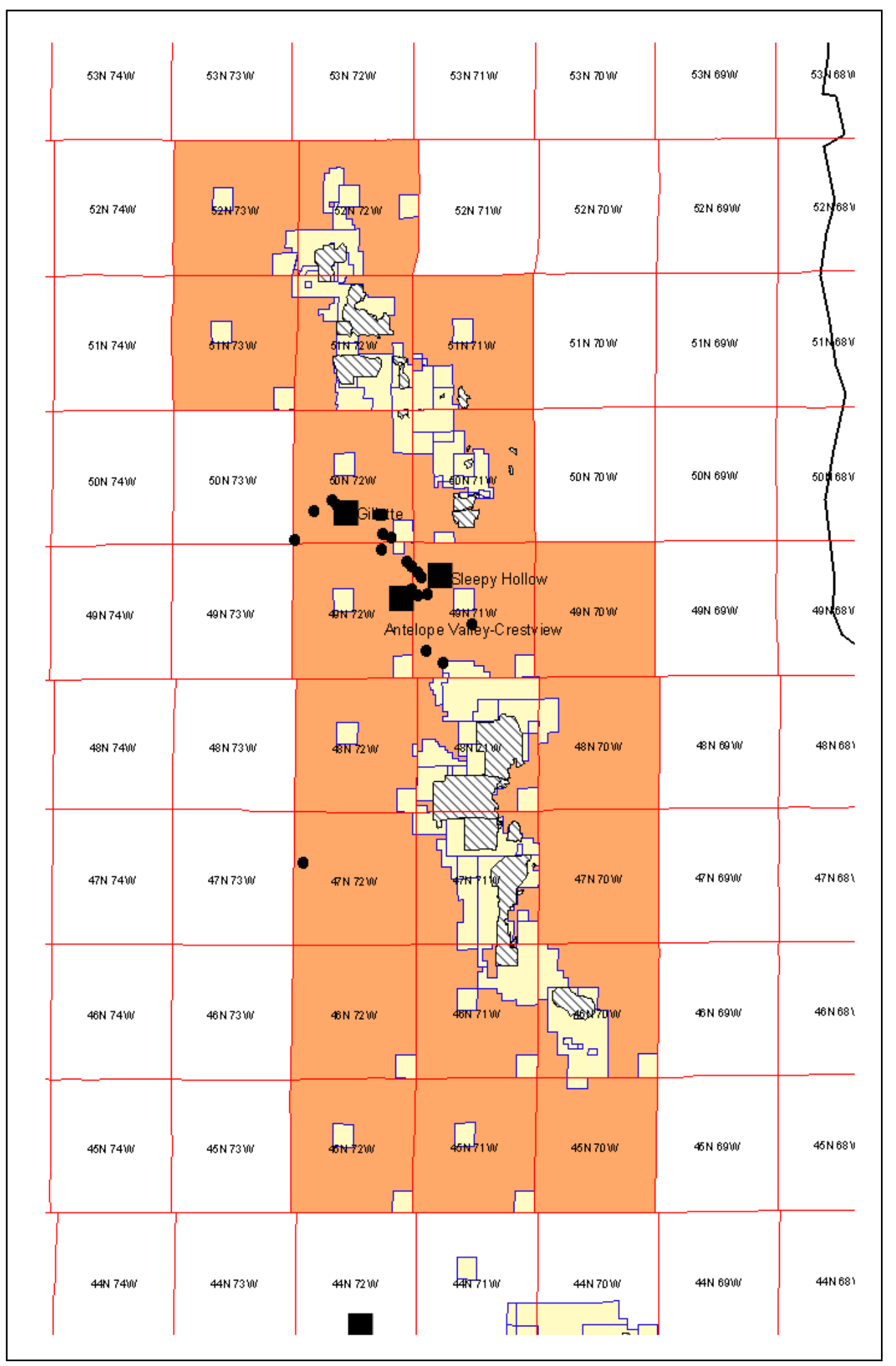

Figure 6-20. Partition \#4 Cook Wells 
- Wall. The Wall seam defines the top of the lower group of Fort Union Formation coals in Partition \#4. The Wall coal seam is stratigraphically below the Cook, separated by an average of 230 feet.

- $\quad$ Area. The Wall coal seam meets study inclusion criteria in 5 townships in the central and western portions of the partition.

- Coal Thickness. The Wall seam coal thickness averages 27 feet, with a range of 20 to 40 feet.

- Coal Depth. The depth to the top of the Wall seam averages 1,020 feet, with a depth range of 800 to 1250 feet.

- Development. The drilled Wall CBM wells are shown in Figure 6-21.

- $\quad$ Time Zero Plot. The time zero plot for 19 producing Wall coal seam wells in Partition \#4 is provided in Figure 6-22. Initial water rates are 300 or more barrels producing for the first year, declining to about 50 barrels per day at the end of year 3. Gas production starts early and peaks at nearly 90 Mcfd during year 1 .

- $\quad$ Type Well. The history-matched type well for Wall coal seam is provided in Figure 6-23. After normalizing for coal thickness, depth and gas content, the estimated gas and water recoveries are as follows in Table 6-17.

Table 6-17. Wall Coal Seam

\begin{tabular}{|l|c|c|c|c|}
\hline \multicolumn{1}{|c|}{ Type Well } & $\begin{array}{c}\text { Well Depth } \\
\text { (ft) }\end{array}$ & $\begin{array}{c}\text { Coal Thickness } \\
\text { (ft) }\end{array}$ & $\begin{array}{c}\text { Cumulative Gas } \\
\text { Recovery } \\
\text { (Bcf) }\end{array}$ & $\begin{array}{c}\text { Cumulative } \\
\text { Water Recovery } \\
\text { (M bls) }\end{array}$ \\
\hline Average & 1,050 & 27 & 0.24 & 460 \\
\hline High & 1,060 & 40 & 0.35 & 680 \\
\hline Low & 970 & 20 & 0.16 & 340 \\
\hline
\end{tabular}

- Pawnee. The Pawnee seam is stratigraphically below the Wall, separated by 275 feet of section.

- $\quad$ Area. The Pawnee coal seam meets study inclusion criteria in 5 townships in the western portion of the partition.

- Coal Thickness. The Pawnee seam coal thickness averages 27 feet with a range of 25 to 30 feet.

- Coal Depth. The depth to the top of the Pawnee seam averages 1,290 feet, with a depth range of 1,150 to 1,500 feet. 


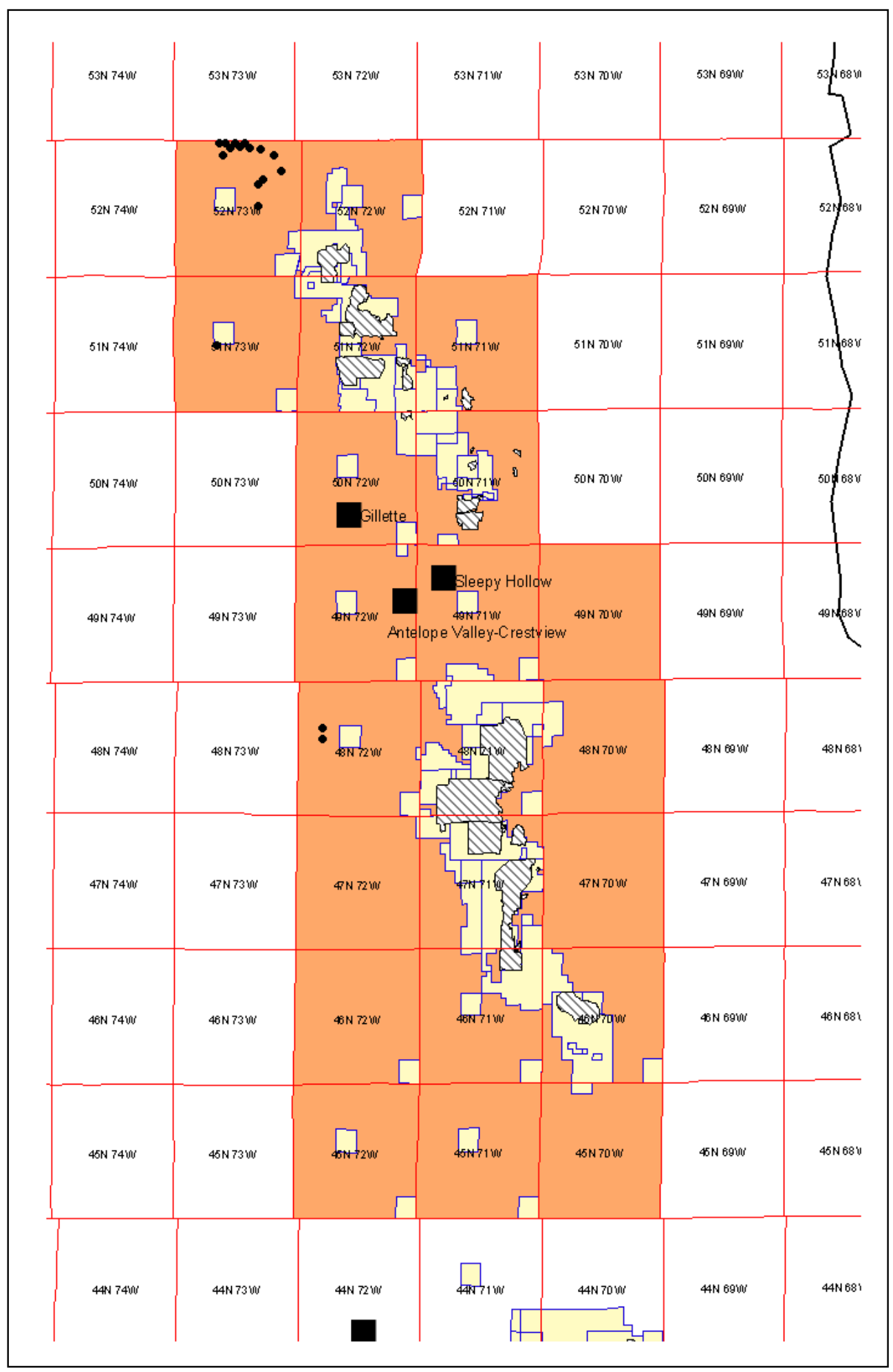

Figure 6-21. Partition \#4 Wall Wells 


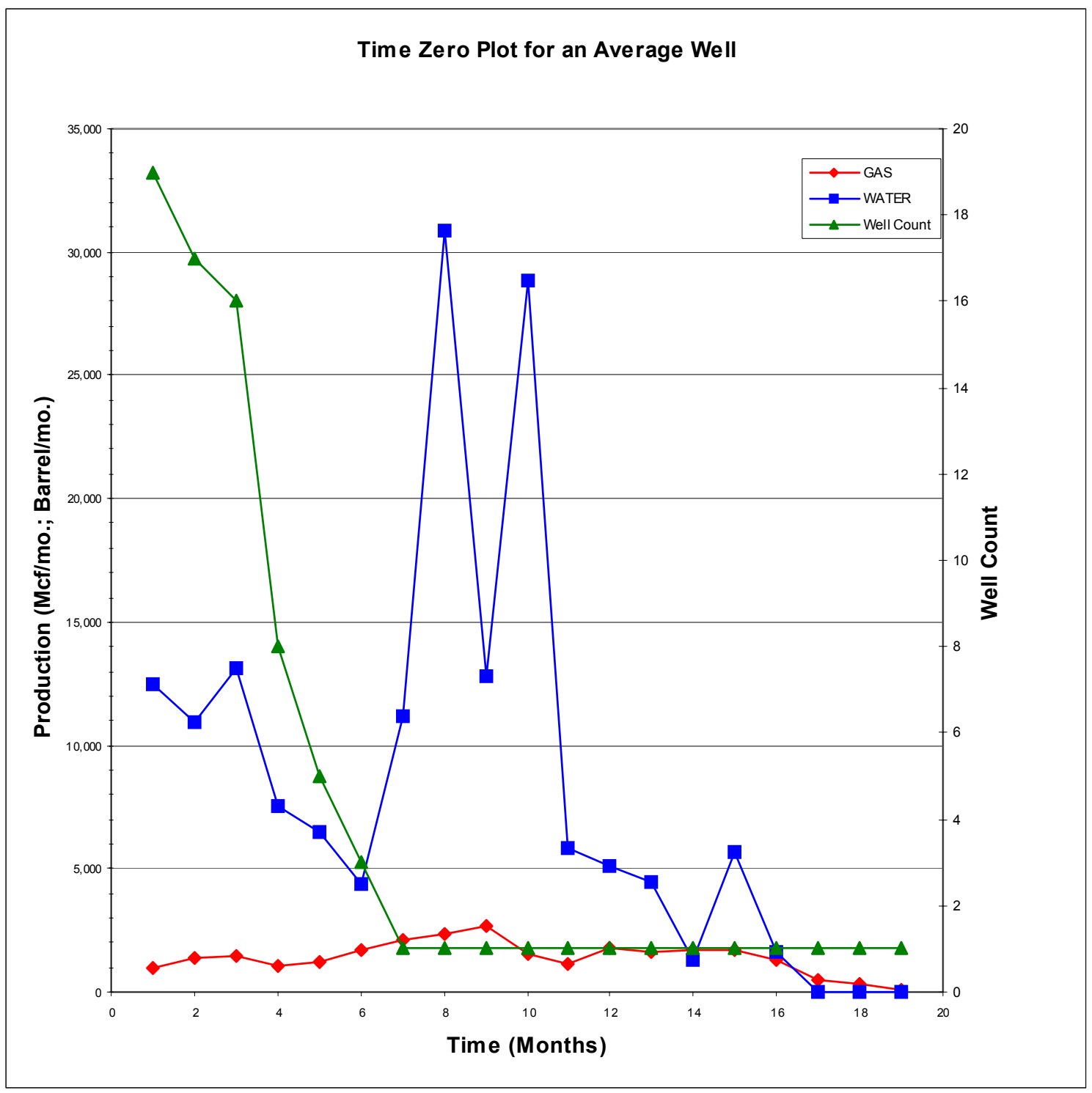

Figure 6-22. Wall Time Zero Plot 


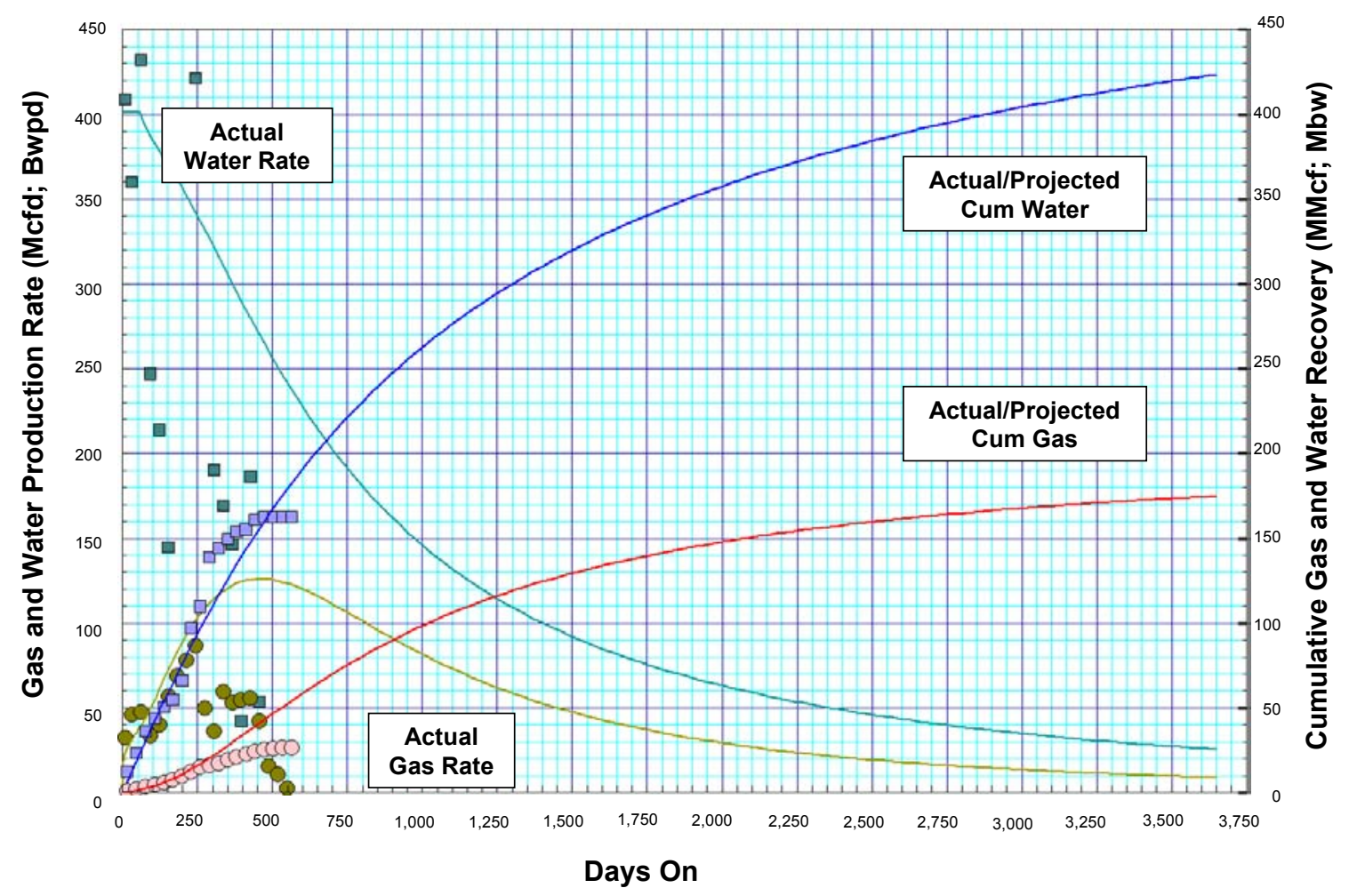

Figure 6-23. Wall Type Well, Partition \#4 
- Development. Figure 6-24 provides the location of the currently drilled Pawnee CBM wells.

- $\quad$ Time Zero Plot. Not available.

- $\quad$ Type Well. The history-matched Pawnee well in Partition \#8, adjusted for depth, gas content, permeability and coal thickness, serves as the Pawnee type well for Partition \#4.

Table 6-18. Pawnee Coal Seam

\begin{tabular}{|l|c|c|c|c|}
\hline \multicolumn{1}{|c|}{ Type Well } & $\begin{array}{c}\text { Well Depth } \\
\text { (ft) }\end{array}$ & $\begin{array}{c}\text { Coal Thickness } \\
\text { (ft) }\end{array}$ & $\begin{array}{c}\text { Cumulative Gas } \\
\text { Recovery } \\
\text { (Bcf) }\end{array}$ & $\begin{array}{c}\text { Cumulative } \\
\text { Water Recovery } \\
\text { (M bls) }\end{array}$ \\
\hline Average & 1,320 & 27 & 0.35 & 360 \\
\hline High & 1,330 & 30 & 0.40 & 400 \\
\hline Low & 1,230 & 25 & 0.30 & 330 \\
\hline
\end{tabular}

- Cache. The Cache coal seam is the basal unit of the lower group of Fort Union coals in Partition \#4. The Cache seam is stratigraphically below the Pawnee, separated by 205 feet of section.

- $\quad$ Area. The Cache coal seam meets study inclusion criteria in 5 townships in the western portion of the partition.

- Coal Thickness. The Cache seam coal thickness averages 23 feet, with a range of 20 to 30 feet.

- Coal Depth. The depth to the top of the Pawnee seam averages 1,500 feet, with a depth range of 1,150 to1,750 feet.

- Development. The Cache seam is lightly developed, as shown in Figure 6-25.

- $\quad$ Time Zero Well. Not available.

- $\quad$ Type Well. The history-matched Pawnee well in Partition \#8, adjusted for depth, gas content, permeability and coal thickness, serves as the Cache type well for Partition \#4. 


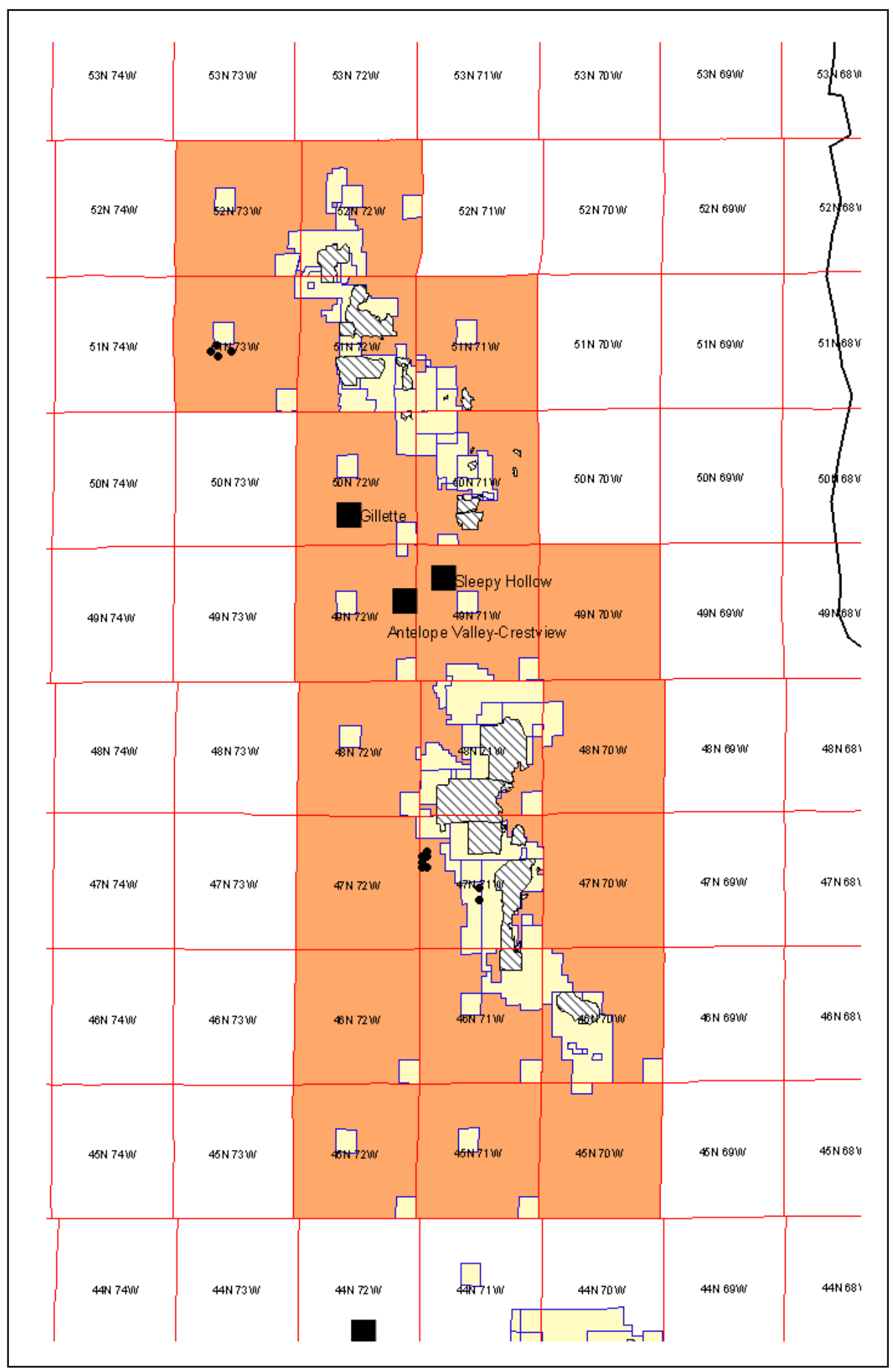

Figure 6-24. Partition \#4 Pawnee Wells 


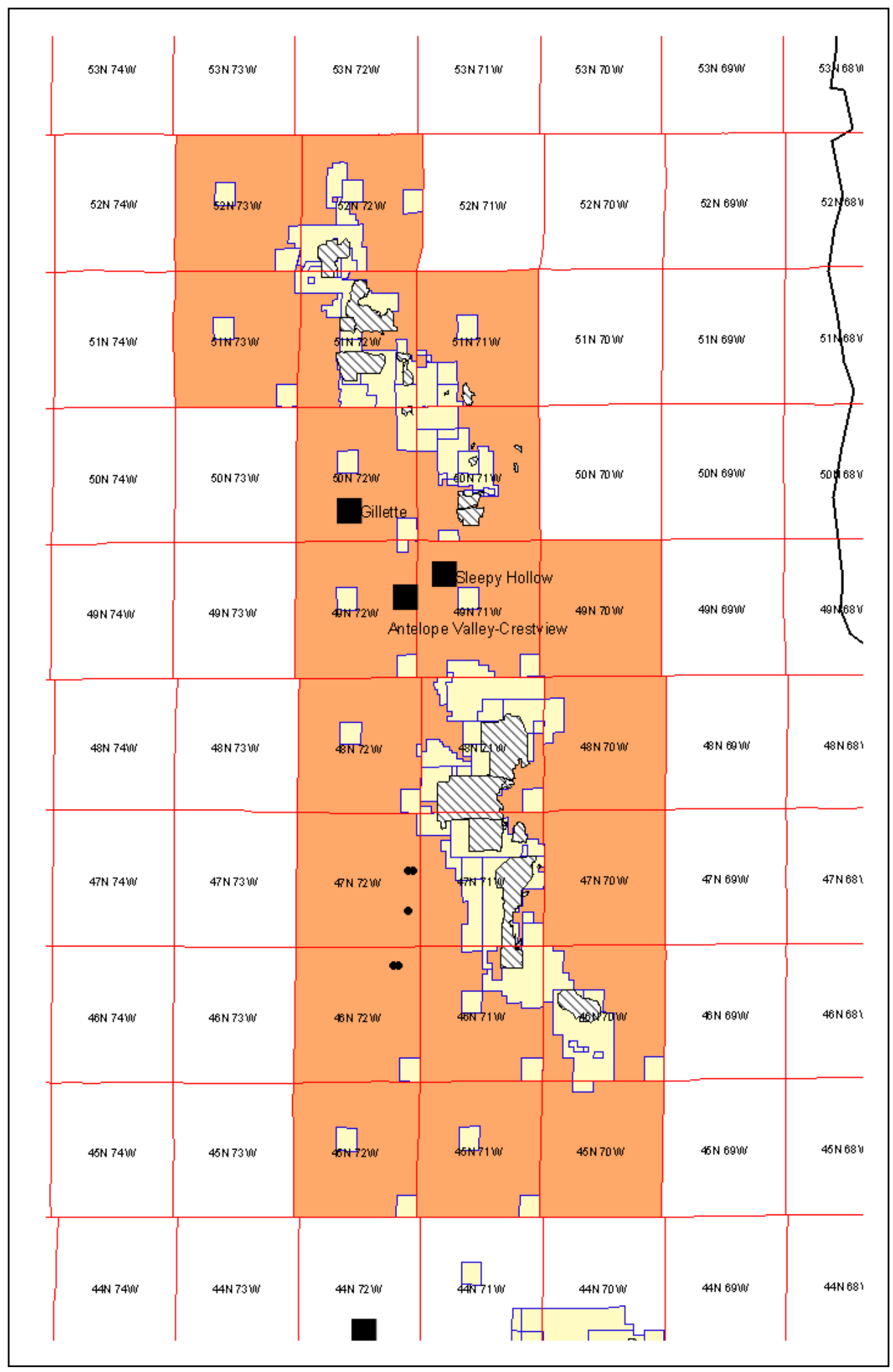

Figure 6-25. Partition \#4 Cache Wells 
Table 6-19. Cache Coal Seam

\begin{tabular}{|l|c|c|c|c|}
\hline \multicolumn{1}{|c|}{ Type Well } & $\begin{array}{c}\text { Well Depth } \\
\text { (ft) }\end{array}$ & $\begin{array}{c}\text { Coal Thickness } \\
\text { (ft) }\end{array}$ & $\begin{array}{c}\text { Cumulative Gas } \\
\text { Recovery } \\
\text { (Bcf) }\end{array}$ & $\begin{array}{c}\text { Cumulative } \\
\text { Water Recovery } \\
\text { (M bls) }\end{array}$ \\
\hline Average & 1,520 & 23 & 0.34 & 300 \\
\hline High & 1,780 & 25 & 0.43 & 330 \\
\hline Low & 1,170 & 20 & 0.23 & 260 \\
\hline
\end{tabular}

Table 6-20. In-Place and Technically Recoverable CBM, Partition \#4

\begin{tabular}{|l||r|r|r|r||r|r|}
\hline Coal Seam & $\begin{array}{c}\text { No. Full } \\
\text { Townships }\end{array}$ & $\begin{array}{c}\text { Average } \\
\text { Depth } \\
\text { (ft) }\end{array}$ & $\begin{array}{c}\text { Average } \\
\text { Thickness } \\
\text { (ft) }\end{array}$ & $\begin{array}{c}\text { Average } \\
\text { Gas Content } \\
\text { (cf/ton) }\end{array}$ & $\begin{array}{c}\text { Gas In } \\
\text { Place } \\
\text { (Bcf) }\end{array}$ & $\begin{array}{c}\text { Technically } \\
\text { Recoverable } \\
\text { (Bcf) }\end{array}$ \\
\hline Anderson & 6 & 450 & 30 & 40 & 400 & 290 \\
\hline Canyon & 12 & 540 & 35 & 47 & 920 & 800 \\
\hline Wyodak & 6 & 601 & 73 & 54 & 890 & 770 \\
\hline Cook & 5 & 790 & 31 & 67 & 450 & 350 \\
\hline Wall & 5 & 1,020 & 27 & 84 & 440 & 350 \\
\hline Pawnee & 5 & 1,295 & 27 & 106 & 570 & 510 \\
\hline Cache & 5 & 1,550 & 23 & 121 & 540 & 480 \\
\hline Totals & 44 & & & & 4,210 & 3,550 \\
\hline
\end{tabular}

* To top of coal

\subsection{Partition \#5}

\subsubsection{Summary}

The main features of Partition \#5, in the central portion of the Powder River Basin, are as follows:

- $\quad$ The partition covers a 38-township area in the PRB, from $45 \mathrm{~N}$ to $52 \mathrm{~N}$ and from $73 \mathrm{~W}$ to $77 \mathrm{~W}$, Figure 6-26.

- Partition \#5 contains 12 major coal seams in the Wasatch and Fort Union Formation. The depth to these coals ranges from 320 to 2,260 feet, with coal seam thickness ranging from 20 to 150 feet (township level averages). The gas in place in the partition is 25.5 Tcf, with technically recoverable gas of 14,910 Bcf. The results by coal seam are provided in Table 6-33. 


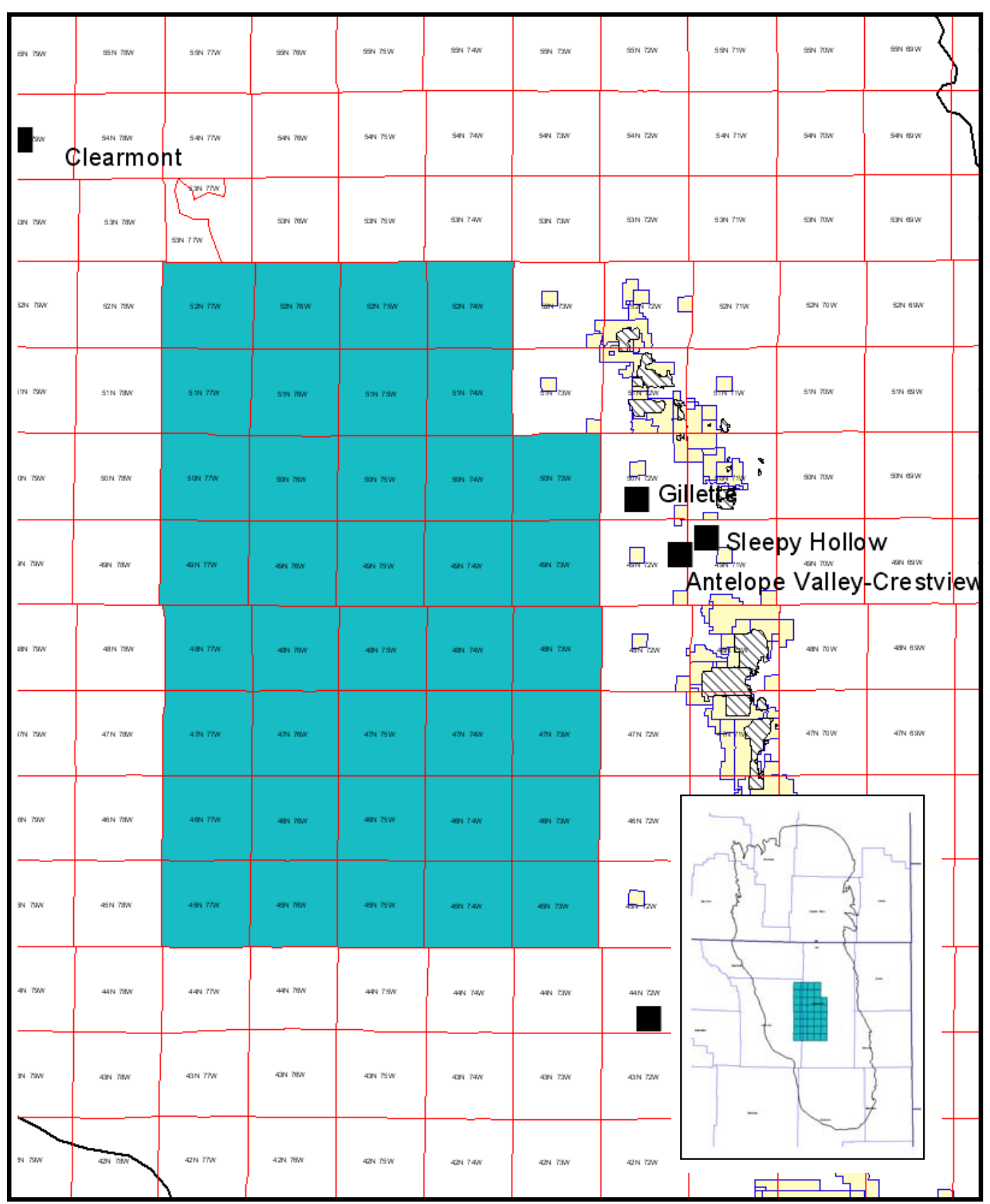

Figure 6-26. Partition \#5 Base Map 


\subsubsection{Discussion of Major Seams}

- Felix. The first major coal seam in Partition \#5 is the Felix. The stratigraphic proximity of the Felix to the adjacent Roland seam provides correlation challenges.

- $\quad$ Area. The Felix coal seam meets study inclusion criteria in 4 townships in the eastern portion of the partition.

- $\quad$ Coal Thickness. The Felix seam coal thickness averages 24 feet, with a range of 20 to 30 feet.

- Coal Depth. The depth to the top of the Felix seam averages 530 feet, with a range of 320 to 780 feet.

- Development. The Felix coal is essentially undeveloped.

- $\quad$ Time Zero Plot. Not available.

- $\quad$ Type Well. After adjustment for depth, gas content, permeability and coal thickness, the type well for the Smith coal seam in Partition \#5, discussed later, serves as the type well for the Felix coal seam in this partition.

\section{Table 6-21. Felix Coal Seam}

\begin{tabular}{|l|c|c|c|c|}
\hline Type Well & $\begin{array}{c}\text { Well Depth } \\
\text { (ft) }\end{array}$ & $\begin{array}{c}\text { Coal Thickness } \\
\text { (ft) }\end{array}$ & $\begin{array}{c}\text { Cumulative Gas } \\
\text { Recovery } \\
\text { (Bcf) }\end{array}$ & $\begin{array}{c}\text { Cumulative } \\
\text { Water Recovery } \\
\text { (M bls) }\end{array}$ \\
\hline Average & 555 & 24 & 0.12 & 90 \\
\hline
\end{tabular}

- Roland. The Roland seam is stratigraphically below the Felix. Like the Felix, the Roland presents correlation problems in the eastern portion of the partition due the proximity of adjacent coal seams.

- $\quad$ Area. The Roland coal seam meets study inclusion criteria in only 2 townships located in the northern portion of the partition.

- Coal Thickness. The Roland coal seam thickness averages 25 feet, with a range of 20 to 30 feet.

- $\quad$ Coal Depth. The depth to the top of the Roland seam averages 540 feet.

- Development. The Roland coal is essentially undeveloped.

- $\quad$ Time Zero Plot. Not available. 
- $\quad$ Type Well. After adjustment for depth, gas content, permeability and coal thickness, the type well for the Smith coal seam in Partition \#5, discussed later, serves as the type well for the Roland coal seam in this partition.

Table 6-22. Roland Coal Seam

\begin{tabular}{|l|c|c|c|c|}
\hline Type Well & $\begin{array}{c}\text { Well Depth } \\
\text { (ft) }\end{array}$ & $\begin{array}{c}\text { Coal Thickness } \\
\text { (ft) }\end{array}$ & $\begin{array}{c}\text { Cumulative Gas } \\
\text { Recovery } \\
\text { (Bcf) }\end{array}$ & $\begin{array}{c}\text { Cumulative } \\
\text { Water Recovery } \\
\text { (M bls) }\end{array}$ \\
\hline Average & 565 & 25 & 0.13 & 100 \\
\hline
\end{tabular}

- Smith. The Smith seam lies stratigraphically below the Roland seam and is a significant coal seam in Partition \#5.

- $\quad$ Area. The Smith coal seam meets study inclusion criteria in 18 townships located throughout the partition.

- Coal Thickness. The Smith seam coal thickness averages 40 feet, with a range of 25 to 60 feet.

- Coal Depth. The depth to the top of the Smith seam averages 820 feet, with a depth range of 320 to 1,200 feet.

- Development. The are a total of 339 drilled or permitted Smith CBM wells in Partition \#5.

- $\quad$ Time Zero Plot. The time zero plot for 10 producing Smith coal seam wells is provided in Figure 6-27. Initial water rates are at 130 barrels per day declining to about 70 barrels per day after 6 months. Gas production increases steadily, reaching 40 Mcfd during year 1 .

- $\quad$ Type Well. The history-matched type well for the Smith coal seam is provided in Figure 6-28. After normalizing for coal thickness, depth and gas content, the estimated gas and water recoveries are as follows.

Table 6-23. Smith Coal Seam

\begin{tabular}{|l|c|c|c|c|}
\hline \multicolumn{1}{|c|}{ Type Well } & $\begin{array}{c}\text { Well Depth } \\
\text { (ft) }\end{array}$ & $\begin{array}{c}\text { Coal Thickness } \\
\text { (ft) }\end{array}$ & $\begin{array}{c}\text { Cumulative Gas } \\
\text { Recovery } \\
\text { (Bcf) }\end{array}$ & $\begin{array}{c}\text { Cumulative } \\
\text { Water Recovery } \\
\text { (M bls) }\end{array}$ \\
\hline Average & 860 & 40 & 0.31 & 150 \\
\hline High & 1160 & 60 & 0.47 & 230 \\
\hline Low & 500 & 25 & 0.12 & 100 \\
\hline
\end{tabular}

- Swartz. Stratigraphically, the Swartz seam is between the overlying Smith seam and the underlying Anderson coal seam. 


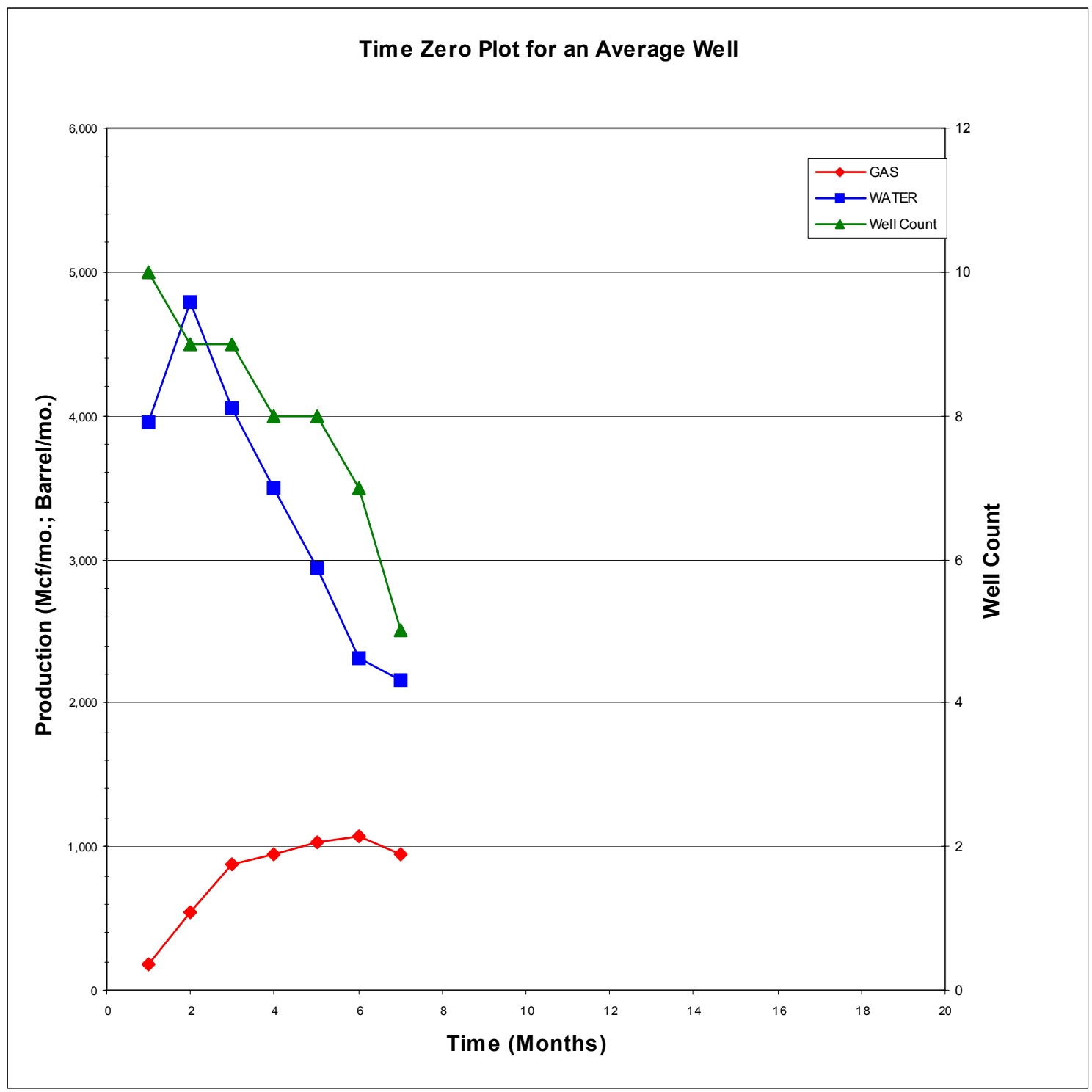

Figure 6-27. Smith Time Zero Plot 


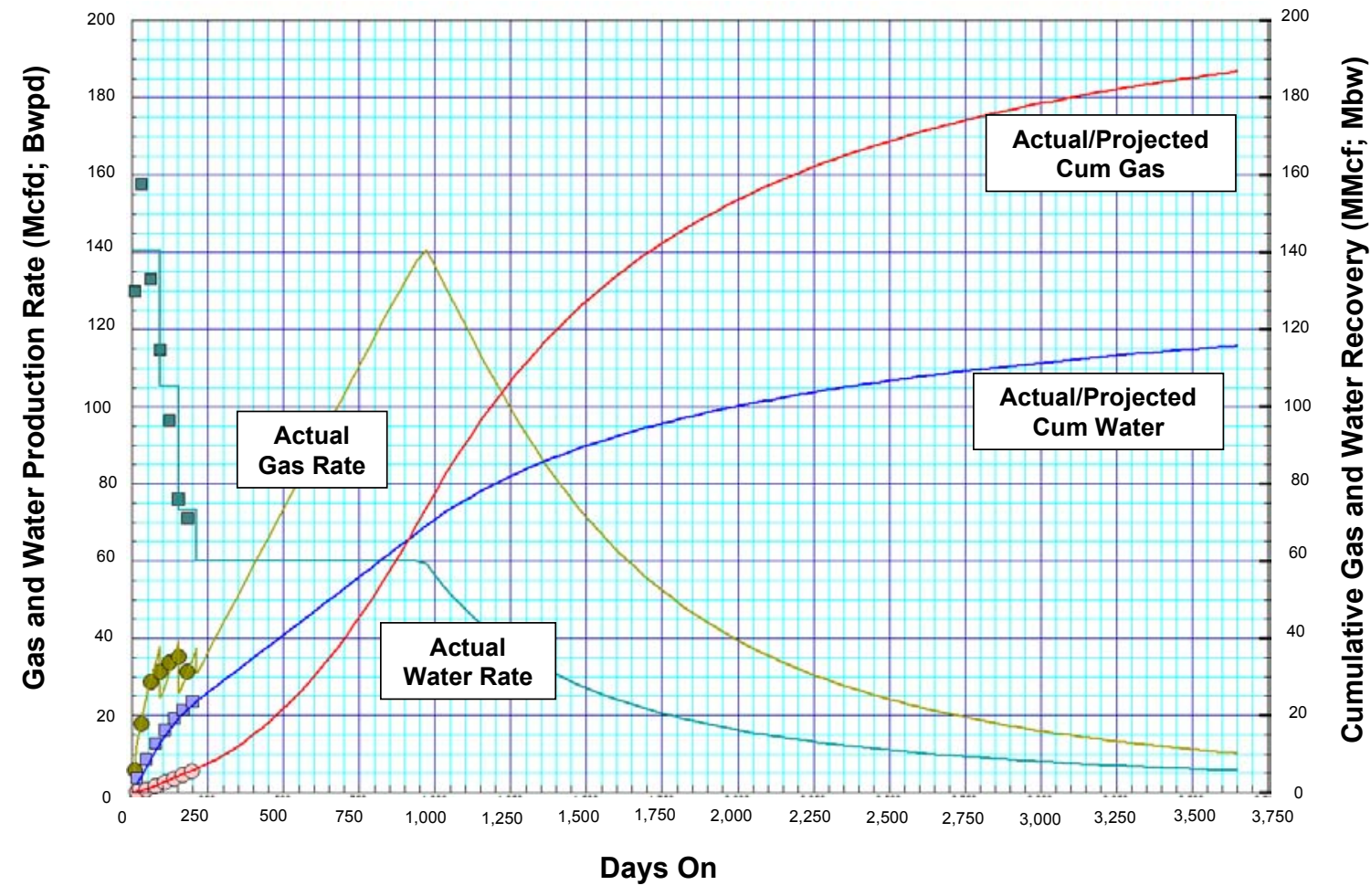

Figure 6-28. Smith Type Well, Partition \#5 
- $\quad$ Area. The Swartz coal seam meets study inclusion criteria in 2 townships in the northern portion of the partition.

- Coal Thickness. The Swartz seam coal thickness averages 43 feet, with a range of 40 to 45 feet.

- Coal Depth. The depth to the top of the Swartz seam averages 740 feet, with a depth range of 700 to 770 feet.

- Development. The Swartz coal is essentially undeveloped.

- $\quad$ Time Zero Well. Not available.

- $\quad$ Type Well. The history-matched Smith well in Partition \#5, adjusted for depth, gas content, permeability and coal thickness, serves as the Swartz type well in this partition.

Table 6-24. Swartz Coal Seam

\begin{tabular}{|l|c|c|c|c|}
\hline Type Well & $\begin{array}{c}\text { Well Depth } \\
\text { (ft) }\end{array}$ & $\begin{array}{c}\text { Coal Thickness } \\
\text { (ft) }\end{array}$ & $\begin{array}{c}\text { Cumulative Gas } \\
\text { Recovery } \\
\text { (Bcf) }\end{array}$ & $\begin{array}{c}\text { Cumulative } \\
\text { Water Recovery } \\
\text { (M bls) }\end{array}$ \\
\hline Average & 785 & 43 & 0.30 & 160 \\
\hline
\end{tabular}

- Anderson. The Anderson coal seam is stratigraphically below the Swartz, separated by an average of 300 feet of section. The Anderson seam is often included with the Canyon seam or the Wyodak elsewhere in the Powder River Basin.

- $\quad$ Area. The Anderson coal seam meets study inclusion criteria in 9 townships.

- Coal Thickness. The Anderson seam coal thickness averages 38 feet, with a range of 25 to 60 feet.

- Coal Depth. The depth to the top of the Anderson seam averages 1,030 feet, with a depth range of 800 to 1,400 feet.

- Development. The are a total of 362 drilled or permitted Anderson CBM wells in Partition \#5.

- $\quad$ Time Zero Plot. The time zero plot for 216 producing Anderson coal seam wells in Partition \#5 is provided in Figure 6-29. Initial water rates remain high, at 250 to 300 barrels per day through the first 2 years. Gas production starts early and reaches 60 Mcfd during year 1, indicating the presence of free gas. 


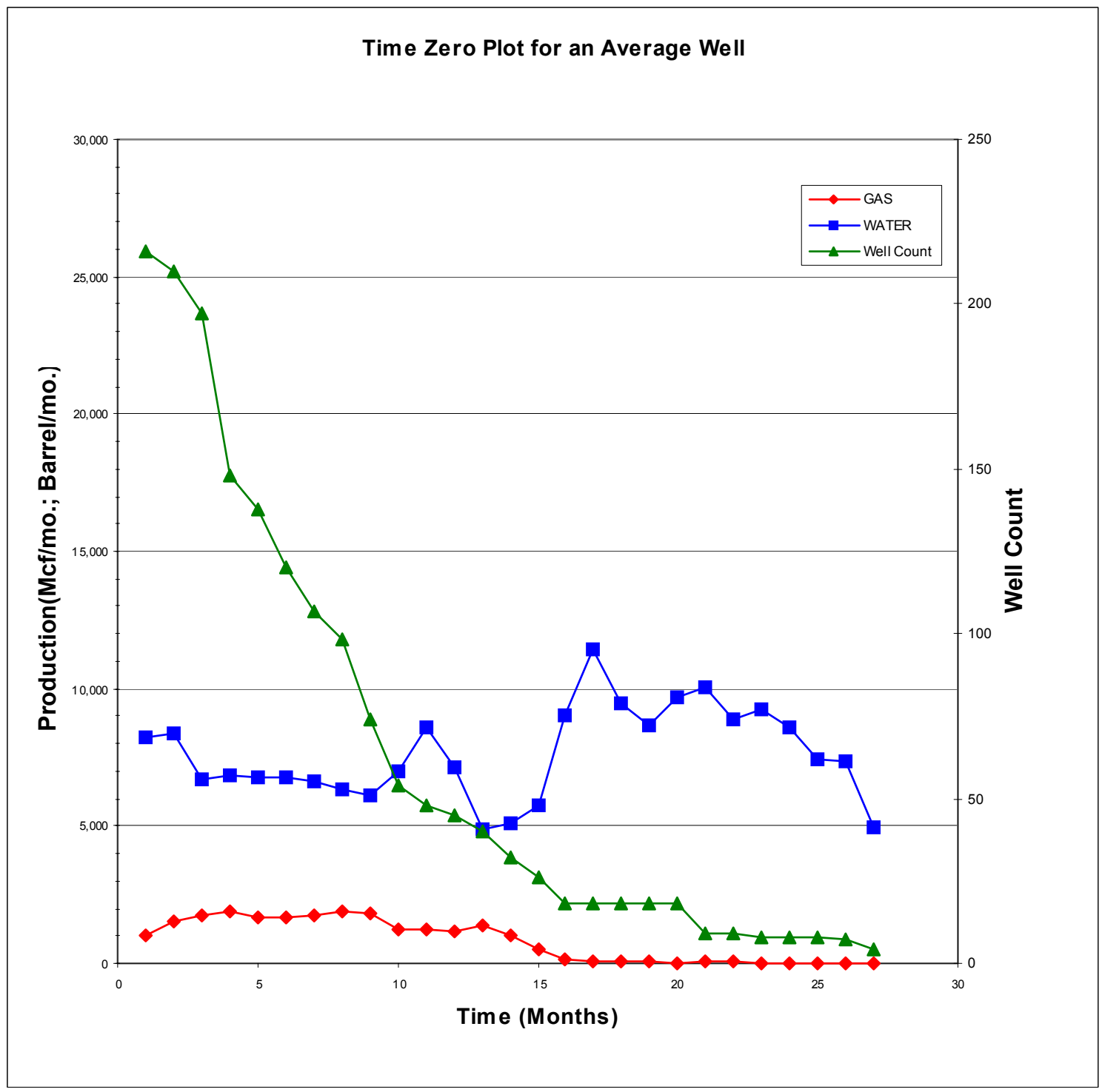

Figure 6-29. Anderson Time Zero Plot 
- $\quad$ Type Well. The history-matched Anderson well in Partition \#8, adjusted for depth, gas content, permeability and coal thickness, serves as the Anderson type well in this partition.

Table 6-25. Anderson Coal Seam

\begin{tabular}{|l|c|c|c|c|}
\hline \multicolumn{1}{|c|}{ Type Well } & $\begin{array}{c}\text { Well Depth } \\
\text { (ft) }\end{array}$ & $\begin{array}{c}\text { Coal Thickness } \\
\text { (ft) }\end{array}$ & $\begin{array}{c}\text { Cumulative Gas } \\
\text { Recovery } \\
\text { (Bcf) }\end{array}$ & $\begin{array}{c}\text { Cumulative } \\
\text { Water Recovery } \\
\text { (M bls) }\end{array}$ \\
\hline Average & 1070 & 38 & 0.33 & 100 \\
\hline High & 860 & 60 & 0.43 & 160 \\
\hline Low & 920 & 25 & 0.20 & 70 \\
\hline
\end{tabular}

- Canyon. The Canyon seam is the most intensely developed coal seam in Partition \#5.

- $\quad$ Area. The Canyon coal seam meets study inclusion criteria in 16 townships throughout the partition.

- Coal Thickness. The Canyon seam coal thickness averages 39 feet with a range of 30 to 55 feet.

- Coal Depth. The depth to the top of the Canyon seam averages 1,060 feet, with a depth range of 700 to 1,400 feet.

- Development. A total of 1,610 drilled or permitted Canyon CBM wells exist in Partition \#5.

- $\quad$ Time Zero Plot. The time zero plot for 73 producing Canyon coal seam wells in Partition \#5 is provided in Figure 6-30. Initial water rates are high, at 300 to 450 barrels per day, dropping to about 130 barrels per day after 18 months. Gas production reaches $80 \mathrm{Mcfd}$ after 6 months.

- $\quad$ Type Well. The history-matched Canyon well in Partition \#4, adjusted for depth, gas content, permeability and coal thickness, serves as the Canyon type well for Partition \#5.

Table 6-26. Canyon Coal Seam

\begin{tabular}{|l|c|c|c|c|}
\hline \multicolumn{1}{|c|}{ Type Well } & $\begin{array}{c}\text { Well Depth } \\
\text { (ft) }\end{array}$ & $\begin{array}{c}\text { Coal Thickness } \\
\text { (ft) }\end{array}$ & $\begin{array}{c}\text { Cumulative Gas } \\
\text { Recovery } \\
\text { (Bcf) }\end{array}$ & $\begin{array}{c}\text { Cumulative } \\
\text { Water Recovery } \\
\text { (M bls) }\end{array}$ \\
\hline Average & 1,100 & 39 & 0.32 & 300 \\
\hline High & 1,060 & 55 & 0.43 & 420 \\
\hline Low & 1,030 & 30 & 0.23 & 230 \\
\hline
\end{tabular}




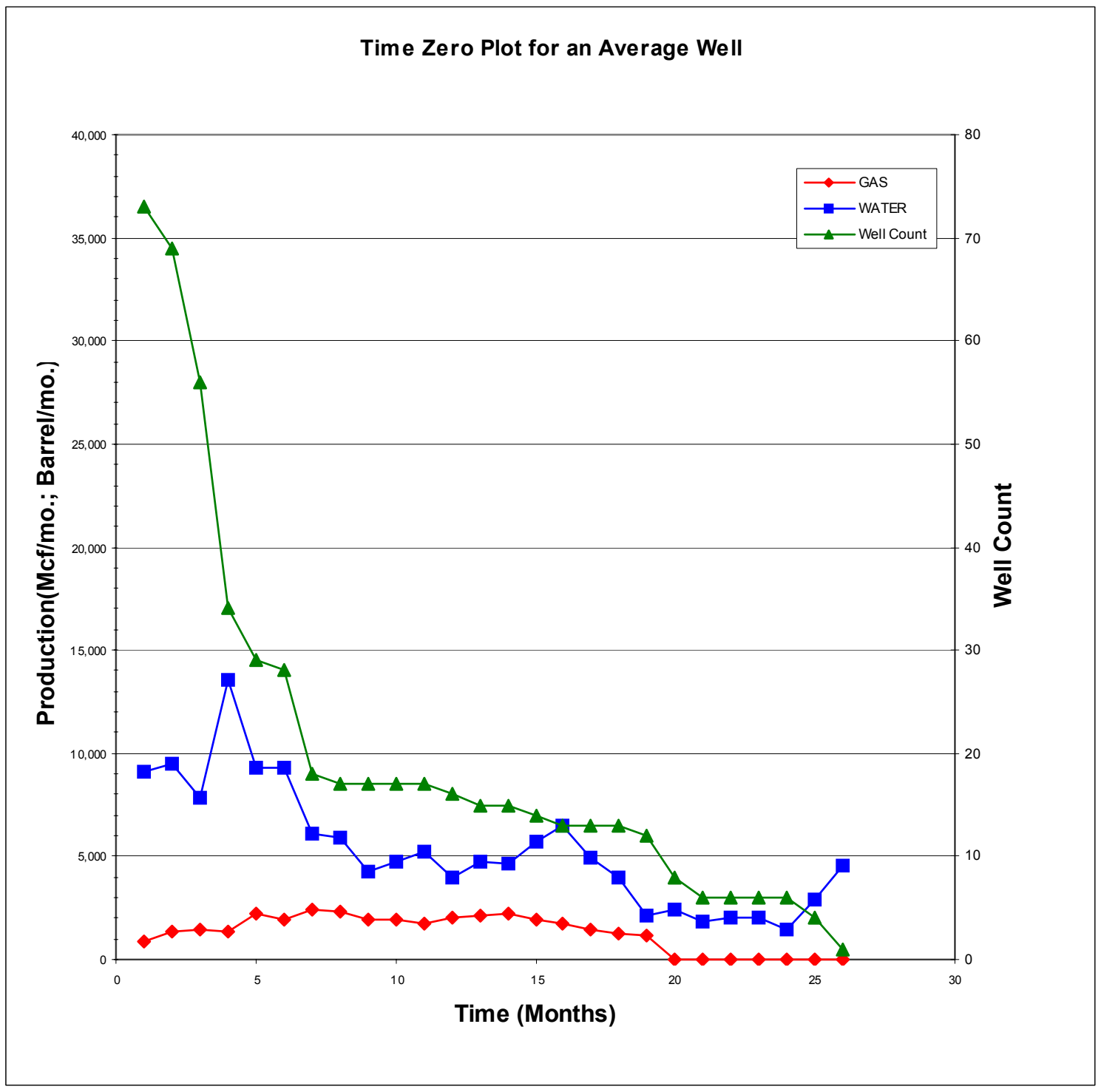

Figure 6-30. Canyon Time Zero Plot 
- Big George. The Big George is the second most intensely developed seam in Partition \#5. It lies approximately 200 feet deeper than the Canyon seam and is equivalent to the Wyodak coal in the eastern portion of this partition.

- $\quad$ Area. The Big George coal seam meets study inclusion criteria in 16 townships in the central and southern portions of the partition.

- Coal Thickness. The Big George seam coal thickness averages 97 feet, with a range of 80 to 140 feet.

- Coal Depth. The depth to the top of the Big George seam averages 1,280 feet, with a depth range of 1,150 to1,460 feet.

- Development. The are a total of 1,027 drilled or permitted Big George CBM wells in Partition \#5.

- $\quad$ Time Zero Well. The time zero plot for 121 producing Big George coal seam wells in Partition \#5 is provided in Figure 6-31. Initial water rates start at 480 barrels per day, climbing to a peak late in year 2 at 1,800 barrels per day. Water rates drop off only slightly at the end of year 2 to 1,330 barrels per day. Gas production begins slowly and gradually peaks at $270 \mathrm{Mcfd}$ after 20 months. The time zero plot for the Big George wells in Partition \#5 shows constraints in water production during initial production. Therefore, a relatively intensely drilled area of the partition, Sec. 16 T44N, R77W, was examined in more detail. The location of these wells and the elevation map for the section is provided in Figure 6-32. These 17 wells were combined to establish the time zero plot for the Big George coal well in Partition \#5, Figure 6-33.

- $\quad$ Type Well. The history-matched Big George coal seam well in Partition \#5 was used to develop the 80 acre type well in Figure 6-34. After normalizing for coal thickness, depth, and gas content, the estimated gas and water recoveries are as follows in Table 6-27.

Table 6-27. Big George Coal Seam

\begin{tabular}{|l|c|c|c|c|}
\hline \multicolumn{1}{|c|}{ Type Well } & $\begin{array}{c}\text { Well Depth } \\
\text { (ft) }\end{array}$ & $\begin{array}{c}\text { Coal Thickness } \\
\text { (ft) }\end{array}$ & $\begin{array}{c}\text { Cumulative Gas } \\
\text { Recovery } \\
\text { (Bcf) }\end{array}$ & $\begin{array}{c}\text { Cumulative } \\
\text { Water Recovery } \\
\text { (M bls) }\end{array}$ \\
\hline Average & 1,380 & 97 & 0.69 & 1,520 \\
\hline High & 1,440 & 140 & 1.05 & 2,210 \\
\hline Low & 1,320 & 80 & 0.56 & 1,260 \\
\hline
\end{tabular}

- Wyodak. Essentially an equivalent of the thick Big George seam, the Wyodak coal seam exists only on the eastern side of the partition, adjacent to Partition \#4. 


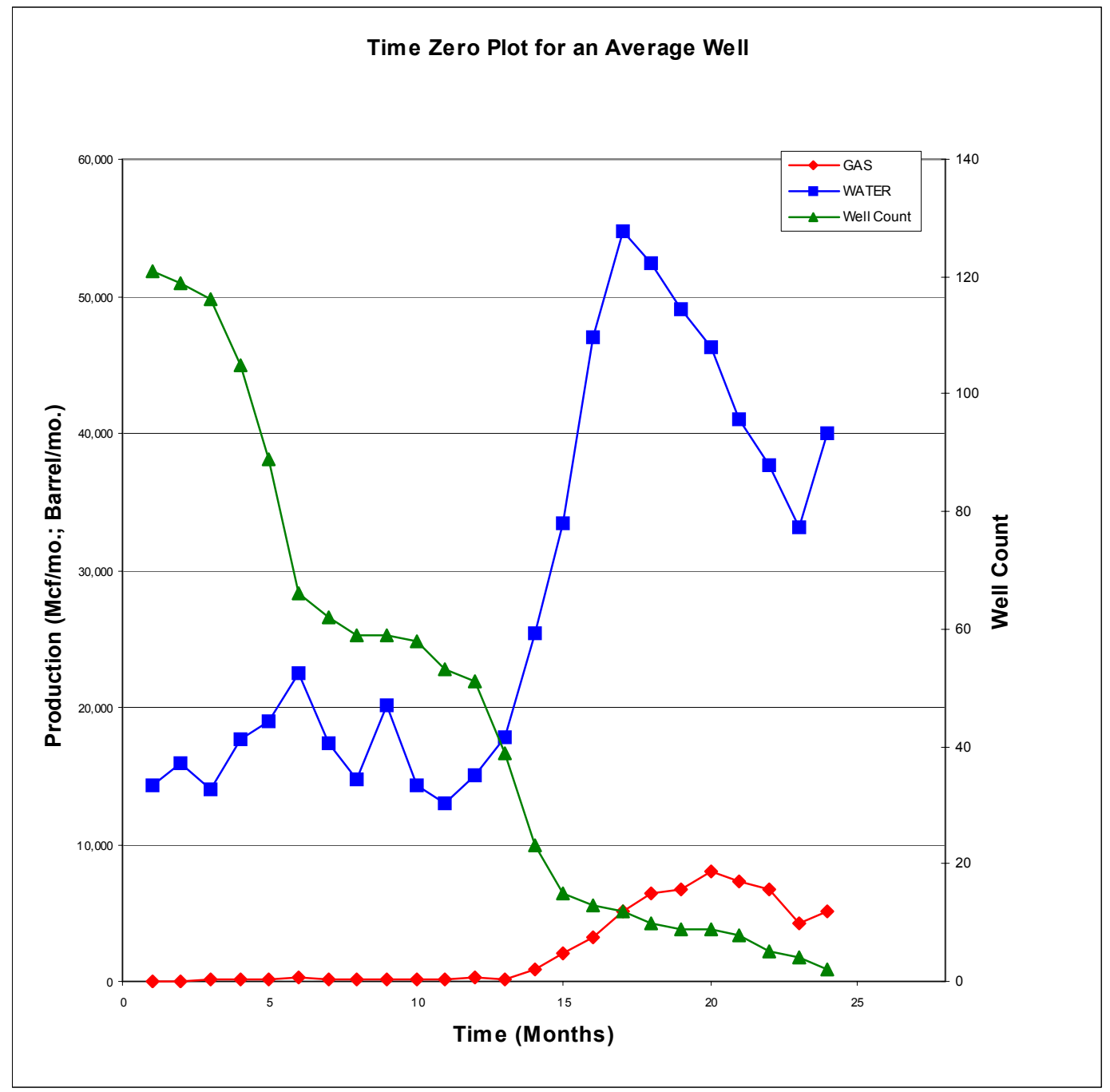

Figure 6-31. Big George Coal Seam - Aggregate 


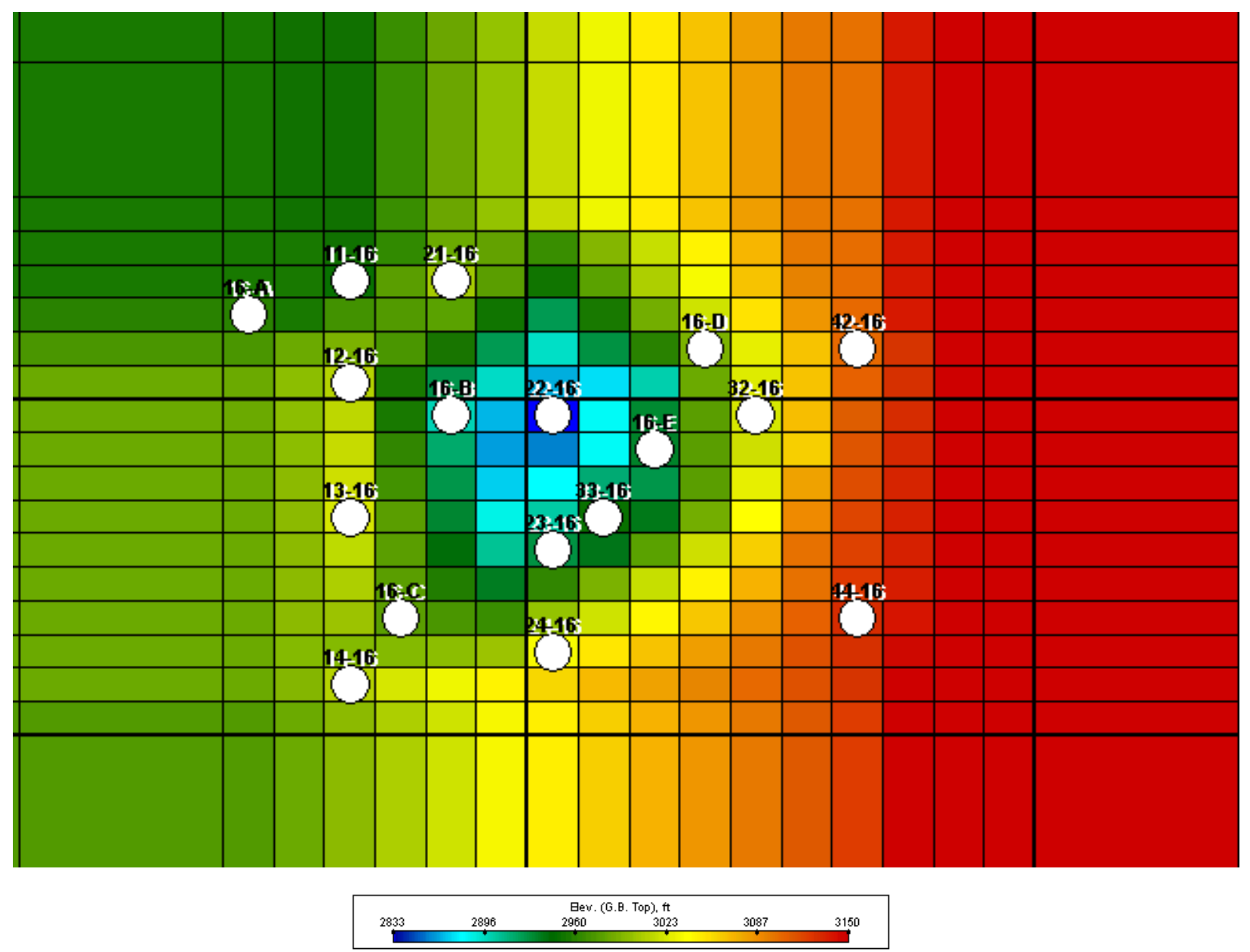

Figure 6-32. Big George Coal Seam Well Location and Elevation Map, Partition \#5. 


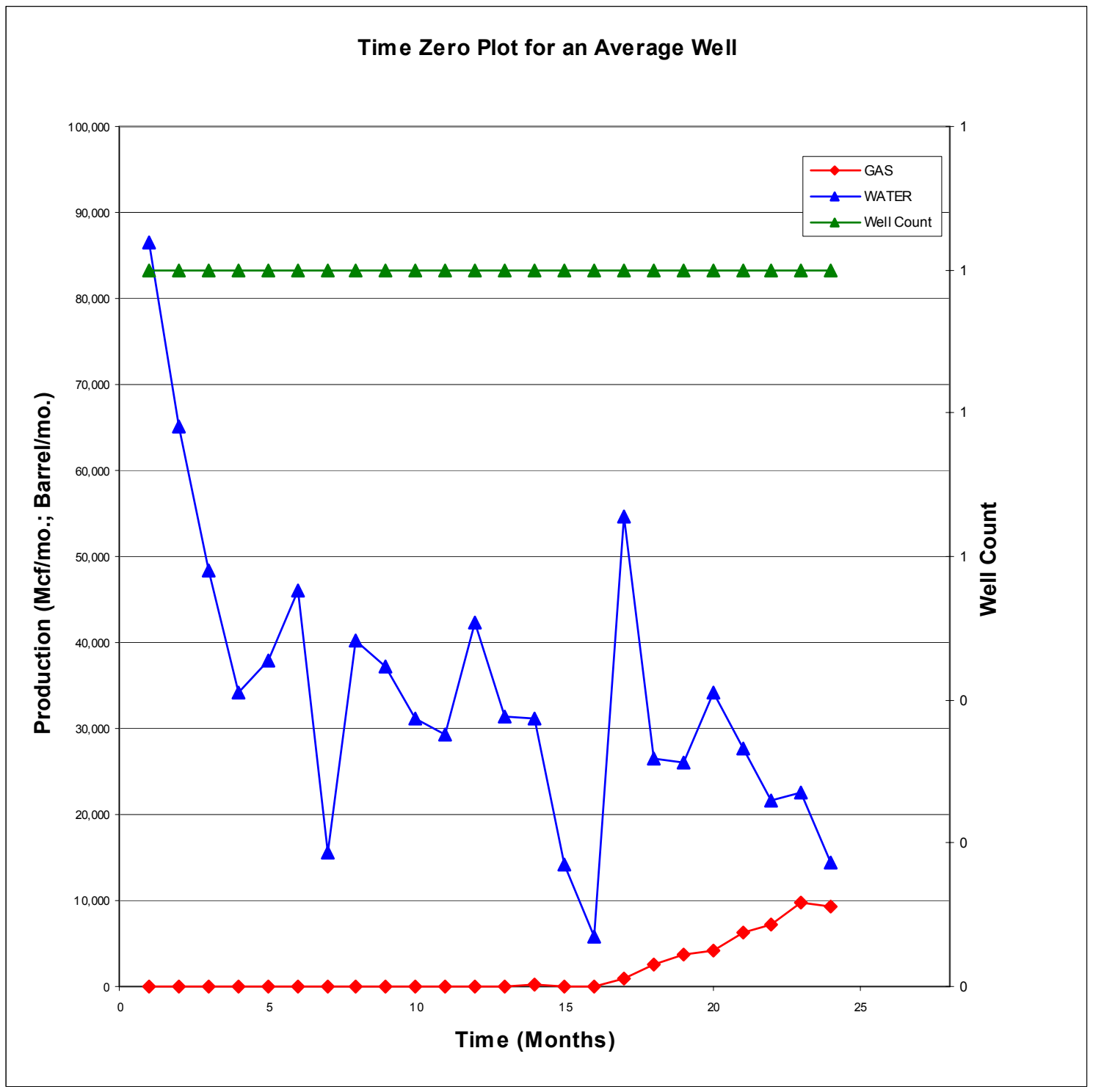

Figure 6-33. Big George Time Zero Plot 


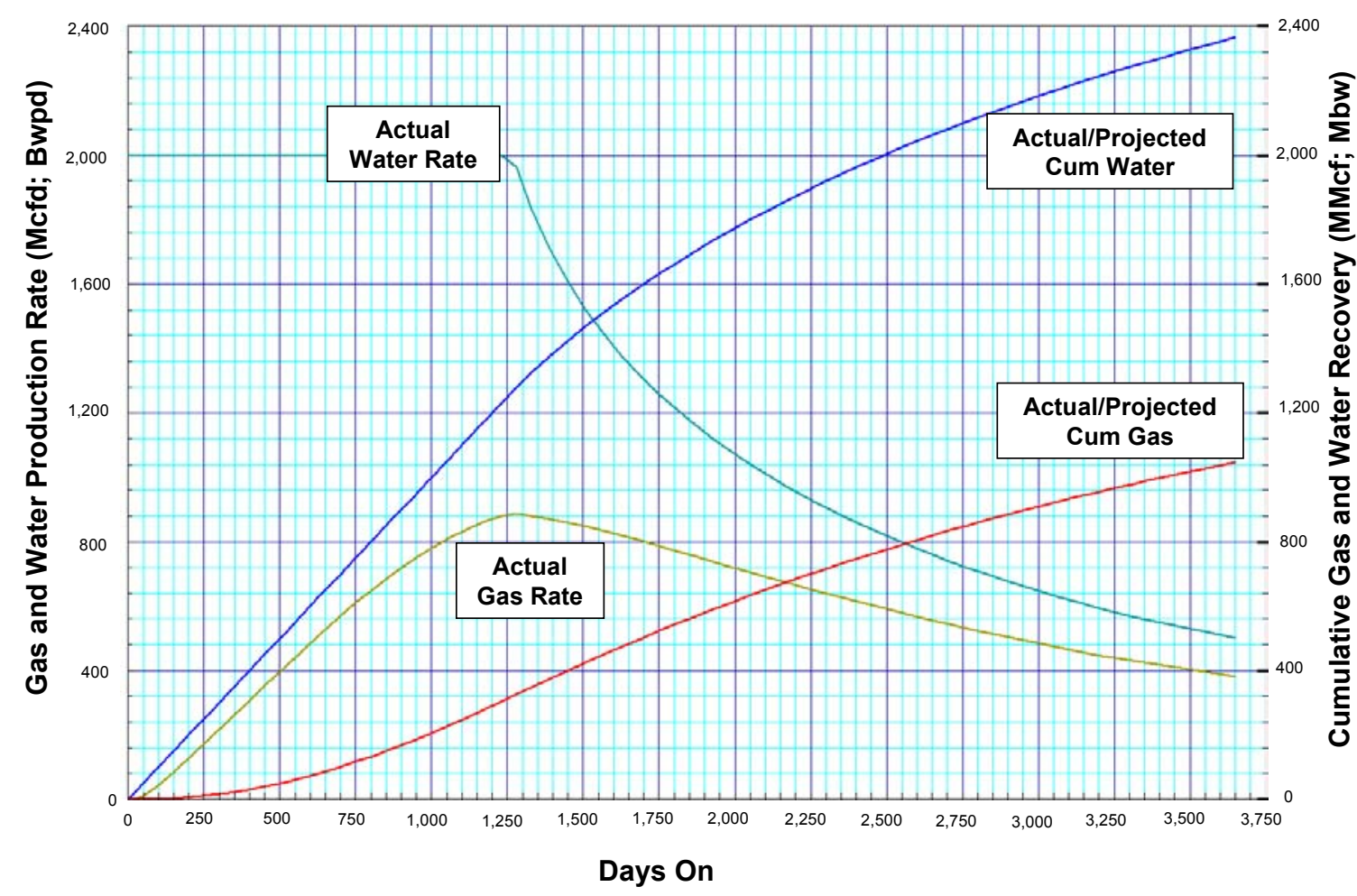

Figure 6-34. Big George Type Well Partition \#5 
- $\quad$ Area. The Wyodak coal seam meets study inclusion criteria in 2 townships in the southeastern portion of the partition.

- Coal Thickness. The Wyodak seam coal thickness averages 73 feet, with a range of 70 to 75 feet.

- Coal Depth. The depth to the top of the Wyodak seam averages 1,000 feet, with a depth range of 950 to 1,050 .

- Development. The Wyodak coal seam is extensively developed with nearly 700 drilled or permitted wells in Partition \#5.

- $\quad$ Time Zero Well. The time zero plot for 442 producing Wyodak coal seam wells in Partition \#5 is provided in Figure 6-35. Initial water rates start at 270 barrels per day. Gas production begins early at about $60 \mathrm{Mcfd}$ and increases steadily to nearly $220 \mathrm{Mcfd}$ at the end of 2 years.

- $\quad$ Type Well. The history-matched Wyodak well in Partition \#4, adjusted for depth, gas content, permeability and coal thickness, serves as the type well for Partition \#5. Because the Wyodak coal exists in only two townships with relatively uniform production, only an average well is used.

Table 6-28. Wyodak Coal Seam

\begin{tabular}{|l|c|c|c|c|}
\hline Type Well & $\begin{array}{c}\text { Well Depth } \\
\text { (ft) }\end{array}$ & $\begin{array}{c}\text { Coal Thickness } \\
\text { (ft) }\end{array}$ & $\begin{array}{c}\text { Cumulative Gas } \\
\text { Recovery } \\
\text { (Bcf) }\end{array}$ & $\begin{array}{c}\text { Cumulative } \\
\text { Water Recovery } \\
\text { (M bls) }\end{array}$ \\
\hline Average & 1,075 & 73 & 0.37 & 480 \\
\hline
\end{tabular}

- Cook. The Cook seam defines the base of the upper group of Fort Union coals in Partition \#5. The proximity of the Cook seam to the basal boundary of the Wyodak and equivalents poses correlation problems throughout the partition.

- $\quad$ Area. The Cook coal seam meets study inclusion criteria in 17 townships throughout the partition.

- Coal Thickness. The Cook seam coal thickness averages 40 feet, with a range of 25 to 60 feet.

- Coal Depth. The depth to the top of the Cook seam averages 1,320 feet, with a depth range of 900 to 1,700 .

- Development. A total of 1,321 drilled or permitted Cook CBM wells exist in Partition \#5.

- $\quad$ Time Zero Well. Not available. 


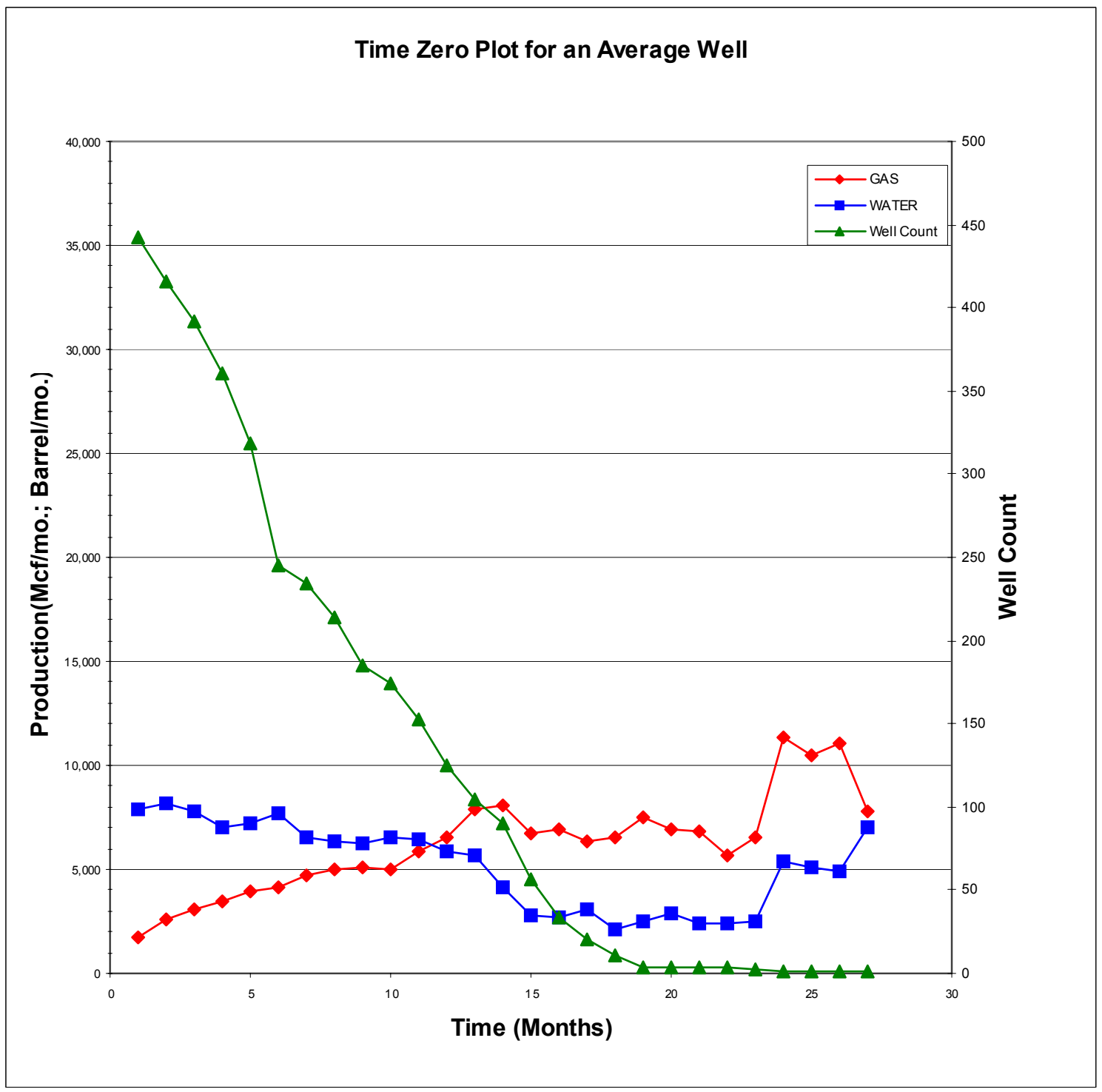

Figure 6-35. Wyodak Time Zero Plot 
- $\quad$ Type Well. The history-matched Cook well in Partition \#8, adjusted for depth, gas content, permeability and coal thickness, serves as the Cook type well for Partition \#5.

Table 6-29. Cook Coal Seam

\begin{tabular}{|l|c|c|c|c|}
\hline \multicolumn{1}{|c|}{ Type Well } & $\begin{array}{c}\text { Well Depth } \\
\text { (ft) }\end{array}$ & $\begin{array}{c}\text { Coal Thickness } \\
\text { (ft) }\end{array}$ & $\begin{array}{c}\text { Cumulative Gas } \\
\text { Recovery } \\
\text { (Bcf) }\end{array}$ & $\begin{array}{c}\text { Cumulative } \\
\text { Water Recovery } \\
\text { (M bls) }\end{array}$ \\
\hline Average & 1,360 & 40 & 0.37 & 270 \\
\hline High & 1,460 & 60 & 0.58 & 410 \\
\hline Low & 960 & 25 & 0.16 & 170 \\
\hline
\end{tabular}

- Wall. The Wall coal seam defines the top of the lower group of Fort Union Formation coals in Partition \#5. The Wall coal seam is stratigraphically below the Cook, separated by an average of 175 feet.

- $\quad$ Area. The Wall coal seam meets study inclusion criteria in 16 townships throughout the partition.

- $\quad$ Coal Thickness. The Cook seam coal thickness averages 33 feet, with a range of 20 to 45 feet.

- Coal Depth. The depth to the top of the Cook seam averages 1,500 feet, with a depth range of 1,220 to 1,900 .

- Development. The Wall coal seam is extensively developed in only one township in the southern portion of Partition \#5.

- $\quad$ Time Zero Well. Not available.

- $\quad$ Type Well. The history-matched Wall well in Partition \#4, adjusted for depth, gas content, permeability and coal thickness, serves as the type well for the Wall seam in Partition \#5.

Table 6-30. Wall Coal Seam

\begin{tabular}{|l|c|c|c|c|}
\hline \multicolumn{1}{|c|}{ Type Well } & $\begin{array}{c}\text { Well Depth } \\
\text { (ft) }\end{array}$ & $\begin{array}{c}\text { Coal Thickness } \\
\text { (ft) }\end{array}$ & $\begin{array}{c}\text { Cumulative Gas } \\
\text { Recovery } \\
\text { (Bcf) }\end{array}$ & $\begin{array}{c}\text { Cumulative } \\
\text { Water Recovery } \\
\text { (M bls) }\end{array}$ \\
\hline Average & 1,530 & 33 & 0.31 & 560 \\
\hline High & 1,520 & 45 & 0.39 & 760 \\
\hline Low & 1,470 & 20 & 0.18 & 340 \\
\hline
\end{tabular}

- Pawnee. The Pawnee coal seam is stratigraphically below the Wall, separated by an average of 215 feet. 
- $\quad$ Area. The Pawnee coal seam meets study inclusion criteria in 18 townships throughout the central and northern portions of the partition.

- Coal Thickness. The Pawnee seam coal thickness averages 41 feet, with a range of 25 to 70 feet.

- Coal Depth. The depth to the top of the Pawnee seam averages 1,710 feet, with a depth range of 1,350 to 2,260 .

- Development. A total of 368 drilled or permitted Pawnee CBM wells, concentrated in a handful of townships, exist in Partition \#5.

- $\quad$ Time Zero Well. Not available.

- Type Well. The history-matched Pawnee well in Partition \#8, adjusted for depth, gas content, permeability and coal thickness, serves as the Pawnee type well for Partition \#5.

Table 6-31. Pawnee Coal Seam

\begin{tabular}{|l|c|c|c|c|}
\hline \multicolumn{1}{|c|}{ Type Well } & $\begin{array}{c}\text { Well Depth } \\
\text { (ft) }\end{array}$ & $\begin{array}{c}\text { Coal Thickness } \\
\text { (ft) }\end{array}$ & $\begin{array}{c}\text { Cumulative Gas } \\
\text { Recovery } \\
\text { (Bcf) }\end{array}$ & $\begin{array}{c}\text { Cumulative } \\
\text { Water Recovery } \\
\text { (M bls) }\end{array}$ \\
\hline Average & 1,750 & 41 & 0.45 & 540 \\
\hline High & 1,470 & 70 & 0.64 & 920 \\
\hline Low & 1,580 & 25 & 0.25 & 330 \\
\hline
\end{tabular}

- $\quad$ Cache. The Cache coal seam is the basal unit of the lower group of Fort Union coals in Partition \#5. The Cache seam is stratigraphically below the Pawnee, separated by approximately 300 feet of section.

- $\quad$ Area. The Cache coal seam meets study inclusion criteria in 14 townships throughout the central and northern portions of the partition.

- Coal Thickness. The Cache seam coal thickness averages 32 feet, with a range of 20 to 50 feet.

- Coal Depth. The depth to the top of the Cache seam averages 2,020 feet, with a depth range of 1,510 to 2,350 .

- Development. The Cache coal seam is essentially undeveloped.

- $\quad$ Time Zero Well. Not available. 
- $\quad$ Type Well. The history-matched Pawnee well in Partition \#8, adjusted for depth, gas content, permeability and coal thickness, serves as the Cache type well for Partition \#5.

Table 6-32. Cache Coal Seam

\begin{tabular}{|l|c|c|c|c|}
\hline \multicolumn{1}{|c|}{ Type Well } & $\begin{array}{c}\text { Well Depth } \\
\text { (ft) }\end{array}$ & $\begin{array}{c}\text { Coal Thickness } \\
\text { (ft) }\end{array}$ & $\begin{array}{c}\text { Cumulative Gas } \\
\text { Recovery } \\
\text { (Bcf) }\end{array}$ & $\begin{array}{c}\text { Cumulative } \\
\text { Water Recovery } \\
\text { (M bls) }\end{array}$ \\
\hline Average & 2,050 & 32 & 0.34 & 420 \\
\hline High & 1,910 & 50 & 0.50 & 660 \\
\hline Low & 2,220 & 20 & 0.14 & 260 \\
\hline
\end{tabular}

Table 6-33. In-Place and Technically Recoverable CBM, Partition \#5

\begin{tabular}{|l||r|r|r|r||r|r|}
\hline Coal Seam & $\begin{array}{c}\text { No. Full } \\
\text { Townships }\end{array}$ & $\begin{array}{c}\text { Average } \\
\text { Depth } \\
\text { (ft) }\end{array}$ & $\begin{array}{c}\text { Average } \\
\text { Thickness } \\
\text { (ft) }\end{array}$ & $\begin{array}{c}\text { Average } \\
\text { Gas Content } \\
\text { (cf/ton) }\end{array}$ & $\begin{array}{r}\text { Gas In } \\
\text { Place } \\
\text { (Bcf) }\end{array}$ & $\begin{array}{c}\text { Technically } \\
\text { Recoverable } \\
\text { (Bcf) }\end{array}$ \\
\hline Felix & 4 & 530 & 24 & 46 & 180 & 140 \\
\hline Roland & 2 & 540 & 25 & 70 & 2,310 & 80 \\
\hline Smith & 18 & 820 & 39 & 63 & 220 & 1,560 \\
\hline Swartz & 2 & 740 & 43 & 86 & 1,180 & 180 \\
\hline Anderson & 9 & 1030 & 38 & 88 & 2,320 & 830 \\
\hline Canyon & 16 & 1060 & 39 & 107 & 6,760 & 1,500 \\
\hline Big George & 16 & 1280 & 97 & 85 & 250 & 3,510 \\
\hline Wyodak & 2 & 1000 & 73 & 109 & 3,060 & 210 \\
\hline Cook & 17 & 1320 & 40 & 120 & 2,250 & 1,810 \\
\hline Wall & 16 & 1500 & 32 & 137 & 4,000 & 1,350 \\
\hline Pawnee & 18 & 1710 & 41 & 159 & 2,700 & 2,320 \\
\hline Cache & 14 & 2020 & 32 & 101 & 180 & 1,320 \\
\hline Wildcat & 1 & 2190 & 45 & & 25,510 & 90 \\
\hline Totals & & & & & 14,910 \\
\hline
\end{tabular}

* To top of coal

\subsection{Partition \#6}

\subsubsection{Summary}

The main features of Partition \#6, in the western portion of the Powder River Basin, are as follows:

- The partition covers a 31-township area in the west-central portion of the PRB, from $45 \mathrm{~N}$ to $52 \mathrm{~N}$ and from $78 \mathrm{~W}$ to $80 \mathrm{~W}$ in the south and $78 \mathrm{~W}$ to $82 \mathrm{~W}$ in the north, Figure $6-36$. 


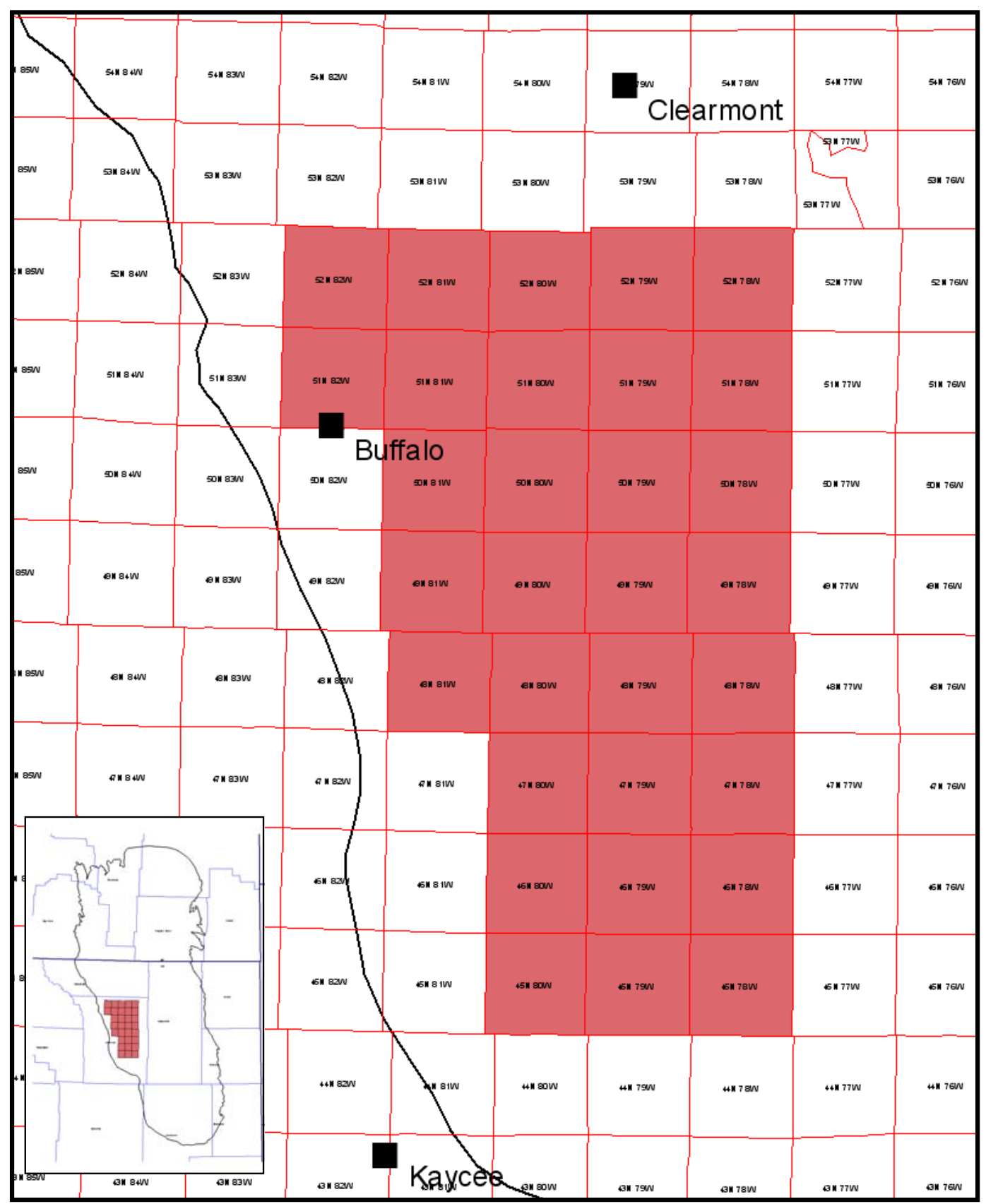

Figure 6-36. Partition \#6 Base Map 
- $\quad$ Partition \#5 contains 12 major coal seams in the Wasatch and Fort Union Formations. The depth to these coals ranges from 560 to 2,900 feet, with coal seam thickness ranging from 20 to 100 feet (township level averages). The gas in place in the partition is 6.2 Tcf, with technically recoverable gas of 3,460 Bcf. The results, by coal seam, are provided in Table 6-45.

\subsubsection{Discussion of Major Seams}

- Cameron. The first major coal seam in Partition \#6 is the Cameron. The Cameron is separated from the underlying Murry seam by an average of 100 feet of section.

- $\quad$ Area. The Cameron coal seam meets study inclusion criteria in one township in the northwestern portion of the partition.

- Coal Thickness. The Cameron seam coal thickness averages 20 feet.

- Coal Depth. The depth to the top of the Cameron seam averages 700 feet.

- Development. The Cameron coal seam is essentially undeveloped in Partition \#6.

- $\quad$ Time Zero Plot. Not available.

- $\quad$ Type Well. After adjustment for depth, gas content, permeability and coal thickness, the type well for the Smith coal seam in Partition \#5 serves as the type well for the Cameron coal seam.

Table 6-34. Cameron Coal Seam

\begin{tabular}{|l|c|c|c|c|}
\hline Type Well & $\begin{array}{c}\text { Well Depth } \\
\text { (ft) }\end{array}$ & $\begin{array}{c}\text { Coal Thickness } \\
\text { (ft) }\end{array}$ & $\begin{array}{c}\text { Cumulative Gas } \\
\text { Recovery } \\
\text { (Bcf) }\end{array}$ & $\begin{array}{c}\text { Cumulative } \\
\text { Water Recovery } \\
\text { (M bls) }\end{array}$ \\
\hline Average & 720 & 20 & 0.14 & 80 \\
\hline
\end{tabular}

- Murry. The Murry seam is stratigraphically below the Cameron coal seam. Due to stratigraphic proximity, separation of these seams is difficult outside of the northwestern portion of the partition.

- $\quad$ Area. The Murry coal seam meets study inclusion criteria in one township located in the northwestern portion of the partition.

- Coal Thickness. The Murry coal seam thickness averages 50 feet.

- Coal Depth. The depth to the top of the Murry seam averages 800 feet.

- Development. The Murry seam is essentially undeveloped in Partition \#6.

- $\quad$ Time Zero Plot. Not available 
- $\quad$ Type Well. After adjustment for depth, gas content, permeability and coal thickness, the type well for the Smith coal seam in Partition \#5 serves as the type well for the Murry coal seam.

Table 6-35. Murry Coal Seam

\begin{tabular}{|l|c|c|c|c|}
\hline Type Well & $\begin{array}{c}\text { Well Depth } \\
\text { (ft) }\end{array}$ & $\begin{array}{c}\text { Coal Thickness } \\
\text { (ft) }\end{array}$ & $\begin{array}{c}\text { Cumulative Gas } \\
\text { Recovery } \\
\text { (Bcf) }\end{array}$ & $\begin{array}{c}\text { Cumulative } \\
\text { Water Recovery } \\
\text { (M bls) }\end{array}$ \\
\hline Average & 850 & 50 & 0.40 & 190 \\
\hline
\end{tabular}

- Felix. The Felix coal seam lies stratigraphically below the Cameron and Murry seams.

- $\quad$ Area. The Felix coal seam meets study inclusion criteria in one township located in the northwestern portion of the partition.

- Coal Thickness. The Felix seam coal thickness averages 30 feet.

- Coal Depth. The depth to the top of the Felix seam averages 750 feet.

- Development. The Felix seam is essentially undeveloped in Partition \#6.

- $\quad$ Time Zero Plot. Not available.

- $\quad$ Type Well. After adjustment for depth, gas content, permeability and coal thickness, the type well for the Smith coal seam in Partition \#5 serves as the type well for the Felix coal seam.

Table 6-36. Felix Coal Seam

\begin{tabular}{|l|c|c|c|c|}
\hline Type Well & $\begin{array}{c}\text { Well Depth } \\
\text { (ft) }\end{array}$ & $\begin{array}{c}\text { Coal Thickness } \\
\text { (ft) }\end{array}$ & $\begin{array}{c}\text { Cumulative Gas } \\
\text { Recovery } \\
\text { (Bcf) }\end{array}$ & $\begin{array}{c}\text { Cumulative } \\
\text { Water Recovery } \\
\text { (M bls) }\end{array}$ \\
\hline Average & 780 & 30 & 0.22 & 120 \\
\hline
\end{tabular}

- Ucross. The Ucross coal seam is often difficult to distinguish from the overlying Cameron, Murry, and Felix seams.

- $\quad$ Area. The Ucross coal seam meets study inclusion criteria in 3 townships in the northwestern portion of the partition.

- Coal Thickness. The Ucross seam coal thickness averages 23 feet, with a range of 20 to 25 feet.

- $\quad$ Coal Depth. The depth to the top of the Ucross seam averages 790 feet, with a depth range of 560 to 950 feet. 
- Development. A small number of Ucross coal seams exist in one of the townships in Partition \#6.

- $\quad$ Time Zero Well. Not available.

- $\quad$ Type Well. The history-matched Smith well in Partition \#5, adjusted for depth, gas content, permeability and coal thickness, serves as the Ucross type well in this partition.

Table 6-37. Ucross Coal Seam

\begin{tabular}{|l|c|c|c|c|}
\hline Type Well & $\begin{array}{c}\text { Well Depth } \\
\text { (ft) }\end{array}$ & $\begin{array}{c}\text { Coal Thickness } \\
\text { (ft) }\end{array}$ & $\begin{array}{c}\text { Cumulative Gas } \\
\text { Recovery } \\
\text { (Bcf) }\end{array}$ & $\begin{array}{c}\text { Cumulative } \\
\text { Water Recovery } \\
\text { (M bls) }\end{array}$ \\
\hline Average & 810 & 23 & 0.18 & 90 \\
\hline
\end{tabular}

- Roland. The Roland is the uppermost Fort Union coal seam in Partition \#6.

- $\quad$ Area. The Roland coal seam meets study inclusion criteria in 5 townships in the northern portion of the partition.

- Coal Thickness. The Roland seam coal thickness averages 21 feet, with a range of 20 to 25 feet.

- Coal Depth. The depth to the top of the Roland seam averages 1,060 feet, with a depth range of 830 to 1,480 feet.

- Development. The are a total of 107 drilled or permitted Roland CBM wells in two of the townships in Partition \#6.

- $\quad$ Time Zero Plot. Not available.

- $\quad$ Type Well. The history-matched Smith well in Partition \#5, adjusted for depth, gas content, permeability and coal thickness, serves as the Roland type well in this partition.

Table 6-38. Roland Coal Seam

\begin{tabular}{|l|c|c|c|c|}
\hline \multicolumn{1}{|c|}{ Type Well } & $\begin{array}{c}\text { Well Depth } \\
\text { (ft) }\end{array}$ & $\begin{array}{c}\text { Coal Thickness } \\
\text { (ft) }\end{array}$ & $\begin{array}{c}\text { Cumulative Gas } \\
\text { Recovery } \\
\text { (Bcf) }\end{array}$ & $\begin{array}{c}\text { Cumulative } \\
\text { Water Recovery } \\
\text { (M bls) }\end{array}$ \\
\hline Average & 1,080 & 21 & 0.16 & 80 \\
\hline
\end{tabular}

- Anderson. The Anderson coal seam is thin and relatively undeveloped in Partition \#6.

- $\quad$ Area. The Anderson coal seam meets study inclusion criteria in 3 townships in the central portion of the partition. 
- Coal Thickness. The Anderson seam coal thickness averages 30 feet, with a range of 20 to 40 feet.

- Coal Depth. The depth to the top of the Anderson seam averages 1,220 feet, with a depth range of 1,030 to 1,480 feet.

- Development. The Anderson coal seam is undeveloped in Partition \#6.

- $\quad$ Time Zero Plot. Not available.

- $\quad$ Type Well. The history-matched Anderson well in Partition \#8, adjusted for depth, gas content, permeability and coal thickness, serves as the Anderson type well for Partition \#6.

Table 6-39. Anderson Coal Seam

\begin{tabular}{|l|c|c|c|c|}
\hline Type Well & $\begin{array}{c}\text { Well Depth } \\
\text { (ft) }\end{array}$ & $\begin{array}{c}\text { Coal Thickness } \\
\text { (ft) }\end{array}$ & $\begin{array}{c}\text { Cumulative Gas } \\
\text { Recovery } \\
\text { (Bcf) }\end{array}$ & $\begin{array}{c}\text { Cumulative } \\
\text { Water Recovery } \\
\text { (M bls) }\end{array}$ \\
\hline Average & 1,250 & 30 & 0.26 & 80 \\
\hline
\end{tabular}

- Canyon. The Canyon seam in Partition \#6 is approximately 300 feet deeper than the overlying Anderson seam.

- $\quad$ Area. The Canyon coal seam meets study inclusion criteria in 8 townships throughout the partition.

- Coal Thickness. The Canyon seam coal thickness averages 30 feet, with a range of 20 to 50 feet.

- Coal Depth. The depth to the top of the Canyon seam averages 1,520 feet, with a depth range of 1,300 to 1,720 feet.

- Development. The Canyon coal seam is undeveloped in Partition \#6.

- $\quad$ Time Zero Well. Not available.

- $\quad$ Type Well. The history-matched Canyon well in Partition \#4, adjusted for depth, gas content, permeability and coal thickness, serves as the Canyon type well for Partition \#6.

Table 6-40. Canyon Coal Seam

\begin{tabular}{|l|c|c|c|c|}
\hline Type Well & $\begin{array}{c}\text { Well Depth } \\
\text { (ft) }\end{array}$ & $\begin{array}{c}\text { Coal Thickness } \\
\text { (ft) }\end{array}$ & $\begin{array}{c}\text { Cumulative Gas } \\
\text { Recovery } \\
\text { (Bcf) }\end{array}$ & $\begin{array}{c}\text { Cumulative } \\
\text { Water Recovery } \\
\text { (M bls) }\end{array}$ \\
\hline Average & 1,550 & 30 & 0.32 & 230 \\
\hline
\end{tabular}




\begin{tabular}{|l|l|l|l|l|}
\hline High & 1,600 & 50 & 0.27 & 190 \\
\hline Low & 1,740 & 20 & 0.24 & 150 \\
\hline
\end{tabular}

- Big George. Stratigraphically equivalent to the Anderson and Canyon coals, the Big George seam exists in areas where these two coals merge.

- $\quad$ Area. The Big George coal seam meets study inclusion criteria in 2 townships in the southeastern portion of the partition.

- Coal Thickness. The Big George seam coal thickness averages 85 feet, with a range of 70 to 100 feet.

- Coal Depth. The depth to the top of the Big George seam averages 1,665 feet, with a depth range of 1,630 to 1,700 feet.

- Development. The Big George coal seam is essentially undeveloped in Partition \#6.

- $\quad$ Time Zero Well. Not available.

- $\quad$ Type Well. The history-matched Big George well in Partition \#3, adjusted for depth, gas content, permeability and coal thickness, serves as the Big George type well for Partition \#6.

Table 6-41. Big George Coal Seam

\begin{tabular}{|l|c|c|c|c|}
\hline Type Well & $\begin{array}{c}\text { Well Depth } \\
\text { (ft) }\end{array}$ & $\begin{array}{c}\text { Coal Thickness } \\
\text { (ft) }\end{array}$ & $\begin{array}{c}\text { Cumulative Gas } \\
\text { Recovery } \\
\text { (Bcf) }\end{array}$ & $\begin{array}{c}\text { Cumulative } \\
\text { Water Recovery } \\
\text { (M bls) }\end{array}$ \\
\hline Average & 1,750 & 85 & 0.85 & 660 \\
\hline
\end{tabular}

- Cook. The Cook seam defines the base of the upper group of Fort Union coals in Partition \#6. The proximity of the Cook seam to the basal boundary of the Canyon and equivalents poses correlation problems.

- $\quad$ Area. The Cook coal seam meets study inclusion criteria in 2 townships along the eastern edge of the partition.

- Coal Thickness. The Cook seam coal thickness averages 58 feet, with a range of 25 to 90 feet.

- Coal Depth. The depth to the top of the Cook seam averages 1,863 feet, with a depth range of 1,850 to 1,875 feet.

- Development. The Cook seam is essentially undeveloped in Partition \#6. 
- $\quad$ Time Zero Well. Not available.

- $\quad$ Type Well. The history-matched Cook well in Partition \#8, adjusted for depth, gas content, permeability and coal thickness, serves as the Cook type well for Partition \#6.

Table 6-42. Cook Coal Seam

\begin{tabular}{|l|c|c|c|c|}
\hline Type Well & $\begin{array}{c}\text { Well Depth } \\
\text { (ft) }\end{array}$ & $\begin{array}{c}\text { Coal Thickness } \\
\text { (ft) }\end{array}$ & $\begin{array}{c}\text { Cumulative Gas } \\
\text { Recovery } \\
\text { (Bcf) }\end{array}$ & $\begin{array}{c}\text { Cumulative } \\
\text { Water Recovery } \\
\text { (M bls) }\end{array}$ \\
\hline Average & 1,920 & 58 & 0.66 & 390 \\
\hline
\end{tabular}

- Wall. The Wall coal seam defines the top of the lower group of Fort Union Formation coals in Partition \#6.

- $\quad$ Area. The Wall coal seam meets study inclusion criteria in one township in the northeastern portion of the partition.

- Coal Thickness. The Cook seam coal thickness averages 40 feet.

- Coal Depth. The depth to the top of the Cook seam averages 1,630 feet.

- Development. The are no Wall CBM wells drilled in Partition \#6.

- $\quad$ Time Zero Well. Not available.

- $\quad$ Type Well. The history-matched Wall well in Partition \#8, adjusted for depth, gas content, permeability and coal thickness, serves as the type well for the Wall seam in Partition \#6.

Table 6-43. Wall Coal Seam

\begin{tabular}{|l|c|c|c|c|}
\hline Type Well & $\begin{array}{c}\text { Well Depth } \\
\text { (ft) }\end{array}$ & $\begin{array}{c}\text { Coal Thickness } \\
\text { (ft) }\end{array}$ & $\begin{array}{c}\text { Cumulative Gas } \\
\text { Recovery } \\
\text { (Bcf) }\end{array}$ & $\begin{array}{c}\text { Cumulative } \\
\text { Water Recovery } \\
\text { (M bls) }\end{array}$ \\
\hline Average & 1,670 & 40 & 0.38 & 520 \\
\hline
\end{tabular}

- Pawnee. The Pawnee coal seam is stratigraphically below the Wall, separated by an average interval of 365 feet.

- $\quad$ Area. The Pawnee coal seam meets study inclusion criteria in 4 townships in the north-central portion of the partition.

- Coal Thickness. The Pawnee seam coal thickness averages 44 feet, with a range of 20 to 100 feet. 
- Coal Depth. The depth to the top of the Pawnee seam averages 2,000 feet, with a depth range of 1,730 to 2,270 feet.

- Development. The Pawnee coal seam is essentially undeveloped in Partition \#6.

- $\quad$ Time Zero Well. Not available.

- Type Well. The history-matched Pawnee well in Partition \#8, adjusted for depth, gas content, permeability and coal thickness, serves as the Pawnee type well for Partition \#6.

Table 6-44. Pawnee Coal Seam

\begin{tabular}{|l|c|c|c|c|}
\hline \multicolumn{1}{|c|}{ Type Well } & $\begin{array}{c}\text { Well Depth } \\
\text { (ft) }\end{array}$ & $\begin{array}{c}\text { Coal Thickness } \\
\text { (ft) }\end{array}$ & $\begin{array}{c}\text { Cumulative Gas } \\
\text { Recovery } \\
\text { (Bcf) }\end{array}$ & $\begin{array}{c}\text { Cumulative } \\
\text { Water Recovery } \\
\text { (M bls) }\end{array}$ \\
\hline Average & 2,040 & 44 & 0.47 & 580 \\
\hline High & 2,000 & 100 & 1.05 & 1,320 \\
\hline Low & 1,750 & 20 & 0.19 & 260 \\
\hline
\end{tabular}

Table 6-45. In-Place and Technically Recoverable CBM, Partition \#6

\begin{tabular}{|c|c|c|c|c|c|c|}
\hline Coal Seam & $\begin{array}{c}\text { No. Full } \\
\text { Townships }\end{array}$ & $\begin{array}{c}\text { Average } \\
\text { Depth } \\
\text { (ft)* }\end{array}$ & $\begin{array}{c}\text { Average } \\
\text { Thickness } \\
\text { (ft) }\end{array}$ & $\begin{array}{c}\text { Average } \\
\text { Gas Content } \\
\text { (cf/ton) }\end{array}$ & $\begin{array}{c}\text { Gas In } \\
\text { Place } \\
\text { (Bcf) }\end{array}$ & $\begin{array}{c}\text { Technically } \\
\text { Recoverable } \\
\text { (Bcf) }\end{array}$ \\
\hline Cameron & 1 & 700 & 20 & 60 & 50 & 40 \\
\hline Felix & 1 & 750 & 30 & 63 & 140 & 110 \\
\hline Murry & 1 & 800 & 50 & 69 & 80 & 60 \\
\hline Ucross & 3 & 790 & 23 & 66 & 190 & 150 \\
\hline Roland & 5 & 1,060 & 21 & 86 & 370 & 240 \\
\hline Anderson & 3 & 1,220 & 30 & 99 & 370 & 220 \\
\hline Canyon & 8 & 1,520 & 30 & 123 & 1,090 & 660 \\
\hline Big George & 2 & 1,670 & 85 & 136 & 930 & 490 \\
\hline Cook & 2 & 1,860 & 58 & 147 & 690 & 380 \\
\hline Wall & 1 & 1,630 & 40 & 130 & 200 & 110 \\
\hline Pawnee & 4 & 2,000 & 44 & 158 & 1,270 & 620 \\
\hline Wildcat & 4 & 2,640 & 25 & 191 & 760 & 370 \\
\hline Totals & & & & & 6,150 & 3,460 \\
\hline
\end{tabular}

* To top of coal

\subsection{Partition \#7}

\subsubsection{Summary}

The main features of Partition \#7, in the northern Wyoming portion of the Powder River Basin, are as follows: 
- $\quad$ The partition covers a 23-township area in the northwestern portion of the PRB, from $53 \mathrm{~N}$ to $58 \mathrm{~N}$ and from $78 \mathrm{~W}$ to $82 \mathrm{~W}$, Figure $6-37$.

- $\quad$ Partition \#7 contains 9 major coal seams in the Wasatch and Fort Union Formations. The depth to these coals ranges from about 390 to 2,980 feet, with coal seam thickness ranging from 20 to 40 feet (township level averages). The gas in place in the partition is $2.8 \mathrm{Tcf}$, with technically recoverable gas of $1,680 \mathrm{Bcf}$. The results, by coal seam, are provided in Table 6-55.

\subsubsection{Discussion of Major Seams}

- Wasatch. The shallowest major coal seam in Partition \#7 is the Wasatch that combines the Felix and Ucross seams. The Wasatch is separated from the underlying Roland seam by an average of 280 feet of section.

- $\quad$ Area. The Wasatch coal seam meets study inclusion criteria in 6 townships located in the southern portion of the partition.

- Coal Thickness. The Wasatch seam coal thickness averages 25 feet, with a range of 20 to 34 feet.

- Coal Depth. The depth to the top of the Wasatch seam averages 540 feet, with a range of 390 to 730 feet.

- Development. The are a total of 124 drilled or permitted Wasatch CBM wells in Partition \#7.

- $\quad$ Time Zero Plot. Not available.

- $\quad$ Type Well. After adjustment for depth, gas content, permeability and coal thickness, the type well for the Smith coal seam in Partition \#5 serves as the type well for the Wasatch coal seam in this partition. 


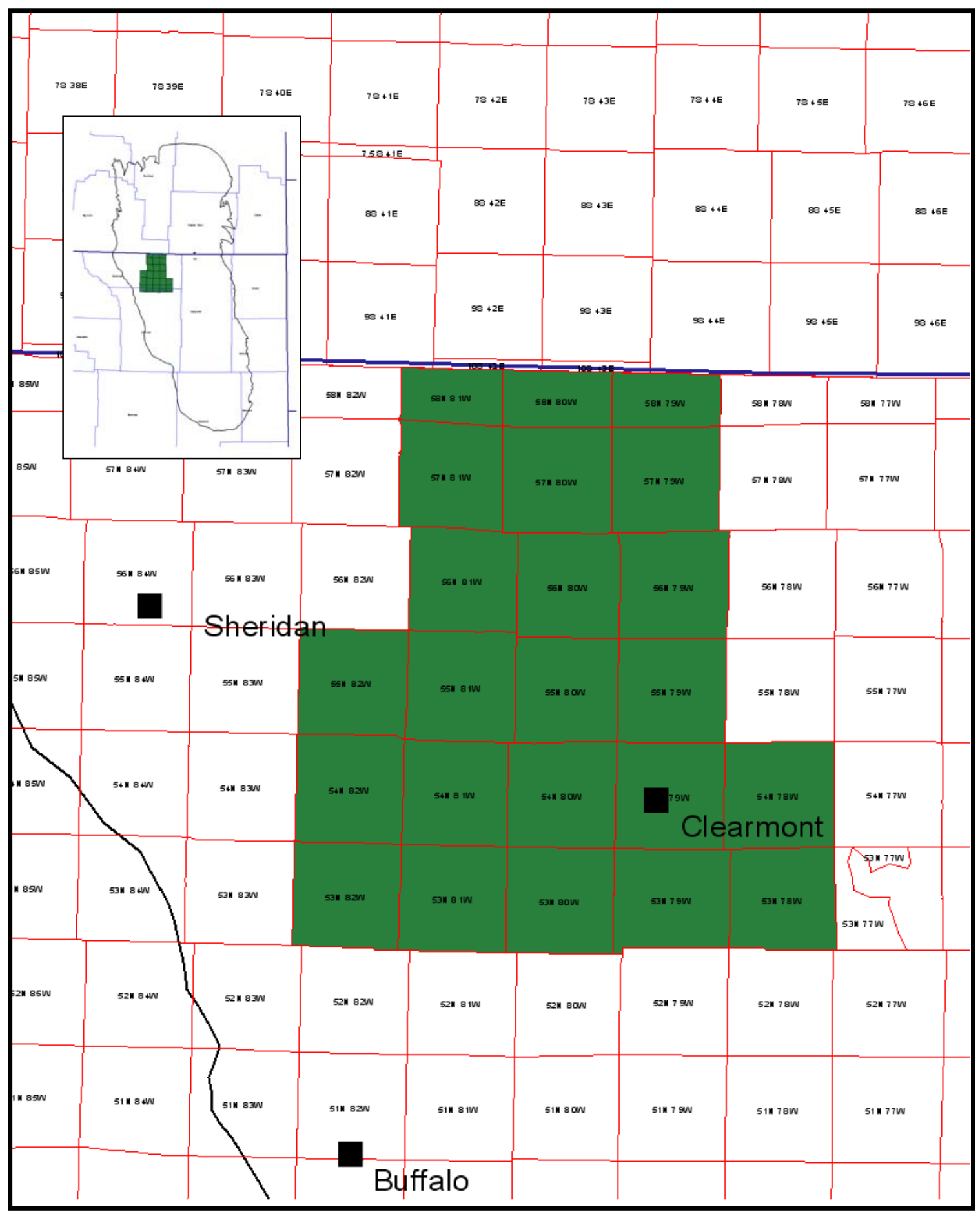

Figure 6-37. Partition \#7 Base Map 
Table 6-46. Wasatch Coal Seam

\begin{tabular}{|l|c|c|c|c|}
\hline \multicolumn{1}{|c|}{ Type Well } & $\begin{array}{c}\text { Well Depth } \\
\text { (ft) }\end{array}$ & $\begin{array}{c}\text { Coal Thickness } \\
\text { (ft) }\end{array}$ & $\begin{array}{c}\text { Cumulative Gas } \\
\text { Recovery } \\
\text { (Bcf) }\end{array}$ & $\begin{array}{c}\text { Cumulative } \\
\text { Water Recovery } \\
\text { (M bls) }\end{array}$ \\
\hline Average & 570 & 25 & 0.13 & 100 \\
\hline High & 620 & 34 & 0.19 & 130 \\
\hline Low & 420 & 20 & 0.08 & 80 \\
\hline
\end{tabular}

- Roland. The Roland seam lies stratigraphically below the Wasatch and is the first Fort Union coal seam in this partition.

- $\quad$ Area. The Roland coal seam meets study inclusion criteria in 3 township located in the southern portion of the partition.

- Coal Thickness. The Roland seam coal thickness averages 27 feet, with a range of 20 to 40 feet.

- Coal Depth. The depth to the top of the Roland seam averages 820 feet, with a range of 800 to 850 feet.

- Development. The are a total of 169 drilled or permitted Roland CBM wells in Partition \#7.

- $\quad$ Time Zero Plot. Not available.

- $\quad$ Type Well. After adjustment for depth, gas content, permeability and coal thickness, the type well for the Smith coal seam in Partition \#5 serves as the type well for the Roland coal seam in this partition.

Table 6-47. Roland Coal Seam

\begin{tabular}{|l|c|c|c|c|}
\hline \multicolumn{1}{|c|}{ Type Well } & $\begin{array}{c}\text { Well Depth } \\
\text { (ft) }\end{array}$ & $\begin{array}{c}\text { Coal Thickness } \\
\text { (ft) }\end{array}$ & $\begin{array}{c}\text { Cumulative Gas } \\
\text { Recovery } \\
\text { (Bcf) }\end{array}$ & $\begin{array}{c}\text { Cumulative } \\
\text { Water Recovery } \\
\text { (M bls) }\end{array}$ \\
\hline Average & 850 & 27 & 0.21 & 100 \\
\hline High & 840 & 40 & 0.31 & 150 \\
\hline Low & 840 & 20 & 0.16 & 80 \\
\hline
\end{tabular}

- $\quad$ Smith. The Smith seam is stratigraphically below the Roland coal seam, separated by approximately 350 feet of section.

- $\quad$ Area. The Smith coal seam meets study inclusion criteria in two townships, located in the central portion of the partition.

- Coal Thickness. The Smith coal seam thickness averages 20 feet. 
- Coal Depth. The depth to the top of the Smith seam averages 1,180 feet, with a range of 1,065 to 1,300 feet.

- Development. The are a handful of Smith wells and permits in Partition \#7.

- $\quad$ Time Zero Plot. Not available

- $\quad$ Type Well. After adjustment for depth, gas content, permeability and coal thickness, the type well for the Smith coal seam in Partition \#5 serves as the type well for the Smith coal seam in this partition.

Table 6-48. Smith Coal Seam

\begin{tabular}{|l|c|c|c|c|}
\hline Type Well & $\begin{array}{c}\text { Well Depth } \\
\text { (ft) }\end{array}$ & $\begin{array}{c}\text { Coal Thickness } \\
\text { (ft) }\end{array}$ & $\begin{array}{c}\text { Cumulative Gas } \\
\text { Recovery } \\
\text { (Bcf) }\end{array}$ & $\begin{array}{c}\text { Cumulative } \\
\text { Water Recovery } \\
\text { (M bls) }\end{array}$ \\
\hline Average & 1,200 & 20 & 0.16 & 80 \\
\hline
\end{tabular}

- Anderson. The Anderson seam is stratigraphically below the Smith coal seam.

- $\quad$ Area. The Anderson coal seam meets study inclusion criteria in 5 townships, 4 of which lie in the northernmost portion of the partition.

- Coal Thickness. The Anderson seam coal thickness averages 21 feet, with a range of 20 to 25 feet.

- Coal Depth. The depth to the top of the Anderson seam averages 910 feet, with a depth range of 370 to 1,480 feet.

- Development. The Anderson coal seam is essentially undeveloped in Partition \#7.

- $\quad$ Time Zero Well. Not available.

- $\quad$ Type Well. The history-matched Anderson well in Partition \#8, adjusted for depth, gas content, permeability and coal thickness, serves as the Anderson type well in this partition.

Table 6-49. Anderson Coal Seam

\begin{tabular}{|l|c|c|c|c|}
\hline \multicolumn{1}{|c|}{ Type Well } & $\begin{array}{c}\text { Well Depth } \\
\text { (ft) }\end{array}$ & $\begin{array}{c}\text { Coal Thickness } \\
\text { (ft) }\end{array}$ & $\begin{array}{c}\text { Cumulative Gas } \\
\text { Recovery } \\
\text { (Bcf) }\end{array}$ & $\begin{array}{c}\text { Cumulative } \\
\text { Water Recovery } \\
\text { (M bls) }\end{array}$ \\
\hline Average & 930 & 21 & 0.16 & 60 \\
\hline High & 1,500 & 25 & 0.24 & 50 \\
\hline Low & 390 & 20 & 0.07 & 50 \\
\hline
\end{tabular}


- Canyon. The Canyon is about 600 feet below the Anderson.

- $\quad$ Area. The Canyon coal seam meets study inclusion criteria in two townships in the southern portion of the partition.

- Coal Thickness. The Canyon seam coal thickness averages 25 feet.

- Coal Depth. The depth to the top of the Canyon seam averages 1,500 feet, with a depth range of 1,450 to 1,540 feet.

- Development. The Canyon coal seam is undeveloped in Partition \#7.

- $\quad$ Time Zero Plot. Not available.

- Type Well. The history-matched Canyon well in Partition \#4, adjusted for depth, gas content, permeability and coal thickness, serves as the Canyon type well in this partition.

Table 6-50. Canyon Coal Seam

\begin{tabular}{|l|c|c|c|c|}
\hline Type Well & $\begin{array}{c}\text { Well Depth } \\
\text { (ft) }\end{array}$ & $\begin{array}{c}\text { Coal Thickness } \\
\text { (ft) }\end{array}$ & $\begin{array}{c}\text { Cumulative Gas } \\
\text { Recovery } \\
\text { (Bcf) }\end{array}$ & $\begin{array}{c}\text { Cumulative } \\
\text { Water Recovery } \\
\text { (M bls) }\end{array}$ \\
\hline Average & 1,520 & 25 & 0.26 & 190 \\
\hline
\end{tabular}

- Cook. The Cook seam is the next deepest coal in Partition \#7.

- $\quad$ Area. The Cook coal seam meets study inclusion criteria in two townships in the northern portion of the partition.

- Coal Thickness. The Cook seam coal thickness averages 28 feet, with a range of 25 to 30 feet.

- Coal Depth. The depth to the top of the Cook seam averages 2,300 feet, with a depth range of 2,250 to 2,350 feet.

- Development. The Cook coal seam is undeveloped in Partition \#7.

- $\quad$ Time Zero Plot. Not available.

- Type Well. The history-matched Cook well in Partition \#8, adjusted for depth, gas content, permeability and coal thickness, serves as the Cook type well for Partition \#7. 
Table 6-51. Cook Coal Seam

\begin{tabular}{|l|c|c|c|c|}
\hline Type Well & $\begin{array}{c}\text { Well Depth } \\
\text { (ft) }\end{array}$ & $\begin{array}{c}\text { Coal Thickness } \\
\text { (ft) }\end{array}$ & $\begin{array}{c}\text { Cumulative Gas } \\
\text { Recovery } \\
\text { (Bcf) }\end{array}$ & $\begin{array}{c}\text { Cumulative } \\
\text { Water Recovery } \\
\text { (M bls) }\end{array}$ \\
\hline Average & 2,330 & 28 & 0.36 & 190 \\
\hline
\end{tabular}

- Wall. The Wall coal underlies the Cook coal seam by 250 feet of section.

- $\quad$ Area. The Wall coal seam meets study inclusion criteria in one township in the northern portion of the partition.

- Coal Thickness. The Wall seam coal thickness averages 30 feet.

- Coal Depth. The depth to the top of the Wall seam averages 2,500 feet.

- Development. Wall coal seam is undeveloped in Partition \#7.

- $\quad$ Time Zero Well. Not available.

- $\quad$ Type Well. The history-matched Wall well in Partition \#8, adjusted for depth, gas content, permeability and coal thickness, serves as the Wall type well for Partition \#7:

Table 6-52. Wall Coal Seam

\begin{tabular}{|l|c|c|c|c|}
\hline \multicolumn{1}{|c|}{ Type Well } & $\begin{array}{c}\text { Well Depth } \\
\text { (ft) }\end{array}$ & $\begin{array}{c}\text { Coal Thickness } \\
\text { (ft) }\end{array}$ & $\begin{array}{c}\text { Cumulative Gas } \\
\text { Recovery } \\
\text { (Bcf) }\end{array}$ & $\begin{array}{c}\text { Cumulative } \\
\text { Water Recovery } \\
\text { (M bls) }\end{array}$ \\
\hline Average & 2,530 & 30 & 0.36 & 390 \\
\hline
\end{tabular}

- Pawnee. The Pawnee coal seam underlies the Wall coal in this partition.

- $\quad$ Area. The Pawnee coal seam meets study inclusion criteria in one township in the southeastern portion of the partition.

- $\quad$ Coal Thickness. The Pawnee seam coal thickness averages 40 feet.

- Coal Depth. The depth to the top of the Pawnee seam averages 2,050 feet.

- Development. The Pawnee coal seam is undeveloped in Partition \#7.

- $\quad$ Time Zero Well. Not available.

- Type Well. The history-matched Pawnee well in Partition \#8, adjusted for depth, gas content, permeability and coal thickness, serves as the Pawnee type well for this partition. 
Table 6-53. Pawnee Coal Seam

\begin{tabular}{|l|c|c|c|c|}
\hline \multicolumn{1}{|c|}{ Type Well } & $\begin{array}{c}\text { Well Depth } \\
\text { (ft) }\end{array}$ & $\begin{array}{c}\text { Coal Thickness } \\
\text { (ft) }\end{array}$ & $\begin{array}{c}\text { Cumulative Gas } \\
\text { Recovery } \\
\text { (Bcf) }\end{array}$ & $\begin{array}{c}\text { Cumulative } \\
\text { Water Recovery } \\
\text { (M bls) }\end{array}$ \\
\hline Average & 2,090 & 40 & 0.47 & 530 \\
\hline
\end{tabular}

- $\quad$ Cache. The Cache seam is the deepest major coal seam, both stratigraphically and structurally, in Partition \#7. It is nearly 600 feet below the Pawnee seam.

- $\quad$ Area. The Cache coal seam meets study inclusion criteria in 3 townships in the northern and central portions of the partition.

- Coal Thickness. The Cache seam coal thickness averages 30 feet in each of the 3 townships.

- Coal Depth. The depth to the top of the Cache seam averages 2,623 feet, with a depth range of 2,200 to 2,980 feet.

- Development. The Cache coal seam is undeveloped in Partition \#7.

- $\quad$ Time Zero Well. Not available.

- Type Well. The history-matched Cache well in Partition \#8, adjusted for depth, gas content, permeability and coal thickness, serves as the Cache type well for Partition \#7:

Table 6-54. Cache Coal Seam

\begin{tabular}{|l|c|c|c|c|}
\hline \multicolumn{1}{|c|}{ Type Well } & $\begin{array}{c}\text { Well Depth } \\
\text { (ft) }\end{array}$ & $\begin{array}{c}\text { Coal Thickness } \\
\text { (ft) }\end{array}$ & $\begin{array}{c}\text { Cumulative Gas } \\
\text { Recovery } \\
\text { (Bcf) }\end{array}$ & $\begin{array}{c}\text { Cumulative } \\
\text { Water Recovery } \\
\text { (M bls) }\end{array}$ \\
\hline Average & 2,650 & 30 & 0.38 & 400 \\
\hline
\end{tabular}


Table 6-55. In-Place and Technically Recoverable CBM, Partition \#7

\begin{tabular}{|l||r|r|r|r||r|r|}
\hline Coal Seam & $\begin{array}{c}\text { No. Full } \\
\text { Townships }\end{array}$ & $\begin{array}{c}\text { Average } \\
\text { Depth } \\
\text { (ft) }\end{array}$ & $\begin{array}{c}\text { Average } \\
\text { Thickness } \\
\text { (ft) }\end{array}$ & $\begin{array}{c}\text { Average } \\
\text { Gas Content } \\
\text { (cf/ton) }\end{array}$ & $\begin{array}{c}\text { Gas In } \\
\text { Place } \\
\text { (Bcf) }\end{array}$ & $\begin{array}{c}\text { Technically } \\
\text { Recoverable } \\
\text { (Bcf) }\end{array}$ \\
\hline Wasatch & 6 & 540 & 25 & 47 & 290 & 230 \\
\hline Roland & 3 & 820 & 27 & 96 & 160 & 200 \\
\hline Smith & 2 & 1,180 & 20 & 75 & 320 & 90 \\
\hline Anderson & 5 & 910 & 21 & 120 & 250 & 230 \\
\hline Canyon & 2 & 1,500 & 25 & 178 & 400 & 150 \\
\hline Cook & 2 & 2,300 & 28 & 186 & 210 & 210 \\
\hline Wall & 1 & 2,500 & 30 & 160 & 250 & 100 \\
\hline Pawnee & 1 & 2,050 & 40 & 190 & 680 & 140 \\
\hline Cache & 3 & 2,623 & 30 & & 2,820 & 330 \\
\hline Totals & & & & & 1,680 \\
\hline
\end{tabular}

* To top of coal

\subsection{Partition \#8}

\subsubsection{Summary}

The main features of Partition \#8, in the Wyoming portion of the Powder River Basin, are as follows:

- The partition covers a 41-township area in the northeastern portion of the Powder River Basin, from $53 \mathrm{~N}$ to $58 \mathrm{~N}$ and from $72 \mathrm{~W}$ to $78 \mathrm{~W}$, Figure $6-38$.

- Partition \#8 contains 9 major coal seams in the Fort Union Formation. The depth of these coals ranges from about 300 to 2,770 feet, with coal seam thickness ranging from 20 to 85 feet (township level averages). The gas in place in the partition is $9.2 \mathrm{Tcf}$, with technically recoverable gas of 7,020 Bcf. The results, by coal seam, are provided in Table 6-64.

\subsubsection{Discussion of Major Seams}

- $\quad$ Smith. The Smith coal seam is the shallowest major coal seam in Partition \#8.

- $\quad$ Area. The Smith coal seam meets study inclusion criteria in 8 townships, most of which are located in the southern portion of Partition \#8.

- Coal Thickness. The Smith seam coal thickness averages 33 feet, with a range of 20 to 38 feet.

- Coal Depth. The depth to the top of the Smith seam averages 430 feet, with a range of 300 to 500 feet. 


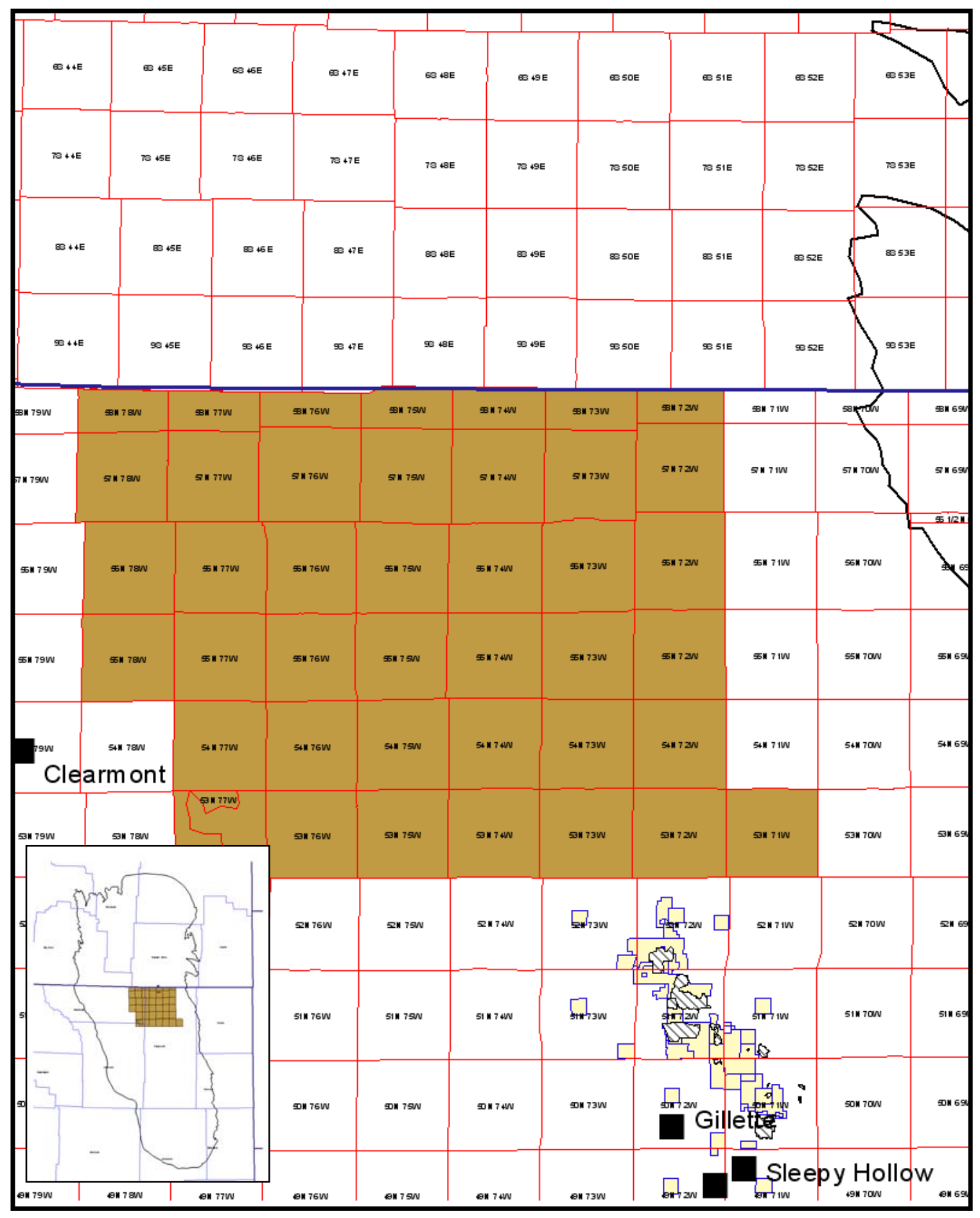

Figure 6-38. Partition \#8 Base Map 
- Development. The are a total of 66 drilled and permitted Smith CBM wells in Partition \#8.

- $\quad$ Time Zero Plot. Not available.

- $\quad$ Type Well. After adjustment for depth, gas content, permeability and coal thickness, the type well for the Smith coal seam in Partition \#5 serves as the type well for the Smith coal seam in this partition.

Table 6-56. Smith Coal Seam

\begin{tabular}{|l|c|c|c|c|}
\hline \multicolumn{1}{|c|}{ Type Well } & $\begin{array}{c}\text { Well Depth } \\
\text { (ft) }\end{array}$ & $\begin{array}{c}\text { Coal Thickness } \\
\text { (ft) }\end{array}$ & $\begin{array}{c}\text { Cumulative Gas } \\
\text { Recovery } \\
\text { (Bcf) }\end{array}$ & $\begin{array}{c}\text { Cumulative } \\
\text { Water Recovery } \\
\text { (M bls) }\end{array}$ \\
\hline Average & 460 & 33 & 0.15 & 130 \\
\hline High & 500 & 38 & 0.18 & 150 \\
\hline Low & 320 & 20 & 0.06 & 80 \\
\hline
\end{tabular}

- Swartz. The Swartz seam lies stratigraphically below the Smith seam, separated by an average of 150 feet of section.

- $\quad$ Area. The Swartz coal seam meets study inclusion criteria in 2 township located in the southern portion of the partition.

- $\quad$ Coal Thickness. The Swartz seam coal thickness averages 21 feet.

- $\quad$ Coal Depth. The depth to the top of the Swartz seam averages 580 feet.

- Development. The Swartz coal seam is undeveloped in Partition \#8.

- $\quad$ Time Zero Plot. Not available.

- $\quad$ Type Well. After adjustment for depth, gas content, permeability and coal thickness, the type well for the Smith coal seam in Partition \#5 serves as the type well for the Swartz coal seam in Partition \#8.

Table 6-57. Swartz Coal Seam

\begin{tabular}{|l|c|c|c|c|}
\hline \multicolumn{1}{|c|}{ Type Well } & $\begin{array}{c}\text { Well Depth } \\
\text { (ft) }\end{array}$ & $\begin{array}{c}\text { Coal Thickness } \\
\text { (ft) }\end{array}$ & $\begin{array}{c}\text { Cumulative Gas } \\
\text { Recovery } \\
\text { (Bcf) }\end{array}$ & $\begin{array}{c}\text { Cumulative } \\
\text { Water Recovery } \\
\text { (M bls) }\end{array}$ \\
\hline Average & 600 & 21 & 0.12 & 80 \\
\hline
\end{tabular}

- Anderson. The Anderson seam is often grouped with the underlying Canyon coal seam as the Wyodak coal. Close stratigraphic proximity with the Canyon makes recognition of the Anderson difficult in much of the partition. 
- $\quad$ Area. The Anderson coal seam meets study inclusion criteria in 9 townships located in the southern and central portions of the partition.

- Coal Thickness. The Anderson coal seam thickness averages 35 feet, with a range of 25 to 50 feet.

- Coal Depth. The depth to the top of the Anderson seam averages 600 feet, with a range of 400 to 900 feet.

- Development. The are a total of 532 drilled and permitted Anderson CBM wells in Partition \#8.

- $\quad$ Time Zero Plot. The time zero plot for 261 producing Anderson coal seam wells is provided in Figure 6-39. Initial water rates are 130 barrels per day declining to about 90 barrels per day after 1 year. Gas production begins immediately with an initial rate of $30 \mathrm{Mcfd}$. The gas rate peaks at $135 \mathrm{Mcfd}$ at the beginning of year 2 .

- $\quad$ Type Well. The history-matched type well for the Anderson coal seam is provided in Figure 6-40. After normalizing for coal thickness, depth and gas content, the estimated gas and water recoveries are as follows in the table below.

Table 6-58. Anderson Coal Seam

\begin{tabular}{|l|c|c|c|c|}
\hline \multicolumn{1}{|c|}{ Type Well } & $\begin{array}{c}\text { Well Depth } \\
\text { (ft) }\end{array}$ & $\begin{array}{c}\text { Coal Thickness } \\
\text { (ft) }\end{array}$ & $\begin{array}{c}\text { Cumulative Gas } \\
\text { Recovery } \\
\text { (Bcf) }\end{array}$ & $\begin{array}{c}\text { Cumulative } \\
\text { Water Recovery } \\
\text { (M bls) }\end{array}$ \\
\hline Average & 630 & 35 & 0.18 & 90 \\
\hline High & 710 & 50 & 0.29 & 130 \\
\hline Low & 630 & 25 & 0.13 & 70 \\
\hline
\end{tabular}

- Canyon. The Canyon seam is stratigraphically below the Anderson seam but is often difficult to distinctly identify.

- $\quad$ Area. The Canyon coal seam meets study inclusion criteria in 19 townships throughout the partition.

- Coal Thickness. The Canyon seam coal thickness averages 37 feet, with a range of 30 to 47 feet.

- Coal Depth. The depth to the top of the Canyon seam averages 620 feet, with a depth range of 300 to 950 feet.

- Development. The are a total of 1184 drilled and permitted Canyon CBM wells in this partition.

- $\quad$ Time Zero Well. Not available. 


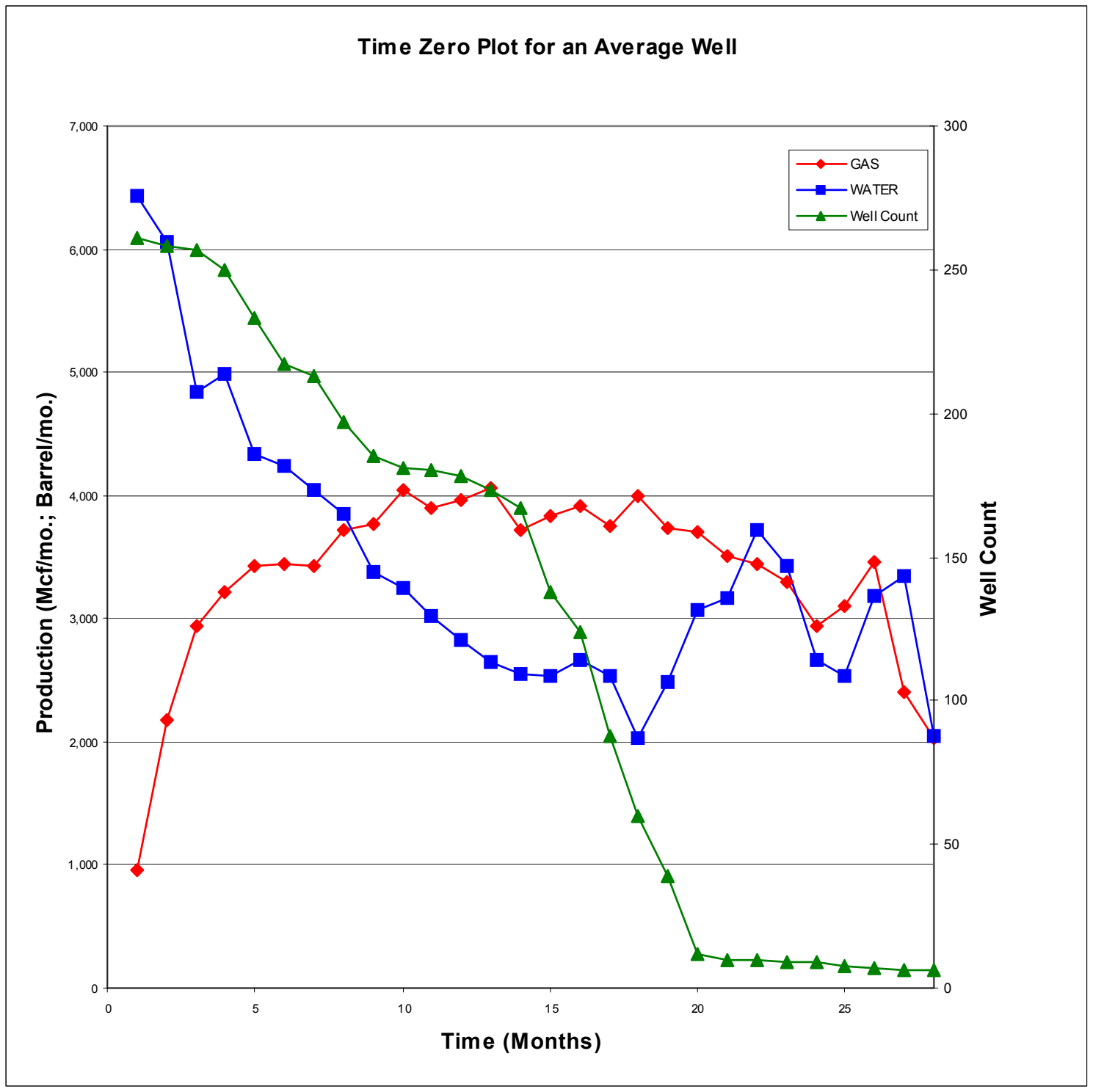

Figure 6-39. Anderson Time Zero Plot 


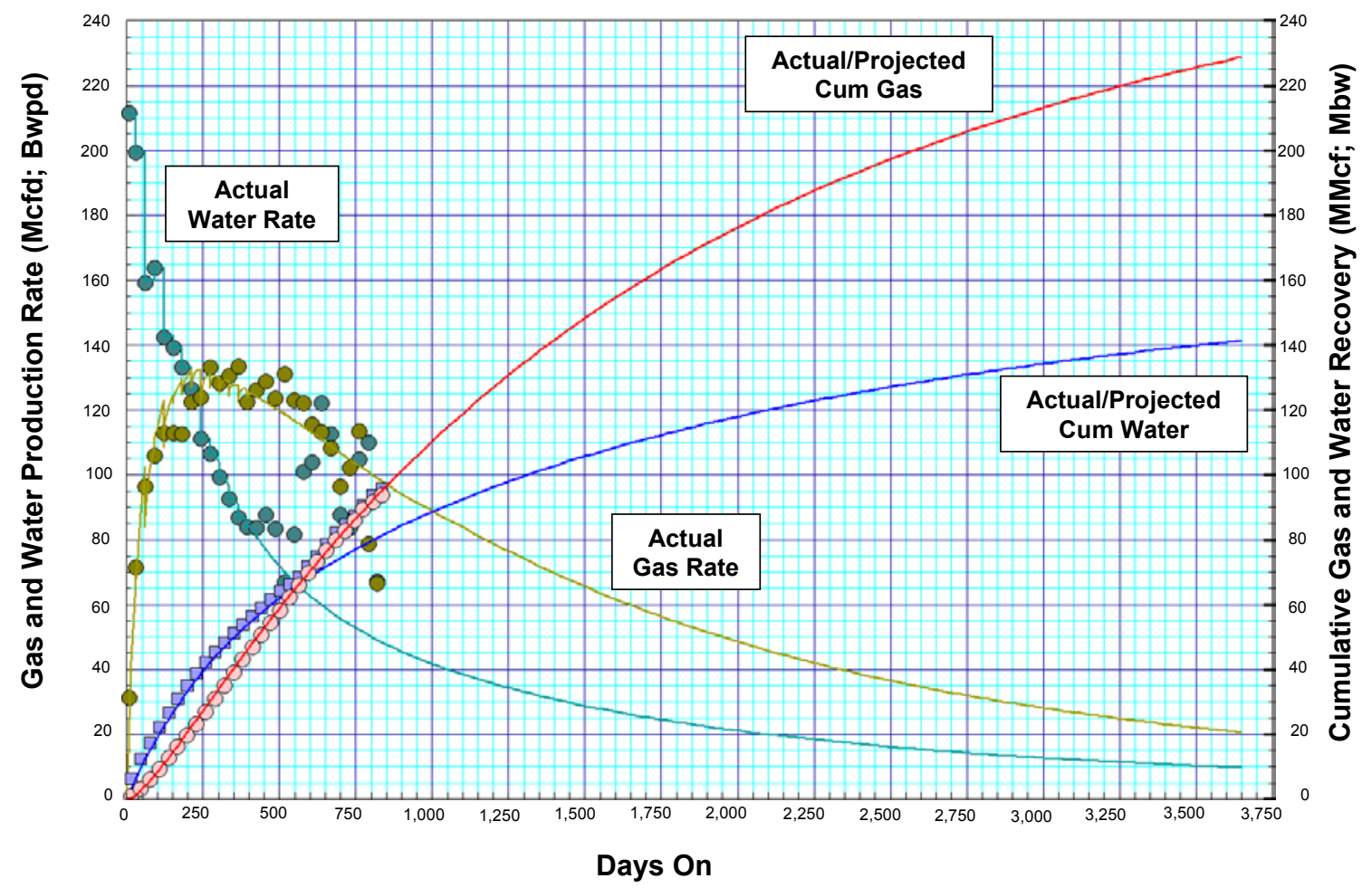

Figure 6-40. Anderson Type Well, Partition \#8 
- $\quad$ Type Well. The history-matched Canyon well in Partition \#4, adjusted for depth, gas content, permeability and coal thickness serves as the Canyon type well in this partition.

Table 6-59. Canyon Coal Seam

\begin{tabular}{|l|c|c|c|c|}
\hline \multicolumn{1}{|c|}{ Type Well } & $\begin{array}{c}\text { Well Depth } \\
\text { (ft) }\end{array}$ & $\begin{array}{c}\text { Coal Thickness } \\
\text { (ft) }\end{array}$ & $\begin{array}{c}\text { Cumulative Gas } \\
\text { Recovery } \\
\text { (Bcf) }\end{array}$ & $\begin{array}{c}\text { Cumulative } \\
\text { Water Recovery } \\
\text { (M bls) }\end{array}$ \\
\hline Average & 660 & 37 & 0.24 & 280 \\
\hline High & 950 & 47 & 0.45 & 360 \\
\hline Low & 560 & 30 & 0.17 & 230 \\
\hline
\end{tabular}

- Cook. The Cook coal seam is about 100 feet below the Canyon coal seam.

- $\quad$ Area. The Cook coal seam meets study inclusion criteria in 22 townships throughout the partition.

- Coal Thickness. The Cook seam coal thickness averages 39 feet, ranging from 25 to 52 feet.

- Coal Depth. The depth to the top of the Cook seam averages 730 feet, with a depth range of 400 to 1,200 feet.

- Development. The are a total of 1,211 drilled and permitted Cook CBM wells in Partition \#8.

- $\quad$ Time Zero Plot. The time zero plot for 134 producing Cook coal seam wells is provided in Figure 6-41. Initial water rates are 400 barrels per day declining to about 200 barrels per day after 1 year. Gas production begins immediately with an initial rate of $70 \mathrm{Mcfd}$. The gas rate continues to climb through 18 months to $200 \mathrm{Mcfd}$.

- $\quad$ Type Well. The history-matched type well for the Cook coal seam is provided in Figure 6-42. After normalizing for coal thickness, depth and gas content, the estimated gas and water recoveries are as follows in Table 6-60.

Table 6-60. Cook Coal Seam

\begin{tabular}{|l|c|c|c|c|}
\hline \multicolumn{1}{|c|}{ Type Well } & $\begin{array}{c}\text { Well Depth } \\
\text { (ft) }\end{array}$ & $\begin{array}{c}\text { Coal Thickness } \\
\text { (ft) }\end{array}$ & $\begin{array}{c}\text { Cumulative Gas } \\
\text { Recovery } \\
\text { (Bcf) }\end{array}$ & $\begin{array}{c}\text { Cumulative } \\
\text { Water Recovery } \\
\text { (M bls) }\end{array}$ \\
\hline Average & 770 & 39 & 0.27 & 270 \\
\hline High & 970 & 52 & 0.46 & 350 \\
\hline Low & 530 & 25 & 0.12 & 170 \\
\hline
\end{tabular}




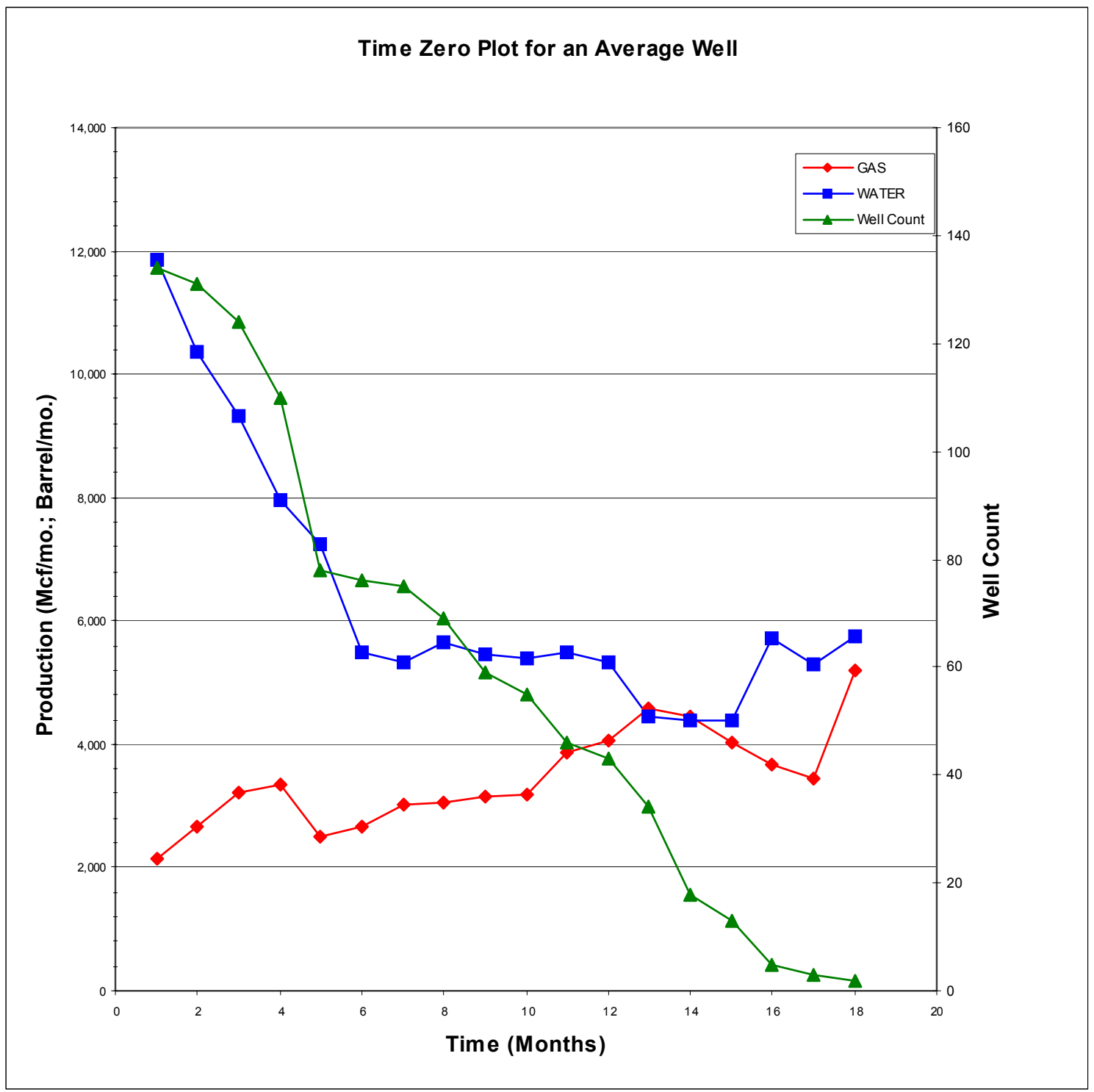

Figure 6-41. Cook Time Zero Plot 


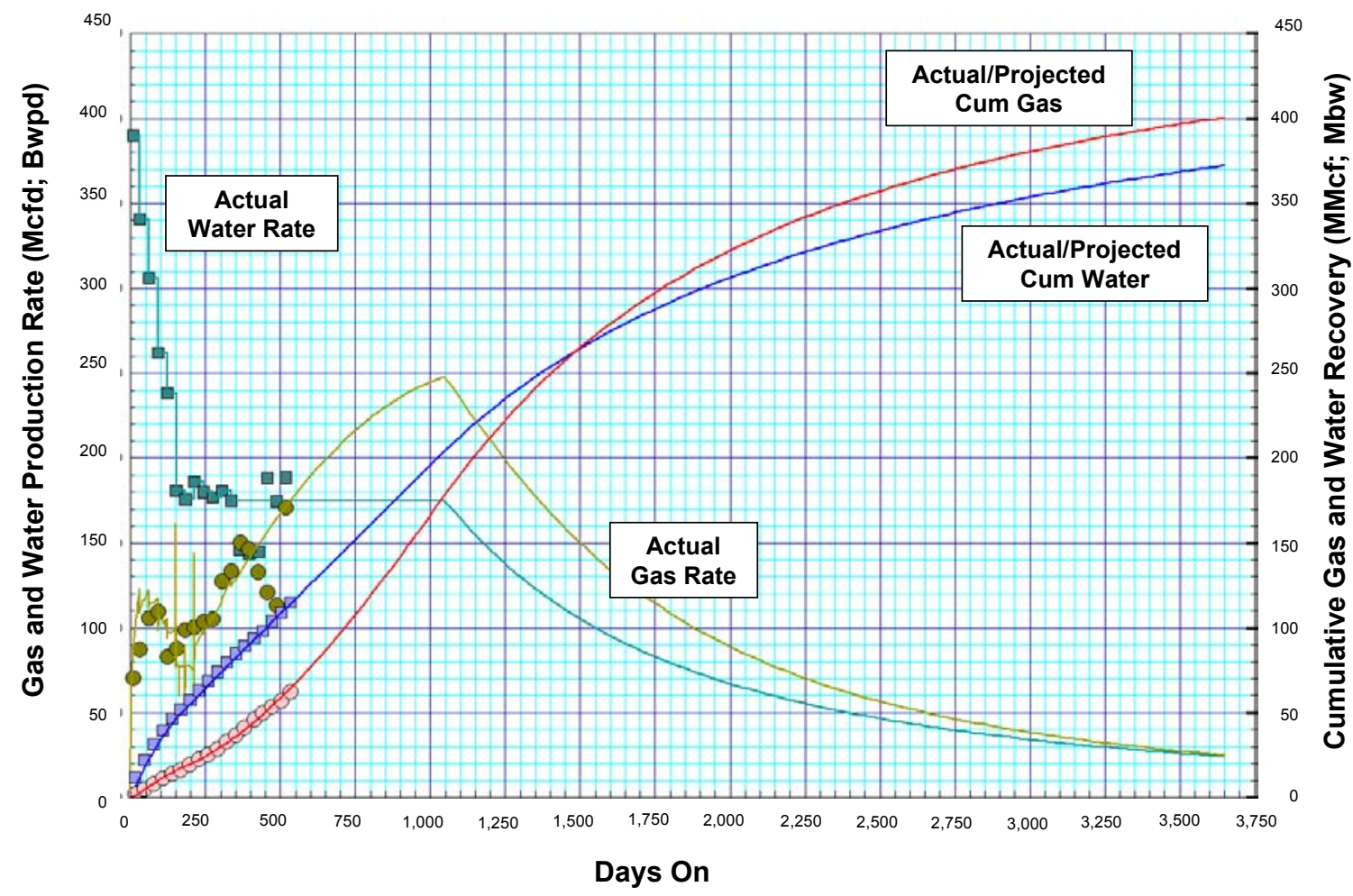

Figure 6-42. Cook Type Well, Partition \#8 
- Wall. The Wall seam is stratigraphically below the Cook seam, separated by an average of 230 feet of section.

- $\quad$ Area. The Wall coal seam meets study inclusion criteria in 21 townships throughout the partition.

- Coal Thickness. The Wall seam coal thickness averages 30 feet, with a range of 20 to 40 feet.

- Coal Depth. The depth to the top of the Wall seam averages 960 feet, with a depth range of 530 to 1,300 feet.

- Development. The are 486 drilled and permitted Wall CBM wells in Partition \#8.

- $\quad$ Time Zero Plot. The time zero plot for 107 producing Cook coal seam wells is provided in Figure 6-43. Initial water rates are about 200 barrels per day and remain high for 15 months. Gas production begins slowly with an initial rate of $10 \mathrm{Mcfd}$. The gas rate gradually climbs to a maximum of $100 \mathrm{Mcfd}$ at the end of 2 years.

- $\quad$ Type Well. The history-matched type well for the Wall coal seam is provided in Figure 6-44. After normalizing for coal thickness, depth and gas content, the estimated gas and water recoveries are as follows in Table 6-61.

Table 6-61. Wall Coal Seam

\begin{tabular}{|l|c|c|c|c|}
\hline \multicolumn{1}{|c|}{ Type Well } & $\begin{array}{c}\text { Well Depth } \\
\text { (ft) }\end{array}$ & $\begin{array}{c}\text { Coal Thickness } \\
\text { (ft) }\end{array}$ & $\begin{array}{c}\text { Cumulative Gas } \\
\text { Recovery } \\
\text { (Bcf) }\end{array}$ & $\begin{array}{c}\text { Cumulative } \\
\text { Water Recovery } \\
\text { (M bls) }\end{array}$ \\
\hline Average & 990 & 30 & 0.20 & 390 \\
\hline High & 1,120 & 40 & 0.30 & 530 \\
\hline Low & 800 & 20 & 0.11 & 260 \\
\hline
\end{tabular}

- Pawnee. The Pawnee coal seam is the deepest, currently producing major coal in this partition.

- $\quad$ Area. The Pawnee coal seam meets study inclusion criteria in 11 townships.

- Coal Thickness. The Pawnee seam coal thickness averages 33 feet, ranging from 25 to 40 feet.

- Coal Depth. The depth to the top of the Pawnee seam averages 1,060 feet, ranging from 600 to 1,400 feet.

- Development. There are 150 Pawnee CBM wells drilled and permitted in Partition \#8. 


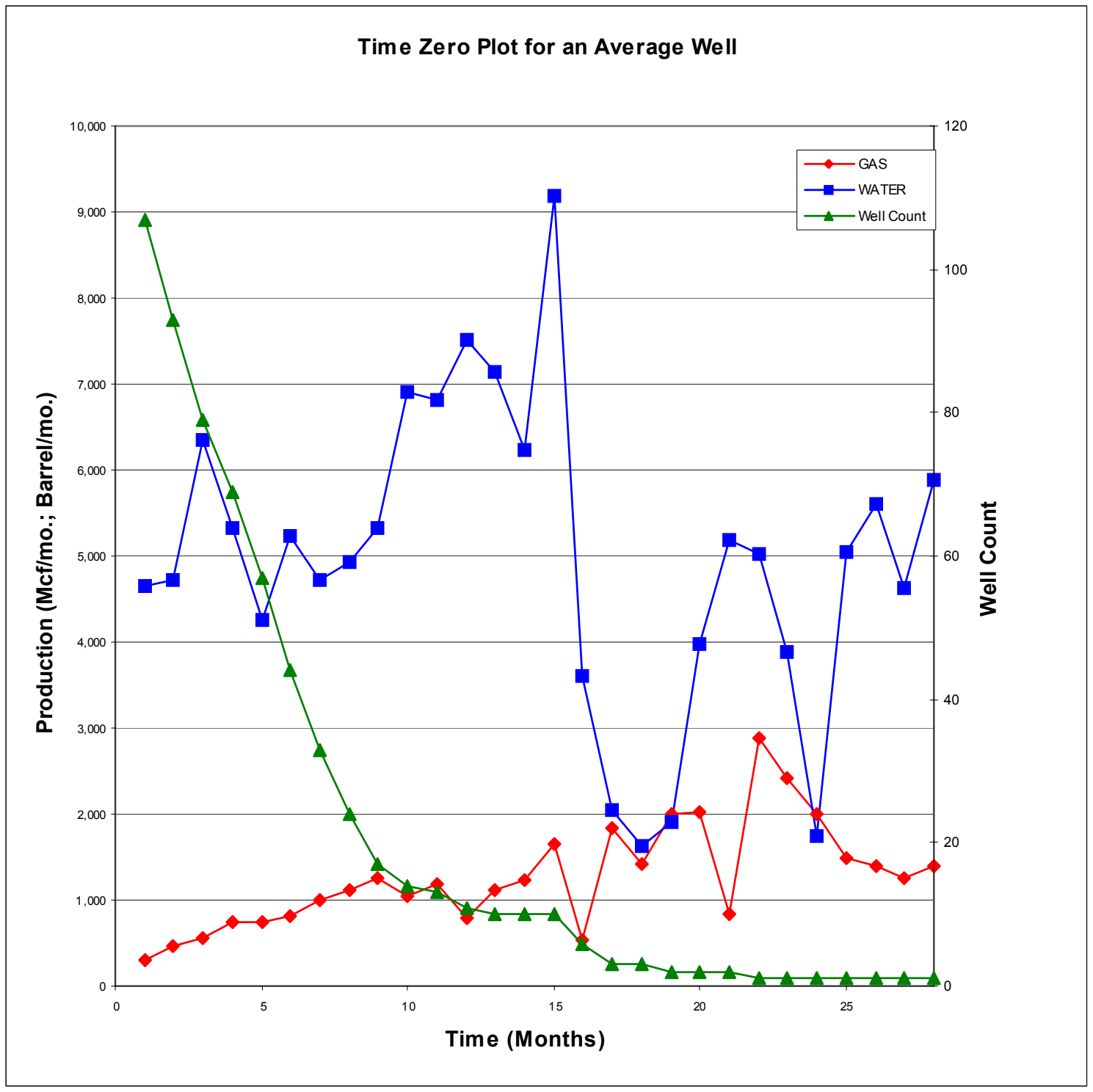

Figure 6-43. Wall Time Zero Plot 


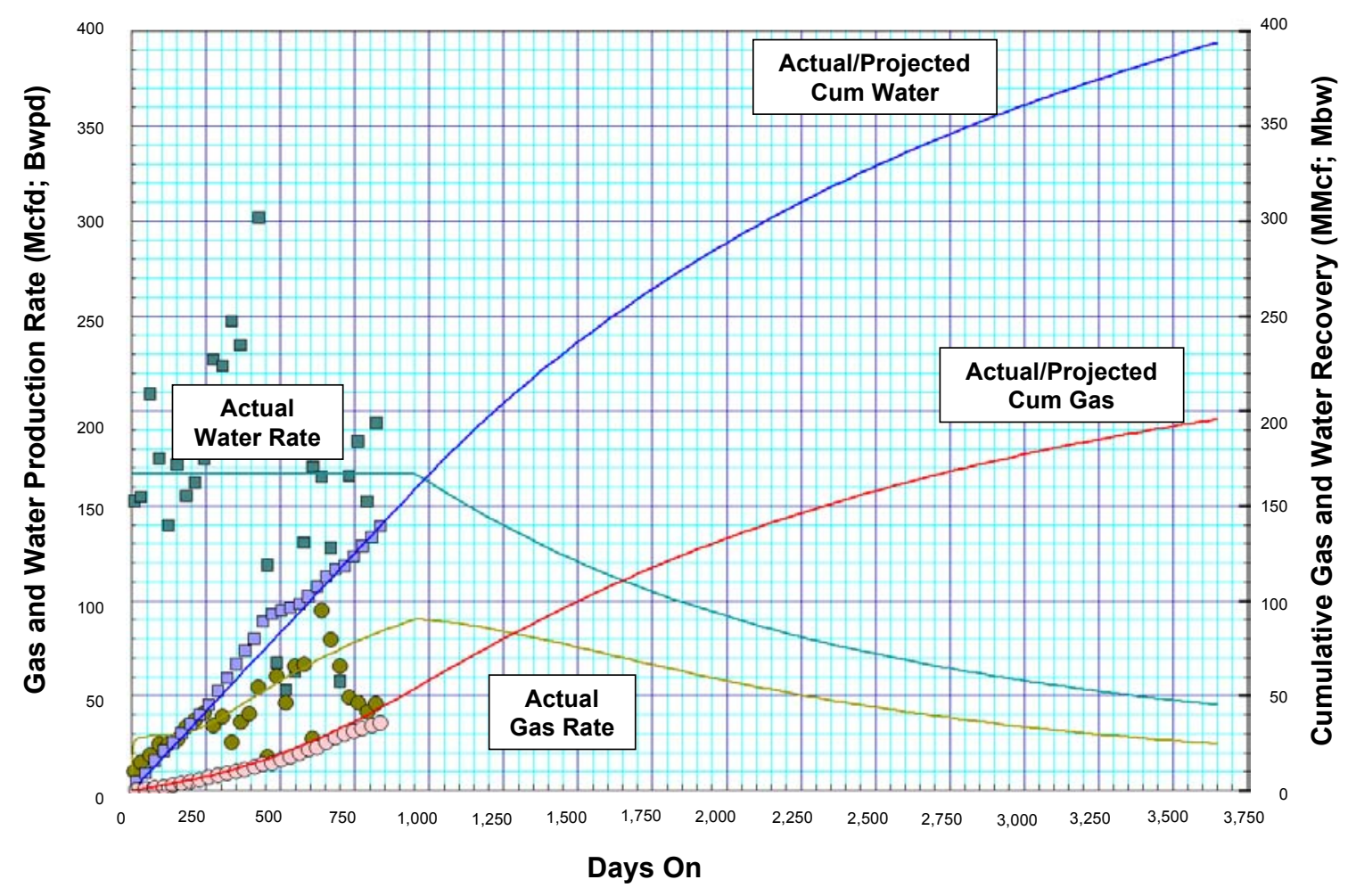

Figure 6-44. Wall Type Well Partition \#8 
- $\quad$ Time Zero Well. The time zero plot for 19 producing Pawnee coal seam wells is provided in Figure 6-45. Initial water rates are 300 barrels per day. Gas production begins slowly with an initial rate of $10 \mathrm{Mcfd}$, but steadily climbs to over 200 Mcfd in 8 months.

- $\quad$ Type Well. The history-matched type well for the Pawnee coal seam is provided in Figure 6-46. After normalizing for coal thickness, depth and gas content, the estimated gas and water recoveries are as follows:

Table 6-62. Pawnee Coal Seam

\begin{tabular}{|l|c|c|c|c|}
\hline \multicolumn{1}{|c|}{ Type Well } & $\begin{array}{c}\text { Well Depth } \\
\text { (ft) }\end{array}$ & $\begin{array}{c}\text { Coal Thickness } \\
\text { (ft) }\end{array}$ & $\begin{array}{c}\text { Cumulative Gas } \\
\text { Recovery } \\
\text { (Bcf) }\end{array}$ & $\begin{array}{c}\text { Cumulative } \\
\text { Water Recovery } \\
\text { (M bls) }\end{array}$ \\
\hline Average & 1,090 & 33 & 0.35 & 430 \\
\hline High & 840 & 40 & 0.33 & 530 \\
\hline Low & 1,330 & 25 & 0.33 & 330 \\
\hline
\end{tabular}

- $\quad$ Cache. The Cache seam is separated from the Pawnee seam by an average of 490 feet.

- $\quad$ Area. The Cache coal seam meets study inclusion criteria in 4 townships.

- Coal Thickness. The Cache seam coal thickness averages 27 feet, ranging from 20 to 40 feet.

- Coal Depth. The depth to the top of the Cache seam averages 1,540 feet, ranging from 1,100 to 2,430 feet.

- Development. The Cache coal seam is undeveloped in Partition \#8.

- $\quad$ Time Zero Well. Not available.

- $\quad$ Type Well. The history-matched Cache well in Partition \#8, adjusted for depth, gas content, permeability and coal thickness, serves as the Cache type well for this partition.

Table 6-63. Cache Coal Seam

\begin{tabular}{|l|c|c|c|c|}
\hline \multicolumn{1}{|c|}{ Type Well } & $\begin{array}{c}\text { Well Depth } \\
\text { (ft) }\end{array}$ & $\begin{array}{c}\text { Coal Thickness } \\
\text { (ft) }\end{array}$ & $\begin{array}{c}\text { Cumulative Gas } \\
\text { Recovery } \\
\text { (Bcf) }\end{array}$ & $\begin{array}{c}\text { Cumulative } \\
\text { Water Recovery } \\
\text { (M bls) }\end{array}$ \\
\hline Average & 1,570 & 27 & 0.26 & 350 \\
\hline High & 1,140 & 40 & 0.29 & 530 \\
\hline Low & 1,370 & 20 & 0.18 & 260 \\
\hline
\end{tabular}




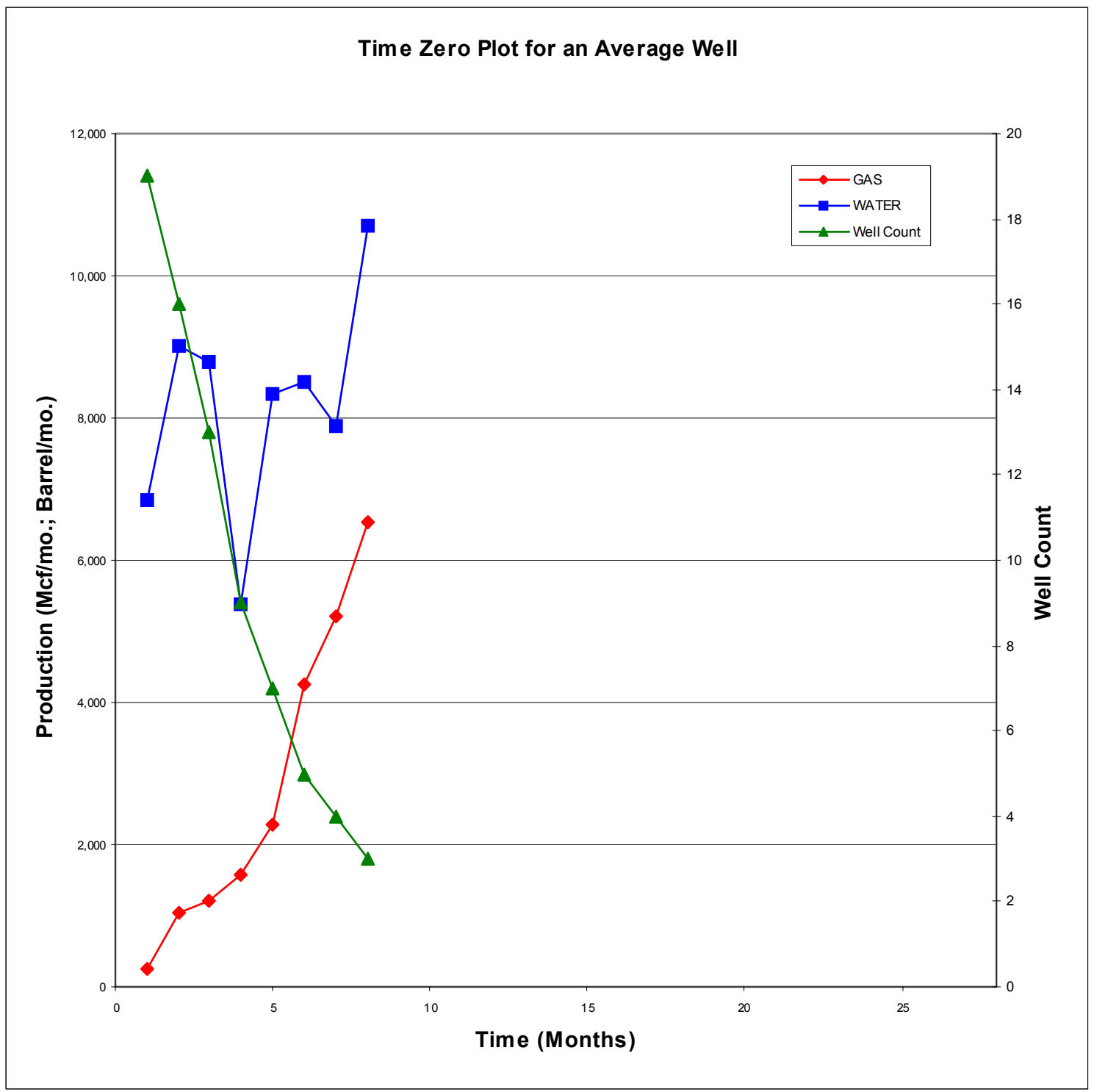

Figure 6-45. Pawnee Time Zero Plot 


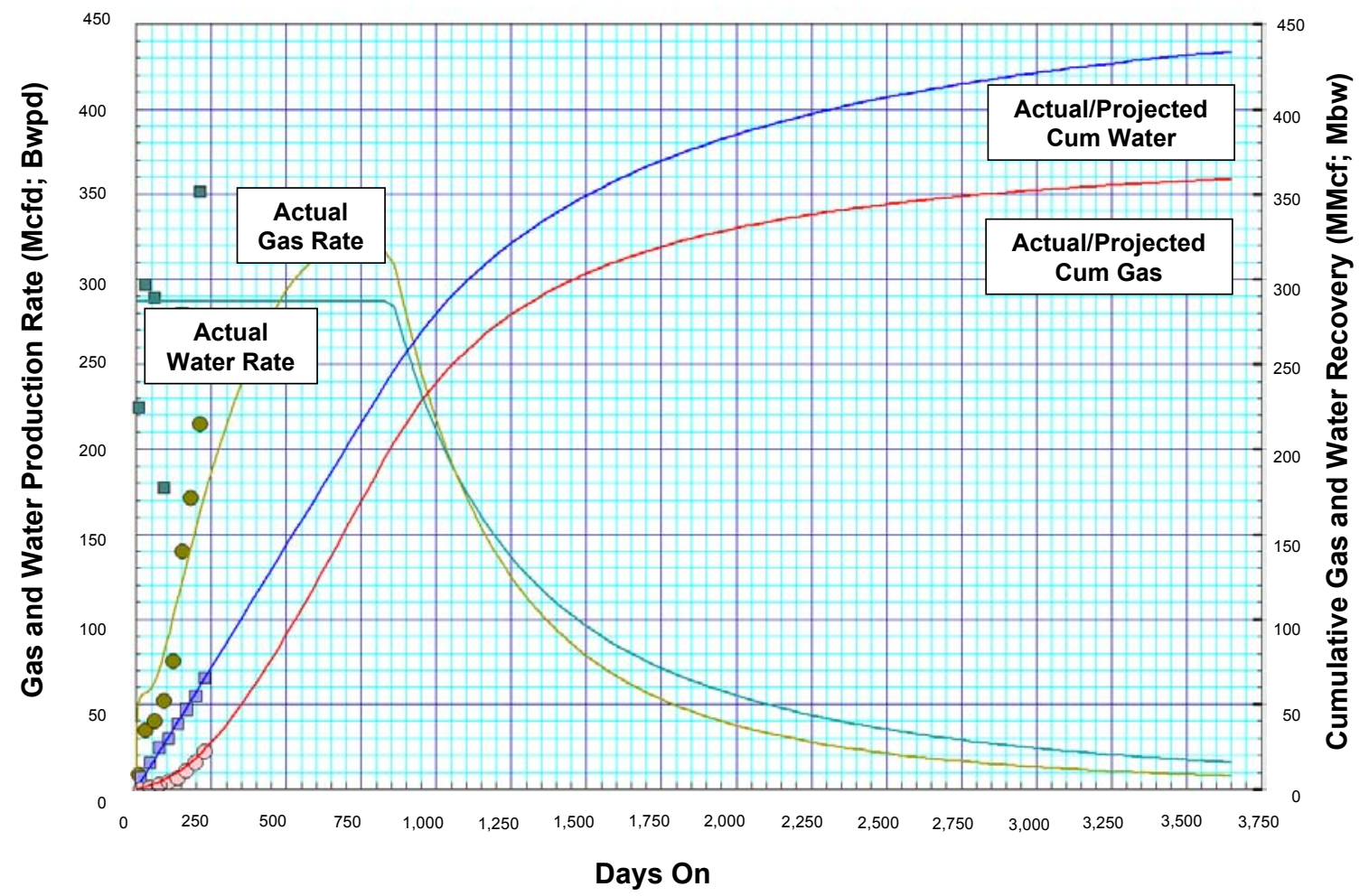

Figure 6-46. Pawnee Type Well Partition \#8 
- Oedekoven. The Oedekoven seam is the deepest major coal seam in Partition \#8, an average of 1,000 feet below the Cache seam.

- $\quad$ Area. The Oedekoven coal seam meets study inclusion criteria in 2 townships in the western portion of the partition.

- Coal Thickness. The Oedekoven seam coal thickness averages 20 feet.

- Coal Depth. The depth to the top of the Oedekoven seam averages 2,560 feet, with a depth range of 2,340 to 2,770 feet.

- Development. The Oedekoven coal seam is undeveloped in Partition \#8.

- $\quad$ Time Zero Well. Not available.

- $\quad$ Type Well. The history-matched Oedekoven well in Partition \#8, adjusted for depth, gas content, permeability and coal thickness, serves as the Oedekoven type well for Partition \#8.

Table 6-64. Oedekoven Coal Seam

\begin{tabular}{|l|c|c|c|c|}
\hline Type Well & $\begin{array}{c}\text { Well Depth } \\
\text { (ft) }\end{array}$ & $\begin{array}{c}\text { Coal Thickness } \\
\text { (ft) }\end{array}$ & $\begin{array}{c}\text { Cumulative Gas } \\
\text { Recovery } \\
\text { (Bcf) }\end{array}$ & $\begin{array}{c}\text { Cumulative } \\
\text { Water Recovery } \\
\text { (M bls) }\end{array}$ \\
\hline Average & 2,580 & 20 & 0.30 & 260 \\
\hline
\end{tabular}

Table 6-65. In-Place and Technically Recoverable CBM, Partition \#8

\begin{tabular}{|l||r|r|r|r||r|r|}
\hline Coal Seam & $\begin{array}{c}\text { No. Full } \\
\text { Townships }\end{array}$ & $\begin{array}{c}\text { Average } \\
\text { Depth } \\
\text { (ft)* }\end{array}$ & $\begin{array}{c}\text { Average } \\
\text { Thickness } \\
\text { (ft) }\end{array}$ & $\begin{array}{c}\text { Average } \\
\text { Gas Content } \\
\text { (cf/ton) }\end{array}$ & $\begin{array}{c}\text { Gas In } \\
\text { Place } \\
\text { (Bcf) }\end{array}$ & $\begin{array}{c}\text { Technically } \\
\text { Recoverable } \\
\text { (Bcf) }\end{array}$ \\
\hline Smith & 8 & 430 & 33 & 38 & 380 & 300 \\
\hline Swartz & 2 & 580 & 21 & 49 & 90 & 70 \\
\hline Anderson & 9 & 600 & 35 & 51 & 750 & 1,560 \\
\hline Canyon & 19 & 620 & 37 & 54 & 1,810 & 1,800 \\
\hline Cook & 22 & 730 & 39 & 62 & 2,280 & 1,230 \\
\hline Wall & 21 & 960 & 30 & 80 & 1,890 & 1,070 \\
\hline Pawnee & 11 & 1,060 & 33 & 87 & 1,200 & 290 \\
\hline Cache & 4 & 1,550 & 27 & 123 & 490 & 170 \\
\hline Oedekoven & 2 & 2,560 & 20 & 188 & 300 & 7,020 \\
\hline Totals & & & & & 9,190 & \\
\hline
\end{tabular}

* To top of coal 


\subsection{Partition \#9}

\subsubsection{Summary}

Partition \#9 covers 22 townships in the eastern Montana portion of the Powder River Basin, Figure 6-47. Only one township in Partition \#9 contains coal that meets the depth and thickness criteria of the study, the Pawnee seam, with 20 feet of coal at 1,075 feet. As such, the discussion of the Pawnee coal in this partition is combined into Partition \#10, on the west of Partition \#9.

\subsection{Partition \#10}

\subsubsection{Summary}

The main features of Partition \#10, in the western Montana portion of the Powder River Basin, are as follows:

- $\quad$ The partition covers a 10-township area on the western edge of the PRB, from 6S to 9S and from 39E to 41E, Figure 6-48.

- A series of coal mines exist in the townships along the northern edge and the coals shallow to the north; as a result, the townships on the northern edge of the partition are excluded.

- The stratigraphic section contains the Deitz (Anderson equivalent), the Monarch (Canyon equivalent), and the Carney (Cook equivalent) seams, plus the Pawnee coal seam from Partition \#9. The depth of these coals range from 250 to 1,200 feet, with coal seam thickness ranging from 20 to 50 feet (township level averages).

- The gas in place in the two partitions is $1.0 \mathrm{Tcf}$, with technically recoverable gas of 860 Bcf. The results by coal seam are provided in Table 6-70.

\subsubsection{Discussion of Major Seams}

- $\quad$ Dietz (Anderson). The Dietz is the uppermost significant seam in Partition \#10 and contains three subunits, called Dietz \#1, \#2, and \#3.

- $\quad$ Area. The Dietz coal seam meets study inclusion criteria in 2 townships, located in the southern portion of Partition \#10.

- Coal Thickness. The Dietz seam coal thickness averages 49 feet. The thickness of the Dietz in any locale depends on how many of the Dietz subunits are present and have been combined.

- Coal Depth. The depth to the top of the Dietz seam averages 250 feet.

- Development. A limited number of Dietz wells currently exist in this partition. 


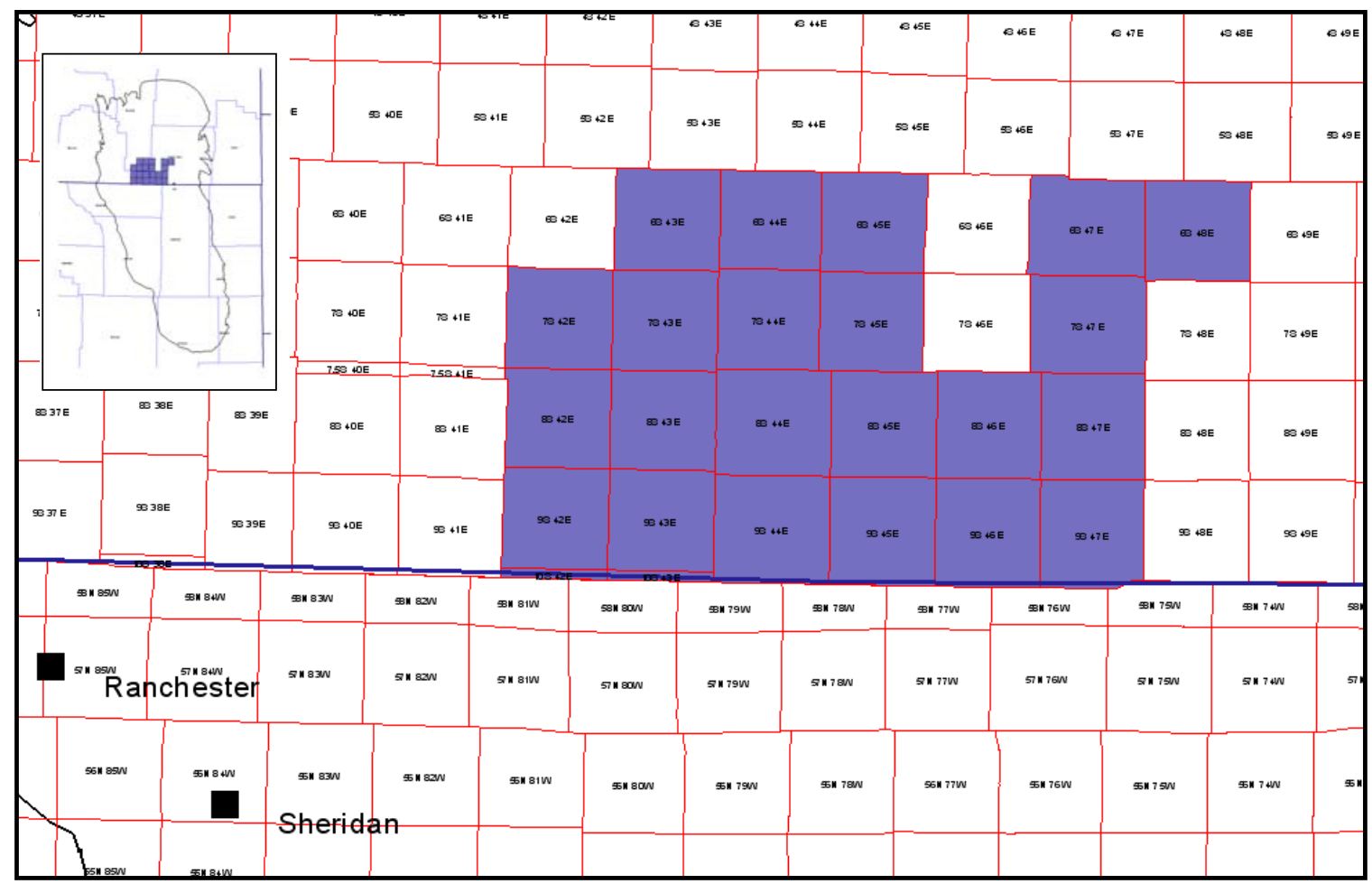

Figure 6-47. Partition \#9 Base Map 


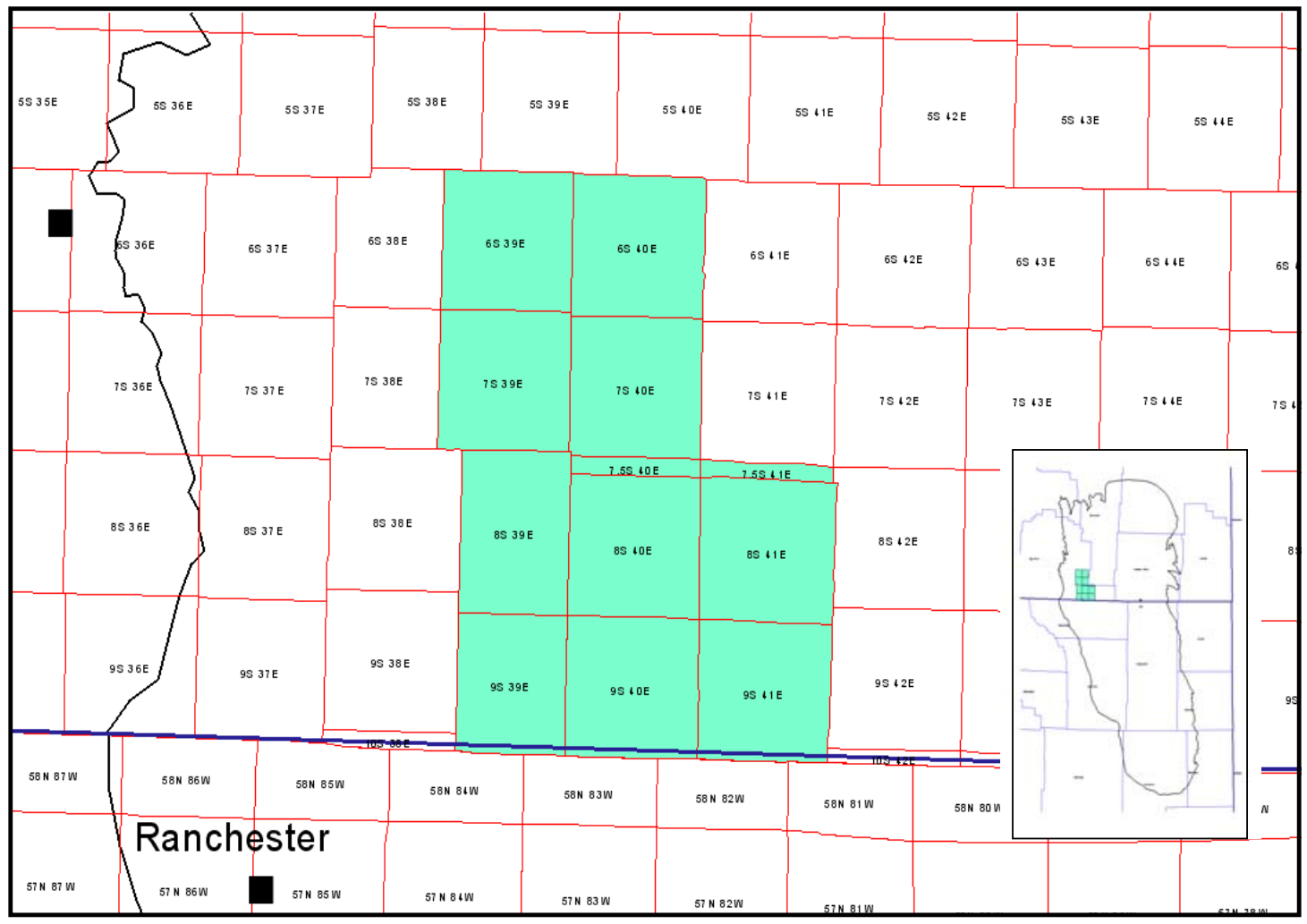

Figure 6-48. Partition \#10 Base Map 
- $\quad$ Time Zero Plot. The time zero plot for 22 recently drilled Dietz coal wells is provided in Figure 6-49.

- Type Well. The history-matched Dietz well in Partition \#11, adjusted for depth, gas content and coal thickness, serves as the Dietz type well for Partition \#10. Because the Dietz coal seam exists in only two townships, only one average well is used in Partition \#10.

Table 6-66. Dietz Coal Seam

\begin{tabular}{|l|c|c|c|c|}
\hline Type Well & $\begin{array}{c}\text { Well Depth } \\
\text { (ft) }\end{array}$ & $\begin{array}{c}\text { Coal Thickness } \\
\text { (ft) }\end{array}$ & $\begin{array}{c}\text { Cumulative Gas } \\
\text { Recovery } \\
\text { (Bcf) }\end{array}$ & $\begin{array}{c}\text { Cumulative } \\
\text { Water Recovery } \\
\text { (M bls) }\end{array}$ \\
\hline Average & 300 & 49 & 0.16 & 410 \\
\hline
\end{tabular}

- Monarch (Canyon). The major coal seam in Partition \#10 is the Monarch, located in the southern portion of the partition.

- $\quad$ Area. The Monarch coal seam meets study inclusion criteria in 7 townships.

- Coal Thickness. The Monarch coal seam thickness averages 24 feet, with a range of 20 to 30 feet.

- Coal Depth. The depth to the top of the Monarch seam averages 470 feet, with a range of 325 to 680 feet.

- Development. Considerable Monarch coal well development exists in this partition.

- $\quad$ Time Zero Plot. The time zero plot for 25 recently drilled Monarch coal wells is provided in Figure 6-50.

- Type Well. The Monarch well production profile in Partition \#10 is similar to the Monarch wells in Partition \#11. Thus, the history-matched Monarch well in Partition \#11, adjusted for depth, gas content and coal thickness, serves as the Monarch type well in this partition.

Table 6-67. Monarch Coal Seam

\begin{tabular}{|l|c|c|c|c|}
\hline \multicolumn{1}{|c|}{ Type Well } & $\begin{array}{c}\text { Well Depth } \\
\text { (ft) }\end{array}$ & $\begin{array}{c}\text { Coal Thickness } \\
\text { (ft) }\end{array}$ & $\begin{array}{c}\text { Cumulative Gas } \\
\text { Recovery } \\
\text { (Bcf) }\end{array}$ & $\begin{array}{c}\text { Cumulative } \\
\text { Water Recovery } \\
\text { (M bls) }\end{array}$ \\
\hline Average & 490 & 24 & 0.12 & 420 \\
\hline High & 580 & 30 & 0.17 & 530 \\
\hline Low & 420 & 20 & 0.08 & 350 \\
\hline
\end{tabular}




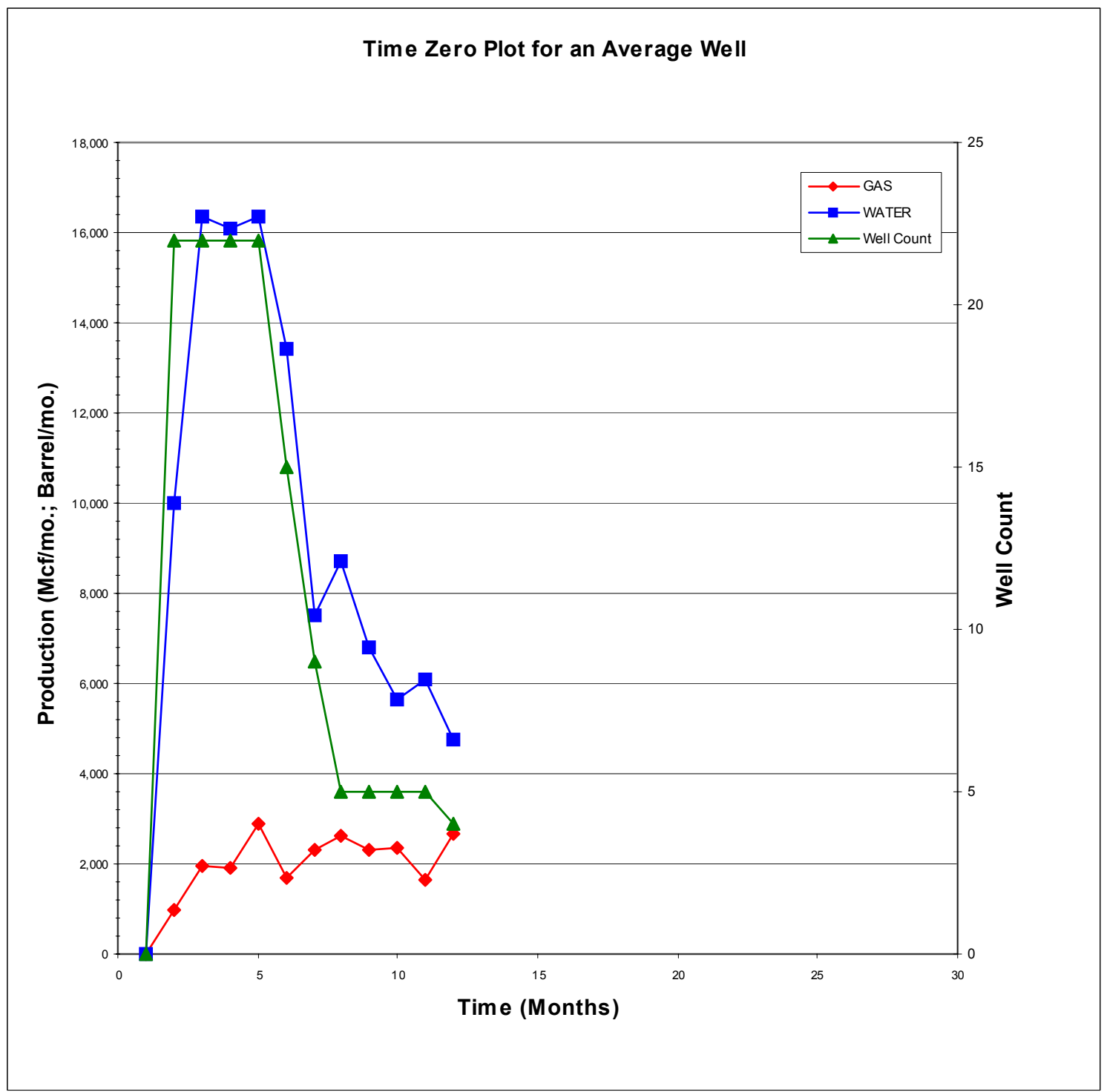

Figure 6-49. Dietz Time Zero Plot 
- Carney (Cook). The Carney coal seam exists at sufficient thickness in the central and southern portions of Partition \#10.

- $\quad$ Area. The Carney coal seam meets study inclusion criteria in seven townships.

- $\quad$ Coal Thickness. The Carney coal seam thickness averages 23 feet, with a range of 15 to 35 feet.

- Coal Depth. The depth to the top of the Carney seam averages 650 feet, with a range of 530 to 860 feet.

- Development. The Carney coal seam is lightly developed.

- $\quad$ Time Zero Plot. The time zero plot for 25 recently drilled Carney coal wells is provided in Figure 6-51.

- $\quad$ Type Well. The history-matched Carney well in Partition \#11, adjusted for depth, gas content, and coal thickness, serves as the Carney type well for Partition \#10.

Table 6-68. Carney Coal Seam

\begin{tabular}{|l|c|c|c|c|}
\hline \multicolumn{1}{|c|}{ Type Well } & $\begin{array}{c}\text { Well Depth } \\
\text { (ft) }\end{array}$ & $\begin{array}{c}\text { Coal Thickness } \\
\text { (ft) }\end{array}$ & $\begin{array}{c}\text { Cumulative Gas } \\
\text { Recovery } \\
\text { (Bcf) }\end{array}$ & $\begin{array}{c}\text { Cumulative } \\
\text { Water Recovery } \\
\text { (M bls) }\end{array}$ \\
\hline Average & 670 & 23 & 0.15 & 390 \\
\hline High & 685 & 35 & 0.23 & 590 \\
\hline Low & 870 & 15 & 0.13 & 250 \\
\hline
\end{tabular}

- Pawnee. The Pawnee seam exists in Partition \#9 (eastern Montana portion of the PRB) and includes one undesignated (wildcat) seam in Partition \#10, as discussed above.

- $\quad$ Area. The Pawnee coal seam (including the wildcat coal seam) meets study inclusion criteria in 3 townships.

- Coal Thickness. The Pawnee seam coal thickness averages 20 feet, with a range of 20 to 22 feet.

- Coal Depth. The depth to the top of the Pawnee seam averages 1,100 feet, with a range of 1,000 to 1,200 feet.

- Development. The Pawnee coal seam is undeveloped.

- $\quad$ Time Zero Plot. Not available.

- Type Well. The history-matched Pawnee well in Partition \#8, adjusted for depth, gas content, permeability and coal thickness, serves as the Pawnee type well for 


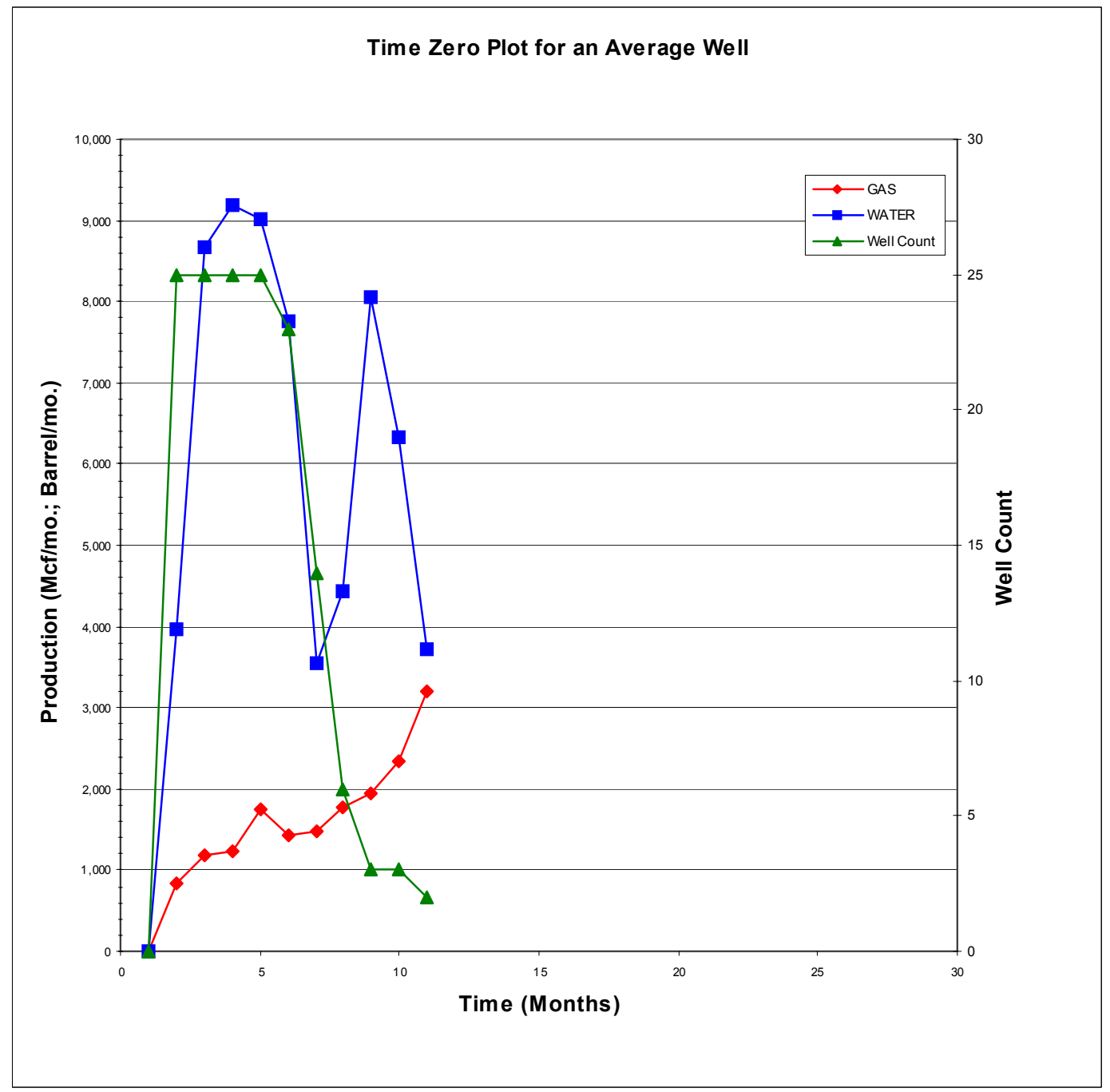

Figure 6-50. Monarch Time Zero Plot 
Partition \#10. Because the Pawnee coal seam has relatively uniform depth and thickness, only an average well is used.

Table 6-69. Pawnee Coal Seam

\begin{tabular}{|l|c|c|c|c|}
\hline Type Well & $\begin{array}{c}\text { Well Depth } \\
\text { (ft) }\end{array}$ & $\begin{array}{c}\text { Coal Thickness } \\
\text { (ft) }\end{array}$ & $\begin{array}{c}\text { Cumulative Gas } \\
\text { Recovery } \\
\text { (Bcf) }\end{array}$ & $\begin{array}{c}\text { Cumulative } \\
\text { Water Recovery } \\
\text { (M bls) }\end{array}$ \\
\hline Average & 1,120 & 20 & 0.22 & 260 \\
\hline
\end{tabular}

Table 6-70. In-Place and Technically Recoverable CBM, Partitions \#9 and \#10

\begin{tabular}{|l||r|r|r|r||r|r|}
\hline Coal Seam & $\begin{array}{r}\text { No. Full } \\
\text { Townships }\end{array}$ & \multicolumn{1}{c|}{$\begin{array}{c}\text { Average } \\
\text { Depth } \\
\text { (ft) }\end{array}$} & $\begin{array}{c}\text { Average } \\
\text { Thickness } \\
\text { (ft) }\end{array}$ & $\begin{array}{c}\text { Average Gas } \\
\text { Content } \\
\text { (cf/ton) }\end{array}$ & $\begin{array}{r}\text { Gas in } \\
\text { Place } \\
\text { (Bcf) }\end{array}$ & $\begin{array}{c}\text { Technically } \\
\text { Recoverable } \\
\text { Resources } \\
\text { (Bcf) }\end{array}$ \\
\hline $\begin{array}{l}\text { Deitz } \\
\text { (Anderson) }\end{array}$ & 2 & 250 & 49 & 25 & 100 & 90 \\
\hline $\begin{array}{l}\text { Monarch } \\
\text { (Canyon) }\end{array}$ & 7 & 470 & 24 & 41 & 280 & 250 \\
\hline Carney (Cook) & 7 & 650 & 23 & 55 & 380 & 330 \\
\hline Pawnee & 3 & 1,080 & 20 & 88 & 210 & 190 \\
\hline Totals & & & & & 970 & 860 \\
\hline
\end{tabular}

*Top of coal

\subsection{Partition \#11}

\subsubsection{Summary}

The main features of Partition \#11, in the Wyoming portion of the Powder River Basin, are as follows:

- The partition covers a 12-township area on the northwestern portion of the PRB, from $53 \mathrm{~N}$ to $58 \mathrm{~N}$ and from $82 \mathrm{~W}$ to $84 \mathrm{~W}$, Figure $6-52$.

- The stratigraphic section contains the locally named Dietz (Anderson equivalent), Monarch (Canyon equivalent), and Carney (Cook equivalent) coal seams. The depth of these coals range from 990 to 1,070 feet, with coal seam thickness ranging from 20 to 40 feet (township level averages).

- The gas in place in the two partition is $2.1 \mathrm{Tcf}$, with technically recoverable gas of 1,850 Bcf. The results by coal seam are provided in Table 6-76. 


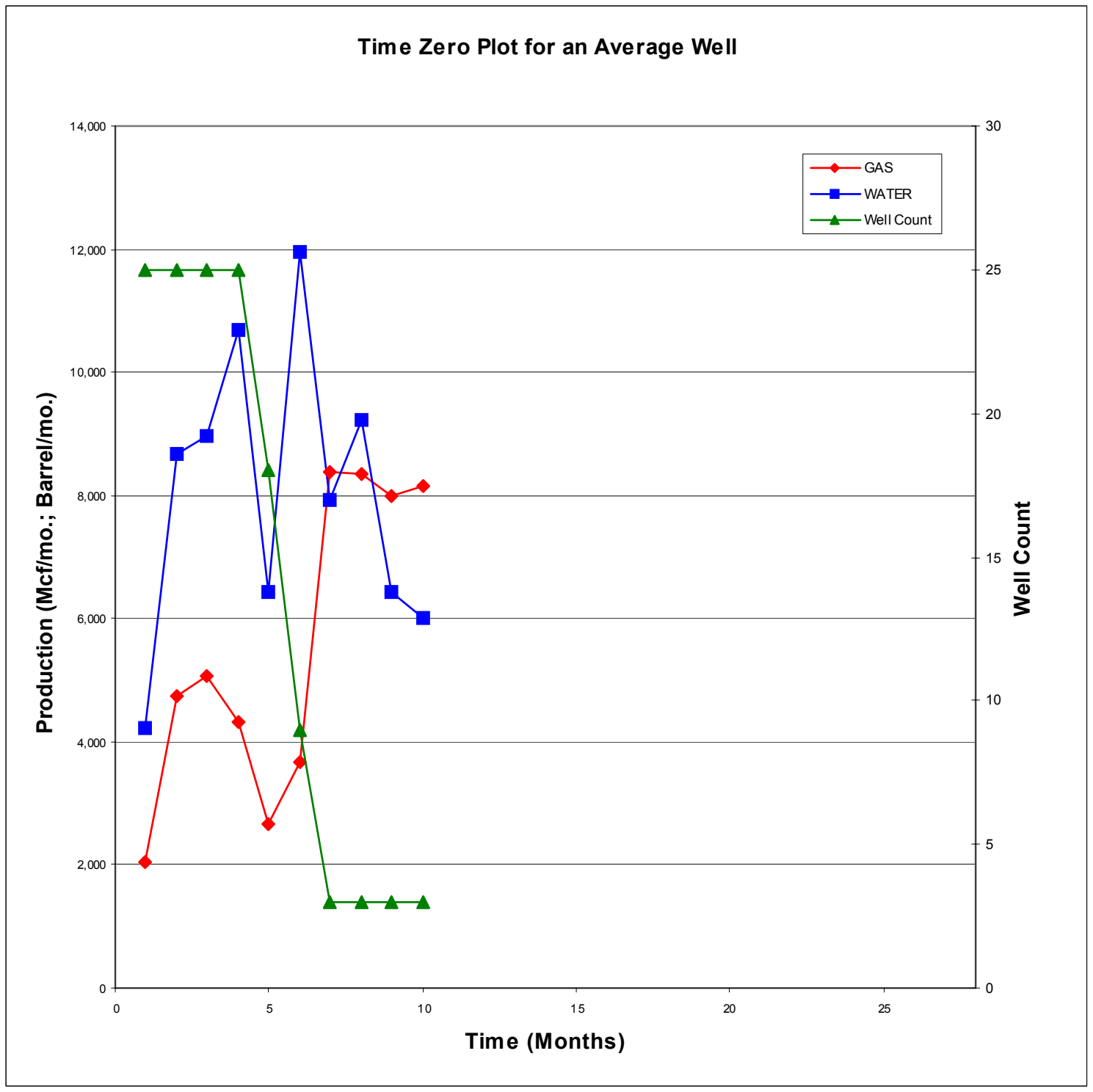

Figure 6-51. Cook-Carney Time Zero Plot 


\subsubsection{Discussion of Major Coal Seams}

- Dietz \#1 (Anderson). The Dietz \#1 coal, the first major seam, extends over much of the northern portion of Partition \#11 and shallows along the western and northern edge of the partition.

- $\quad$ Area. The Dietz \#1 coal seam meets study inclusion criteria in 5 townships.

- $\quad$ Coal Thickness. The Dietz \#1 coal seam coal thickness averages 24 feet, with a range of 20 to 25 feet.

- Coal Depth. The depth to the top of the Dietz \#1 seam averages 910 feet, with a range of 300 to 1,840 feet.

- Development. The Dietz \#1 seam is being aggressively developed.

- $\quad$ Time Zero Plot. The time zero plot for 191 producing Dietz (Anderson) coal seam wells in T57N, R83-84W is provided in Figure 6-53. After initial rates of nearly 300 barrels per day, water production declines sharply to about 180 barrels per day after 1 year. Gas production starts early at 100 to $200 \mathrm{Mcfd}$.

- $\quad$ Type Well. The type well for the Dietz (Anderson) series of coal seams (Dietz \#1, $\# 2$, and \#3) is provided in Figure 6-54. After normalizing for coal thickness, depth and gas content, the estimated gas and water recoveries for the Dietz \#1 coal seam are as follows in Table 6-71.

Table 6-71. Dietz \#1 Coal Seam

\begin{tabular}{|l|c|c|c|c|}
\hline \multicolumn{1}{|c|}{ Type Well } & $\begin{array}{c}\text { Well Depth } \\
\text { (ft) }\end{array}$ & $\begin{array}{c}\text { Coal Thickness } \\
\text { (ft) }\end{array}$ & $\begin{array}{c}\text { Cumulative Gas } \\
\text { Recovery } \\
\text { (Bcf) }\end{array}$ & $\begin{array}{c}\text { Cumulative } \\
\text { Water Recovery } \\
\text { (M bls) }\end{array}$ \\
\hline Average & 930 & 24 & 0.22 & 200 \\
\hline High & 1,140 & 25 & 0.29 & 210 \\
\hline Low & 800 & 20 & 0.16 & 170 \\
\hline
\end{tabular}

- $\quad$ Dietz \#2. The Dietz \#2 coal, the second split of the larger Dietz (Anderson) seam, exists along the northern portion of Partition \#11.

- $\quad$ Area. The Dietz \#2 coal seam meets study inclusion criteria in 5 townships.

- $\quad$ Coal Thickness. The Dietz \#2 coal seam coal thickness averages 24 feet, with a range of 20 to 30 feet.

- Coal Depth. The depth to the top of the Dietz \#2 seam averages 680 feet, with a range of 300 to 1,160 feet. 


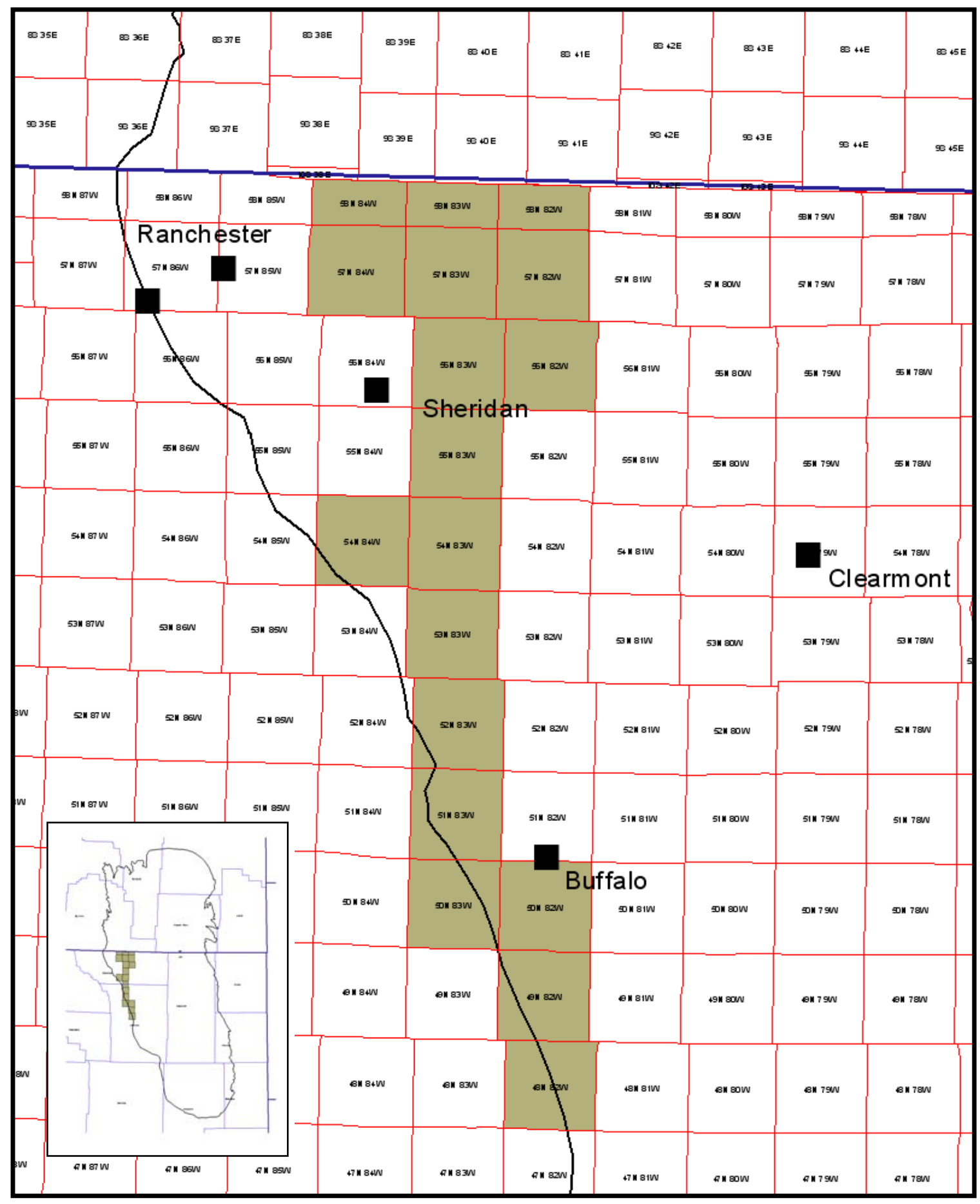

Figure 6-52. Partition \#11 Base Map 


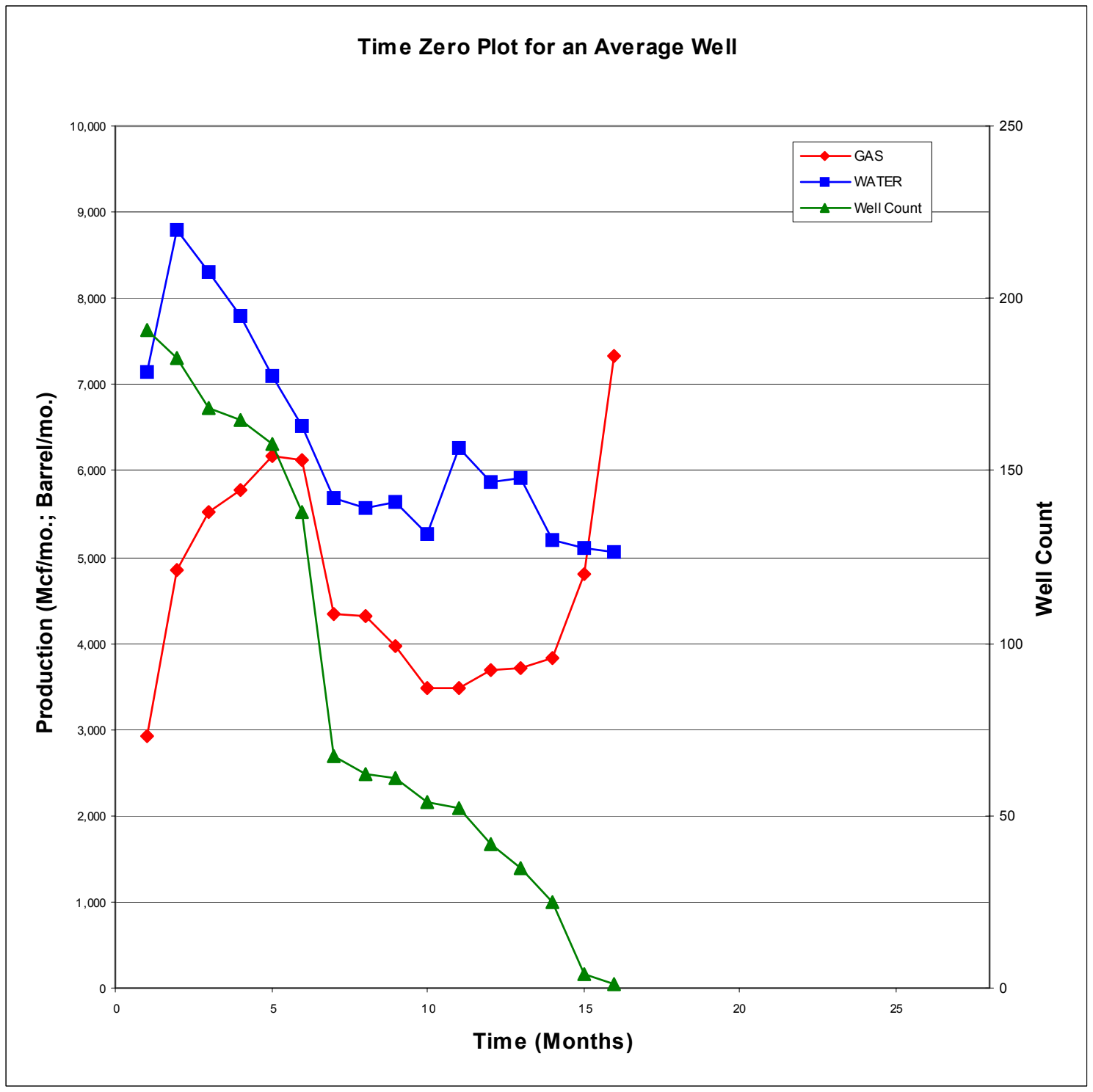

Figure 6-53. Dietz (Anderson) Time Zero Plot 
- Development. The Dietz \#2 seam is lightly developed in this area.

- $\quad$ Time Zero Plot. The time zero plot and data for Dietz \#2 coal seam wells are included in the overall Dietz time zero plot, discussed previously.

- $\quad$ Type Well. The type well for the Dietz \#2 coal seam is the aggregate Dietz well, provided previously in Figure 6-54, adjusted for coal thickness, depth and gas content. The estimated gas and water recoveries are as follows in Table 6-72.

Table 6-72. Dietz \#2 Coal Seam

\begin{tabular}{|l|c|c|c|c|}
\hline \multicolumn{1}{|c|}{ Type Well } & $\begin{array}{c}\text { Well Depth } \\
\text { (ft) }\end{array}$ & $\begin{array}{c}\text { Coal Thickness } \\
\text { (ft) }\end{array}$ & $\begin{array}{c}\text { Cumulative Gas } \\
\text { Recovery } \\
\text { (Bcf) }\end{array}$ & $\begin{array}{c}\text { Cumulative } \\
\text { Water Recovery } \\
\text { (M bls) }\end{array}$ \\
\hline Average & 700 & 24 & 0.17 & 200 \\
\hline High & 1,190 & 30 & 0.36 & 250 \\
\hline Low & 620 & 20 & 0.13 & 170 \\
\hline
\end{tabular}

- Dietz \#3. The Dietz \#3 coal, the third split of the larger Dietz (Anderson) seam, exists along the northern portion of Partition \#11.

- $\quad$ Area. The Dietz \#3 coal seam meets study inclusion criteria in 6 townships.

- $\quad$ Coal Thickness. The Dietz \#3 coal seam coal thickness averages 22 feet, with a range of 20 to 25 feet.

- Coal Depth. The depth to the top of the Dietz \#3 seam averages 1,030 feet, with a range of 350 to 1,970 feet.

- Development. The Dietz \#3 seam is lightly developed in this area.

- $\quad$ Time Zero Plot. The time zero plot and data for Dietz \#3 coal seam wells are included in the overall Dietz time zero plot, discussed previously.

- $\quad$ Type Well. The type well for the Dietz \#3 coal seam is the aggregate Dietz well, provided previously in Figure 6-54, adjusted for coal thickness, depth and gas content. The estimated gas and water recoveries are as follows below.

Table 6-73. Dietz \#3 Coal Seam

\begin{tabular}{|l|c|c|c|c|}
\hline \multicolumn{1}{|c|}{ Type Well } & $\begin{array}{c}\text { Well Depth } \\
\text { (ft) }\end{array}$ & $\begin{array}{c}\text { Coal Thickness } \\
\text { (ft) }\end{array}$ & $\begin{array}{c}\text { Cumulative Gas } \\
\text { Recovery } \\
\text { (Bcf) }\end{array}$ & $\begin{array}{c}\text { Cumulative } \\
\text { Water Recovery } \\
\text { (M bls) }\end{array}$ \\
\hline Average & 1,050 & 22 & 0.23 & 180 \\
\hline High & 980 & 25 & 0.25 & 210 \\
\hline Low & 600 & 20 & 0.12 & 170 \\
\hline
\end{tabular}


- Monarch (Canyon). The Monarch coal is stratigraphically below the Dietz and extends over much of the partition. It shallows on the western edge of the PRB basin.

- $\quad$ Area. The Monarch coal seam meets study inclusion criteria in 8 townships.

- Coal Thickness. The Monarch coal seam thickness averages 22 feet, with a range of 20 to 25 feet.

- Coal Depth. The depth to the top of the Monarch seam averages 1,070 feet, with a range of 500 to 2,200 feet.

- Development. The Monarch coal seam is under development.

- $\quad$ Time Zero Plot. The time zero plot for 147 producing Monarch (Canyon) coal seam wells in T57N, R83-84W is provided in Figure 6-55. Water production starts at 300 barrels per day and remains high for the first 2 years. Gas production starts early, reaching $200 \mathrm{Mcfd}$ in year 2 .

- $\quad$ Type Well. The type well for the Monarch (Canyon) coal seam is provided in Figure 6-56. After normalizing for coal thickness, depth and gas content, the estimated gas and water recoveries are as follows:

Table 6-74. Monarch Coal Seam

\begin{tabular}{|l|c|c|c|c|}
\hline \multicolumn{1}{|c|}{ Type Well } & $\begin{array}{c}\text { Well Depth } \\
\text { (ft) }\end{array}$ & $\begin{array}{c}\text { Coal Thickness } \\
\text { (ft) }\end{array}$ & $\begin{array}{c}\text { Cumulative Gas } \\
\text { Recovery } \\
\text { (Bcf) }\end{array}$ & $\begin{array}{c}\text { Cumulative } \\
\text { Water Recovery } \\
\text { (M bls) }\end{array}$ \\
\hline Average & 1,090 & 24 & 0.26 & 430 \\
\hline High & 1,340 & 25 & 0.32 & 440 \\
\hline Low & 820 & 20 & 0.16 & 350 \\
\hline
\end{tabular}

- Carney (Cook). The Carney coal, stratigraphically below the Monarch, exists over a limited portion of the partition.

- $\quad$ Area. The Carney coal seam meets study inclusion criteria in three townships.

- Coal Thickness. The Carney seam coal thickness averages 23 feet, with a range of 20 to 30 feet.

- Coal Depth. The depth to the top of the Carney seam averages 1,030 feet, with a range of 600 to 1,440 feet.

- Development. The Carney coal seam is undeveloped. 


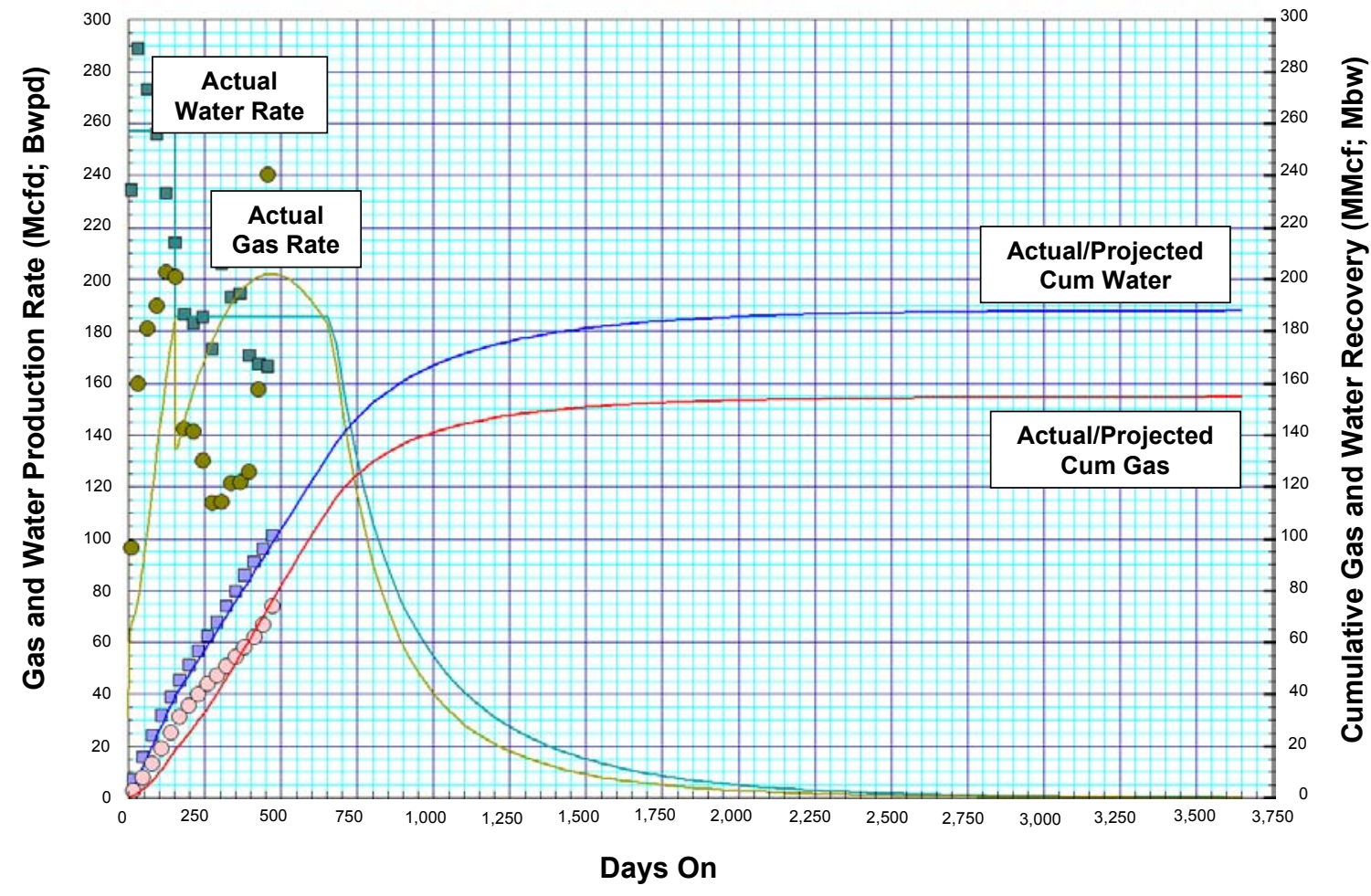

Figure 6-54. Dietz (Anderson), Partition \#11 


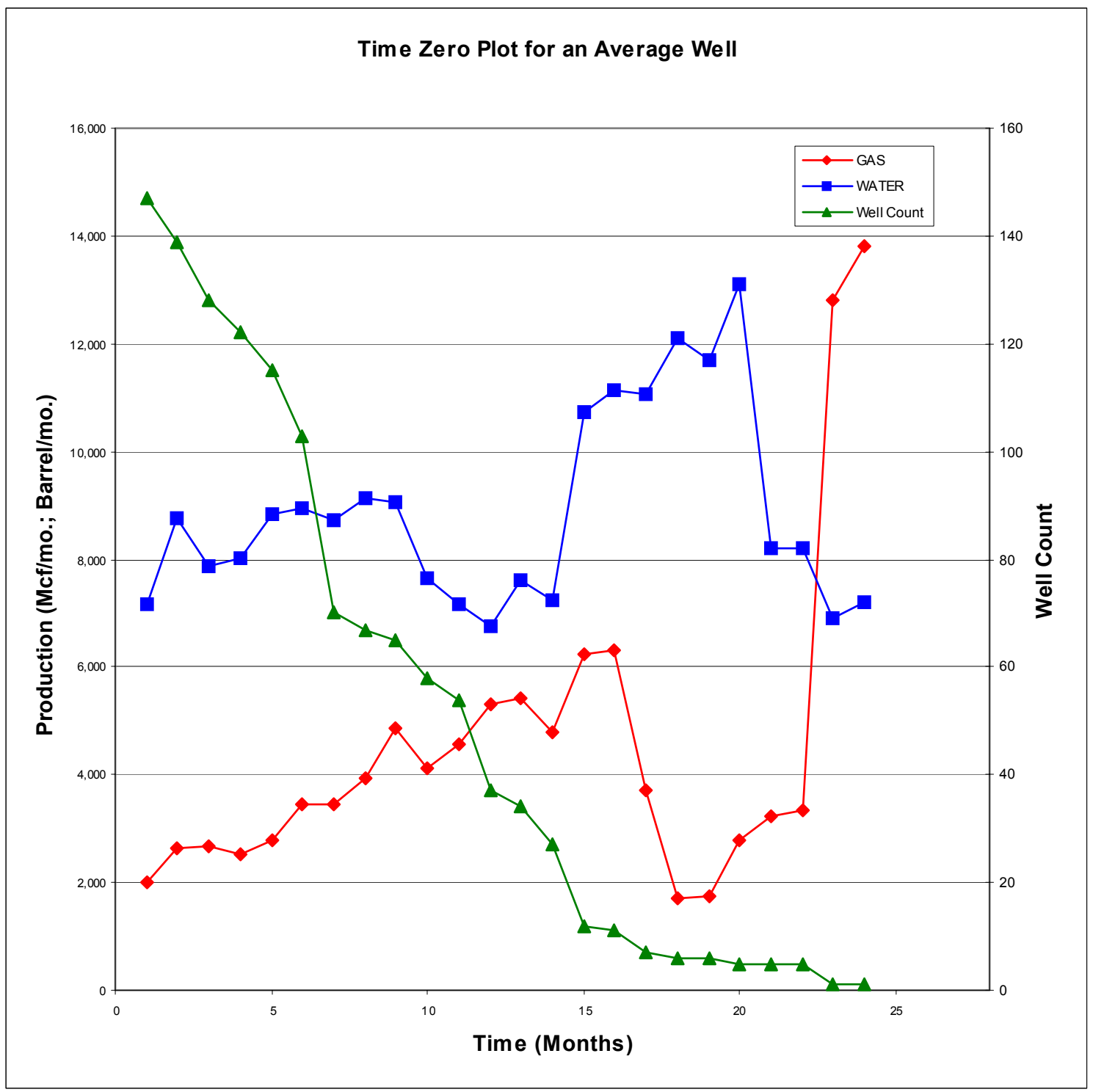

Figure 6-55. Monarch (Canyon) Time Zero Plot 
- $\quad$ Time Zero Plot. The time zero plot for 65 producing Carney (Cook) wells in Partition \#11 is provided in Figure 6-57. After initial rates of about 300 barrels of water per day, the water rates decline to about 200 barrels per day at the end of year 1 . Gas production starts early and peaks at about $200 \mathrm{Mcf}$ at the end of year 1.

- $\quad$ Type Well. The history-matched Carney (Cook equivalent) well, Figure 6-58, adjusted for depth, gas content and coal thickness, serves as the Carney type well for Partition \#11. Since only three townships include the Carney and the coal thickness is relatively uniform, only an average well is used.

Table 6-75. Carney Coal Seam

\begin{tabular}{|l|c|c|c|c|}
\hline Type Well & $\begin{array}{c}\text { Well Depth } \\
\text { (ft) }\end{array}$ & $\begin{array}{c}\text { Coal Thickness } \\
\text { (ft) }\end{array}$ & $\begin{array}{c}\text { Cumulative Gas } \\
\text { Recovery } \\
\text { (Bcf) }\end{array}$ & $\begin{array}{c}\text { Cumulative } \\
\text { Water Recovery } \\
\text { (M bls) }\end{array}$ \\
\hline Average & 1,050 & 23 & 0.23 & 390 \\
\hline
\end{tabular}

Table 6-76. In-Place and Technically Recoverable CBM, Partitions \#11

\begin{tabular}{|l||r|r|r|r||r|r|}
\hline Coal Seam & $\begin{array}{c}\text { No. Full } \\
\text { Townships }\end{array}$ & $\begin{array}{c}\text { Average } \\
\text { Depth } \\
\text { (ft) }\end{array}$ & $\begin{array}{c}\text { Average } \\
\text { Thickness } \\
\text { (ft) }\end{array}$ & $\begin{array}{c}\text { Average Gas } \\
\text { Content } \\
\text { (cf/ton) }\end{array}$ & $\begin{array}{c}\text { Gas in } \\
\text { Place } \\
\text { (Bcf) }\end{array}$ & $\begin{array}{c}\text { Technically } \\
\text { Recoverable } \\
\text { Resources } \\
\text { (Bcf) }\end{array}$ \\
\hline $\begin{array}{l}\text { Deitz \#1 } \\
\text { (Anderson) }\end{array}$ & 5 & 910 & 24 & 75 & 510 & 450 \\
\hline Dietz \#2 & 5 & 680 & 24 & 58 & 330 & 290 \\
\hline Dietz \#3 & 6 & 1,030 & 22 & 84 & 390 & 540 \\
\hline $\begin{array}{l}\text { Monarch } \\
\text { (Canyon) }\end{array}$ & 8 & 1,070 & 24 & 88 & 640 & 190 \\
\hline $\begin{array}{l}\text { Carney } \\
\text { (Cook) }\end{array}$ & 3 & 1,030 & 23 & 84 & 220 & 1,850 \\
\hline Totals & & & & & 2,090 & \\
\hline
\end{tabular}

* Top of coal 


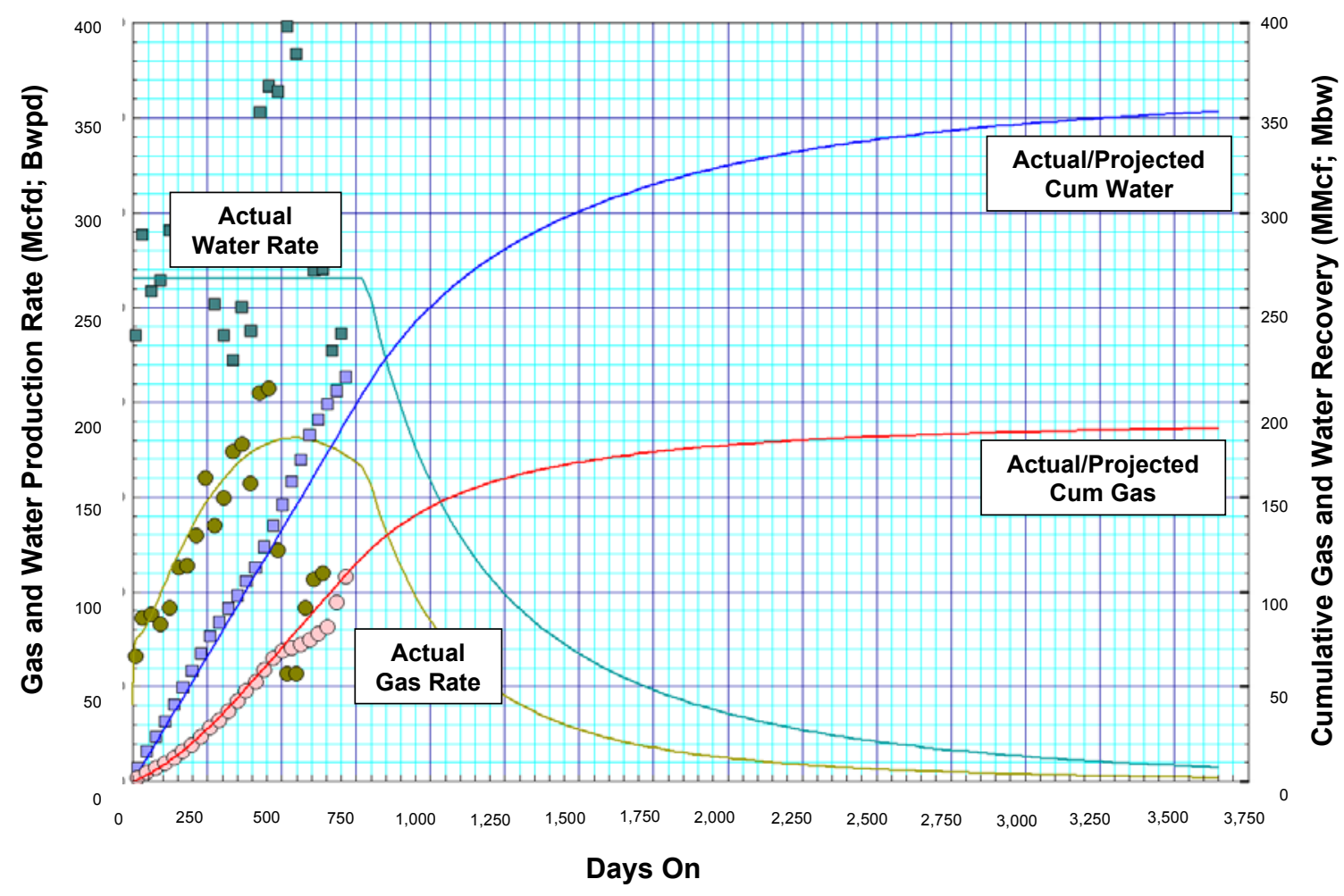

Figure 6-56. Monarch (Canyon), Partition \#11 


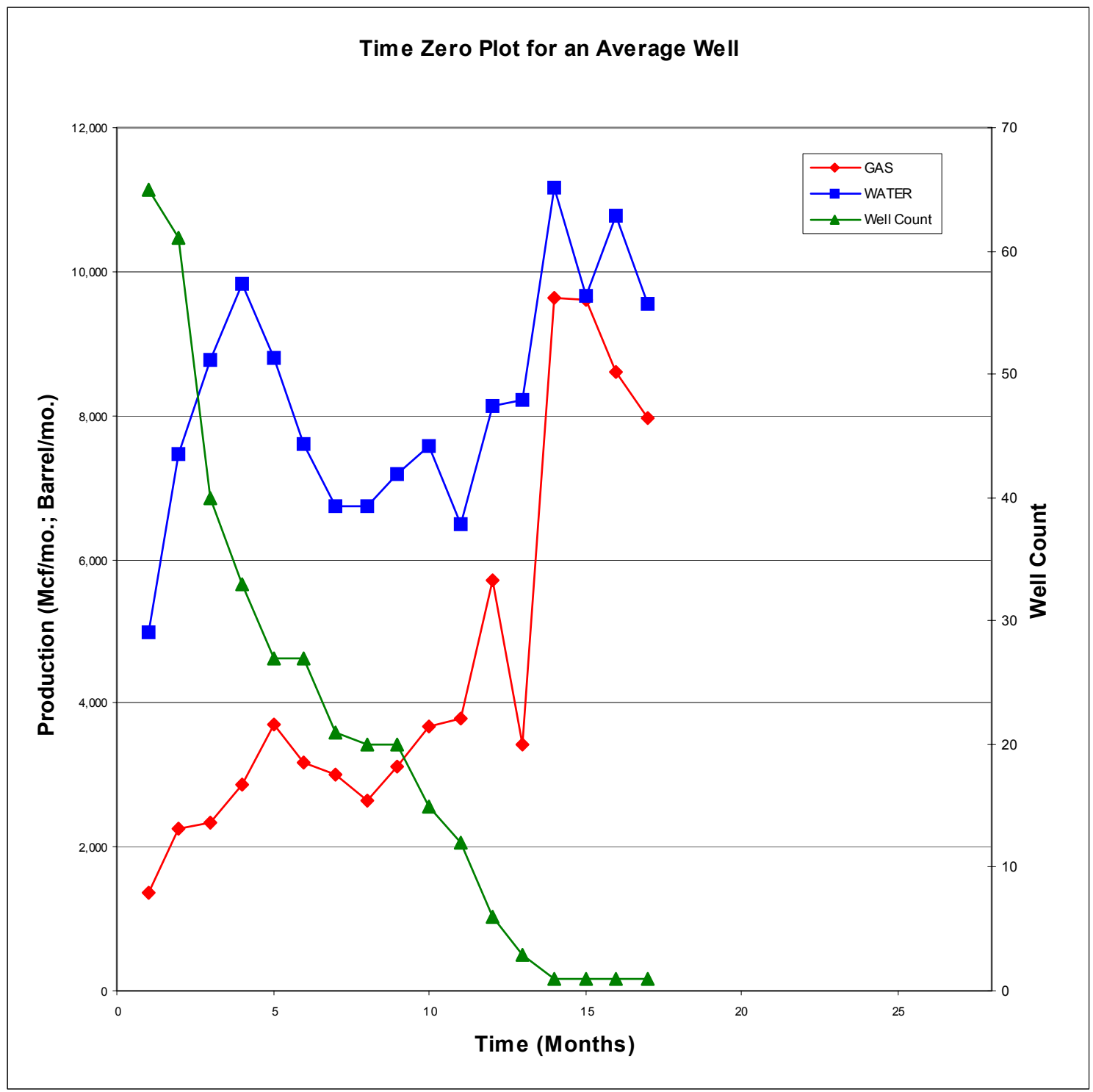

Figure 6-57. Carney (Cook) Time Zero Plot 


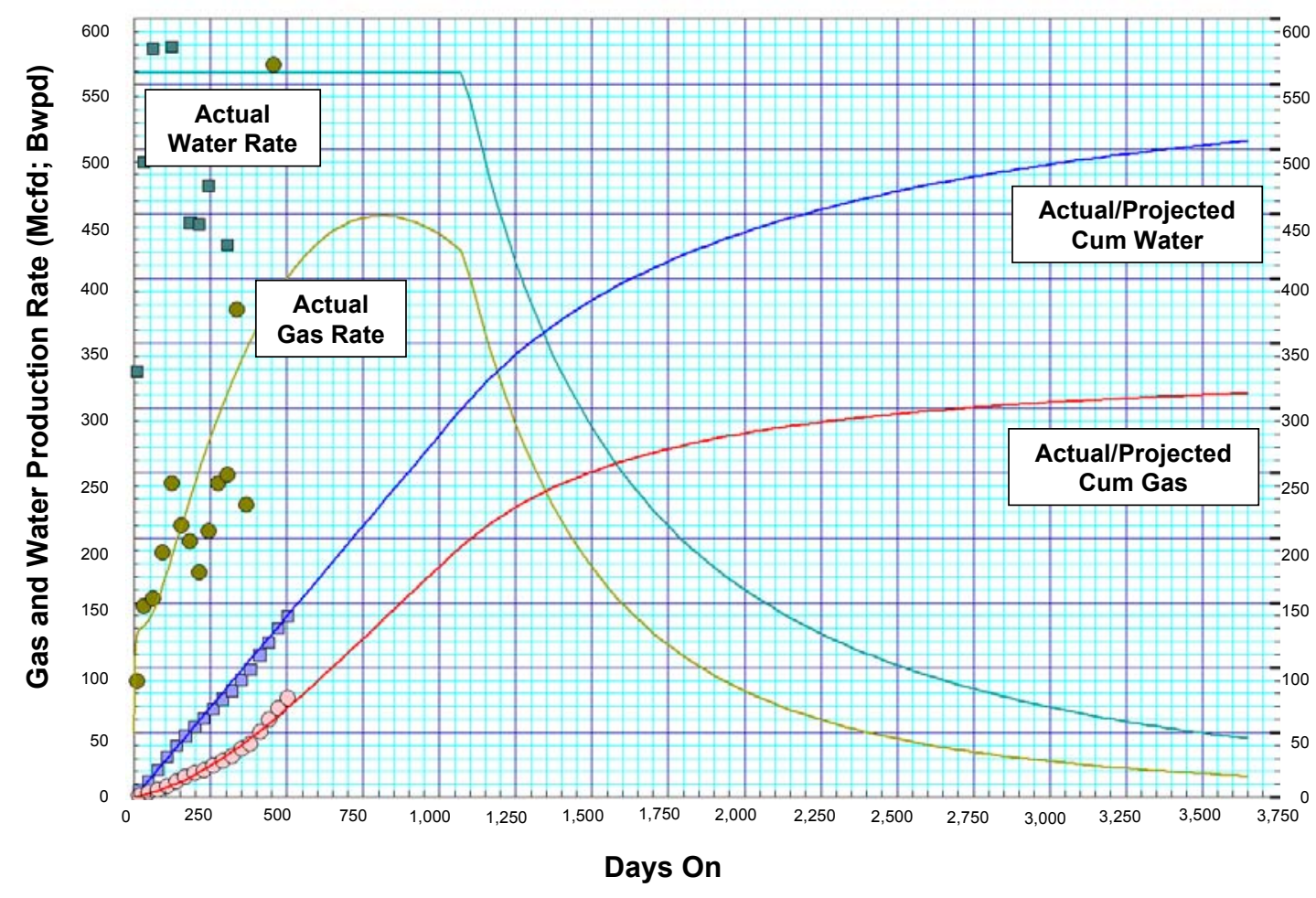

Figure 6-58. Carney (Cook), Partition \#11 


\section{APPENDIX A}

\section{GAS SORPTION CAPACITY AND GAS CONTENT FOR POWDER RIVER BASIN COALS}

\section{INTRODUCTION}

Considerable differences of opinion surround two closely related issues of importance to the outlook for coalbed methane in the Powder River Basin:

- $\quad$ First, what is the correct sorption (storage) capacity of the low rank PRB coals, and how does this sorption capacity change by coal depth and coal seam?

- $\quad$ Second, what is the actual (in situ) gas content in these coals, and are the PRB coals essentially fully saturated or undersaturated with gas?

Attempts to conclusively answer these two questions in the past have been impeded by the high permeability in the coals, difficulties with conventional gas content measurement approaches, and the presence of much lower than normal pressure conditions in the shallow coals.

This memorandum provides the data and assumptions used by Advanced Resources to address these two issues for the Powder River Basin in the DOE/NETL report "Powder River CBM Development and Produced Water Management Study" (PRB Study) of November, 2002.

\section{SUMMARY OF ADVANCED RESOURCES DATA AND METHODOLOGY}

\section{Background}

Operators in the basin have struggled greatly with the issue of the gas content and the level of gas saturation in the coal. Early gas content data, gathered in the 1980 s, showed the shallow coals along the eastern portion of the PRB to hold little methane. This gas content data led to extremely low values for gas in place, considerably below the actual gas recovery volumes established by the producing CBM wells.

Further uncertainty was introduced by the significantly underpressured conditions of these shallow coals. For example, the Wyodak coal (in T47-48 R72) has a pressure gradient of 0.274 $\mathrm{psi} / \mathrm{ft}$, giving it a pressure of $163 \mathrm{psi}$ (at a depth of $541 \mathrm{ft}$ to top of coal with a coal thickness of $78 \mathrm{ft}$ ), approximately $35 \%$ less than a normal pressure of about $250 \mathrm{psi}$. This condition, plus the high water production and delay in the arrival of gas production in the initial sets of wells, led many to conclude that the coals were also undersaturated with gas. [As is further discussed below, high initial water production and delay in gas production was due to the high permeability of the coals and the immaturity of development (lack of sufficient numbers of bounded wells) in the basin.] 
These data and observations led many operators to conclude that the PRB coals were uneconomic, delaying industry's entry into the basin.

\section{Gas Content}

The Advanced Resources PRB Study assembled available gas content data and adsorption isotherms, appropriate for the low rank coals of the Powder River Basin, from the following sources:

- $\quad$ Past gas content data collected by the BLM and published gas content and isotherm data by industry and the USGS were used as a point of reference,

- Advanced Resources' own gas content and isotherm data collected for analogous low rank coals in other basins, and

- $\quad$ Verification of the gas content and isotherm data using history matching (with COMET3) of alternative isotherms against long-term (4+year) gas and water production data in the PRB.

The best fit coalbed methane isotherm was from actual gas content and isotherm data collected on an analogous overseas low rank coal basin. Advanced Resources was the on-site field service contractor for the gas content measurement for these coals and used Terra Tek (in our view one of the most consistent, high quality CBM labs) for the adsorption isotherm (sorption capacity). The moisture content, volatile matter and fixed carbon content of the overseas low rank coal and the PRB Wyodak coal were similar as shown on Table A-1.

Table A-1. Comparison PRB Wyodak Coal and Overseas Low Rank Coal

\begin{tabular}{|c|c|c|c|}
\hline & \multicolumn{2}{|c|}{$\begin{array}{l}\text { PRB Wyodak Coal * } \\
\text { (59 Analyses) }\end{array}$} & \multirow[t]{2}{*}{$\begin{array}{l}\text { Overseas Low } \\
\text { Rank Coal ** }\end{array}$} \\
\hline & Average & Range & \\
\hline Rank & \multicolumn{2}{|c|}{ Lignite/Sub-bituminous } & Lignite/Sub-bituminous \\
\hline Fixed Carbon & $33.5 \%$ & $30-41 \%$ & $32.4 \%$ \\
\hline Volatile Matter & $30.7 \%$ & $26-33 \%$ & $44.6 \%$ \\
\hline Moisture Content & $29.8 \%$ & $23-37 \%$ & $23.0 \%$ *** \\
\hline Ash & $6 \%$ & $3-12 \%$ & $11 \%$ \\
\hline Heating Value (Btu/lb) & 8,224 & $7,420-9,310$ & 7,440 \\
\hline
\end{tabular}

* Source: Breckenridge, et al, (1974)

** Source: Advanced Resources Int'l, Inc. (1995)

${ }^{* * *}$ Moisture at $96 \% \mathrm{RH}$ and $40^{\circ} \mathrm{C}$

Figure A-1 provides the gas content isotherm used in the study of Powder River Basin coalbed methane. As a point of comparison, Figure A-2 provides the average synthesized adsorption isotherm for coal in the PRB assembled by the Wyoming BLM from earlier data. 


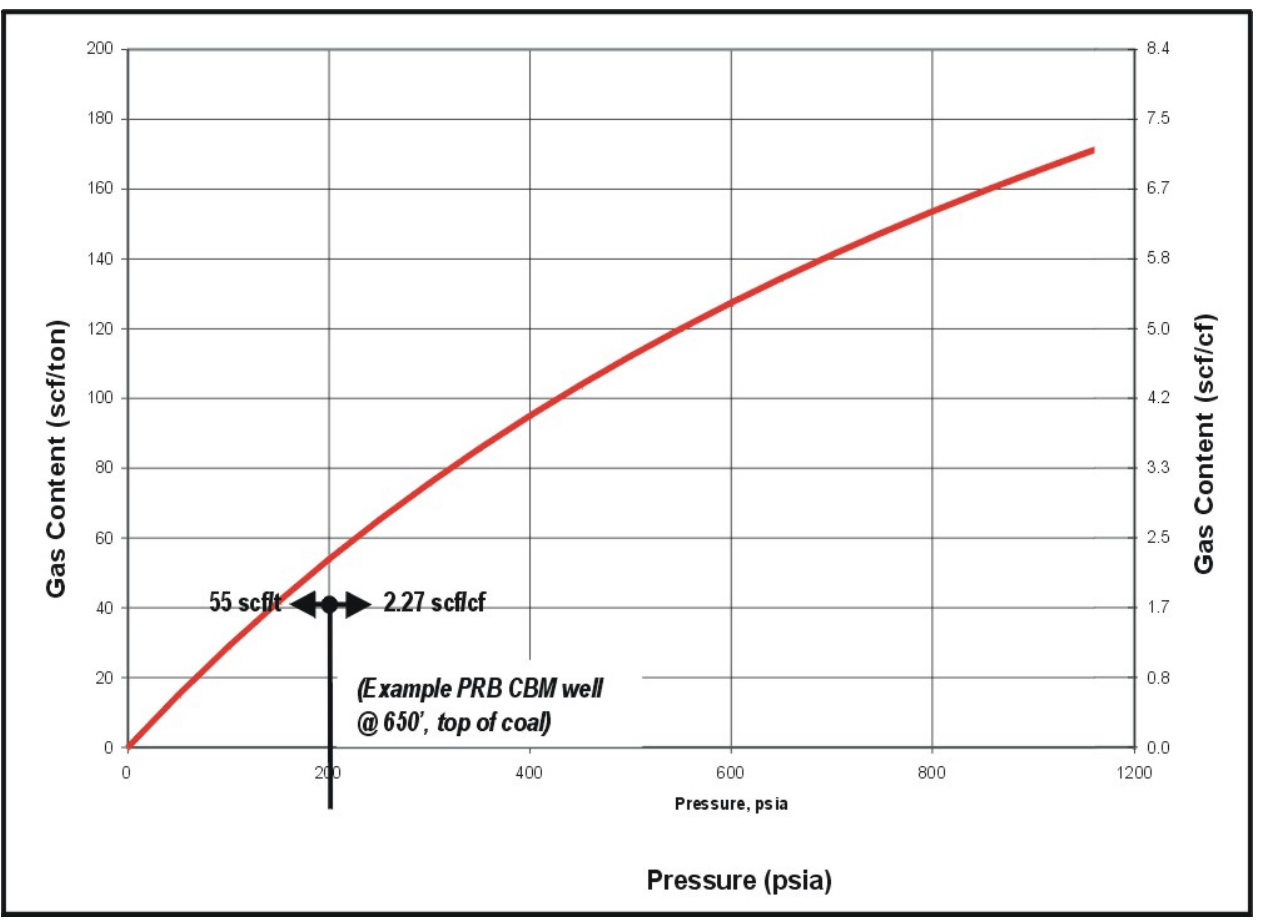

Figure A-1. Gas Content Isotherm Used for Powder River Coalbed Methane

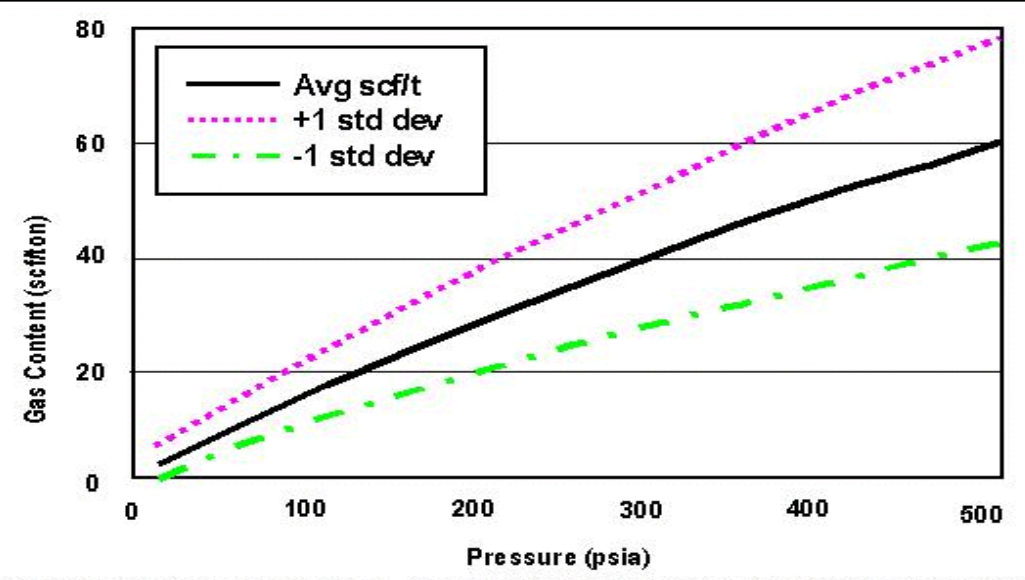

Source: From Wyoming EIS support documents. Average synthesized adsorption is otherm for 41 coal sampies from the PRB, bas ed on a compiation of data from public and private sources.

Figure A-2. Average Synthesized Adsorption Isotherm for 41 Coal Samples From the PRB, Based on a Compilation of Data From Public and Private Sources 


\section{Free Gas Saturation}

The nature of actual early time water and gas production from producing CBM wells in the basin was used to establish whether the PRB coals were undersaturated, fully saturated or contained free gas in the pore space:

- $\quad$ Gas and water production data were assembled and compiled for over selected 1,400 PRB CBM wells.

- Observation of production data from these 1,400 wells and history matching (with COMET3) of this production data was used to establish that the coals were (in general) fully gas saturated and, for certain seams, had free gas in the coal cleat and matrix system.

Based on this work, the PRB Study established that modest amounts of free gas exist in the coal cleat (fracture) and matrix porosity system for the shallower coal seams.

\section{FINDINGS BY OTHER INVESTIGATORS}

\section{Bustin and Downey}

The most recent, publicly available data on gas sorption and content for the Powder River Basin was presented by Bustin and Downey on the Dietz \#3 (Anderson equivalent) coal in the northwestern portion of the PRB. Their work on the sorption capacity of the Dietz \#3 coal (as a function of temperature and pressure) is provided in Figure A-3. The $20^{\circ} \mathrm{C}$ sorption capacity line would be reasonably representative of the upper Tongue River coals in the PRB.

A. Sorption Capacity. The Sorption Capacity Isotherm used in the Advanced Resources Study is compared with the sorption isotherm of Bustin and Downey in Figure A-4, with the vertical scale enlarged for easier comparison. The overlay of the data shows that the Advanced Resources Sorption Capacity Isotherm for PRB coals is somewhat lower than the $20^{\circ} \mathrm{C}$ Sorption Capacity Isotherm of Bustin and Downey for the Dietz \#3 coal.

B. Gas Content and Saturation. In the same paper, Bustin and Downey provide a series of observations with respect to the gas content and gas saturation conditions for the coals in the PRB. (Note that when coals are saturated and/or have free gas, the gas content value is the same as the value on the Sorption Capacity Isotherm. And, it is not physically possible to have free gas and undersaturated coals at the same time). Bustin and Downey wrote:

"There have been some 12,000 coalbed methane gas wells in the Powder River Basin to date, to produce methane gas from Eocene Fort Union Formation coal seams. Most have targeted the thick Wyodak coal seam(s) along the eastern flank of the basin where the coals are saturated and/or have free gas. ... " 


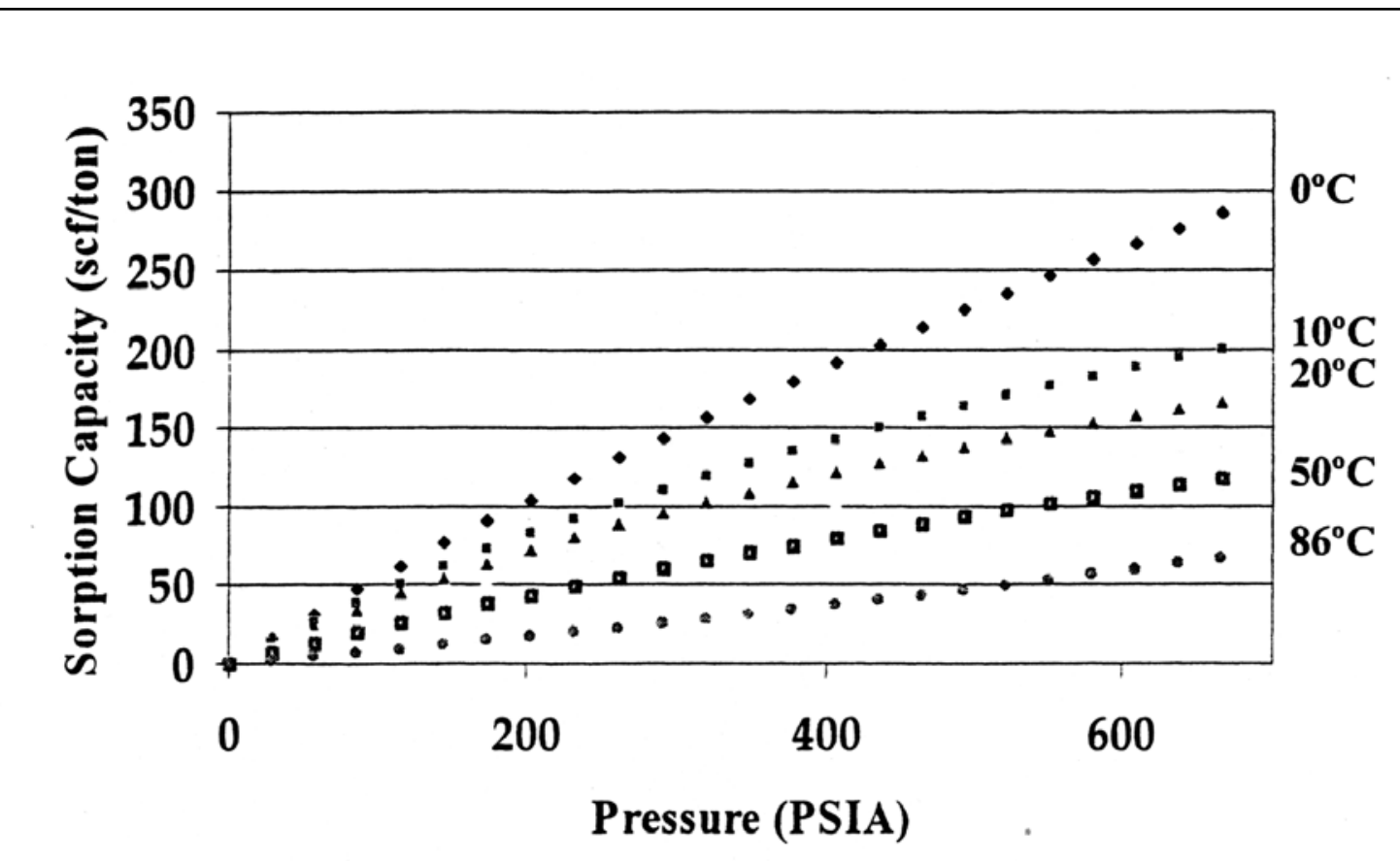

Source: Bustin and Downey (2002)

Figure A-3. Variation in Sorption Capacity with Temperature, Dietz \#3 Coal

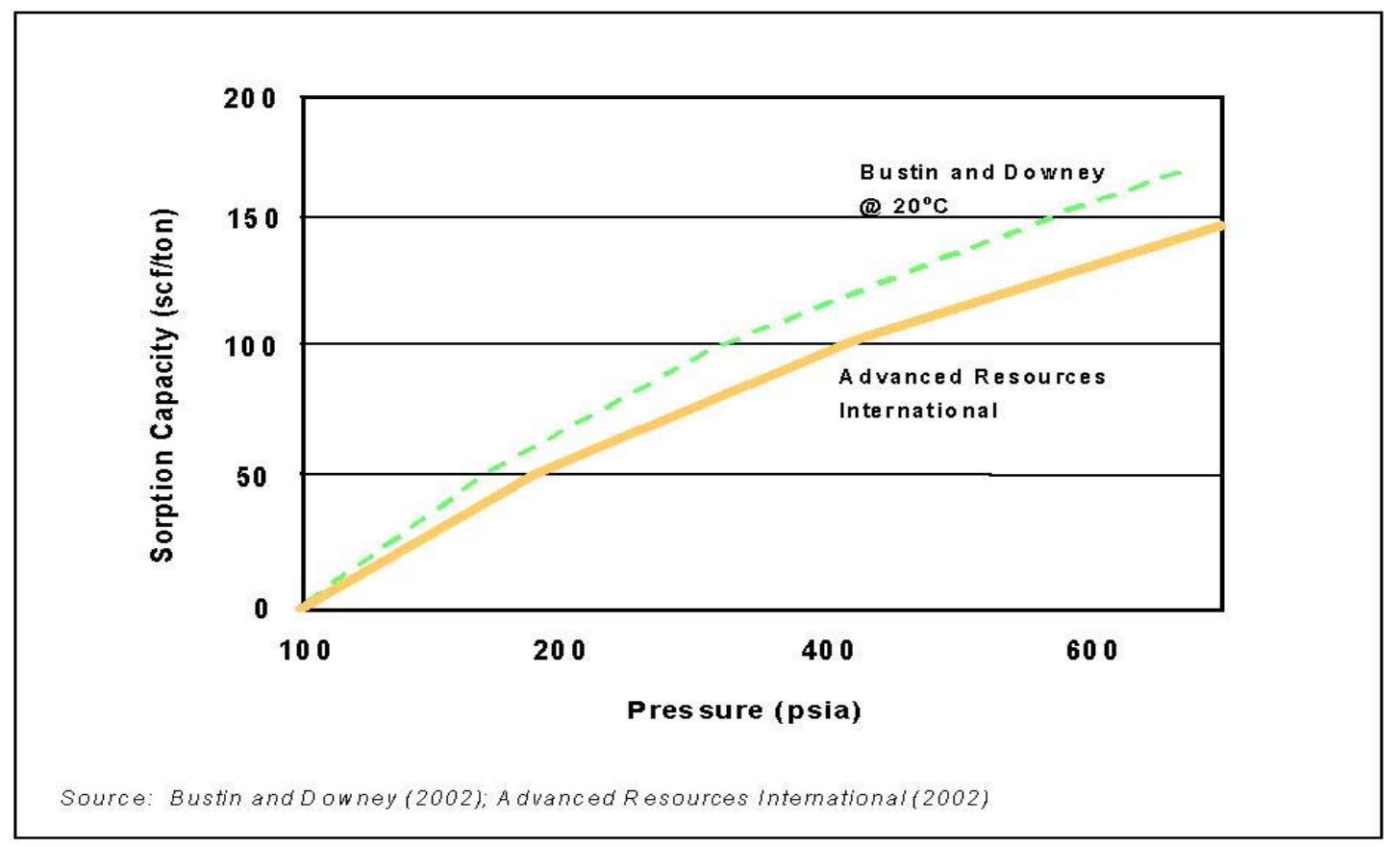

Figure A-4. Comparison of Bustin and Downey Adsorption Isotherm for Dietz \#3 Coal with Advanced Resources Adsorption Isotherm for PRB Coals 
"Free gas in coals is predicted wherever structural closure and uplift can be demonstrated. If the coals have been substantially uplifted, desorbed gas may partially flush the fractures resulting in lower water saturations. Near one of the coal mines on the east side of the Powder River Basin, coal seam gas contents and isotherm data, correlate very well and suggest the Wyodak coal is saturated at current pressure conditions although the gas content is markedly depleted as a result of depressurization."

However, Bustin and Downey do state that they have observed that "some of the deeper coal seams, such as the Cache and Pawnee, may be void of methane in some areas", particularly in areas south of Gillette, while "these coals appear to contain (and produce) methane in areas north of Gillette."

\section{Empirical Observations of Production Data}

A. Basic Mechanisms. The production profile for a typical coalbed methane well is high initial water production with little to no gas production. As the water rate declines and the reservoir pressure decreases, gas is desorbed from the coal, moves through the coal matrix by diffusion and through the coal cleat system by Darcy flow to the production well. The need to establish a critical gas saturation and overcome the low initial relative permeability to gas further delay the arrival of the released methane in the production well.

Depending on reservoir and development conditions (and assuming no free gas), it may take 3 months to a year (or longer) to observe significant rates of gas production.

B. Evidence of Free Gas and Fully Saturated Coals. The early production of gas, as demonstrated by the 164 Wyodak coal wells drilled in the mid-1990s in T47-48N, R72W, Figure A-5, can only be explained by the presence of free gas. Advanced Resources reservoir simulation-based history matching of this set of wells, indicates the presence of $10 \%$ free gas in the matrix porosity and $5 \%$ free gas in the cleat system, Figure A- 6 .

To examine the difference that the presence or absence of free gas has on gas production rates and recovery, we set the free gas values to zero in our next simulation run, while helping other reservoir properties the same. The resulting production curve clearly shows that gas production is much lower and later than has actually occurred, Figure A-7.

Finally, we examine how the Wyodak coal wells would produce in this area if they were $23 \%$ to $66 \%$ undersaturated. The use of such extreme gas undersaturation values for the Wyodak coal provides a gas production curve that is many-fold lower than actually observed, making this coal essentially non-productive, as shown on Figures A-8 and A-9.

\footnotetext{
1“'Gas-in-place in the Powder River Basin: Coal Core - Why Do Them? Some Field Results, Comparisons, and Suggestion”, R. Marc Bustin, the University of British Columbia, Vancouver, and Rover A. Downey, Energy Ingenuity Company, RMAG PTTC GTI 2002 Coalbed Methane Symposium, June 19, 2002.
} 


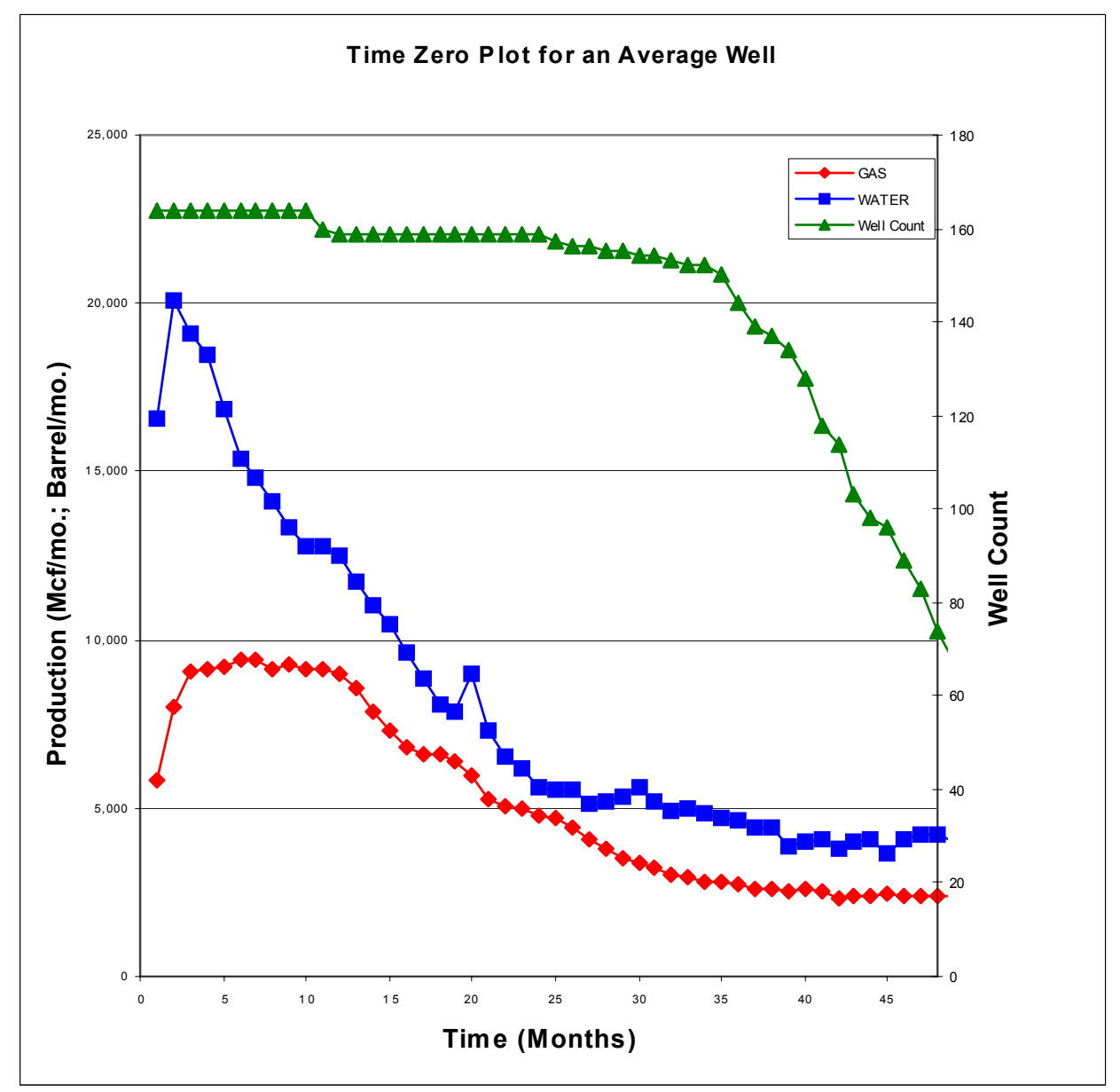

Figure A-5. Wyodak Time Zero Well Data

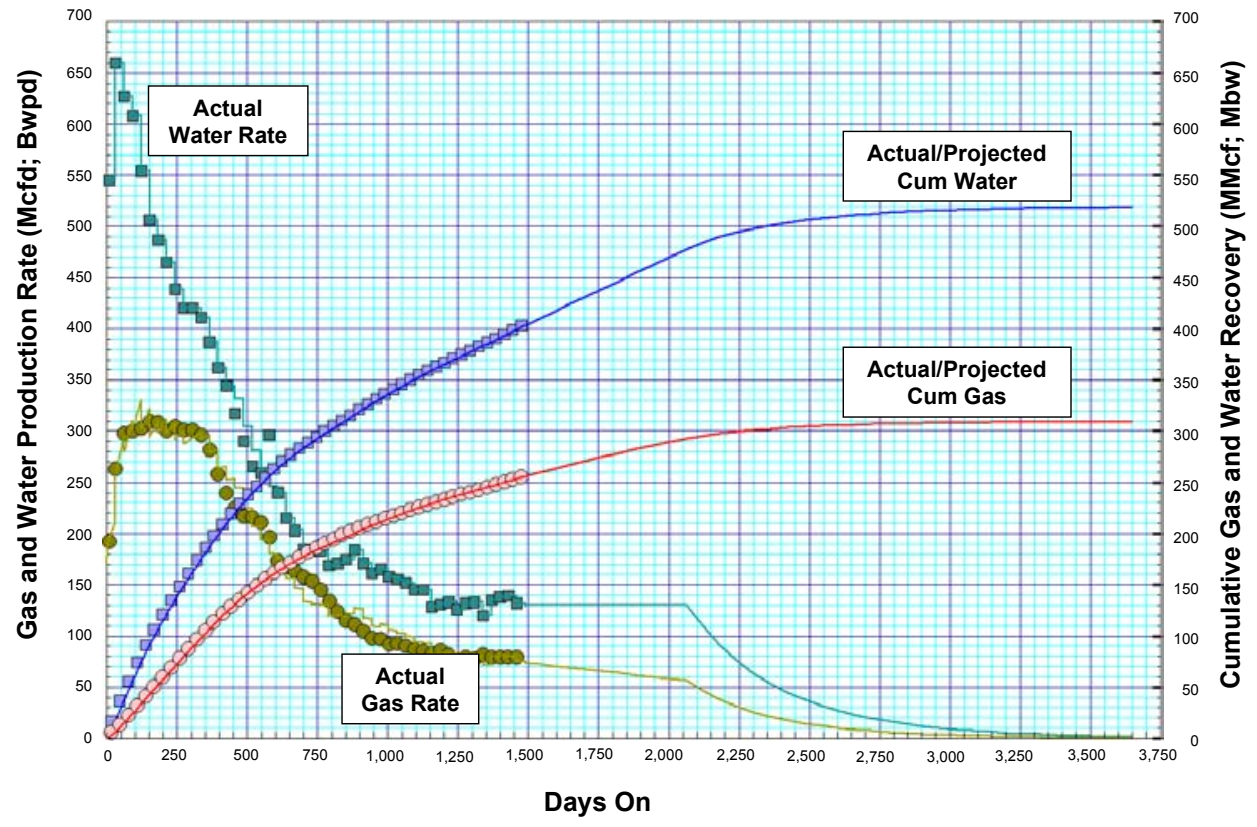

Figure A-6. History Match Wyodak Type Well w/ Free Gas 


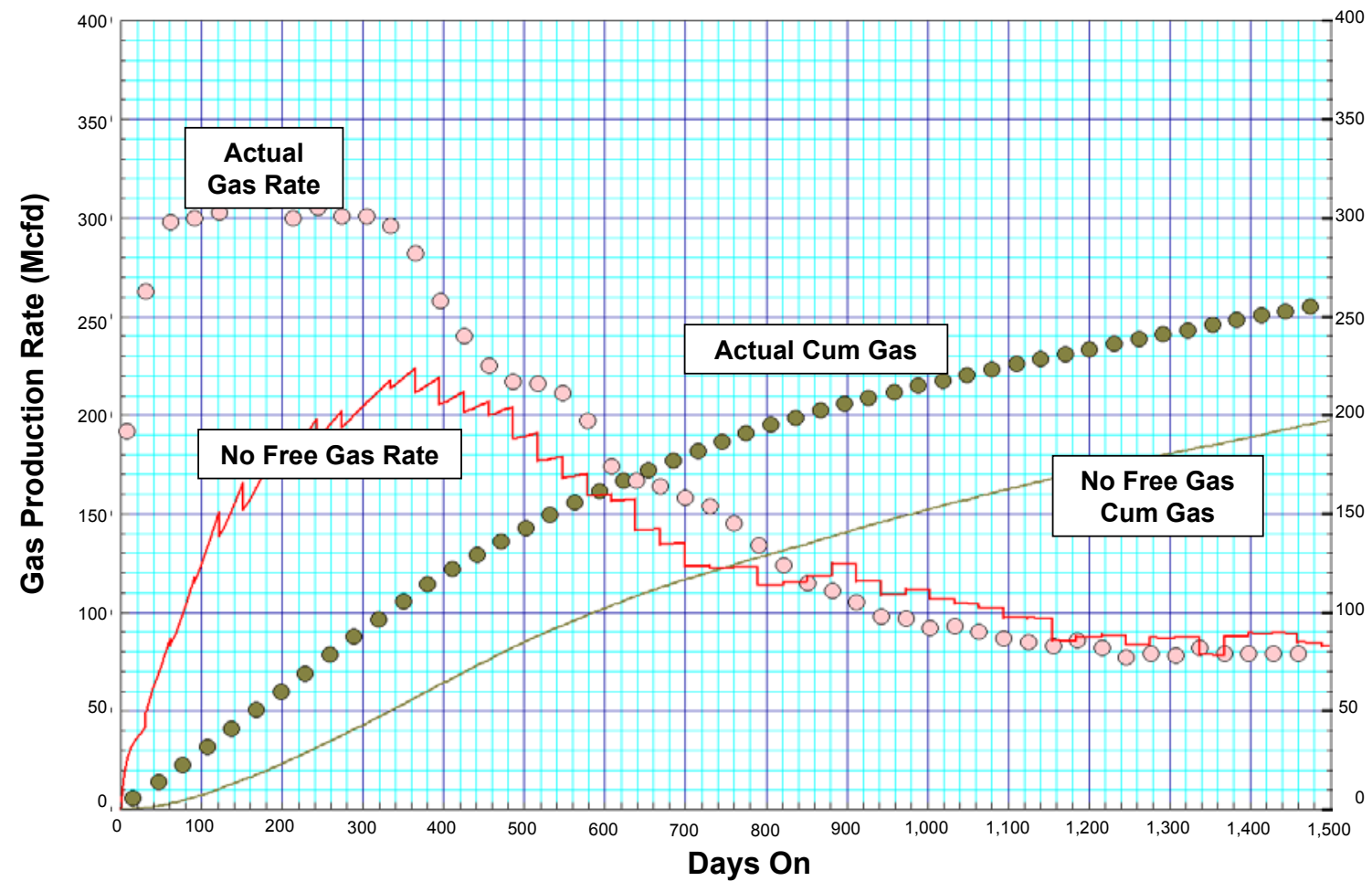

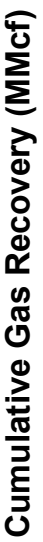

Figure A-7. Reservoir Simulation of Wyodak Type Well w/ No Free Gas

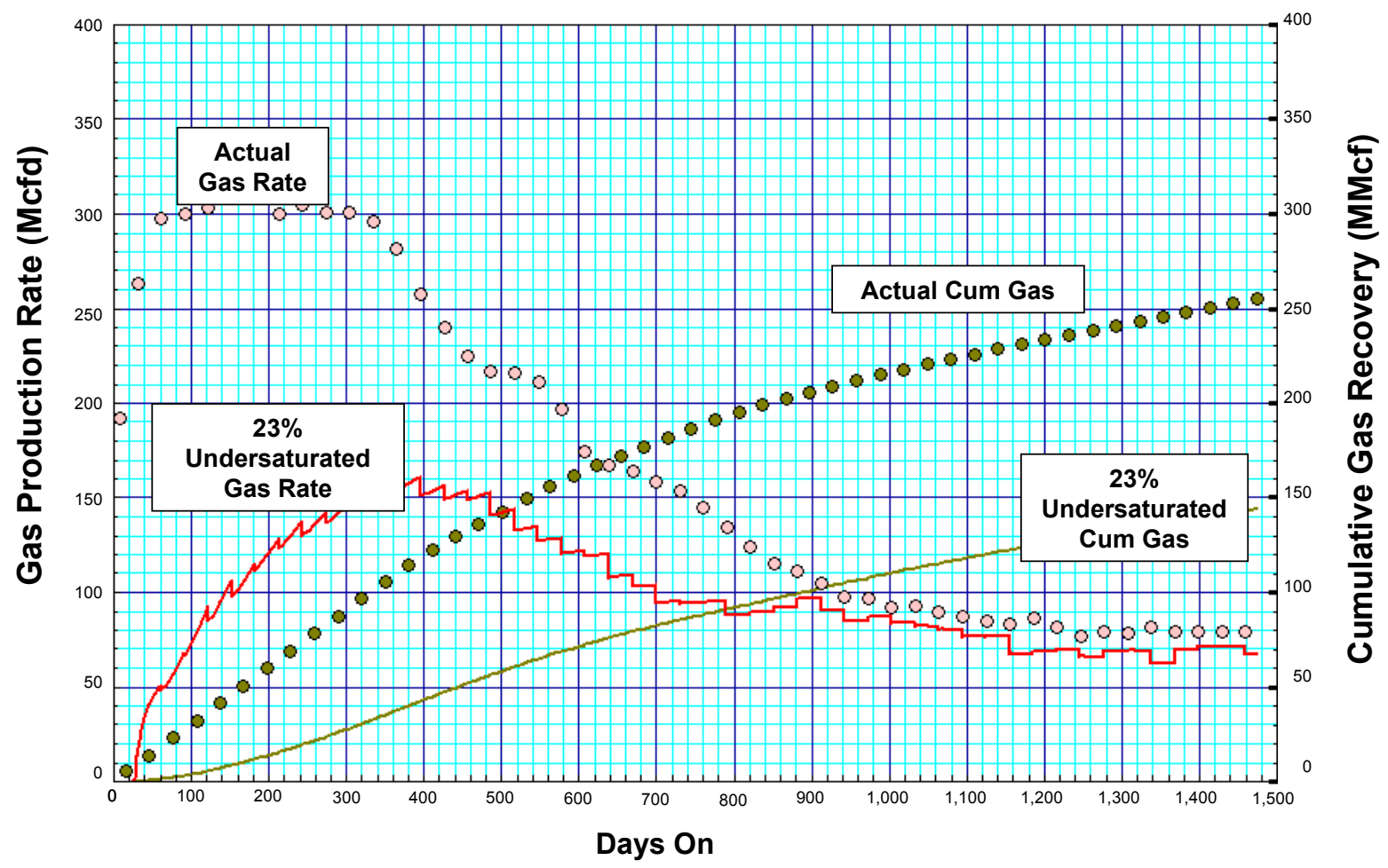

Figure A-8. Reservoir Simulation of Wyodak Type Well w/ 23\% Gas Undersaturation 


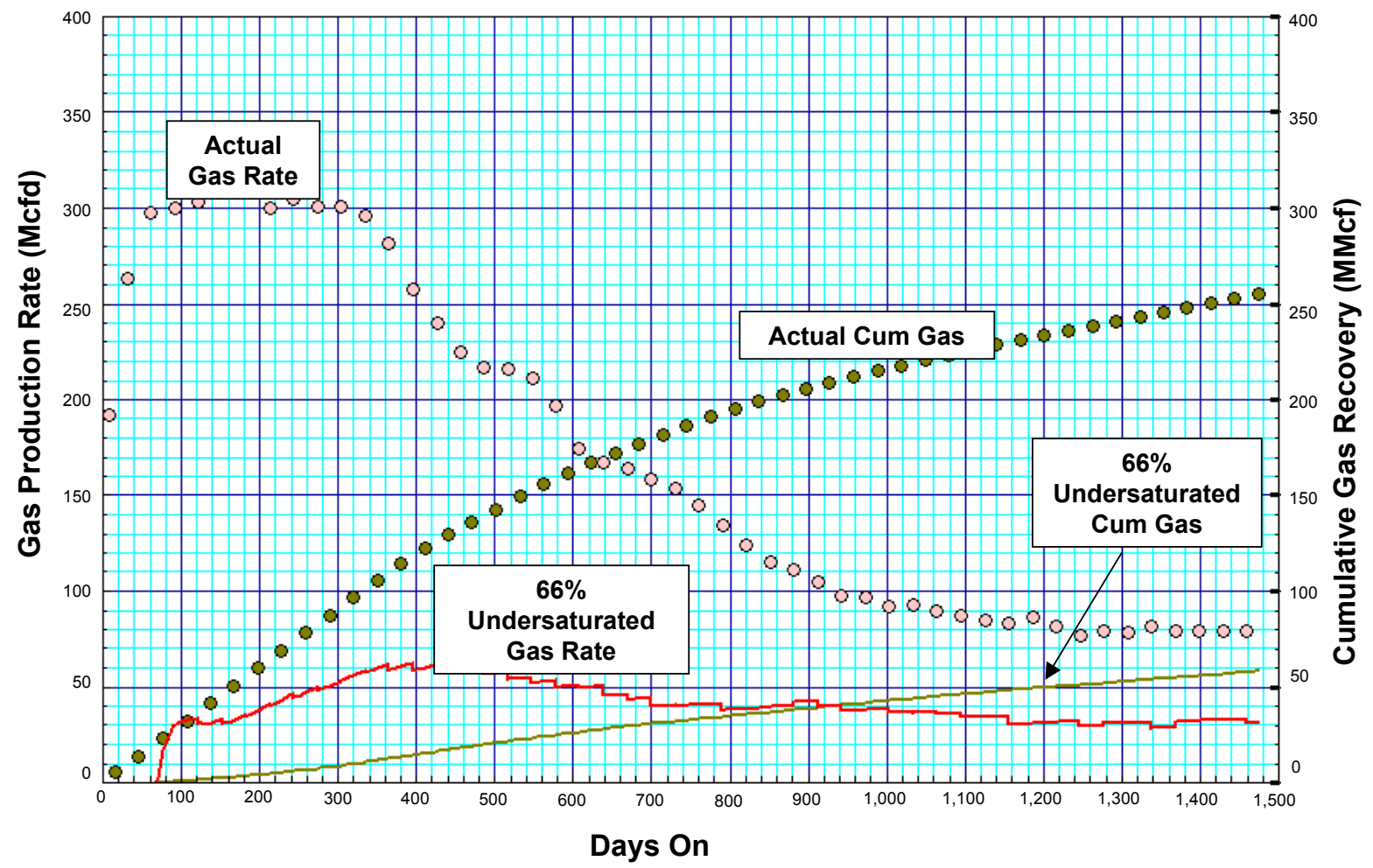

Figure A-9. Reservoir Simulation of Wyodak Type Well w/ 66\% Gas Undersaturation

Table A-2 provides a comparison of the results from reservoir modeling of the four gas saturation cases against actual production data.

Table A-2. Comparison of Gas Production Rates for Wyodak Type Well

\begin{tabular}{|c|c|c|c|c|c|}
\hline & \multirow{3}{*}{$\begin{array}{l}\text { Actual } \\
\text { Data }\end{array}$} & \multicolumn{4}{|c|}{ Reservoir Simulation Output } \\
\hline & & \multicolumn{2}{|c|}{ Fully Saturated } & \multicolumn{2}{|c|}{ Undersaturated } \\
\hline & & w/Free Gas & w/No Free Gas & $23 \%$ & $66 \%$ \\
\hline \multicolumn{6}{|c|}{ Gas Rate (Mcfd) } \\
\hline @ 46 days & 263 & 276 & 69 & 41 & 0 \\
\hline @ 289 days & 301 & 291 & 200 & 142 & 51 \\
\hline \multicolumn{6}{|c|}{ Cumulative Gas Recovery (MMcf) } \\
\hline$@ 1,475$ days & 255 & 255 & 196 & 144 & 58 \\
\hline
\end{tabular}

Table A-3 provides data on key reservoir properties, such as coal seam depth, gas content, pressure, and porosity used in the history match and sensitivity cases for the Wyodak coals discussed in this memo. 
Table A-3. Wyodak Coal Seam Properties

\begin{tabular}{|c|c|c|c|c|c|c|}
\hline \multirow{2}{*}{$\begin{array}{c}\text { Coal } \\
\text { Seam }\end{array}$} & & \multirow{2}{*}{$\begin{array}{c}\text { Gas } \\
\text { Seath }\end{array}$} & Pressure & \multirow{2}{*}{$\begin{array}{c}\text { Pressure } \\
\text { Gradient }\end{array}$} & $\begin{array}{c}|c| \\
\text { Coal) }\end{array}$ & Forosity \\
\cline { 5 - 8 } & (feet) & (cf/t) & (psi/ft) & (psi) & (\%) & (\%) \\
\hline $\begin{array}{l}\text { Wyodak } \\
\text { (Partition \#4) }\end{array}$ & 541 & 65 & 0.274 & 163 & 1.0 & 6.0 \\
\hline
\end{tabular}

\section{Evidence for Undersaturated Coals}

No doubt undersaturated coals exist for some of the coal seams in some portions of the basin, as discussed earlier by Bustin and Downey. Even in the Warrior Basin, some pockets of low gas saturation have been observed in seams where the coals have been breached by faults.

However, high early water production and a delay in gas production (accepted as normal in most other coal basins of the world) are not necessarily evidence that the coals are undersaturated. To examine this, we assembled data on a group of 38 Big George coal wells in a deep, immaturely developed portion of the basin. The time-zero gas and water production curve for these wells is provided in Figure A-10. The reservoir simulation history match for these wells showed that the coals were fully gas saturated (but with no free gas) and that the delayed onset of gas production was caused by the difficulties in drawing down reservoir pressure due to high permeability and the unconfined nature of the wells, Figure A-11.

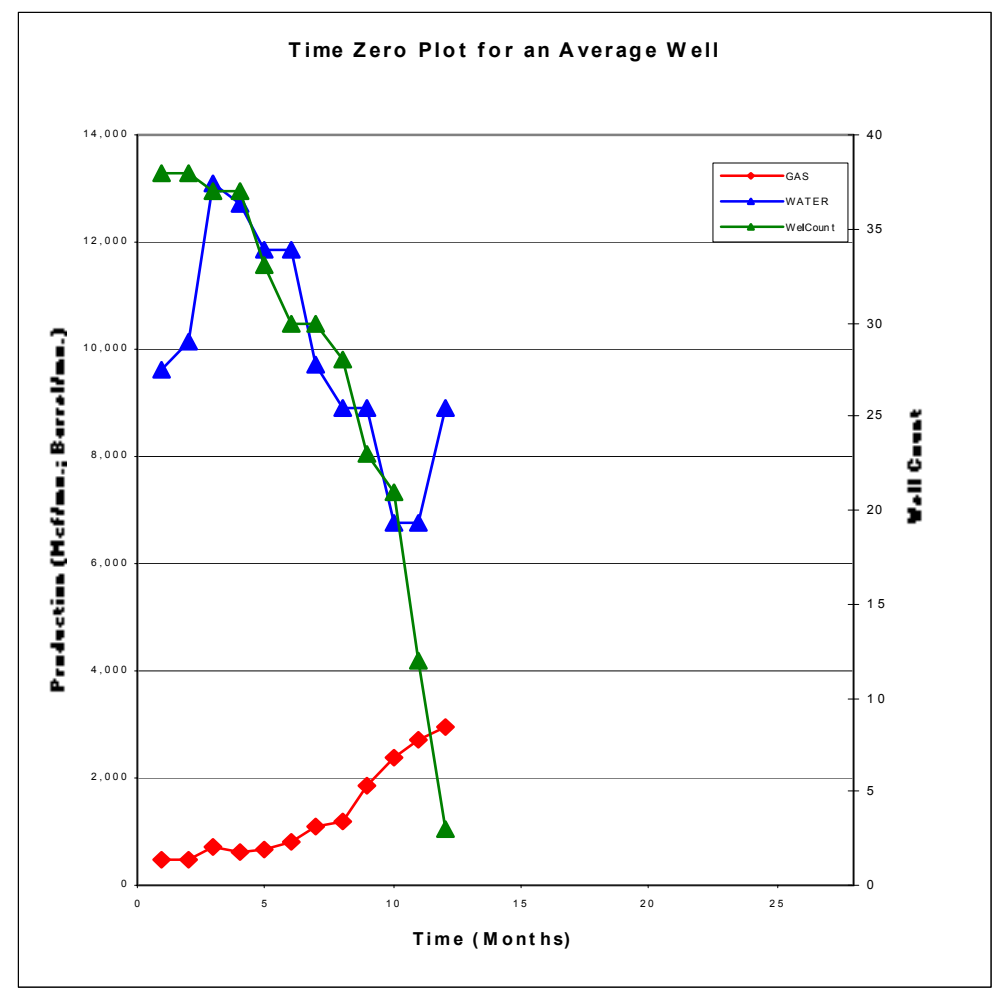

Figure A-10. Big George Time Zero Well Data 


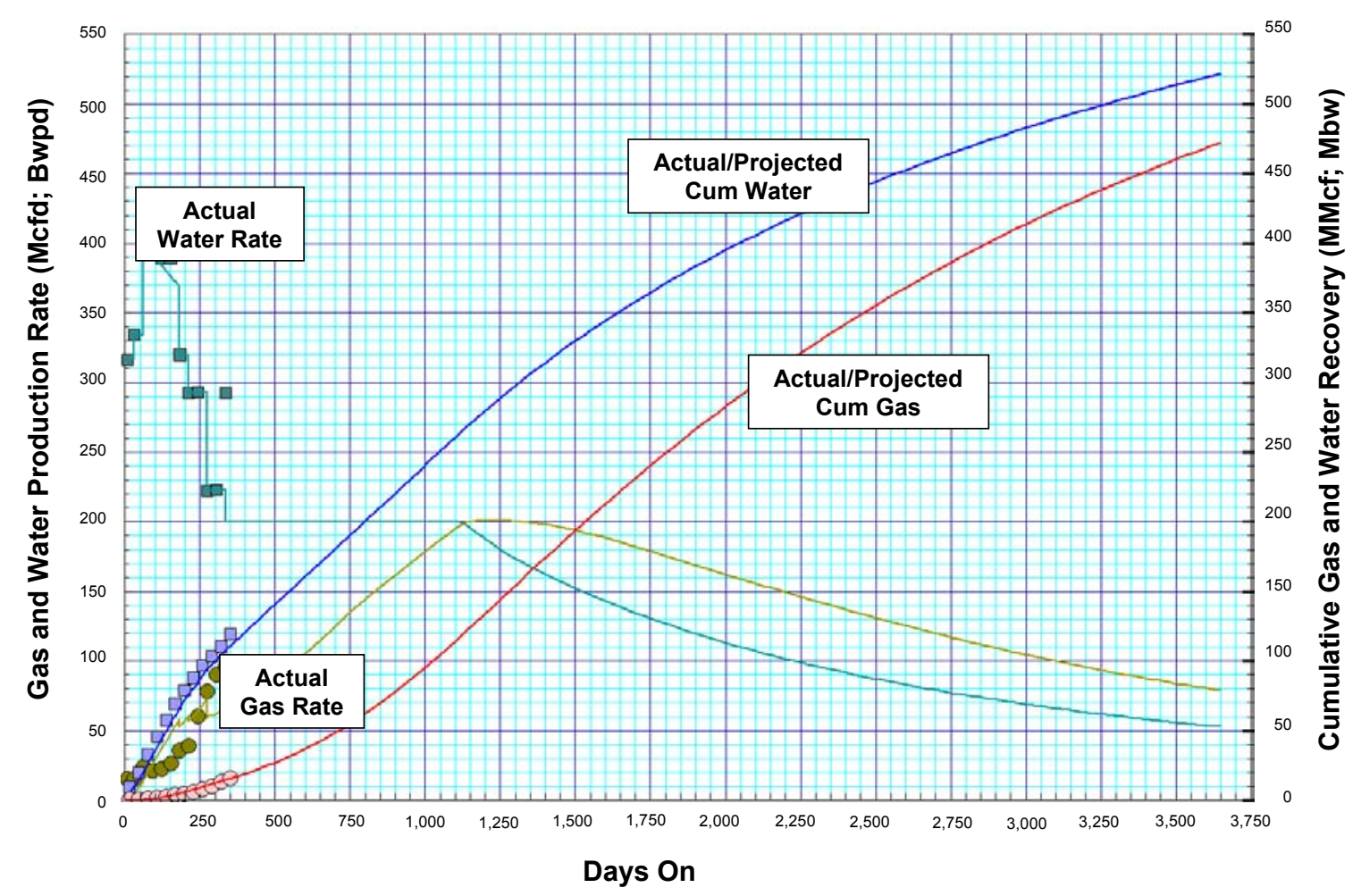

Figure A-11. History Match Big George Type Well

As for the Wyodak, we examined how the Big George coal wells in this area would produce if they were $23 \%$ to $66 \%$ undersaturated. Again, the use of such extreme gas undersaturation values for the Big George coal provides gas production and recovery values that are much lower than actually observed, as shown in Figure A-12 for the 23\% gas undersaturated case. (No gas production occurs from the Big George coal for the $66 \%$ undersaturated case during the first year).

Table A-4 provides a comparison of the results from reservoir modeling of the three gas saturation cases against actual production data.

Table A-4. Comparison of Gas Production Rates for Big George Type Well

\begin{tabular}{|c|c|c|c|c|}
\hline & \multirow{3}{*}{$\begin{array}{l}\text { Actual } \\
\text { Data }\end{array}$} & \multicolumn{3}{|c|}{ Reservoir Simulation Output } \\
\hline & & \multirow{2}{*}{$\begin{array}{l}\text { Fully Saturated } \\
\text { w/No Free Gas }\end{array}$} & \multicolumn{2}{|c|}{ Undersaturated } \\
\hline & & & $23 \%$ & $66 \%$ \\
\hline \multicolumn{5}{|c|}{ Gas Production (Mcfd) } \\
\hline$@ 76$ days & & 21 & 0 & ( \\
\hline @ 289 days & & 61 & 20 & ( \\
\hline
\end{tabular}




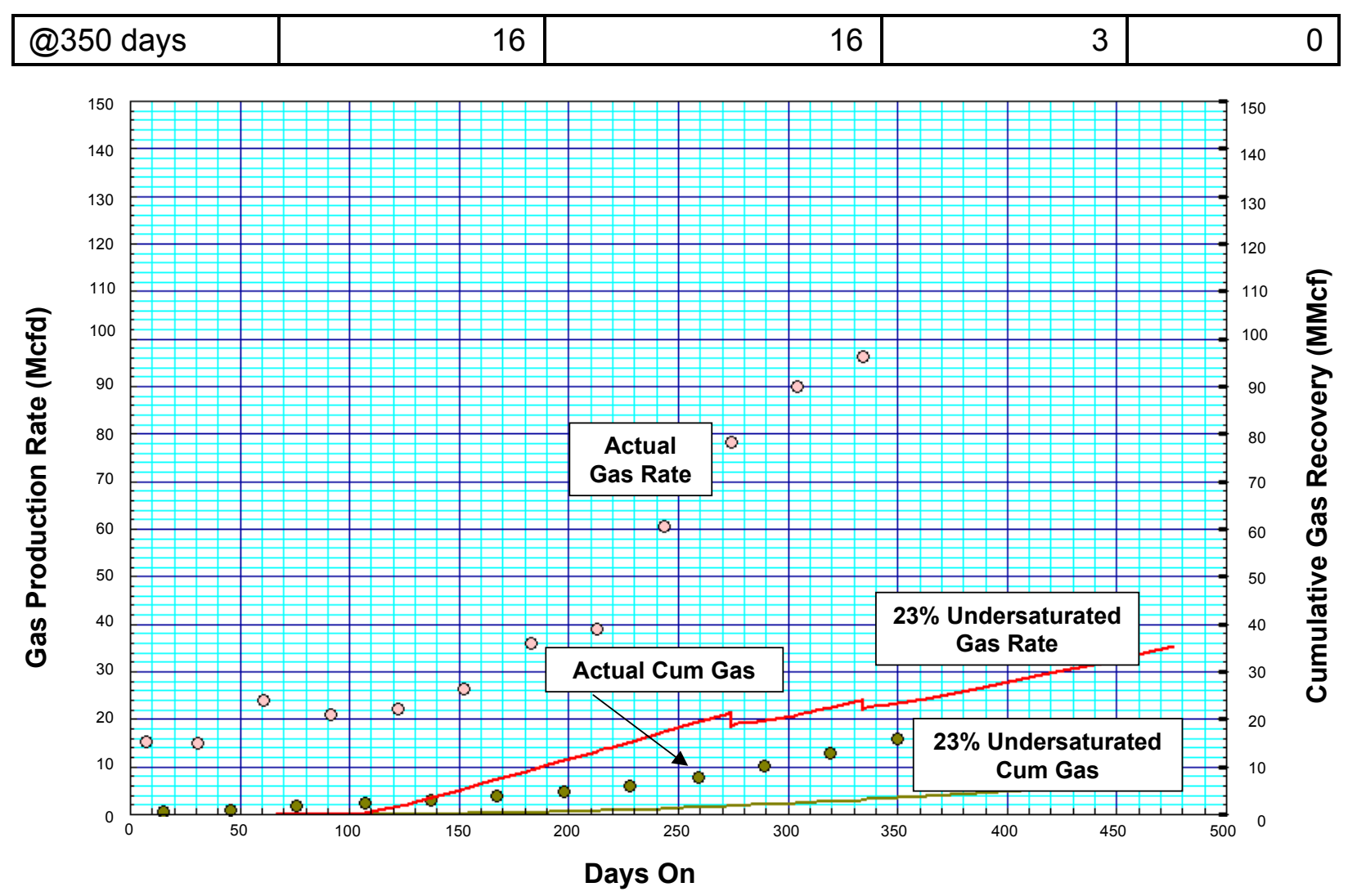

Figure A-12. Reservoir Simulation of Big George Type Well w/23\% Gas Undersaturation

Table A-5 provides the data on key reservoir properties, such as coal seam depth, gas content, pressure, and porosity used in the history match and sensitivity cases for the Big George coal discussed in the memo.

Table A-5. Big George Coal Seam Properties

\begin{tabular}{|c|c|c|c|c|c|c|}
\hline \multirow{2}{*}{$\begin{array}{c}\text { Coal } \\
\text { Seam }\end{array}$} & Depth & \multirow{2}{*}{$\begin{array}{c}\text { Gas } \\
\text { Content }\end{array}$} & $\begin{array}{c}\text { Pressure } \\
\text { Gradient }\end{array}$ & $\begin{array}{c}\text { Pressure } \\
\text { (Top of } \\
\text { Coal) }\end{array}$ & \multicolumn{2}{|c|}{ Porosity } \\
\cline { 4 - 7 } & (feet) & (cf/t) & (psi/ft) & (psi) & (\%) & (\%) \\
\hline $\begin{array}{l}\text { Big George } \\
\text { (Partition \#3) }\end{array}$ & 1,000 & 86 & 0.320 & 335 & 0.2 & 4.0 \\
\hline
\end{tabular}

\section{OTHER STUDIES}

The 1995 USGS National Assessment included estimates for coalbed methane in the Powder River Basin. Dudley Rice, of the USGS, collected the geologic and reservoir data and Advanced Resources conducted the reservoir simulations to establish recoverable gas. This past assessment included the following data for the coals in the PRB, Table A-6: 
- The shallow coals were assumed to be fully gas saturated (desorption pressure equals reservoir pressure); the deep coals were assumed to be $86 \%$ gas saturated.

- The gas content for the shallow coals (at 500 feet and 165 psi) was calculated at 60 scf/ton; the gas content for the deep coals (at 1,250 feet and 490 psi) was calculated at $126 \mathrm{scf} / \mathrm{ton}$.

- The shallow coals were assumed to have 30\% free gas in the fracture system; the deep coals were assumed to have no free gas.

Table A-6. Reservoir Parameters for Powder River Basin (Fort Union Coals)

\begin{tabular}{|c|c|c|}
\hline & Shallow & Deep \\
\hline Coal Depth, feet & 500 & 1,250 \\
\hline Coal Thickness, feet & 90 & 90 \\
\hline Pressure Gradient, $\mathrm{psi} / \mathrm{ft}$ & 0.30 & 0.38 \\
\hline Initial Reservoir Pressure, psia & 165 & 490 \\
\hline Initial Water (Gas) Saturation, \% & $70(30)$ & $100(0)$ \\
\hline In Situ Langmuir Volume, scf/ton ${ }^{a}$ & 562 & 562 \\
\hline Langmuir Pressure, psia & 1,380 & 1,380 \\
\hline In Situ Gas Content, scf/ton ${ }^{\text {a }}$ & 60 & 126 \\
\hline Desorption Pressure, psia & 165 & $390^{\mathrm{b}}$ \\
\hline Sorption Time, days & 3 & 3 \\
\hline Reservoir Temperature, ${ }^{\circ} \mathrm{F}$ & 72 & 100 \\
\hline Cleat Porosity, \% & 4 & 2 \\
\hline Pore Volume Compressibility, $10^{-6} \mathrm{psi}^{-1}$ & 200 & 200 \\
\hline Cleat Spacing, inches & 0.2 & 0.2 \\
\hline Gas Gravity & 0.75 & 0.75 \\
\hline Water Viscosity at Reservoir Conditions, cp & 0.96 & 0.69 \\
\hline Water Formation Volume Factor, RB/STB & 1.01 & 1.01 \\
\hline Completion and Stimulation & $\begin{array}{c}\text { Open-hole/Cased \& } \\
\text { Frac'd }^{\text {c }}\end{array}$ & $\begin{array}{l}\text { Cased \& Frac'd } \\
\quad x f=40 \mathrm{ft}^{\mathrm{d}}\end{array}$ \\
\hline Well Operation & Pump Down Schedule & 150 bwpd Pump Rate \\
\hline Well Spacing, acres/well & 40 & 40 \\
\hline Aquifer Recharge Rate, bwpd & Weak (50), Strong (400) & None \\
\hline Absolute Cleat Permeability, md & $10,50,75$ & $1,5,10$ \\
\hline
\end{tabular}

a In situ conditons include $3 \%$ ash and $20 \%$ moisture

b Deeper coals are $86 \%$ saturated relative to the adsorptive capacity

c Both completion types yield similar performance; $r_{w}=0.26 \mathrm{ft}$ used in simulations with no skin factor applied

d Assumes infinite conductivity fracture half-length (xf) 
The comparison of gas content in the two studies, Table A-7 below, shows the PRB Study used somewhat lower gas content values for the PRB coals than those used in the 1995 USGS National Assessment.

Table A-7. Comparison of 1995 USGS and 2002 ARI Values for Gas Content of PRB Coals

\begin{tabular}{|l|c|c|c|c|}
\hline \multirow{2}{*}{} & \multicolumn{2}{|c|}{ Shallow Coal } & \multicolumn{2}{c|}{ Deep Coal } \\
\cline { 2 - 5 } & 1995 USGS & 2002 ARI & 1995 USGS & 2002 ARI \\
\hline Pressure (psi) & 165 & 165 & 490 & 490 \\
\hline Gas Content (cf/t) & 60 & 45 & 126 & 105 \\
\hline
\end{tabular}

